\title{
REVISIONS TO ROLAND BROWN'S NORTH AMERICAN PALEOCENE FLORA
}

\author{
STEVEN R. MANCHESTER \\ Florida Museum of Natural History, University of Florida, 1569 Museum Road, Gainesville, Florida 32611-7800, USA; e-mail: \\ steven@flmnh.ufl.edu
}

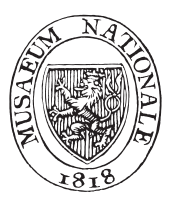

Manchester, S. R. (2014): Revisions to Roland Brown's North American Paleocene flora. - Acta Mus. Nat. Pragae, Ser. B, Hist. Nat., 70(3-4): 153-210, Praha. ISSN 1804-6479.

\begin{abstract}
The Paleocene megafossil flora of the Rocky Mountains and Great Plains region in the United States of America, including leaves, cones, fruits, and seeds, monographed by Roland W. Brown in 1962, has been reevaluated and updated to include subsequent taxonomic revisions. The scope of this investigation included thousands of specimens from more than 450 localities of the Fort Union, Evanston, Ferris, Raton, Bear, Lebo, Melville, Ludlow, Tongue River and Sentinel Butte strata of New Mexico, Colorado, Wyoming, Montana and North and South Dakota. A large number of floristic elements remain uncertain as to their modern familial affinities due to limited diagnostic characters, or insufficient comparative investigations. Nevertheless, many of Brown's determinations have been upheld and several newly recognized genera and families have strong support. The flora includes greater diversity of Platanaceae and Cornales than Brown had recognized. These, together with Fagales (particularly Betulaceae and Juglandaceae), Saxifragales (Trochodendroides, Archeampelos and Nyssidium), are widespread and prominent members of the flora. New combinations introduced here include Ensete goldianum (LESQUEREUX) comb. nov., Macginitiea nobilis (NEWBERRY) comb. nov., Platanites raynoldsii (NEWBERRY) comb. nov., Trochodendroides genetrix (NEWBERRY) comb nov., Cucurbitaciphyllum lobatum (KNOwLTON) comb. nov., and Mciveraephyllum nebrascense (SCHIMPER) comb. nov. Georeference data are provided for all of the localities cited by Brown.
\end{abstract}

angiosperms, conifers, ferns, fossil plants, leaves, Paleocene, Rocky Mountains, North America, systematics, taxonomy

Received October 7, 2014

Issued December 2014

\section{Introduction}

The monograph of Roland W. Brown (1962) stands as the most comprehensive treatment of the Paleocene flora of the Rocky Mountain and Great Plains region in the USA based on specimens from more than 450 localities scattered across New Mexico, Colorado, Wyoming, Montana, South Dakota, and North Dakota. In that treatment, he reexamined collections made earlier by Newberry (1898), Lesquereux (1878), Ward (1886, 1887), and Knowlton (1917, 1922, 1924, 1930), and reassessed affinities of the taxa and stratigraphic positions, augmented by many new sites that he had collected during the 1930s through 50s (Text-fig. 1). In the monograph, published posthumously, Brown described 35 new species and made several new combinations. Initially, these lacked designation of types and repository numbers, but this was rectified with the designation of lectotypes by Watt (1971).

Subsequent treatments, such as monographs of the Golden Valley (Hickey 1977) and Almont (Crane et al. 1990, Zetter et al. 2011) floras of North Dakota and the Ravenscrag flora in Saskatchewan (McIver and Basinger 1993) have expanded and augmented the regional flora, but the overview provided by Brown remains an essential guide to the diversity of North American Paleocene megafossil plants and their distribution patterns across the Rocky Mountain and Great Plains region during the Paleocene. This work has been useful to many authors of biostratigraphic and paleoecological investigations (e.g., Barclay et al. 2003, Ellis et al. 2003, Gemmill and Johnson 1997, Hickey 1980, Hoffman and Stockey 1999, Johnson 2002, Peppe 2010, Peppe and Hickey 2014, Stockey et al. 2013, 2014, Wilf 2002, Wilf et al. 1998, Wing, 1998, Wing et al. 1995, Wing and Currano 2013).

The scope of Brown's monograph included Paleocene strata from New Mexico, Colorado, Wyoming, Montana, North Dakota, South Dakota and a few sites in Canada (Text-fig. 2), distributed in several structural depressions including the Williston, Bull Mountain, Crazy Mountains, Clark's Fork, Bighorn, Powder River, Wind River, Hanna, Carbon, Green River, Denver, Raton, and San Juan basins (Fig. 1A, B in Peppe and Hickey 2014). Stratigraphically, the source sediments include the Fort Union, Raton, Denver, Bear, Lebo, Ferris Formations. In North Dakota, where the Fort Union is treated as a Group, the Ludlow, Tongue River and Sentinel Butte Formations, as well as parts of the Golden Valley Formation, were included. With greatly increased improvements to stratigraphic resolution in many of these basins through the Paleocene and especially proximal to the Creteaceous-Paleocene and Paleocene-Eocene boundaries (Hicks et al. 2003, Johnson et al. 2003, Belt et al. 2004, Peppe et al. 2009, Secord et al. 2006, Sprain et al. 2014), there is the excellent potential to place Brown's taxa according to more precise stratigraphic and chronologic ranges, but that is beyond the scope of the present article.

The systematic affinities of many of the species recognized by Brown (1962) have been revised over the past five decades, but the information is scattered among numerous publications. The ferns documented by Brown were reviewed in the context 


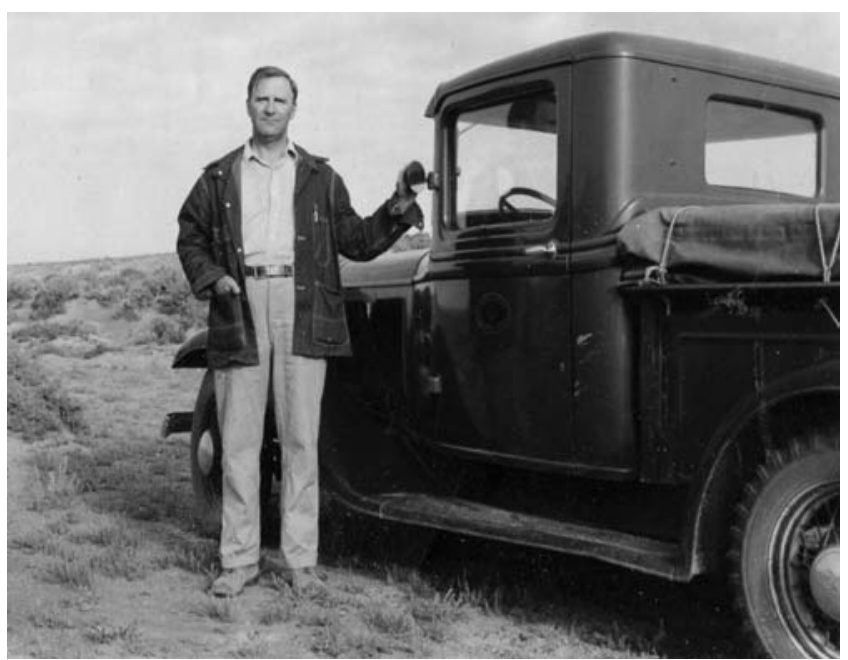

Text-fig. 1. Roland W. Brown in the field in SW Wyoming, June 30, 1941. Courtesy Nate Carroll, Carter County Museum, Ekalaka, Montana.

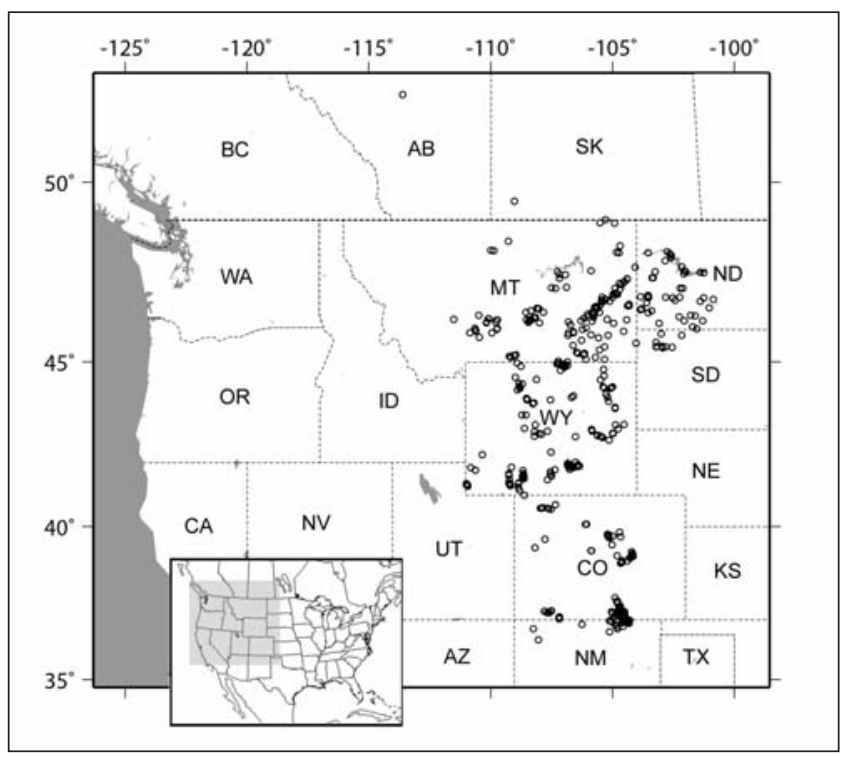

Text-fig. 2. Map showing the distribution of localities included in the treatment of Brown (1962), based on the coordinates presented in Appendix Table 1. Localities are distributed across New Mexico (NM), Colorado (CO), Wyoming (WY), Montana (MT), South Dakota (SD) and North Dakota (ND). Also plotted are cited Canadian localities: Joffre Bridge, in Alberta (AB), and Ravenscrag, in Saskatchewan (SK). Map generated with Map-It (2014) website.

of a broader Cenozoic treatment by Collinson (2001), but there has been no comprehensive review of the seed plants since Brown's original monograph. The Platanaceae, Saxifragales (Cerdiphyllaceae, Hamamelidaceae and others), Betulaceae, Juglandaceae, and Cornales figure prominently in the Paleocene of North America - more than was appreciated at the time of Brown's synthesis. For this article, all the taxa that Brown recognized are reviewed, indicating their botanical systematic positions as currently recognized. This account does not include some of the taxa recognized more recently that were unknown to Brown (1962) which can be found in the review of Pigg and DeVore (2010).
Because the sleuthing of correct botanical affinities for fossils that are incompletely preserved is a tedious process, the traditional binomial system of nomenclature has, in some cases, been effectively replaced by numerical morphotype designations that can be tallied quickly and used statistically in site-to-site comparisons for assessment of changes in floristic diversity and climate (Barclay et al. 2003; Ellis et al. 2003; Johnson 2002).

In another approach to dealing with uncertain taxonomic affinities, Hickey (1977) and others have found it useful to retain binomials from the older literature, even when the original generic assignment is considered to be correct, by placing the generic name in quotation marks, e.g. "Ficus" planicostata LESQUEREUX. In this example, the generic placement by Lesquereux is no longer considered correct, but the true botanical affinities remain uncertain, and a fossil-generic name has not been established to accommodate it. The use of such quotation marks in this treatment should be viewed as a warning that the modern generic name is not accepted and should not be used in ecological assessments of the flora nor for calibrating molecular phylogenies-unless new data are recovered from the fossils to justify the former assignments.

Most of the localities that Brown cited as the sources for his species (Text-fig. 2) were presented in a listing that provided geographic coordinates according to the township and range system and/or a brief text description. Here is provided an updated listing of the original localities along with their latitude/longitude coordinates.

\section{Material and Methods}

Specimens were studied at the US Natural History Museum, Smithsonian. This study is limited primarily to the localities cited by Brown (1962), which include sites of Newberry, Lesquereux, Ward and Knowlton as well as those collected by Brown, himself. Other relevant localities from more recent fieldwork of L. J. Hickey, S. Wing, K. Johnson, D. Peppe, and S. Manchester are mostly outside the scope of this article. Many of the sites in Wyoming, Montana and North Dakota were physically revisited. Other sites were located as closely as possible from original Township and Range coordinates using the Earthpoint (2014) website for conversion to latitude and longitude, and/or site descriptions, and were "digitally revisited" via GoogleEarth (2014) to obtain latitude/longitude coordinates adjusted to the WGS84 datum. Localities were plotted on the geographic map using the Map-It (2014) website. Geologic horizons represented include the Fort Union Formation/Group, and the Denver, Raton, Animas, Evanston, and Ferris Formations. We have excluded taxa that are exclusively from the Coalmont Formation of Colorado as it is likely of early Eocene, rather than Paleocene age (Hail and Leopold 1960). Appendix Table 1 lists the localities, their coordinates, and taxa recorded from them by Brown (1962). In addition, some of specimens are figured and/or cited herein are from localities represented in the collections at Florida Museum of Natural History, Gainesville (specimen numbers prefixed UF). These include Killpecker Creek, Wyoming (UF 18126: 41³5.635' N, $109^{\circ} 15.197^{\prime} \mathrm{W}$ ), Black Buttes Mine pit 3, Wyoming (UF 15886: $\left.41^{\circ} 29.41^{\prime}, \mathrm{N} 108^{\circ} 41.22^{\prime} \mathrm{W}\right)$, the Almont, North 
Dakota (UF 15722: 4655.32' N, 101 $30.38^{\prime} \mathrm{W}$ ), and Yellowstone Bridge, Miles City, Montana (UF19021: 46 25.69’ N, 105 50.96W).

The repeated association of particular fruit and leaf types among different localities, as well as at other sites discovered subsequent to Brown's work, was used along with other evidence to link multiple organs of the same species when possible as in the cases of Macginitiea, Nordenskioeldia, Polyptera, Aesculus, Davidia, Beringiaphyllum, and Browniea.

The names used here are believed to be those with priority according to the International Code of Botanical Nomenclature (McNeill et al. 2012, Turland 2013). The Latin endings from previous publications have been corrected, when appropriate. Such corrections can be done without altering the author attribution (McNeill et al. 2012, Turland 2013). For example, Nordenskioeldia was spelled Nordenskioldia by Brown (1962) and by Crane et al. (1990, 1991), but as the name honors Nordenskiöld, the "o" with umlaut is to be replaced by "oe" rather than simply "o". The most common correction was the use of the suffix, "il" rather than " $i$ " in the case of species recognizing a man's name when preceded by a consonant (except " $r$ ", which is treated as a vowel). Hence, for example, Betula stevensoni LESQUEREUX, as spelled by Brown (1962), is corrected to Betula stevensonii LESQUEREUX. For brevity, I have not repeated the synonymies provided already by Brown, unless our opinions differ.

\section{Taxonomic Composition of the Flora}

Table 1 lists currently recognized taxa according to their position in phylogeny as currently understood. In addition, Table 2 repeats the taxonomic listing from Brown (1962), in the same sequence as he presented it, with indication of revised taxonomic placements and/or indication of whether the taxonomic placement is accepted or in need of revision. The following discussion of taxonomic composition of the flora is presented by major taxonomic groups, i.e., ferns, gymnosperms, and angiosperms divided into the morphologically distinctive groups, monocots and dicots. The dicots are treated in more or less phylogenetic sequence (sensu APG III 2009): e.g., Platanaceae, Saxifragales, Fagales (Betulaceae, Juglandaceae), Rosales (Ulmaceae), Cornales (Cornaceae, Nyssaceae, Davidiaceae), followed by those of uncertain affinity.

\section{Bryophytes}

Free-sporing plants are subdominant to seed plants in most Paleocene leaf localities and bryophytes are rare. Liverworts are represented by Marchantia lignitica (WARD) R. W. Brown, M. pealei Knowlton and Preissites wardii KNOWLTON (Brown 1962), and mosses by "Hypnum" coloradense R. W. BRown and "Mnium" montanense R. W. BROWN.

\section{Lycophytes}

Lycopods include three species of Selaginella $(S$. berthoudii Lesquereux, S. collieri Knowlton, and $S$. monstrosa (HOLLICK) R. W. BROWN) and Isoetites horridus
(DAWSON) R. W. BROWN. The corms, leaves and sporangia of Isoetites horridus, indicate relationship to extant Isoetes, but the species is distinguished from the extant genus by differences in vegetative characters, for example, shape of the leaf apices, which are spatulate in the fossil (Brown 1939a, McIver and Basinger 1993). I. horridus was shown by Hickey (1977) to produce megaspores similar to the dispersed spore taxon, Minerosporites dissimilis; McIver and Basinger (1993) found both megaspores of Minerosporites, and microspores of Lavigaetisporities gracilis WILSON et WEBSTER in situ.

\section{Sphenophytes}

Equisetum is sometimes present, represented by stems and/or rhizomes and sometimes by rhizome nodules but detailed comparative studies with other fossil and extant species have not been done. Brown (1962) cited various epithets that had been applied earlier for specimens from the Rocky Mountains and Great Plains region, but did not settle on an appropriate bionomial, noting that "When, however, these species are examined in the light of the material now on hand, they do not seem to be readily distinguishable. Size of stem, number of teeth in the sheaths, shape of the tubers - all vary so greatly, with gradations from one to another, and with no apparent constancy in any set of features, that I shall not attempt to define the species" (Brown 1962, p. 46). Among Paleocene examples from this region, Equisetum globulosum LESQUEREUX (1883, p. 222, pl. 48, fig. 3 ) appears to have nomenclatural priority. A strobilus was also illustrated by Brown (1962, pl. 67, fig. 43).

\section{Filicalean Ferns}

Brown (1962) recognized 13 genera of ferns. The phylogenetic positions of some of these remain questionable because of poor preservation (as Brown acknowledged for "Hymenophyllum" confusum), lack of fertile material, and/or problems of convergent morphology in multiple unrelated extant fern genera. Nevertheless, some of the identifications can be considered to be secure including Lygodium, Woodwardia, Onoclea, and Osmunda.

\section{Schizaeaceae}

In the Schizaeaceae, Lygodium coloradensis KNOWLTON can be identified with confidence based the diagnostic fertile foliage and the palmately lobed pinnules (Brown 1962, pl.8 figs 9,10 ) (confirmed by a small piece of fertile foliage resembling that of L. kaulfussii). Lygodium is very rare in the Paleocene of this region, but becomes abundant in the Eocene. The generic assignment of Anemia elongata (NEWBERRY) KNOWLTON is in question because only sterile foliage is known, and because similar fossil foliage, including A. eocenica BERRY, was reassigned to the related extinct genus Ruffordia SAPORTA by Barthel (1976) on the basis of similarity to more completely documented Eocene European fossils that differ from extant Anemia in various details, including the presence of monolete, rather than trilete spores within the sporangia. Ruffordia differs from Anemia in 
having less reduced fertile laminae, more spores per sporangium (256 vs 128) and in epidermal anatomy (Barthel 1976), but these features are not known for "Anemia" elongata. Collinson (2001) cautiously listed this species under "Anemia-like sterile foliage."

\section{Osmundaceae}

Brown recognized two species of osmundaceous foliage, Osmunda greenlandica (HEER) R. W. BROWN [original spelling of epithet groenlandica (HEER 1869)] and $O$. macrophylla Penhallow, noting that both were known only from sterile foliage without fertile fronds. Additional evidence favoring the identification of this genus came from Tidwell and Parker (1987) who described permineralized osmundaceous stem remains associated with pinnules that they identified as $O$. greenlandica from the Fort Union Formation at Black Buttes Coal Mine on the west side of the Rock Springs uplift in Wyoming. O. macrophylla foliage was also observed in the Golden Valley Formation (Hickey 1977, p. 59).

\section{Onocleaceae}

The generic placement of Onoclea hesperia R. W. BROWN was accepted by Rothwell and Stockey 1991, but they argued, based on a suite of material from the Paleocene Paskapoo Formation of Alberta, Canada, that these fossils should be placed in the extant species, O. sensibilis L.in agreement with the original assignment of Newberry (1898). McIver and Basinger (1993) applied Brown's binomial to sterile material from Paleocene of Ravenscrag, Saskatchewan.

\section{? Dennstaedtiaceae}

"Dennstaedtia" americana KNOWLTON is known from both fertile and sterile fronds (Knowlton 1910; Brown 1962; McIver and Basinger 1993). McIver and Basinger (1993) illustrated and described additional material of this species from the Paleocene of Saskatchewan. Kvaček and Manum (1993) noted that it can be difficult to distinguish sterile and even fertile fronds of Dennstaedtia and Saccoloma (Dennstaedtiaceae) from those of certain genera of the unrelated tree fern family, Dicksoniaceae. They transferred a Paleogene species from Spitsbergen, previously considered to be Dennstaedtia, to the fossil genus Coniopteris Brongniart: Coniopteris blomstrandii (HeER) KVAČEK et MAnum. They also recommended that $D$. americana be reconsidered in this light, but did not make a formal transfer. A more detailed investigation is requried, aimed at revealing the morphology of sporangia and spores.

The fern that Brown (1962) placed in Saccoloma gardneri (LESQUEREUX) KNOWLTON was subsequently treated as an extinct genus Dennastra under the name $D$. sorimarginata McIver et BAsinger (1993). Dennastra leaves show a reticulate venation at the outer edges of the pinnules (Knowlton 1930, McIver and Basinger 1993). The specimen illustrated by Knowlton (1930) shows an elongate, entire-margined pinnule at least $6 \mathrm{~cm}$ long and $1 \mathrm{~cm}$ wide with thick midvein, thin dichotomizing secondary veins, and a thick marginal band of sori. Similar specimens occur in the Ravenscrag Formation of Saskatchewan (McIver and Basinger 1993). The proper placement of Lesquereux's species remains uncertain; McIver and Basinger (1993, p. 21) reported that, "Evidence from Ravenscrag Butte fossils indicates that this fern is not assignable to Saccoloma, and that fertile pinnules of this type are unlikely to be conspecific with the type specimen of the basionym Pteris gardneri." Collinson (2001, p. 216), concluded "The characteristics of Dennastra are closely comparable to those of modern Saccoloma, especially S. elegans KAULF., though slight differences in venation occur in addition to the spore differences. The inclusion of Dennastra in Dennstaedtiaceae seems to be well-supported by the published data."

\section{Blechnaceae}

The generic identification of Woodwardia arctica (HEER) R. W. BROWN from Wyoming and North Dakota is secure because of the prominent, continuous bands of sori that follow both sides of the rachis and both sides of the midvein of each pinnule. The venation and soral development are particularly similar to the extant species, Woodwardia virginica, sometimes placed in its own genus, Anchistea. $W$. arctica was also reported from the Eocene of Japan (Endo 1968), and from the Zeya-Bureya depression of far eastern Russia (Kvaček and Manum 1993; Fedotov 1970). Hickey (1977) and McIver and Basinger (1993) applied the name Woodwardia gravida HICKEY for similar specimens from which spores were obtained. Woodwardia maxonii Knowlton, from the Paleocene of Wyoming and North Dakota (McIver and Basinger 1993, Hickey 1977) differs from $W$. arctica by having separate elliptical sori, rather than continuous linear sori.

\section{Incertae sedis ferns}

Allantodiopsis erosa (LESQUEREUX) KNOWLTON et MAXON is a fern of uncertain affinity. The pinnules have feather-like venation. Secondary veins are approximately at right angles to the midveins and have dichotomous forking near the midvein and sometimes again near the margin. Although Knowlton and Maxon (in KNOWLTON 1919) and Brown (1962) included both entire-margined and nonentire-margined pinnae in A. erosa, McIver and Basinger (1993) advised that this species should be restricted to the nonentire-margined form matching the original specimens of Lesquereux, because the entire-margined lamina from Knowlton and Maxon's locality overlaps with a co-occurring species that Knowlton called Saccoloma gardneri (LESQUEREUX) KNOWLTON (cf. Dennastra sorimarginata MCIVER et BASINGER 1993).

"Blechnum" anceps (Lesquereux) R. W. Brown. This species is known only from sterile foliage, and thus the assignment should be regarded as tentative. Each pinnule has a midvein and closely spaced fine secondary veins. The distal portions of the secondary veins are almost at right angles to the midvein, and "the vein terminations in the margin are conspicuously enlarged or club shaped" Brown (1962, p. 41). 
Brown recognized three species of Dryopteris, two based in part on fertile fronds, D. lakesii (LESQUEREux) KNOWLTON, and $D$. meeteetseana $\mathrm{R}$. W. BROWN showing sori but lacking preservation of spores, and the third based on sterile foliage called D. serrata R. W. BROWN, for which he stated "no comparison with a living species is suggested, and the reference to Dryopteris is entirely nominal" (Brown 1962, p. 42). Collinson (2001) considered all paleobotanical reports of Dryopteris, including these, to be in need of revision.

"Lastrea" goldiana (LeSQuereuX) LESQuereuX. Brown (1962, p. 42) stated that "fertile pinnae are scarce ..., but when present have small round sori on the secondary veins midway between the midrib and margin." This is similar to a fern from the Paleocene of Alberta given the name Speirseopteris orbiculata and assigned to Thelypteridaceae by Stockey et al. (2006). The venation and position of sori correspond, with a circular sorus terminating each secondary vein inside the margin, but the pinnules are shorter with fewer secondary veins than in the specimens illustrated by Brown of L. goldiana.

"Gleichenia" hesperia R. W. BROWN was described based on sterile pinnules, but Brown (1962, p. 44) admitted, "The specimens are only nominally assigned to Gleichenia."

\section{Gymnosperms}

Gymnosperms present in Paleocene assemblages of the Rocky Mountains and Great Plains include Ginkgo, conifers, and cycads.

\section{Cycads}

Brown recognized the cycads Zamia coloradensis (Knowlton) R. W. Brown and Z. wyomingensis R. W. BROWN. However, in the absence of epidermal characters and cones, it is difficult to confirm that they represent extant Zamia. Other Paleocene cycads with superficial similarities to Zamia have been shown on epidermal characters to represent an extinct genus, Dioonopsis HorIUCHI et KIMURA (Erdei et al. 2012). According to B. Erdei (pers. comm. 2013), the type specimens of these species both lack well preserved cuticle so it cannot be confirmed whether they represent Zamia, or another genus. In addition to the kinds recognized by Brown (1962), the extinct cycad genus, Eostangeria BARTHEL, with feather-like venation and well preserved cuticle, has been recovered from the Paleocene of Wyoming, including Little Bitter Creek Canyon and Sand Draw localities in Wyoming (Kvaček and Manchester 1999).

\section{Ginkgoaceae}

Brown (1962) referred to the leaves of Ginkgo, as Ginkgo adiantoides (UNGER) HeER. Zhou et al. (2012) described the same species from well preserved leaves and reproductive structures from silicified specimens, and named them Gingko cranei ZHOU, QUAN et LIU, because the type material of $G$. adiantoides from the Pliocene of Italy is known only from leaf impression material lacking many of the characters known for $G$. cranei. I was recently reminded, however that Ginkgo wyomingensis MANUM (1966) was also described from Palaeocene of USA (reviewed by Golovneva 2010) and the structure of its cuticle is the same that of G. cranei, so the nomenclature needs to be revisited.

\section{Conifers}

Conifers include Amentotaxaceae and Cupressaceae. Leaves that Brown called Amentotaxus campbellii (Gardner) Florin were transferred to Amentotaxus gladifolia (LUDWIG) FERGuson, JÄHNICHEN et ALVIN by Jähnichen (1990). Although Pinaceae are well represented in the palynoflora, e.g., Abietineaepollenites foveoreticulatus, Pinus, Picea, Abietineaepollenites latisulcatus, Pinuspollenites elongatus, and Cathaya sp. (Zetter et al. 2011), but they are not known from megafossils.

\section{Araucaria longifolia (LESQUEREUX) R. W. BROWN}

Brown's determination of compressed cones and foliage as Araucaria longifolia (LESQUEREUX) R. W. BROWN has not been formally challenged. However, the identification to this family is in need of careful scrutiny, as it would be among the youngest records of this family for the Northern Hemisphere.

In the taxoidioid Cupressaceae, Metasequoia and Glyptostrobus are well represented based on foliage and cones. Glyptostrobus is represented by foliar branches with terminal cones, and by dispersed seeds.

\section{Glyptostrobus europaeus (BRONGNIART) UNGER}

Brown (1962) used the name Glyptostrobus nordenskioldii (HEER) R. W. BROWN, based on similarity to original material from the Paleogene of Spitsbergen (recently reanalyzed by Budantesev and Golovneva 2009). Hickey (1977) argued that there were insufficient foliage and cone characters to distinguish the North American fossil Glyptostrobus species from that of Europe, and that the name Glyptostrobus europaeus (BRONGNIART) HEER should be applied both to North American and European material. LePage (2007) observed that this combination was actually published earlier by Unger (1850), and so should be cited as Glyptostrobus europaeus (BRONGNIART) UnGER. LePage (2007) reported that more than 30 binomials have appeared in the literature on fossil occurrences of Glyptostrobus around the Northern Hemisphere ranging from Cretaceous to Pliocene, most of which appear indistinguishable based on their diagnoses and stressed that there is need for more detailed comparative work among them.

Taxodium olrikii (HEER) R. W. BROwN was reported from the Rocky Mountain and Great Plains region based on leaves, but no confirming seeds or cone fragments have been recognized so the identification of Taxodium remains unconfirmed. This species was originally recognized from the Paleocene of Greenland, and then from Spitsbergen, but convincing reproductive material remains to be documented (Budantsev and Golovneva 2009).

\section{Metasequoia occidentalis (NEWBERRY) CHANEY}

Metasequoia occidentalis (NEWBERRY) CHANEY is correctly identified to genus based on the oppositely arranged 
needle leaves, and cones with decussate arrangement, based on specimens collected from the Paleocene of Wyoming, Montana and North Dakota. From Paleocene strata in Alberta, Stockey et al. (2001) recognized another species, M. foxii Stockey, Rothwell et FAlder, distinguished by cones with helical arrangement of five rows of cone scales, rather than four decussate rows. This seems to represent a different species from most of the material illustrated by Brown (1962). Crane et al. (1990) placed permineralized taxodioid megafossils from the Paleocene of Almont, North Dakota, in "cf. Parataxodium ARNOLD et LowTHER"; however, subsequent collections and study indicate that these remains mostly represent the foliage, pollen and seed cones, and dispersed seeds of Metasequoia occidentalis. A characteristic seed of Glyptostrobus, recovered more recently from Almont, indicates that the Glyptostrobus-like foliage that Crane et al. (1990) considered to be variation within cf. Parataxodium, was likely produced instead by Glyptostrobus europaeus.

\section{Ditaxocladus catenulatus (W.A. BELL) S.X. GUO, Z. KVAČEK, MANCHESTER et Z.K. ZHOU.}

The cupressaceous foliage that Brown (1962) referred to as Fokienia catenulata (BELL) R. W. BROWN (MCIVER and BASINGER 1990) was subsequently found with attached cones and placed in the extinct genus Ditaxocladus Guo et SuN. The species was transferred to Ditaxocladus catenulatus by Guo et al. (2012). Fokeniopsis McIver et BASINGER (1993) is a junior synonym of Ditaxocladus Guo et Sun (in Guo et al. 1984).

\section{Mesocyparis borealis MCIVER et BASINGER}

Foliar branches referred to Thuja interrupta NEWBERRY by Brown (1962) have been revised multiple times. Hickey (1977) called this species Thuites interruptus (NEWBERRY) BeLl, using Sternberg's genus Thuites. McIver and Basinger (1987) placed them in Cupressinocladus interruptus (NewberRY) SchweItzer, adopting Schweitzer's (1974) recommendation that the form-genus Cupressinocladus Seward be applied to vegetative material when reproductive organs are not present. The same kind of foliage, with attached cones, was placed in a new genus and species, Mesocyparis borealis, from the Paleocene of Ravenscrag, Saskatchewan (McIver and Basinger 1987). A short time later, Golovneva (1988) published a similar new genus and species as Microconium beringianum. In their subsequent survey of Cretaceous and Tertiary Thuja-like remains, McIver and Basinger (1989, p. 1911) considered oppositely branching foliage as Chamaecyparis interruptus (NEWBERRY) SCHWEITZER, but it seems likely that these represent fragments of Mesocyparis. Under the philosophy that vegetative and reproductive branches be treated separately, the appropriate names for this taxon are Cupressinocladus interruptus (NEWBERry) SchWEITZER, and (if cones are attached) Mesocyparis borealis McIver et BASINGER. The reason for this is that the same kind of foliage could be produced by more than one genus of Cupressaceae, and is thus placed in a catchall fossil-genus. The presence of cones permits a better resolved identification.

\section{Angiosperms}

\section{Nymphaeaceae}

Brown included Cabomba inermis (NEwBERRY) Hollick, Nymphaea leei (KNowlton) R. W. Brown, Nymphaea pulchella (KNOWLTON) R. W. BROWN, and Paleonuphar hesperium R. W. BROWN among the water lilies cited from the Paleocene floras. The leaves assigned to Nyphaea appear to be correctly identified. The remains assigned to Cabomba are dichotomously branched unwebbed structures that correspond closely to roots known for the non-nymphaealean extinct genus, Quereuxia. The extinct genus Paranymphaea was subsequently transferred to Polygonaceae by McIver and Basinger (1993; see below).

\section{Magnoliaceae}

"Bauhinia" wyomingana R. W. BRown. Although bilobed with a laminar outline similar to that of Bauhinia, the illustrated specimen differs in venation (pinnate, rather than actinodromous) and lacks the petiole morphology expected for that genus, and other legumes. It appears, instead to represent a leaf of Magnoliaceae, cf. Liriodendron. It is closely similar to the leaf known as Liriodendron iijimae TANAI from the upper Cretaceous (Senonian) of Japan (Tanai 1979). Kirk Johnson (1996, in his discussion of another taxon, Liriodendrites bradacii K. JOHNSON) mentioned that more specimens of this kind occur in the Great Divide Basin. " $B$." wyomingiana is represented only by the single specimen illustrated by Brown, and the upper fragment is missing from the type collection, so that only the basal part of the illustrated specimen is available for continued study. The original site for this species is no longer accessible due to completed mining activity.

Although Brown (1962) treated several species as Magnolia, the leaf architectural characters of extant Magnolia are not unique to that genus or family. Entire-margined pinnately veined leaves occur in many families so the assignment of Magnolia is based on general similarity rather than on diagnostic characters.

\section{Lauraceae}

Leaves of Lauraceae are entire-margined with pinnate secondaries that in some genera can be arranged with a basal or suprabasal pair of acrodromous secondaries. Similar venation can occur elsewhere among angiosperms, for example in Araliaceae, Hamamelidaceae, and Menispermaceae. When cuticle is preserved documenting paracytic stomata and oil cells, the affinities with Lauraceae can be substantiated, but cuticle was not examined for the species investigated by Brown. The familial and generic assignments for these taxa need verification: Cinnamomum sezannense WATElet, Laurophyllum caudatum (KNOWLton) R. W. BRown; Laurophyllum perseanum R. W. BROWN; Laurus socialis LESQUereuX; Lindera obtusata (WARD) R. W. Brown; Persea brossiana Lesquereux; and Sassafras thermale (LESQUEREUX) R. W. BROWN.

"Melastomites" montanensis R. W. Brown. Brown (1962) noted that the leaves he attributed to Melastomites 
Unger are similar to those of Sassafras and Cinnamomum (Lauraceae) as well as with Tococa of Melastomataceae. The leaves do not, however, show the strongly impressed percurrent tertiaries typical of Tococa and other Melastomataceae. Brown indicated that "surfaces of the better preserved leaves display minute dots, about 300 per sq $\mathrm{cm}$, that were probably glandular". These might represent the hardened contents of oil cells common in Lauraceae.

“Artocarpus" lessigiana (LESQUEREUX) KNOWLTON. Brown (1962) provided a helpful synonymy of the previously published occurrences of this species. The leaves are large, and deeply pinnately lobed with deep, rounded intralobal sinuses, superficially resembling extant Artocarpus. Kirk Johnson (pers. comm. 2014) noted: "We dug hundreds of "Artocarpus" leaqves in the Denver Basin, most from the first 2-3 million years of the Paleocene. They could be quite large, up to 20 inches long so they continue the resemblance to Artocarpus, but lack all of the distinctive venation of Moraceae. At Castle Rock, we also collected leaves that were strikingly similar to true Sassafras in their morphology and venation. Close comparison of the big lobed "Arctocarpus" with the Sassafras suggested affinity to the Lauraceae." Garland Upchurch studied the cuticles of similar specimens from the Denver and Raton Basin and also indicated lauralean affinities (Kaufmann et al. 1990; Upchurch and Wolfe 1987).

\section{Chloranthaceae}

\section{“Myrtophyllum” torreyi (LESQUEREUX) DORF}

This species is a rare element of the Paleocene flora. In their discussion of the mid-Cretaceous chloranthaceous species, Crassidenticulum decurrens (LESQUEREUX) UPCHURCH et DILCHER, Upchurch and Dilcher (1990) noted that "C. decurrens" closely resembles "Myrtophyllum" torreyi (LESQuereuX) DORF, such as specimens photographically illustrated by Brown (1962, pl. 50, figs 1-4, 7-9), in nearly all preserved features but differs in having secondary veins that arch apically and directly enter the teeth, rather than connect with an intramarginal vein. Thus, while the two species may be congeneric, they are distinct." Accordingly, the leaves of $M$. torreyi may also represent Chloranthaceae. The genus Myrtophyllum HeER (1869) (non TuRCZ.), based on a type from the Cretaceous of Bohemia, is inappropriate to accommodate this species.

\section{Monocots}

Monocots in the Paleocene of the Rocky Mountain and Great Plains region include palms, gingers, and aquatic araceous representatives. The palms include leaves named Chamaedorea danae (LesquereuX) Berry, Paloreodoxites plicatus (LESQUereuX) KNOWLTON [Fossil genus of Knowlton, accepted by Read and Hickey 1972], Sabal grayana LesquereuX, S. imperialis DAWSON, S. powellii NEWBERry [= Sabalites powellii (NEWBERRY) E.W. BERRY sensu Read and Hickey], Thrinax dorfii R. W. BRown [= Palmacites dorfii (R.W. BROWN) READ et HICKEY].

\section{Araceae}

\section{Limnobiophyllum scutatum (DAWSON) KRASSILOV}

Brown (1962) agreed with the concept of Hantke (1954) that the fossil species, Hydromystria expansa (HEER) HANTKE included two morphologically distinct kinds of foliage, firstly the thin, orbicular peltate leaves that Dawson had called Spirodela scutata and secondly a thick kidney-shaped structure interpreted as float leaves which were later called Porosia verrucosa Hickey (Hickey 1977, emended by Manchester and Kodrul 2014). The orbicular, thin, leaves were subsequently reassigned to a new extinct genus, Limnobiophyllum by Krassilov (1973 1976) who recognized the same species in the Paleocene of E Asia). Limnobiophyllum scutatum (DAWSON) KRASSILOV was proven to represent Araceae-Lemnaceae based on specimens with attached flowers containing stamens with pollen (Stockey et al. 1997), whereas the Porosia structures, mentioned again below, have turned out to represent unrelated singleseeded dicotyledonous fruits of possible rutaceous affinity as revealed by permineralized specimens (Manchester and Kodrul 2014).

\section{Zingiberales}

The leaf attributed to Canna? magnifolia KNOwLton (Brown 1962, pl. 15, fig. 2) was transferred to Zingiberopsis isonervosa HickeY by Hickey and Petersen (1978), and considered to represent Zingiberaceae. Zingiberites dubius LESQUEREUX is based on a fragmentary specimen from the Denver Formation was that reexamined by Brown, but no additional Paleocene specimens have been recovered for more detailed evaluation.

Ensete goldianum (LESQUEREUX) comb. nov.

Text-figs 3.1, 3.2

1878 Viburnum goldianum LeSQUEREUX, Rept. U. S. Geol. Surv. Terr., 7, p. 227, pl. 60, figs 2, 2a-c (holotype and basionym).

This species, based on a grouping of seed impressions preserving both internal and external details, also represents Zingiberales. These smooth, subelliptical seeds with a truncate apex show an opercular collar similar to the configuration in extant and fossil Ensete. Although the chalazal chamber is not preserved in the casts, there is an axial perforation of the seedcoat at the base similar to that seen in extant Ensete. These resemble those described from better-preserved permineralized specimens from the Eocene of Oregon (Manchester and Kress 1993).

\section{Other monocots}

Haemanthophyllum sp. 3. sensu Golovneva (1997). Brown (1962) assigned leaves to Alismaphyllites grandifolius (Penhallow) R. W. Brown, using the generic Alismaphyllites KNOWLTON (1917) based on specimens from the Raton Formation near Trinidad, Colorado (Knowlton 1917, p. 286, pI. 55, fig. 1). The original specimen of Alisma- 


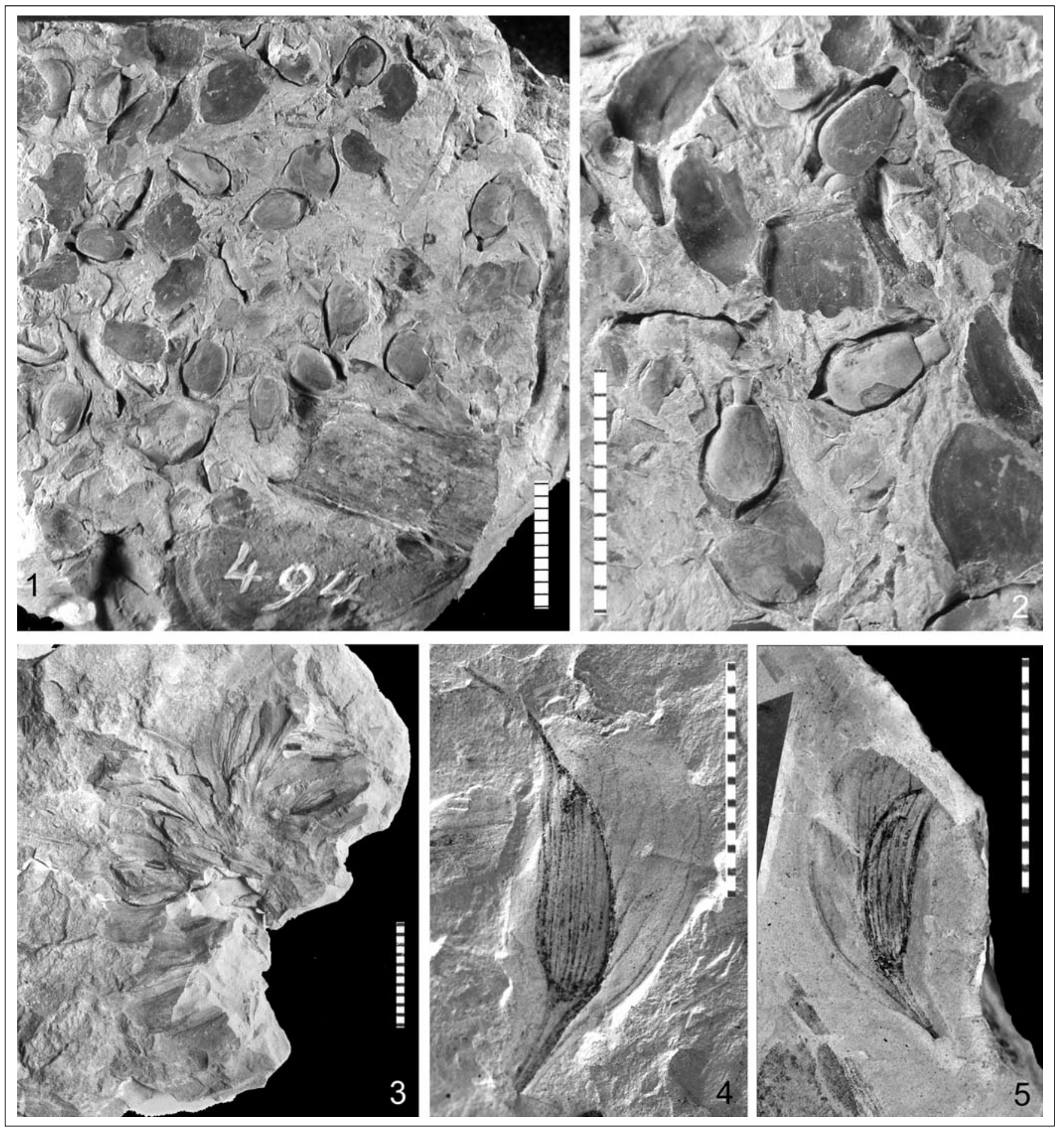

Text-fig. 3. 1, 2. Ensete goldianum (LESQUEREux) comb. nov, Holotype, USNM 494, Golden Colorado. 1. Numerous seeds on a slab. 2. Detail of seed molds and casts. 3-5 "Sagittaria" megasperma R. W. Brown. 3. Infructescence head. USNM 167488, lectotype selected by Watt 1971. 4. Isolated fruit showing veins of wing, and longitudinally striate central body and single style, USNM 313282, 5. Additional isolated fruit, USNM 313283. Images 4,5 light-dark inverted. Scale $=1 \mathrm{~cm}$.

phyllites crassifolium KNOWLTON (1917), the type species of Alismaphyllites, was a stem with three attached broad monotyledonous leaves, but the venation is not sufficiently preserved for detailed comparison with the leaves later assigned to Haemanthophyllum. Golovneva (1997) designated the illustrated specimens of Brown (1962) as "Haemanthophyllum sp. 3." Golovneva (1997) studied various extant families with foliage similar to Haemanthophyllum, e.g., Alismataceae, Potamogetonaceae and
Aponogetonaceae. She concluded that Aponogetonaceae was more probable as to its affinities, but, also stated "The most similar to Haemanthophyllum, the alismatacean genus Caldesia, has smaller leaves." So far, the reproductive organs of this plant remain unknown.

"Sagittaria" megasperma R. W. BROWN (Text-figs 3.3-3.5) is based on globose infructescences of winged fruits. The distinctive leaves of Sagittaria have not been observed. The winged fruits show a single style and asymmetrical to 
less commonly symmetrical wing development. The seed body is covered by closely spaced longitudinal veins. The wings have longitudinal veins unlike modern species of Sagittaria, so the affinities of this distinctive plant are uncertain.

The globose infructescences that Brown (1962) referred to Sparganium antiquum (NEWBERRY) BERRY are not monocots but instead represent Platanaceae. They were found at the same locality (USGS 2416) as Macginitiea nobilis.

\section{Ceratophyllaceae}

\section{Ceratophyllum furcatispinum HERENDEEN, LES et DILCHER}

Among the unidentified specimens curated in the USGS collections by Brown, but not included in his publication, were spiny fruits subsequently identified as those of Ceratophyllum (Herendeen et al 1990). Several specimens of Ceratophyllum furcatispinum HERENDEEN, LES et DILCHER were cited, all from a single locality in Montana.

\section{Menispermaceae}

Fruits found in Paleocene strata of North Dakota and Wyoming subsequent to the publication of Brown's monograph confirm the presence of Menispermaceae. Horseshoe-shaped endocarps have been described from Almont, North Dakota, as cf. Canticocculus CHANDLER (Crane et al. 1990, fig. 5A-C) and as Palaeoluna sp. from Linch, Wyoming (Fig. 17 in Herrera et al. 2011). Corresponding leaves remain elusive. Those that Hickey (1977) regarded as Menispermaceae, i.e., "Cocculus" flabella (NEWBerRy) J. Wolfe and Menispermites parvareolatus HiCKEY, were subsequently transferred to Zizyphoides SEWARD et CONWAY, and probably belonging to same plant as Nordenskioeldia fruits (Crane et al. 1991).

\section{Sabiaceae}

The presence of Sabiaceae is confirmed on the basis of distinctive well preserved endocarps of Meliosma rostellata (LeSQUEREUX) CRANE, MANCHESTER et DilCHER at Almont, North Dakota, and Golden, Colorado. The corresponding leaves, however, remain uncertain. Meliosma today can have either serrate or entire-margined leaves, and pinnate venation with well organized percurrent tertiary venation and orthogonal higher order venation, and such leaves are known from the Eocene of Oregon (Chaney and Sanborn 1933, Manchester 1981). Hickey (1977) applied the name Meliosma longifolia (HEER) HICKEY to some of the same leaves that had earlier been called Quercus sullyi by Brown (1962); however, the specimens illustrated by Hickey, and most of those treated as $Q$. sullyi by Brown, instead appear to represent the extinct genus Dyrana Golovneva (1994, Budantsev and Golovneva 2009). The rounded sinuses and glandular (rather than spinose) teeth may indicate that they represent Platanaceae, rather than Sabiaceae.

\section{Nelumbonaceae}

Among the several aquatic angiosperms recognized by Brown, Nelumbium montanum R. W. BROwN, Nelumbium tenuifolium Lesquereux, and Paleonelumbo macroloba KNOWLTON are peltate leaves that appear to be related to extant Nelumbo. An excellent specimen of Paleonelumbo macroloba was figured by Barclay et al. (2003, figs 9a-c).

Nelumbago montanum (R. W. BROWN) MCIVER et BASINGER

Nelumbium montanum R. W. BROwN was transferred to a new genus Nelumbago by McIver and Basinger (1993) who indicated that Nelumbium was inappropriate because it is simply an orthographic variation of Nelumbo. They illustrated an additional nice leaf from the Ravenscrag Formation of Saskatchewan, Canada. McIver and Basinger (1993) did not, however, indicate any nomenclatural change for Nelumbium tenuifolium LESQUEREUX, and they specifically excluded that species from the synonymy of $N$. montanum. Brown (1962, p 69) indicated that "there appears to be a close relationship between [N. tenuifolium] and Paleonelumbo macroloba KNOWLTON, and the former may be merely a variant of the latter."

\section{Platanaceae}

Brown recognized only two species of Platanaceae, which he referred to as Platanus nobilis NEWBERRY and $P$. raynoldsii NEWBERRY. Subsequent studies indicate that the sycamore/plane tree family was diverse in the Paleocene of the Rocky Mountains and Great Plains region with at least six species readily distinguishable on the basis of foliar characters.

\section{Macginitiea J. WOLFE et WEHR}

Leaves of the extinct genus Macginitiea are distinguished from those of extant Platanus by a narrower angle between adjacent primary veins, and a chevron pattern formed by interconnected secondary veins between adjacent primaries in the lower part of the lamina (Manchester 1986, Wolfe and Wehr 1987), and are consistently associated with infructescences that differ from those of modern Platanaceae by the lack of dispersal hairs on the fruits (Macginicarpa) and stamens dispersed in floral units of five, adhering by their elongate connectives (Macginistemon; Manchester 1978). The stamen units illustrated as "calyx of a flower" by Brown (1962, pl. 68, fig. 27-29) correspond to Macginistemon mikanoides (MACGinitie) MANChester (1978), and probably derive from the same trees as Macginitiea.

Brown (1962) considered both 3- and 5-lobed leaves to represent a single species, Platanus nobilis NewBerry. However, it seems probable that the 5- and 3-lobed populations represent distinct species, because many localities are greatly dominated by, or exclusively represented by, one kind or the other. Trilobate leaves are lacking from some of the other species of Macginitiea, e.g., M. angustiloba and $M$. whitneyi from the Eocene of California and Oregon (Manchester 1986). 


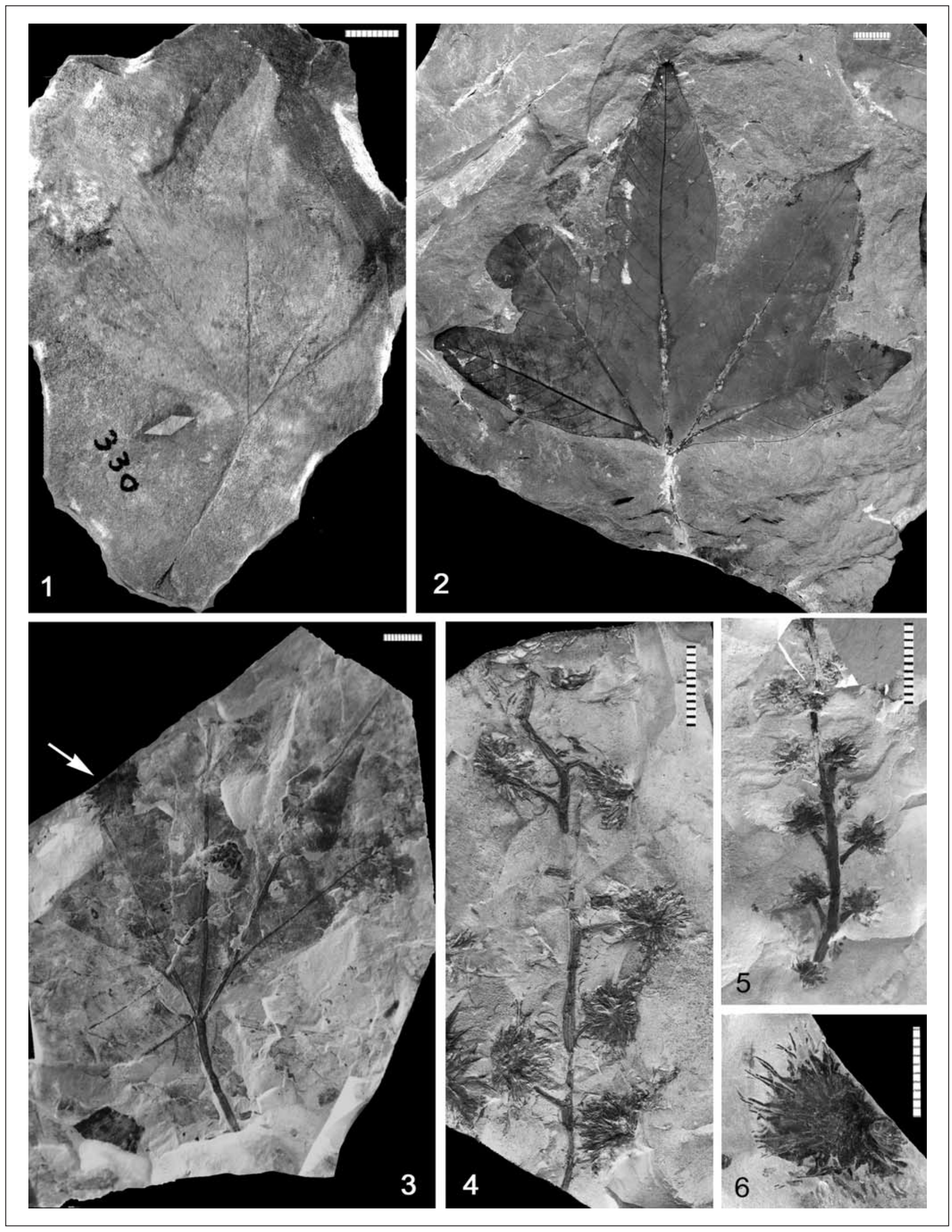

Text-fig. 4. Platanaceae 1-3. Macginitiea gracilis (LeSQuereux) J. Wolfe et WeHR leaves and associated reproductive structures 1. Holotype of Aralia gracilis LESQUEREUX from Bridger Pass, Wyoming, USNM 330. 2. Specimen showing the typical configuration of five lobes, Killpecker Creek flora, Wyoming. UF 18126-13242. 3. Silicified M. gracilis leaf from Almont, North Dakota; arrow indicates adjacent Macginicarpa infructescence, UF 15722-29202a. 4. Macginicarpa infructescence from Almont, UF15722-35493. 5. Platananthus sp., Almont, UF 15722-62019. 6. Macginicarpa glabra MANCHESTER infructescence, enlarged from fig. 3, UF 15722-29202b. Specimens in figs 3-6 collected and donated by John Curtis. Scales = $1 \mathrm{~cm}$. Images 3-6 light-dark inverted. 
Macginitiea gracilis (LESQUEREUX) J. WOLFE et WEHR

$$
\text { Text-figs 4.1-4.3 }
$$

Macginitiea gracilis is the type species of Macginitiea as designated by Wolfe and Wehr (1987), based on a deeply 5-lobed specimen collected by Hayden from Bridgers Pass, Wyoming from a fine sandstone of probable Maastrichtian age. The type specimen (Text-fig. 4.1) was initially named Liquidambar gracilis (Lesquereux 1872) and later figured as Aralia? gracilis LESQUEREUX (1878, pl. 39, fig. 1). Wolfe and Wehr (1987) applied this same epithet to specimens from the Eocene of Republic, Washington. Among the numerous specimens from the Clarkforkian Killpecker Creek flora at Rock Springs, Wyoming (Wilf 2002), all are deeply five-lobed, while those from the Tiffanian Joffre Bridge site, Alberta (discussed below; Pigg and Stockey 1991) are three-lobed. Among the many Paleocene leaves that Brown (1962) included as Platanus nobilis NewBerRy, those with five prominent digitate lobes are now treated as M. gracilis, while those with three lobes are treated as Macginitiea nobilis. The leaves vary from entire to serrate, have palinactinodromous venation, and usually long petioles with expanded bases.

\section{Macginitiea nobilis (NEWBERRY) comb. nov.}

\section{Text-figs 5.1-5.3}

1868 Platanus nobilis Newberry, Lyceum Nat. Hist. New York Ann., 9, p. 67. (basionym).

1898 Platanus nobilis Newberry, U. S. Geol. Surv. Monogr., 35, p. 106, pl. 34.

Lectotype, here designated: USNM 1070. Originally figured by Newberry (1898, pl. 34), here refigured as Text-fig 5.2, from near Fort Clark, North Dakota.

The synonymies of Platanus nobilis provided by Brown (1962) and Hickey (1977) included both trilobate and pentalobate leaves but I reserve this epithet for primarily 3-lobed leaves of Macginitiea, whereas the deeply 5-lobed leaves mentioned above belong to $M$. gracilis. Among the originally described specimens of $M$. nobilis from near Fort Clarke, North Dakota, some have only three lobes, and others have five lobes, of which the middle three greatly dominate (Text-fig. 5.1, 5.2).

The Paleocene (Tiffanian) flora of Joffre Bridge, Alberta, is particularly informative, showing a range in leaf morphology for this species, including seedlings documenting early leaf development, as well as mature, trilobate leaves (Pigg and Stockey 1991). Lobes of the lamina vary from mostly entire-margined, to mostly serrate, and a basilaminar lobe extending proximally from the junction of petiole and lamina, is usually absent, but sometimes present (e.g., Pigg and Stockey 1991, pl. 1, fig. 2; Brown 1962, pl. 29, figs 1, 3). Pigg and Stockey (1991) refrained from naming their foliage, but Maslova (2008) concluded that it conformed to P. nobilis and made the argument that this species should belong to Macginitiea: "on the one hand, morphologically similar leaves of Macginitiea and Platanus nobilis (which include transitional forms) are associated with the same reproductive structures and, on the other hand, leaves of P. nobilis, which are assigned to the extant genus, co-occur with inflorescences and infructescences essentially distinguished from those of the plane tree. This probably supports the assignment of these leaf remains to the genus Macginitiea; however, this necessitates further detailed examination." (Maslova 2008, p. 1399). The narrow angle between adjacent primary veins also supports the assignment to Macginitiea. I hereby emend the generic diagnosis of Macginitiea to indicate that the number of lobes on the lamina may vary from 3 to 9 . The number of lobes was not specified in the original diagnosis of Wolfe and Wehr (p. 224, 225 in Manchester 1986).

Also present at the Joffre Bridge locality are nearly complete staminate axes with up to 12 pedicellate heads (Platananthus speirsae PIGG et STOCKEY) having longpedunculate heads with well preserved tricolpate reticulate pollen closely matching extant Platanus pollen morphologically in both SEM and TEM (Pigg and Stockey 1991, pl. 4, 5), plus fruiting axes bearing at least 7 pedicellate heads (Macginicarpa manchesteri PIGG et Stockey). The correlation between Macginitiea foliage, Macginicarpa infructescences and Platananthus inflorescences was also found at Eocene locations in California, Oregon, and Wyoming (Manchester 1986).

Macginicarpa fruiting material consists of a racemose axis bearing numerous pedunculate, globose heads (Text-fig. 4.4), each composed of numerous florets of five apocarpous fruits each (Text-fig. 4.6), differing from extant Platanus by the lack of dispersal hairs on the individual fruits and by a prominent perianth (Manchester 1986). In addition, the staminate flowers, with similarly well-developed perianth, had the unique characteristic that the five stamens of each floret were apically connected by intertwining connective hairs, resulting in the shedding of 5-stamen units, in contrast to the shedding of single stamens in other genera of the family (Manchester 1986). Such dispersed stamen units, now called Macginistemon mikanoides (MACGINITIE) MANCHESTER, were figured from Paleocene sites by Brown (1962, pl. 68, figs 27-29) as "pedicellate flowers or fruits," and by Pigg and Stockey (1991, pl. 4, figs 8, 9) as "isolated group of stamens," and "disagregating stamen inflorescence."

Staminate inflorescences earlier called Sparganium stygium HeER from Seven Mile Creek, Montana (Text-fig. 5.4; Ward 1887, pl. 3, fig. 7, showing at least ten heads on a raceme) also represent Platananthus speirsae. From the same site, the specimens that Brown (1962, pl 14, fig. 5) called Sparganium antiquum (NEWBERRY) BERRY correspond to Macginicarpa manchesteri PIGG et STOCKeY (1991). The same location produced mainly large trilobate leaves of the M. nobilis kind (P1. 41, fig. 1 of Ward 1885b).

Platanites raynoldsii (NEWBERRY) comb. nov.

$$
\text { Text-figs 6.1-6.4 }
$$

1868 Platanus raynoldsi NewBerRY, Lyceum Nat. Hist. New York Ann., 9, p. 69 (basionym); 1898 Platanus raynoldsi NewBerry, U. S. Geol. Surv. Monogr., 35, p. 109 , pl. 35 .

1993 Platanites canadensis McIver et BASINGER, p. 38, pl. 23, pl. 24, figs 1-4.

2008 Ettingshausenia raynoldsii (NEWBERRY) MoISEEVA, p. 324 [excluding all of the Asian figured specimens]. 


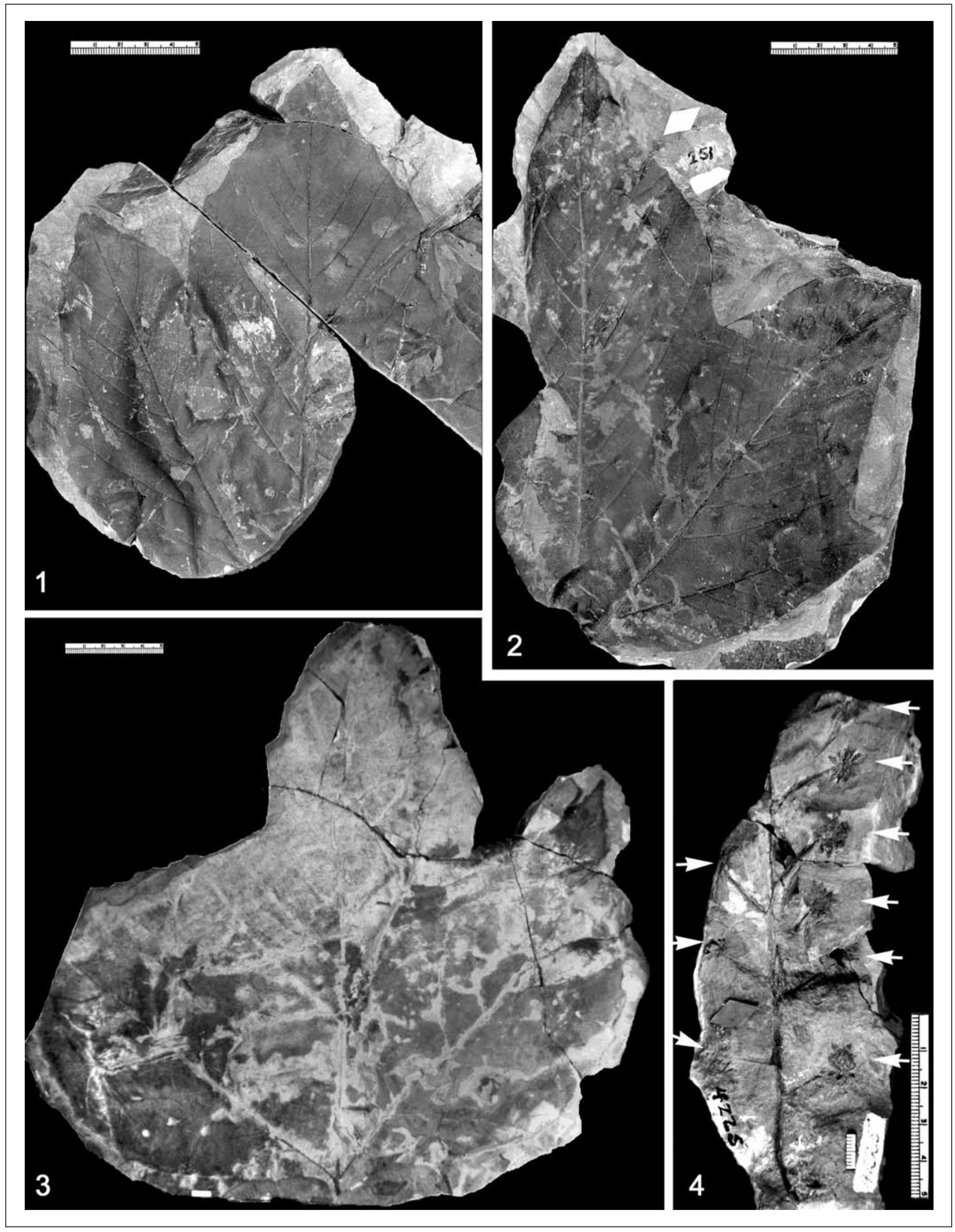

Text-fig. 5. Platanaceae 1-3. Macginitiea nobilis (Newberry) comb. nov. 1. This specimen is labeled as corresponding to Newberry 1898, pl. 50, fig. 1 although it does not match the published drawing exactly. From near Fort Clark, North Dakota, USNM 6964. 2. Lectotype from Newberry (1898, pl. 34), from near Fort Clark, North Dakota; composite picture assembled from images of both counterparts. USNM 1070. 3. Trilobed leaf from Seven Mile Creek, Montana (orig. figured as Platanus nobilis NEwBERRY by Ward 1886, pl. 41, fig. 1). USNM 4093. 4. Platananthus speirsae PIGg et StOckey axis with at least 9 attached pedunculate staminate inflorescences (arrows), Seven Mile Creek, Montana (orig. Ward 1885b, pl. 32, fig. 7), USNM 4225. Scale bars $5 \mathrm{~cm}$. 


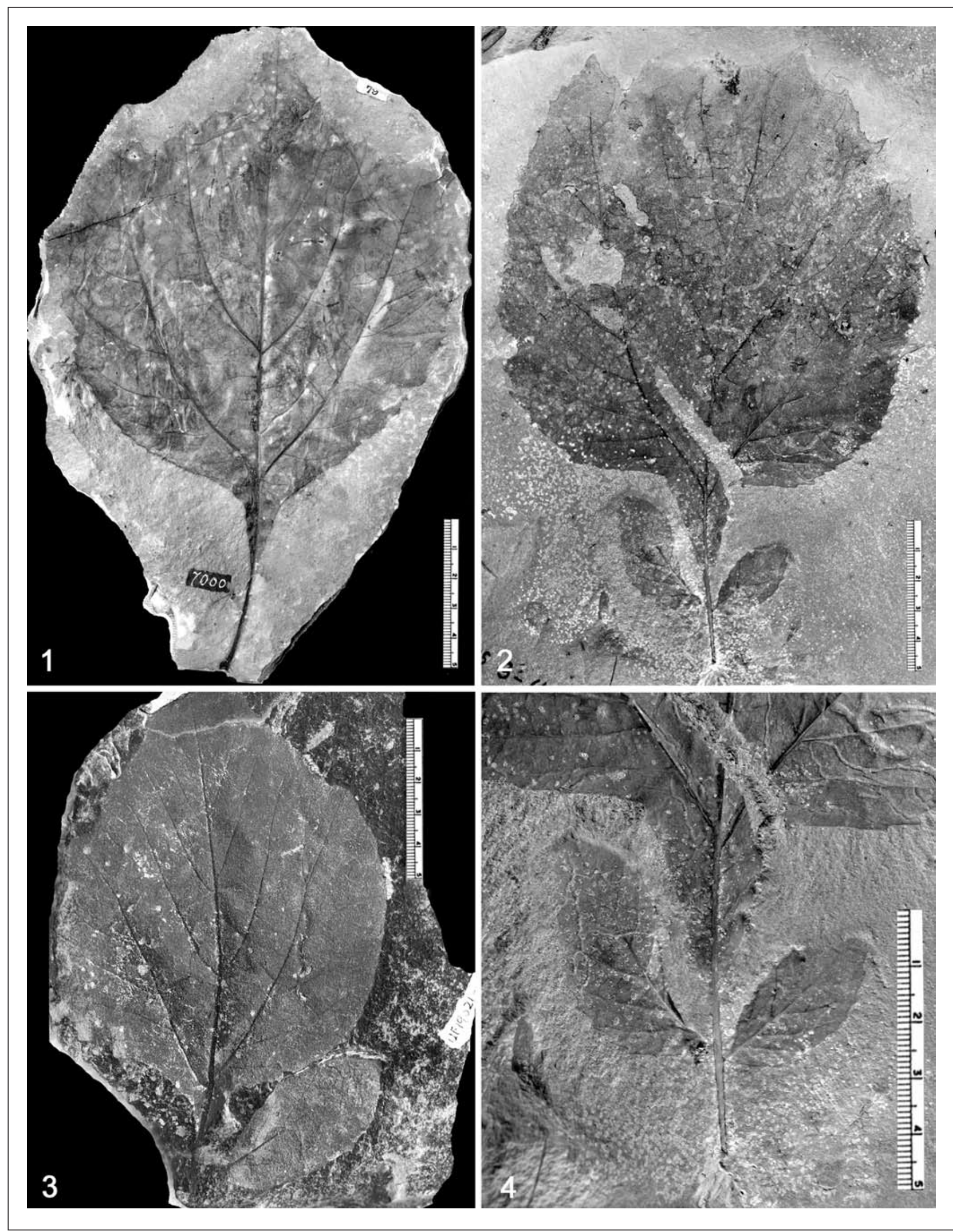

Text-fig. 6. Platanaceae 1-3. Platanites raynoldsii (NEWBERRY) comb. nov. 1. Holotype of Platanus raynoldsii NEWBERRY (1868, 1898), Banks of the Yellowstone River, Montana, USNM 7000. 2. Holotype of Platanites canadensis MCIVER et BASINGER (1993), here treated as synonym of $P$. raynoldsii, showing clearly the position of the lateral leaflets, US 3-66, Ravenscrag Formation, Saskatchewan, Canada. 3. Specimen from Yellowstone Bridge, Miles City, Montana. UF19021-39390. 4. Detail from fig. 2. Scale bars $5 \mathrm{~cm}$. 
McIver and Basinger (1993) illustrated a beautifully complete compound leaf of Platanites from the Paleocene Ravenscrag Formation of southern Saskatchewan, Canada, showing a pair of lateral elliptical leaves attached to the "petiole" of a leaf matching architecturally to the holotype of Platanus raynoldsii (reillustrated here, Text-fig. 6.2). Hence, the petiole of $P$. raynoldsii is actually the rachis of a compound leaf. Because Newberry's species has long been considered to be a simple leaf, as expected for extant Platanus, McIver and Basinger (1993) considered the the Ravenscrag material to be distinct and described it as a new species, Platanites canadensis. They used the generic name based on similar compound platanaceous leaves from Scotland (P. hebridicus Forbes; Crane et al. 1988).

Close comparison between Newberry's holotype specimen of $P$. raynoldsii (Text-fig. 6.1) and the holotype of $P$. canadensis (Text-fig. 6.2) indicates that they are architecturally identical, leading to the conclusion that they are conspecific. Other compound leaves of $P$. raynoldsii have been recovered occasionally in the Late Cretaceous and Paleocene of North America (e.g., specimens figured by Knowlton 1930, pl 45, fig. 10 as Negundo decurrens LESQUEREUX, and by Ellis et al. 2003, fig. 9a as Platanites marginata (LESQUEREUX) K. JOHNSON, but usually the petiole/rachis lacks lateral leaflets, giving appearance that "they leaves" were simple. We do not know whether this is due to deciduousness and/or damage prior to deposition, or if $P$. raynoldsii might have been variable, producing both simple and compound leaves on the same individual (perhaps a difference between seedling and mature leaves, for example). Nevertheless, the tendency to produce compound leaves distinguishes this species from all extant species of Platanus, and justifies its assignment to the extinct genus, Platanites.

Prior to the realization that this species represents a compound-leaved plant, Brown (1962), adopted the name Platanus raynoldsii (and included Newberry's $P$. haydeni in synonymy), for most weakly trilobate platanaceous leaves from the Paleocene of the Rocky Mountains and Great Plains region and provided a thorough synonymy of earlier published specimens from the works of Newberry, Lesquereux, Ward and Knowlton. The same epithet was applied to similar laminae from the late Cretaceous and Paleocene of Far Eastern Russia (Krassilov 1976). Based mainly on her investigations of the far eastern Russian material, Moiseeva (2008) established a new combination, Ettingshausenia raynoldsii, for the species, applying the fossil-genus name Ettingshausenia STIEHLER (1857). However, Ettingshausenia is believed to be a simpleleaved genus. It is possible that the genus Ettingshausenia is appropriately applied to the Asian fossils, but a different specific epithet is needed from that applied to the North American species considered here. It is not appropriate to use the name Ettingshausenia in the case of the type material of $P$. raynoldsii NEWBERRY, which conforms instead to Platanites ForBES.

\section{Platanites marginata (LESQUEREUX) K. JOHNSON}

1873 Viburnum marginatum LESQUEREUX, p. 395; 1878 p. 223, pl 37, fig. 11, pl. 38, figs 1-4. (basionym).

For synonymy see Johnson (1996).

The compound-leaved plant formerly called Cissus marginata (LESQUEREUX) BROWN was recombined as
Platanites marginata (LESQUEREUX) K. JOHNSON (1996). In addition to the complete compound-leaved specimens illustrated by Brown (1962), excellent examples are known from the uppermost Cretaceous Hell Creek Formation (Johnson 1996). Brown (1962, p. 65) noted "The leaves of $P$. raynoldsii are in general not strongly lobed, and they resemble the terminal leaflets of Cissus marginata (LESQUEREUX) BROWN [here treated as Platanites marginata] so closely that separation of the two species, especially when they are poorly preserved, is virtually impossible". It is possible that $P$. marginata and $P$. raynoldsii are conspecific-if so, then the older epithet, raynoldsii, takes priority. However, the type specimen of Platanites marginata have a narrower angle between primary and secondary veins than is typical of $P$. raynoldsii.

Although compound leaves do not occur in extant Platanus, some of the extinct Cretaceous and Tertiary genera of Platanaceae were indeed compound. Platanites is recognized by its trifoliately compound leaves. Extinction of Platanites apparently occurred sometime after the middle Eocene; the youngest known occurrences are from the Eocene of Kisinger Lakes, Wyoming (MacGinitie 1974, pl. 14, fig. 1), and John Day Gulch, Oregon (UF 27869, 27870 , loc. 265). A related extinct genus, Erlingdorfia, with more distinct lobing of the trilobed terminal leaflet and markedly asymmetrical bilobed lateral leaflets, is apparently confined to the Late Cretaceous (Johnson 1996).

\section{“Platanus” bella (HEER) Z. KVAČEK, MANCHESTER et S.X. GuO}

In addition to the above platanaceous taxa recognized by Brown (1962), Hickey (1980) found compound leaves that he referred to as Debeya sp. from the Paleocene of Montana. KVAČEK et al. (2001) showed that these trifoliate leaves match, in epidermal as well as architectural characters, those from the Paleocene of Greenland and China known as Platanus bella. Like Platanites, the leaves were compound, but in this species the leaflets were elliptical, without any lobation. Thus they resemble the lamina shape of extant Platanus kerrii, but that species, like all extant Platanus species, has only simple leaves. Cuticular investigations have revealed epidermal anatomy in this species conforming with extant Platanus (Kvaček et al. 2001). Although Kvaček et al. placed the leaves in an extinct subgenus of Platanus, named Glandulosa, it can be argued, based on the current concept of ranks within the family, including Macginitiea, and Platanites as genera distinct from Platanus, that this taxon also requires separate generic status. Kvaček et al. (2001) explained, however, that names previously considered, including Dewalquea and Debeya would be inappropriate for this species due to differences from the type material.

\section{Dyrana flexuosa (NEWBERRY) GOLOVNEVA}

This species is based on leaves found initially in the late Paleocene or early Eocene Chuckanut Formation of coastal Washington, and subsequently recognized to have been distributed in the Rocky Mountain region, treated as Dicotylophyllum flexuosa (NEWBERRY) J. WOLFE (1966). Golovneva (1994b) established the genus Dyrana based on specimens from the Paleogene of the Koryak Highlands of 
NE Russia, and subsequently transferred the North American species to the same genus (Golovneva, L. B. 2000, Budantsev and Golovneva 2009). Budantsev and Golovneva also illustrated numerous examples of $D$. flexuosa from the early Paleocene Barensburg flora of Spitsbergen. The leaves are elliptical to ovate, with pinnate craspedodromous secondary veins and teeth with rounded sinuses. As mentioned above, these leaves were treated as Quercus sullyi NEWBERRY by Brown (1962) and Meliosma longifolia (HEER) HickeY 1977. The attribution to Platanaceae is supported by glandular teeth with rounded sinuses, petioles with expanded bases, and the orthogonal pattern of higher order venation, but epidermal characters remain unknown and associated reproductive structures have not been clearly demonstrated.

\section{Trochodendraceae}

\section{Nordenskioeldia borealis HEER}

Nordenskioeldia borealis HeER (Brown 1962, pl. 67, figs $13,45)$ was widely distributed in the late Cretaceous and Paleocene of the Northern Hemisphere and is represented at numerous localities of the Rocky Mountains and Great Plains region. This genus and species was reviewed in detail by Crane et al. (1991) and Wang et al. (2009). It is known from infructescences, whole fruits, dispersed fruitlets, and shed seeds. The seeds, which were figured and described as "seeds with papillose inner surface" by Brown (1962, P1. 67, figs 9, $10,14-16,22,23)$, are known to belong to this extinct genus because one is shown dispersing from a fruitlet in figs 28, 29 of Crane et al. (1991), and they are preserved in situ with fruits of the silicified specimens from Almont, North Dakota (Crane et al. 1991, figs 16, 28). Nordenskioeldia associates with the same kind of extinct leaf in the Late Cretaceous to Paleocene of the Northern Hemisphere, and even in the Miocene refugial populations (Manchester et al. 1991). Leaves of Zizyphoides SEWARD et CONWAY in the Paleocene of North America have been called Z. flabella (NEWBERRY) Crane, Manchester et Dilcher; the holotype is from the Chuckanut Formation of west coastal Washington.

\section{Cercidiphyllaceae}

Text-figs 7, 8

Brown (1939b, 1962) called attention to the co-occurrence of leaves, fruits, and winged seeds resembling extant Cercidiphyllum at numerous Paleocene and Eocene sites in North America. He assigned the fossils to the extant genus, collectively as Cercidiphyllum arcticum (HEER) R. W. BROwN although he noted that the fruits differ from those of extant species in the genus in having more prominent transverse and diagonal striations, and are borne on racemose rather than clustered inflorescences (e.g., Text-fig. 7.4). In a comparative study of similar leaves from the Paleocene of England, Crane (1984) applied separate fossil-generic names, Trochodendroides BERRY for leaves and Nyssidium HEER for the fruits. The same kind of infructescences were documented in detail from the Paleocene of Asia (Feng et al. 2000). The Joffre Bridge locality of Alberta yielded such leaves, fruits, and seeds in association with both pistillate and staminate inflorescences, twigs showing phyllotaxy, and young seedlings, providing an especially complete reconstruction of the plant named Joffrea spiersii (Crane and Stockey 1985).

Brown had inadvertently included multiple kinds of leaves in his concept of fossil Cercidiphyllum arcticum foliage (Hickey 1977). Some, usually with evenly serrate margins, belong to Trochodendroides and presumably correspond, as he surmised, with the fruits he described and illustrated (ie., Nyssidium arcticum (HeER) ILJINSKAYA sensu Crane 1984). Other leaves (e.g., Brown 1930b, plate 53, figs 3-5) with irregular crenations and/or sometimes entiremargins are consistently found in co-occurrence with fruits of another extinct fruit genus, Nordenskioeldia HeER (Crane et al. 1991). These were subsequently treated as "Cocculus" flabella (Newberry) J. Wolfe (1966), Menispermites parvareolatus HICKEY (1977), and then, using the oldest available generic name, collectively transferred to Zizyphoides flabella (Newberry) Crane, MANChester et DiLCHER (1991). These leaves are discussed herein along with Nordenskioeldia borealis. Although the organs have not been found in mutual attachment, they co-occur at numerous sites of late Cretaceous and Paleocene age throughout the Northern Hemisphere, and even in Miocene refugial populations (Manchester et al. 1991).

Even from the first recognition of the species described as Populus arctica by HeER from Greenland, the species concept included variation ranging from entire-margined and irregularly crenate leaves now thought to coincide with Nordenskioeldia fruits, as well as those with more regularly spaced crenations believed to represent the Nyssidium plant. As noted by Budantsev and Golovneva (2009), the lectotype of Populus arctica HeER (basionym of Trochodendroides arctica (HEER) BERRY) resembles the leaves treated by Crane et al. (1991) and Manchester et al. (1991) as Zyziphoides. Thus, it is possible that the type species of Trochodendroides arctica (HEER) BERRY coincides with the Nordenskioeldia plant, rather than with the Nyssidium plant to which it has often been associated. To avoid further confusion, I hesitate to use the epithet arctica, based on Greenland material, for the North American taxa representing this group.

Trochodendroides genetrix (NEWBERRY) comb. nov.

Text-figs 7.1-7.3

1868 Populus genetrix NewBerry, Lyceum Nat. Hist. New York Ann., 9, p. 64; 1898 U. S. Geol. Surv. Monogr., 35, p. 44, pl. 27. fig. 1 [Basionym].

1939a Cercidiphyllum arcticum (HeER) Brown p. 492494, pl. 53, figs 1,6 , P1. 54, figs $1-3$, 7; P1. 56, fig. 1 .

1962 Cercidiphyllum arcticum (HEER) Brown p. 70, pl. 38, figs 1, 8, 14, 16.

1977 Cercidiphyllum genetrix (NEWBERRY) HICKEY p. 124, pl. 22, figs 1, 2, 4-7; pl. 23, fig. 2, pl. 24 fig. 1.

A recently recovered twig with attached leaves (Text-fig. 7.1) shows the great variation of leaf from elliptical to ovate to obovate, and fan-shaped forms, and serration ranging from fine to coarse, proving that they indeed represent one species. This leads to the conclusion that the leaves called Cercidiphyllum genetrix (NEWBERRY) HICKEY, Trochodendroides serrulata (WARD) J. WOLFE (See Hickey 1977 for 


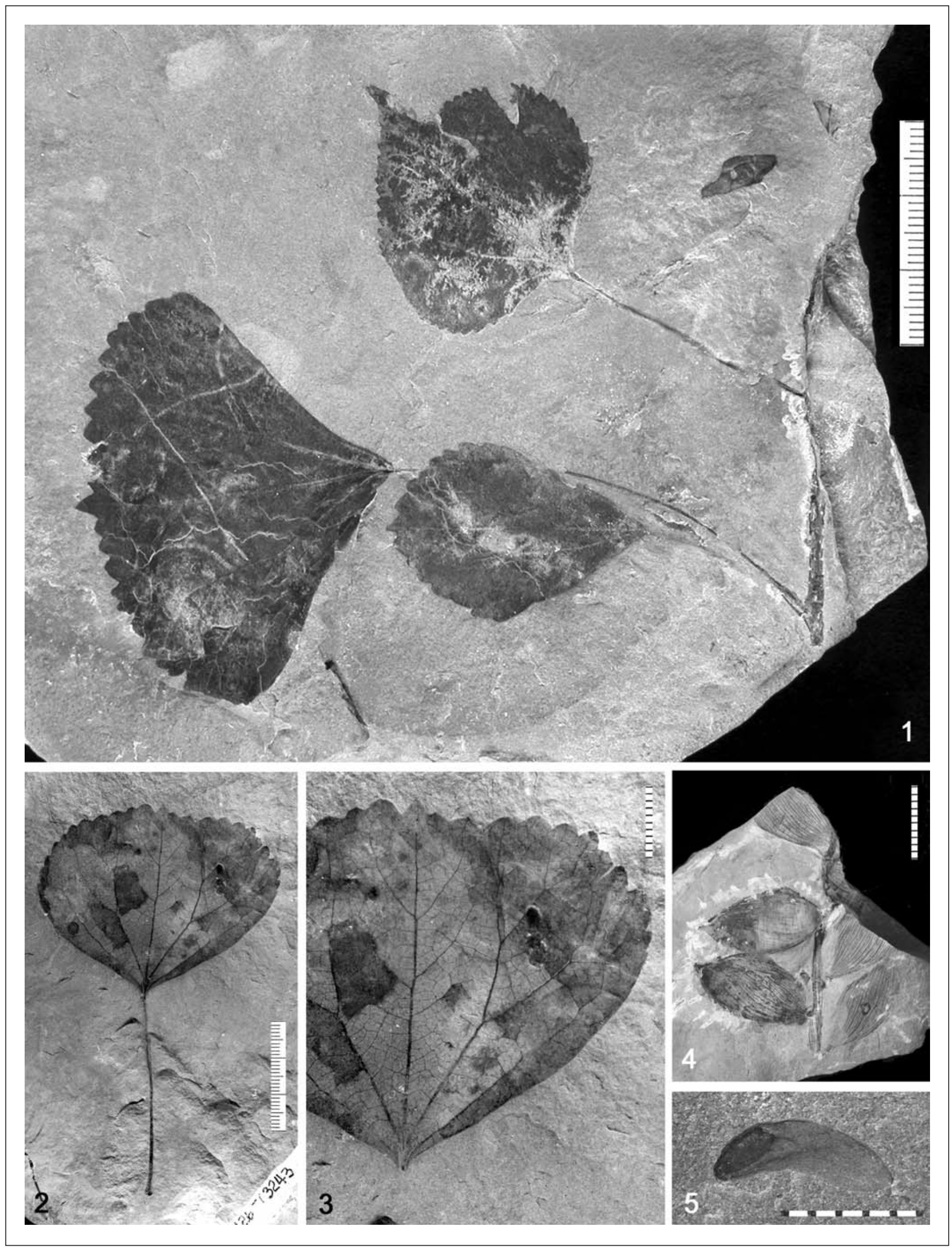

Text-fig. 7. Cercidiphyllaceae 1-3. Trochodendroides genetrix (NEWBERRY) comb. nov. and associated reproductive structures $(4,5)$ from Killpecker Cr., Rock Springs, Wyoming (UF loc. 18126). 1. Twig with three attached leaves, showing variation in leaf shape and serration; composite figure assembled from images of both counterparts, UF 35427. 2. Complete leaf including petiole, UF 13243 . 3. Same as 2, detail of venation. 4. Nyssidium arcticum (HEER) ILJINSKAYA fruits on an incomplete axis, UF 35454. 5. Dispersed winged seed, UF 35479. Scale $=3 \mathrm{~cm}$ in 1,$2 ; 1 \mathrm{~cm}$ in 3,$4 ; 0.5 \mathrm{~cm}$ in 5 . 
review) and many of those formerly treated by Brown as Cercidiphyllum arcticum (syn. Trochodendroides arctica) represent variation in a single species. Because these leaves do not match the lectotype of T. arctica from Greenland, it seems prudent to recognize this widespread and common type of foliage from the North American Paleocene under the new combination Trochodendroides genetrix. The generic name, Trochodendroides BERRY, is based on a similar, but finely serrate, leaf from the Cretaceous Dakota Formation of Nebraska.

\section{Archeampelos acerifolia (NEWBERRY) MCLVER et BASINGER}

\section{Text-fig. 8}

1868 Populus acerifolia Newberry, p. 65; 1898, p. 37, pl. 28, figs 5-8 (Basionym)

1962 Ampelopsis acerifolia (Newberry) Brown, 1962, [part], p. 78, pl. 51, figs 1, 3, 4, 8, 13, 16, 17.

1993 Archeampelos acerifolia (Newberry) McIver and Basinger, 1993, p. 47 (but not their figured specimens)

Lectotype, designated here: USNM 551, the leaf originally figured as plate 28 , fig. 5 by Newberry (1878), here refigured as Text-fig. 8.1, 8.2.

Leaves of this species vary from wide-ovate to trilobate with regularly spaced rounded glandular teeth and have moderately long petioles. Both Brown (1962) and McIver and Basinger (1993) assigned this species to Vitaceae. Despite similarities to Vitaceae, including the tendency for shallowly trilobate leaves, the architectural similarities with Trochodendroides are stronger. The teeth are rounded and somewhat larger than those typically seen in Trochodendroides arcticum but have the same morphology and gland position. At some localities, for example, Bison Basin, Wyoming, the leaves co-occur with an unnamed species of Nyssidium having relatively large fruits. The association of Nyssidium infructescences with leaves of Trochodendroides at some sites, and with leaves of Archeampelos at other sites, suggests that the plants producing these two leaf types were closely related.

McIver and Basinger (1993) used a broad species concept for this taxon, accommodating specimens of "Populus" nebrascensis NEWBERRY as well as "Populus" acerifolia Newberry. However, Peppe (2009) documented three morphologically distinct species of Archeampelos with different stratigraphic ranges. Although McIver and Basinger's combination Archeampelos acerifolia, based on Newberry's original material from Fort Union, North Dakota (Text-Fig. 8), applies to many Paleocene leaf populations, for example those studied by Gemmill and Johnson (1997) from Bison Basin, Wyoming, it is inappropriate for the specimens that McIver and Basinger (1993) illustrated from the Ravenscrag Formation. Although the required new combination has not yet been published, the Ravenscrag population conforms to another widespread species of the same genus that includes the type specimen of "Populus" nebrascensis NEWBERRY (1868). PEPPE (2009) documented useful morphological characters for distinguishing three species of Archeampelos that each have distinctive stratigraphic ranges in North America.

\section{Hamamelidaceae}

The leaf called Hamamelites inaequalis (NEWBERRY) R. W. BROWN was considered to be similar to extant Hamamelis virginiana L, but Brown (1962) noted that neither fruits nor seeds have been found to confirm the identification. The genus Hamamelites was erected by Saporta $(1865,1868)$ for leaves from the Paleocene of Sezanne, France. The leaves illustrated by Brown also resemble the extinct platanaceous genus, Platimeliphyllum Maslova 2002.

The infructescence illustrated by Brown (1962) as a "longitudinal hollow studded with bilobed projections" (pl. 65 , fig. 44), seems likely to represent an infructescence of Hamamelidaceae. Fruiting capsules of this family will appear to have bilobed projections due to the persistence of paired styles. Unequivocal silicified fruits and of Hamamelidaceae, and their explosively dehiscent seeds, are known from the Paleocene of Almont, North Dakota (Crane et al. 1990, Benedict et al. 2008).

Brown (1962) described Liquidambar dakotense R. W. BROWN based on winged seeds from the Anarchist Hill site in South Dakota, but he did not provide a clear justification for the generic assignment. Liquidambar seeds have a raphe along the median line of the wing, which is not present in this fossil. The other genus that Brown included in discussion of this fossil was Exbucklandia. That extant genus has seeds that are indeed very similar to this fossil. However, the seeds also fall within the range of variation of those Brown had earlier considered to be produced by Cercidiphyllum articum. In my opinion, the seed represents Nyssidium arcticum and is a part of the Trochodendroides genetrix plant.

\section{Cucurbitaceae}

\section{Cucurbitaciphyllum gen. nov.}

Diagnosis. Leaves palmately trilobed, petiole narrow, not swollen at junction with lamina. Lamina base cordate, lobe apices acute; lobal sinuses rounded, margins of the three main lobes with smaller lobes and teeth. Venation actinodromous with a primary vein directed into each major lobe. Secondary veins pinnate, camptodromous to semicraspedodromous, sometimes interconnecting to form an intramarginal vein in lower portion of the lobes. Lower surface of leaf covered by closely spaced trichomes.

Ty p e species. Cucurbitaciphyllum lobatum (KNOwLTON) comb. nov.

Etymology. The generic name combines the roots, Cucurbitac-, referring to the family Cucurbitaceae, which has similar leaves among extant genera, and -phyllon (Gr. = leaf).

\section{Cucurbitaciphyllum lobatum (KNOWLTON) comb. nov.}

$$
\text { Text-figs 9.1-9.4 }
$$

1924 Aralia lobata Knowlton, U. S. Geol. Surv. Prof. Paper 134, p. 93, pl. 17, figs 1, 2 (Basionym)

1962 Vitis lobata (KNOWLTON) R. W. BROwn, p. 82, figs $3,7,10$. 


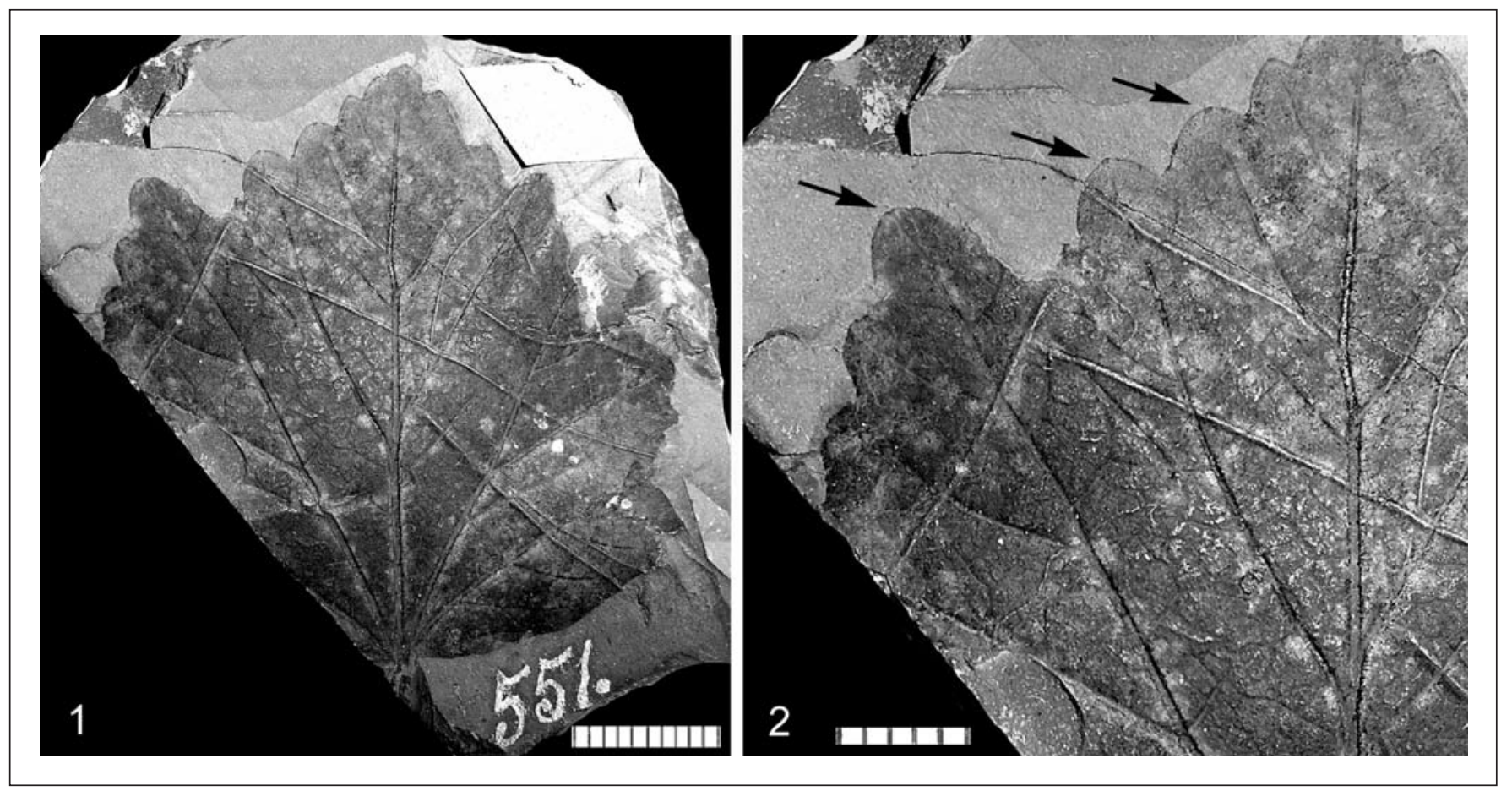

Text-fig. Fig. 8. Cercidiphyllaceae. Archeampelos acerifolia (Newberry) MCIver et BASINGEr. 1, 2 Lectotype, from Fort Union, North Dakota. 1. The leaf originally figured as plate 28, fig. 5 by Newberry (1878). USNM 551. 2. Detail of marginal dentition, showing a small gland at each tooth apex (arrows). Scale $=1 \mathrm{~cm}$ in $1 ; 0.5 \mathrm{~cm}$ in 2.

Lectoype designated here: USNM 36675, fig. 1 of Knowlton 1924.

Emended diagnosis. Leaves palmately trilobed, 3.5 to 15 $\mathrm{cm}$ long, 5 to $13 \mathrm{~cm}$ wide. Petiole narrow, not swollen at junction with lamina. Lamina base cordate. Lobes obovate, with smaller lobes and teeth along the margins; lobe apices acute. Sinuses of lobes and teeth usually rounded. Venation actinodromous, with a primary vein in each lobe, that of the central lobe symmetrically placed, those of the lateral lobes, placed asymmetrically, closer to the proximal margin. Often with an strong secondary or subprimary vein, arising near the base on abaxial side of the lateral primaries and feeding to a basal large tooth or small external lobe. Secondary veins pinnate in 7 to 9 pairs per lobe, camptodromous to semicamptodromous; lower pairs arising at 80 to $90^{\circ}$ from the midvein and interconnecting to form an incomplete intramarginal vein (where the margin is untoothed); upper secondaries arising at narower angles (30-45 ), craspedodromous where teeth are present. Intersecondary veins common. Tertiary veins percurrent to reticulate. Lower surface dotted impressions of numerous hair-like trichomes. Simple trichomes are seen as densely spaced protrusions on impression surfaces representing the lower surface of the lamina.

Jack Wolfe (cited in Raven and Axelrod 1974, p. 569) determined that Vitis lobata (KNOwLTON) BROwN (1962) clearly belongs to the Cucurbitaceae, but the characters leading to his conclusion were not stated. Wolfe's identification is supported by the palmate lobing, scattered teeth, rounded lobal sinuses, partial intramarginal vein and simple trichomes scattered over the lamina surface. This architectural pattern occurs in more than one modern genus of the family, including Kedrostis, Melothria, and Zehneria. Accordingly, a new genus is established here to accommodate this species. This is significant because the fossil record of Cucurbitaceae is poorly known.

\section{? Fagaceae}

Brown attributed several leaf types to Fagaceae, including Castanea intermedia LESQUEREUX, Quercus asymmetrica Trelease, Q. greenlandica HeER, Q. macneilii R. W. Brown, Q. sullyi NEWBERrY, and Q. yulensis R. W. Brown. However, the affinities, even to the family level, are questionable as no unequivocal cupulate fruits of Fagaceae have been recovered. Quercus greenlandica was subsequently transferred to Fagopsiphyllum groenlandicum (HEER) MANCHESTER 1999. Q. yulensis also appears related to Fagopsiphyllum differing mainly by its more prominent teeth.

Leaves that Brown treated as Quercus sullyi NEWBERRY were subsequently treated as Dicotylophyllum flexuosum (NeWBerry) J. Wolfe (1966) and then Meliosma longifolia (HeER) Hickey (1977), but most recently, they have been assigned to the extinct genus Dyrana Golovneva, as discussed herein under Platanaceae.

\section{Betulaceae}

Brown (1962) recognized two kinds of foliage assigned to the Betulaceae: Betula stevensonii LESQUEREUX, and Corylus insignis HEER. Betula stevensonii, established based on leaves from the Evanston Formation of southwestern Wyoming, might be Betulaceae, but the fine serration appears simple, rather than compound-unusual for Betula and for the family. The type locality is literally mined out and now occupied by a Walmart parking lot and adjacent lake. Although the attribution to Betulaceae may be correct, the 


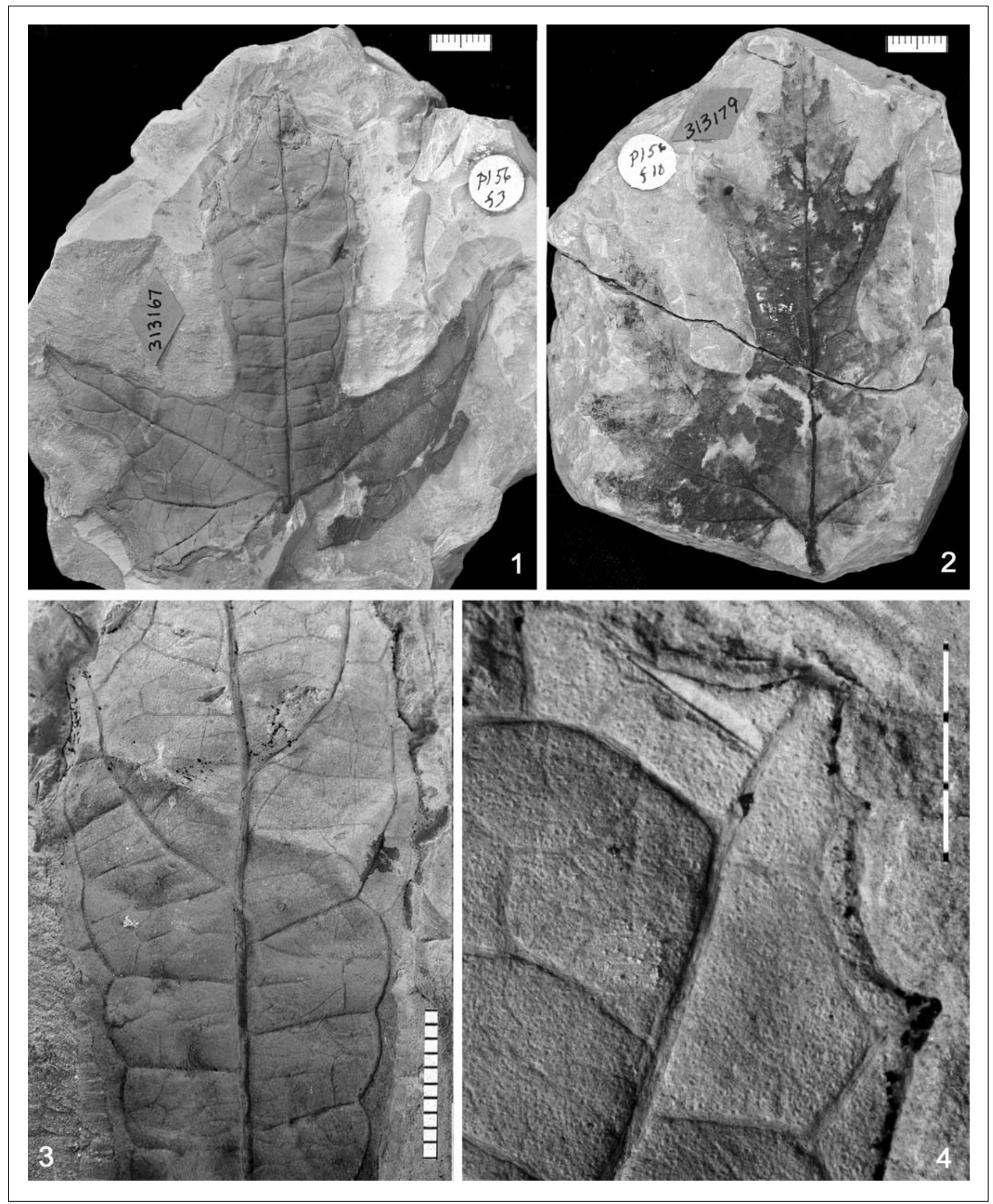

Text-fig. Fig. 9. Cucurbitaceae 1-4. Cucurbitaciphyllum lobatum (KNowlton) comb. nov. Specimens from Shirley Canal, Montana, USGS loc. 8519. 1. Trilobate leaf, with rounded lobal sinues, and entire to serrated margin. USNM 313167. 2. Leaf with pronounced secondary lobes and cordate base, USNM 313179. 3. Detail of central lobe from fig. 1. 4. Higher magnification, showing abundant trichome impressions. Scales $=3 \mathrm{~cm}$ in $1-3 ; 3 \mathrm{~mm}$ in 4 .

assignment to Betula is questionable. None of the distinctive trilobed infructescence bracts of Betula have been observed in this or other Paleocene sites of the Rocky Mountains or
Great Plains region, but they are frequently found with fossil leaves of Betula leopoldae from the Eocene of Washington (Crane and Stockey 1987). 


\section{Palaeocarpinus joffrense SUN et STOCKEY}

Infructescences and spiny-bracted fruits of the extinct betulaceous genus Palaeocarpinus CRANE were described by Brown as bur-like objects. The examples figured by Brown (1962 pl. 67, figs 39-42, 47) and Crane (1989, fig. 6.5F) correspond to Palaeocarpinus joffrense Sun et STOcKey which was described based on infructescences and fruits from the Paleocene of Alberta (Sun and Stockey 1992) and the late Paleocene-early Eocene Storvola flora of Spitsbergen (Golovneva 2002, Budantsev and Golovneva 2009). Leaves that Brown called Corylus insignis were likely produced by the same plant. Brown (1962) used the name Corylus insignis HEER based on the specimens Heer (1871) identified from Greenland. Golovneva (2002) showed that the epithet malmgrenii (from Tilia malmgrenii Heer 1868 from the Eocene of Spitsbergen) takes priority for such leaves and observed that the "American leaves are morphologically identical to the leaves from Spitsbergen, associated with fruits of the same species." The genus Corylites has been considered appropriate for leaves of this kind in association with Palaeocarpinus (Manchester and Guo 1996), but Golovneva (2002) argued in favor of the genus Craspedodromophyllum CRANE. Golovneva provided a new combination Craspedodromophyllum malmgrenii (HeER) Golovneva, using the fossil-genus that Crane had established for foliage associated with Palaeocarpinus fruits from the Paleocene Reading Beds of England. Thus, $C$. malmgrenii applies to the Corylus-like leaves associated with Palaeocarpinus joffrense (i.e., leaves Brown identified as Corylus insignis) known from several localities in North Dakota, Montana and Wyoming as well as Alberta and Spitsbergen.

Other species of Palaeocarpinus include fruits with very spiny bracts known from two localities in North Dakota (P. dakotensis Manchester, PigG, et CRAne 2004), and those with mostly entire-margined bracts from some sites in southwestern Wyoming ( $P$. aspinosa MANCHESTER et CHEN 1989). These all co-occur with Corylus-like leaves that can be attributed to Corylites or Craspedodromophyllum, although formal specific epithets have not been proposed. As noted by Brown (1962), the single nut specimen that he assigned to Corylus was surprisingly small in comparison with extant Corylus nuts. It may have been either a nut of Palaeocarpinus, or a seed of Taxus, both of which have a longitudinally striate surface and truncate base where the involucre (Corylus) or aril (Taxus) attached.

Staminate catkins commonly associated with Palaeocarpinus contain Corylus-like pollen (Manchester and Chen 1996; Manchester et al. 2004; Sun and Stockey 1992). Given the similarities of the leaves and pollen to that of extant Corylus, and the relatively minor differences between Palaeocarpinus and extant Corylus it seems clear that Palaeocarpinus was very close to extant Corylus, possibly plesiomorphic within the same lineage.

An additional betulaceous element common in the Paleocene of Wyoming, not treated by Brown, was the extinct genus Cranea, known from the Bighorn and Powder River basins of Wyoming, consisting of elongate infructescences with some similarity to modern Ostryopsis. Leaves associated with Cranea are more elongate than those of
Corylites malmgrenii and have more closely spaced parallel secondary veins (Manchester and Chen 1998).

\section{Juglandaceae}

The Juglandaceae are represented by leaves and fruits in the Paleocene floras reviewed by Brown (1962). Pollen of the family is also well represented and useful in biostratigraphy (Nichols and Ott 1978, 2006). Brown (1962) used the broad concept of the extant genus Pterocarya (including Cyclocarya), and accordingly attributed two species to Pterocarya that are now treated as the distinct genera Cyclocarya, and Polyptera MANCHESTER et DiLCHER (1982, 1997).

\section{Cyclocarya hispida (R. W. BROWN) comb. nov.}

1962 Pterocarya hispida R. W. Brown U. S. Geol. Surv. Prof. Pap.; 1971 WATT. Taxon, 20 (4), p. 640 (Basionym).

Lectotype designated by Watt (1971): USNM 167492 (Brown 1962, pl. 18, fig. 11).

Circular winged fruits and compound foliage that Brown called Pterocarya hispida are now treated as Cyclocarya, a genus now endemic to central China. The fruits were renamed Cyclocarya brownii MANCHESTER et DILCHER (1982; Manchester 1997). The leaves were not formally renamed, but should not be accepted as representing extant Pterocarya. I therefore supply here the new combination, Cyclocarya hispida (R. W. BROWN) comb. nov. Associated dispersed pollen, usually triporate and lacking special exinous thinning patterns (Manchester 1987) goes by the name Momipites wyomingensis NicHOLs et OTT.

\section{Polyptera manningii MANCHESTER et DILCHER}

Fruits and foliage that Brown called Pterocarya glabra R. W. BRown are now treated as an extinct genus. The fruits were described as Polyptera manningii MANCHESTER et DILCHER. The foliage, found in consistent association at more than a dozen sites in Wyoming and Montana (plus a recently discovered site in central Colorado-Baptist Road locality, DMNH loc. 2177) is treated as Juglandiphylloides glabra ( $\mathrm{R}$. W. Brown) MAnchester et Dilcher. The leaves have five to seven leaflets. One of the distinctive features of this species is the long petiolules that can be $2.5-10 \mathrm{~mm}$ long, in contrast to the subsessile leaflets of other juglandaceous leaf types known from these Paleocene deposits. Associated catkins yield triporate isopolar pollen of Maceopolipollenites annellus (Nichols et OTT) MANCHESTER et DilChER (referred to Momipites annellus by Nichols and Ott 1978). Polyptera is the oldest of the juglandaceous fruit genera known from the Rocky Mountain region, being known from Puercan and Torrejonian sites, and not found in co-occurrence with Cyclocarya or Juglandicarya. J. glabra leaflets, which are serrate to rarely entire-margined, are readily distinguished from other Paleocene Juglandaceae by the long petiolules.

\section{Juglandicarya simplicarpa MANCHESTER}

1987 Juglandicarya simplicarpa MANCHESTER p. 14, fig. 4. 
Juglandicarya simplicarpa MANCHESTER fruits are known from several localities in the Rocky Mountains region. These are molds and casts of a relatively large, wingless nut 14 to $20 \mathrm{~mm}$ in equatorial diameter. The locule casts show typical juglandaceous morphology, but have only a primary septum without a secondary septum or other intrusions. These casts and molds resemble the permineralized fruit of Juglandicarya cantia REID et CHANDLER from the London Clay flora, but the internal anatomy of that fruit type has not been documented to show whether it is more closely related to Carya or to Juglans. Based on the common co-occurrence with Caryapollenites pollen (Nichols and Ott 1978), and apparent absence of Juglans like pollen, we infer that these fruits may have belonged to the Hicorieae tribe of Juglandaceae (Manchester 1987).

\section{"Carya" antiquorum NEWBERRY}

Newberry's hickory, "Carya" antiquorum NEWBERRY (1898), was based on leaflets recovered from a site at the mouth of the Yellowstone River. The original type specimens are accepted as representing Juglandaceae, but most of those included in the species by Brown (1962) and those described by Hickey (1977) have been shown to represent Aesculus hickeyi MANCHESTER, with palmately, rather than pinnately, compound foliage (Manchester 2001). The syntypes of " C." antiquorum, isolated leaflets originally depicted with drawings, were illustrated photographically by Manchester (2001, fig. 5A, B, E) for contrast with leaflets of Aesculus. Another specimen from a site near the type locality, with rachis bearing paired scars of detached lateral leaflets, indicates that this species was imparapinnate (Manchester 2001, fig. 5C, D). The more precise affinities of Newberry's "C." antiquorum have not been determined. The leaflets lack gland impressions thus distinguishing them from Cyclocarya hispida, but this could be a preservational difference from site to site. There is a good possibility that "Carya" antiquorum coincides with the plant that produced Juglandicarya simplicarpa fruits.

The generic and familial assignments of "Juglans" berryana (KNOWLTON) R. W. BROWN and "Juglans" taurina R. W. BROWN and are questionable. The first of these was initially described by Knowlton (1924), as Dryophyllum berryana KNOWLTON and as Magnolia angustifolia NEWBERRY (based on counterpart impressions of the same leaf specimen). "J." taurina has asymmetrical broad-ovate, entire-margined laminae with well-impressed transverse tertiary veins and appear to represent leaflets, but in the absence of additional diagnostic characters, it is not possible to rule out affinities with numerous other families having compound leaves.

\section{? Rosaceae}

Brown (1962) recognized four species of Prunus, i.e., P. coloradensis Knowlton, P. careyhurstia R. W. BRown, P. maclearnii BERRY, and P. perita R. W. BROWN, and one species of fruit, Prunus corrugis R. W. Brown. As stated by Wolfe (1977) "Brown (1962) has attributed some leaves from the Rocky Mountain Paleocene to Prunus, but none of these leaves has the acropetiolar glands or glandular teeth characteristic of Prunus." There are many extant species of Prunus that do not display the acropetiolar glands, but without that character, it is difficult to distinguish this genus from others in the Rosaceae and other families, which leaves these identifications in some question. The fruits called Prunus corrugis R. W. BROWN were subsequently shown to represent Icacinaceae and were transferred to Icacinicaryites corruga by Pigg et al. (2008). A new fossil genus, Prunites, was established based on one of Brown's species, resulting in the new combination, Prunities maclearnii (BERRY) MCIVER et BASINGER. McIver and Basinger (1993) agreed that it is close to extant Prunus, but noted the details of fine venation and fruits are not known.

\section{Ulmaceae}

Ulmus-like leaves were assigned by Brown (1962) to three different genera and species: Planera microphylla NEWBERRY, Ulmus rhamnifolia WARD and Zelkova planeroides (WARD) R. W. BROWN. The familial assignment is believed to be correct because of the distinctive combination of characters including asymmetrical lamina, short thick petioles, blunt, simple to doubly compound, non-glandular teeth, and percurrent tertiary venation. It is puzzling, however, that no fruits of Ulmaceae have been identified in association with these leaves at any of the Paleocene sites in North America or Asia (Manchester 1989, and subsequent observations). The fruits that Brown attributed to Ulmus rhamnifolia were subsequently shown to represent Polygonaceae and later identified as Polygonocarpum curtisii MANChester et O'LEARY (Brown 1962, pl. 24, fig. 17) and Podopterus antiqua MANCHESTER et O'LEARY (Brown 1962, pl. 24, fig. 18).

Ulmites microphylla (NEWBERRY) comb. nov.

Text-fig. 10

1868 Planera microphylla NEWBERRY, Lyceum Nat. Hist. New York Ann., 9, p. 55 [basionym]; 1898 Newberry U. S. Geol. Surv. Monogr., 35, p. 81, pl. 33, figs 3, 4.

1977 Chaetoptelea microphylla (NEWBERRY) HiCKEY, Geol. Soc. Amer Mem. 150, p. 122, and synonymy therein.

Brown (1962) distinguished three species of ulmaceous foliage on the basis of shape (e.g., cordate base in Planera microphylla vs cuneate or rounded base in Zelkova planeroides) and size (relatively large in Ulmus rhamnifolia), but it seems likely that these represent variation within one species, given the range of morphology documented in leaves of modern individuals (Denk and Dillhoff 2005). Kvaček et al. (1994) adopted the non-committal name Ulmites DAWSON for Paleogene leaf types that may not unequivocally belong to the genus Ulmus.

Hickey (1977) reassigned Planera microphylla NEwBERRY to Chaetoptelea, a segregate genus of Ulmus that was subsequently demoted to subgeneric status. A twig bearing several leaves of Ulmites microphylla from Black Buttes Coal Mine Pit 3, in southwestern Wyoming shows the distichous attachment of leaves to a twig as expected for Ulmaceae (Text-fig. 10). No fossil fruits of Ulmus (including 


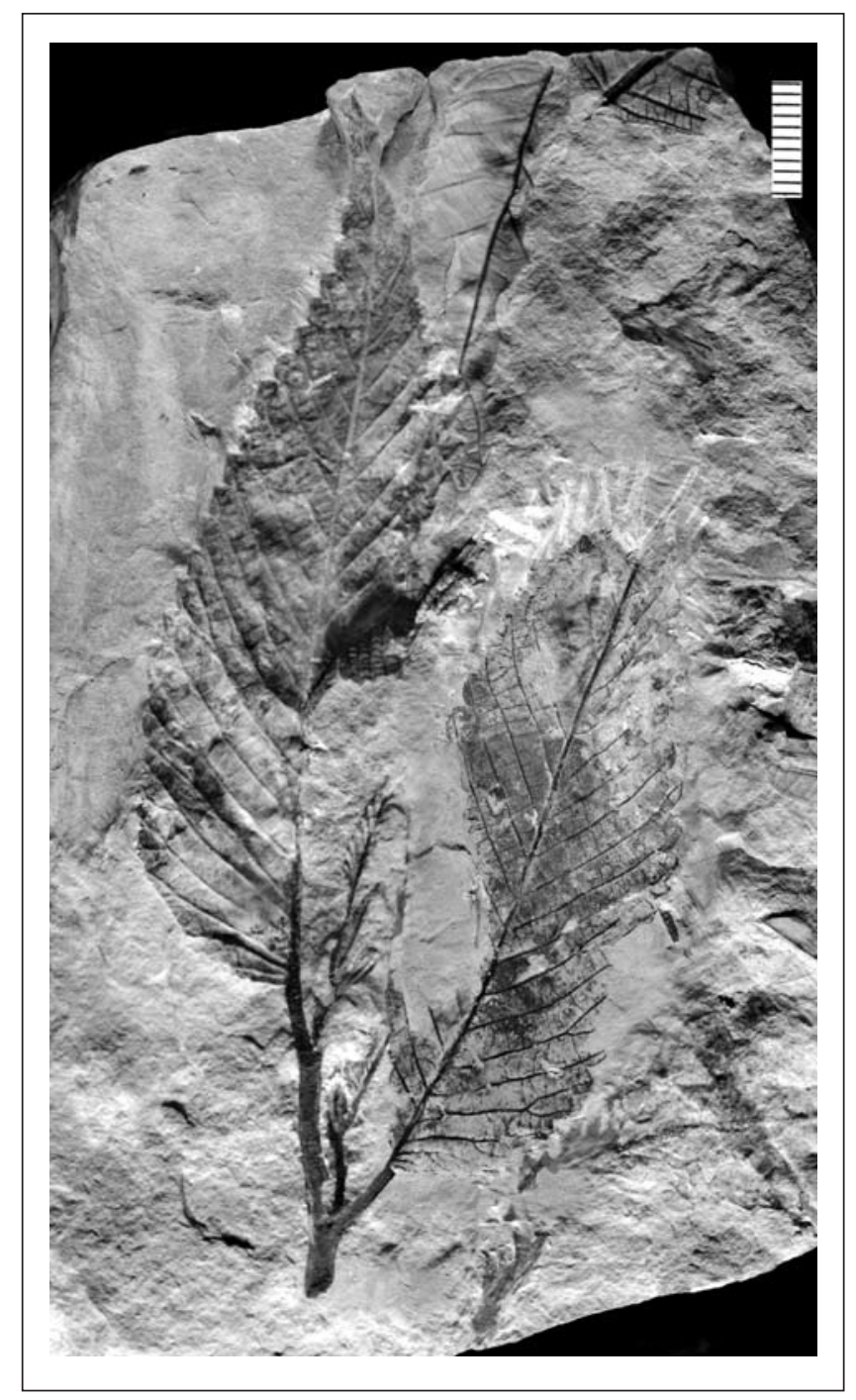

Text-fig. 10. Ulmaceae. Ulmites microphylla (NEWBERRY) comb. nov. Twig with distichously attached leaves, Black Buttes Mine pit 3, Wyoming, UF 15886-14248. Scale bar $=1 \mathrm{~cm}$.

Chaetoptelea morphology) have been recovered from Paleocene strata, although they are relatively common in the Eocene of western North America (Manchester 1989; Denk and Dillhoff 2005). I recommend that these leaves be placed in the genus Ulmites DAwSON and here above establish the new combination Ulmites microphylla (NEWBERRY) comb. nov. In addition to the species placed in synonymy by Hickey (under the name Chaetoptelea microphylla (NEWBERRY) HICKEY), I consider the leaves of U. rhamnifolia and Zelkova planeroides sensu Brown (1962) to be representatives of this species.

In reviewing specimens from the Paleocene of Russia and China they attributed to U. furcinervis, Feng et al. (2003, p. $149)$ observed, "Fossils described here are comparable to $C$. microphylla in the frequently forked secondary veins, the percurrent tertiary and the convex to acuminate apical side and the convex basal side of marginal teeth. We suggest that these fossils are probably conspecific considering their close similarities. Further works should be done to get more evidence and to verify this idea." If indeed conspecific, Newberry's epithet, microphylla, will take priority.

\section{Celtidaceae/Cannabaceae}

Brown (1962) attributed two species to the genus Celtis, i.e., Celtis newberryi KnOwlton et Cockerell, and Celtis peracuminata $\mathrm{R}$. W. BROwN. The first of these has not been disputed, although a more detailed study is warranted. Celtis peracuminata $\mathrm{R}$. W. BROWN appears to be too symmetrical and regularly serrate to be reliably assigned to Celtis. This leaf, recorded only from a single Paleocene site, resembles Grewiopsis wyomingensis BERRY that became common in the middle Eocene.

\section{Celtis aspera (NEWBERRY) MANCHESTER, AKHMETIEV et KODRUL}

Manchester et al. (2002) reassigned leaves of Viburnum asperum NEWBERRY to Celtis aspera based on a suite of foliar features common to Cannabaceae/Celtidaceae such as blunt teeth with submedial vein insertion, abundant, regularly spaced agrophic veins, and noted a consistent association with diagnostic reticulately sculptured endocarps of Celtis at Paleocene sites both in North America and Asia. None of the extant species of Celtis has identical leaf architecture, but the presence of corresponding leaf architecture in one of the extant species of the related genus Aphananthe (Manchester et al. 2002; Stockey et al. 2013), shows the potential for this leaf architectural pattern in the family and supports the conclusion that this foliage type was probably produced by the same plant as the Celtis endocarps. Endocarps of extant Aphananthe species differ from Celtis by having a smooth, rather than reticulate, outer surface. Stockey et al. (2014) disagree with the Celtis interpretation and refer the leaves to Aphananthe sp., although Aphananthe-like fruits are absent and Celtis fruits are present at their localities as at other Paleocene sites in North America and Asia cited by Manchester et al. (2002).

\section{Malvaceae s.l.}

\section{Penosphyllum cordatum (WARD) HICKEY.}

This species was treated by Ward (1887) and Brown (1962) under the name Pterospermites, but that generic name, based on probable winged seeds from the Miocene of Oeningen, had been incorrectly applied to leaves, so Hickey (1977) coined the genus Penosphyllum. The leaves resemble those of some sterculioid Malvaceae.

\section{Sapindaceae}

\section{Aesculus hickeyi MANCHESTER}

\section{Aesculus hickeyi Manchester p. 986, figs 1-4.}

Aesculus hickeyi was common in the Paleocene of Wyoming, Montana, North Dakota, and Alberta. It is known from completely preserved palmately compound leaves as well as abundant shed leaflets, occasional spiny fruit capsule remains, and associated dispersed pollen (Manchester 2001). The leaflets are recognizable by acute bases, short or absent petiolule, and, in this species, a marginal serration consisting of very fine, closely spaced teeth. Tertiary venation is percurrent and weakly impressed. 
Acer sp.

Some of the samaras that were called Acer sp. by Brown (1962, especially pl. 46, figs 9, 10) appear to be genuine examples of that genus, having an oblique proximal scar indicating schizocarpic separation-one of the diagnostic features of Acer. Similar Acer-like samaras were recognized by Crane et al. (1990) from Almont, North Dakota, although corresponding foliage was not recognized.

Acer fragilis KNOWLTON 1917 was transferred to Cissites panduratus KNOWLTON by Wolfe and Tanai (1987).

Acer newberryi R. W. BRown was revised as Dicotylophyllum trilobum (NEWBERRY) by Wolfe and Tanai (1987). "The only criterion on which the foliage just cited has been placed in Acer is a trifoliate condition. The leaflets lack bifurcating secondary veins that brace dental sinuses (as are present in Negundo); the dental sinuses are braced by an apically directed external secondary vein that originates from a secondary vein subjacent to the sinus, a morphology unknown in Acer. Although the tertiary veins are A-A [referring to Hickey's (1973) terminology, i.e., convexpercurrent; forming acute angles with the sub- and superadjacent secondary veins], they are more closely spaced than in Acer and have a "stringy" appearance. No extant family combines such characters." (Wolfe and Tanai 1987, p. 212).

\section{Leguminosae}

Leguminosites coloradensis KNOWLTON. The genus Leguminosites was based on seeds from the London Clay that are not of leguminous affinity (Wang 2012). Instead, this species should perhaps be placed in the genus Leguminocarpum DotzleR. However, Brown (1962, p. 74) expressed uncertainty whether these fruits represent pods of legumes, "or perhaps some other family of plants such as the Bignoniaceae."

"Robinia" wardii (KNOWLTON) WARD. These pods from the Fort Union Formation differ from the type material of Robinia wardii from Eocene of Yellowstone National Park and therefore require a different specific epithet. They are clearly legume fruits, but the generic assignment is in need of revision (Herendeen, pers. comm. 2014).

\section{? Rhamnaceae}

The presence of Rhamnaceae in these floras is not fully proven, but some of the leaves, e.g. Rhamnus cleburnii LESQUEREUX and Zizyphus fibrillosus (LESQUEREUX) LESQUEREUX have distinctive venation that is consistent with some extant Rhamnaceae. "Rhamnus" geowandrewsii WATT (syn. Rhamnus hirsuta R. W. BROWN), does not appear to represent Rhamnaceae and is treated here among insertae sedis.

\section{Rhamnites cleburnii (LESQUEREUX) MCIVER et BASINGER}

Brown (1962) indicated that Rhamnus cleburnii and $R$. goldiana (types both from the same locality) are very similar except that the former has a cuneate base and the latter is cordate. The cordate-based leaves have a series of strong agrophic veins. McIver and Basinger (1993) designated $R$. cleburnii as the type species of the fossil genus, Rhamnites, and established the new combination Rhamnites cleburnii. The closely spaced percurrent tertiaries are consistent with Berchemia, Karwinskia, Rhamnidium, Rhamnus, and some other genera of Rhamnaceae. The leaves are always entire-margined, contrasting with the serrate condition in many extant species of Rhamnus. From the same locality, an entire-margined leaf that Brown (1962, P1. 39, fig. 2) figured as Magnolia regalis HEER, has closely spaced oppositepercurrent tertiary veins unlike Magnolia and appears to represent Rhamnites cleburnii. Leaves with similar architecture including the scalariform type of intercostal venation, occur in Dipterocarpaceae (e.g., Hopea, Parashorea, Shorea), and Dilleniaceae (e.g. Tetracera). Wolfe (1977) attributed leaves from the Paleogene of Alaska, to Dipterocarpaceae, but the distinctive winged fruits of that family have not been recovered from Alaska or any other North American paleobotanical sites.

\section{“Zizyphus” fibrillosus (LESQUEREUX) LESQUEREUX}

This species resembles some Rhamnaceae in 1) the closely spaced percurrent tertiaries, and 2) in the acrodromous pattern with numerous agrophics. However, the first pattern, found in genera like Rhamnus, Karwinskia, Berchemia, is not generally linked with the second pattern in the same genera. When actinodromy occurs, for example in Ziziphus, Colubrina, etc., the tertiary venation is more irregular and not closely spaced percurrent. It therefore seems unlikely that this leaf belongs in an extant genus of the Rhamnaceae, and the assignment to Ziziphus is probably incorrect. The generic name for this species was also placed in quotation marks by Ellis et al. (2003), indicating that that they were not convinced that it represents extant Zizyphus.

\section{Vitaceae}

Brown (1962) confirmed the presence of the grape family by documenting a seed with the characteristic paired ventral infolds, which he assigned to Vitis sp. The dorsal side of the seed is not known. A silicified seed of Ampelocissus was also identified from the Paleocene of North Dakota (Chen and Manchester 2007).

Reports of Vitaceae based on leaves have not been completely convincing. These include Ampelopsis acerifolia (reassigned to Archeampelos acerifolia (NEWBERRY) MCLVER et BAsinger, see Cercidiphyllaceae, above), Cissus marginata and (reassigned to Platanaceae as Platanites marginata), Vitis lobata (KNOWLTON) R. W. BROWN (reassigned to Cucurbitaciphyllum lobatum, above). The leaf identified as Vitis olrikii HeER by Brown (1962) was separated from the Greenland species and given a new binomial, Dicotylophyllum hansonium PEPPE et HickeY (2014). Others that require additional study are Cissites rocklandensis R. W. BROWN, and Parthenocissus ursina R. W. BRown. Cissites rocklandensis has a broadly ovate lamina with three asymmetrically and weakly developed lobes, with a rounded sinus between the middle lobe and each of the lateral lobes. This resembles the leaves of Gyrocarpus (Hernandiaceae) and Exbucklandia (Hamamelidaceae). 


\section{Ericaceae}

\section{“Kalmia” elliptica R. W. BROWN}

This species is represented by elliptic leaves with entire margins, and pinnate secondaries that arise decurrently from the midvein. Hickey (1977) considered the attribution to Ericaceae likely to be correct, based on several apparently unique leaf architectural characters.

\section{Cornales}

The order Cornales was particularly well represented in the Paleocene of the Rocky Mountains and Great Plains region. Examples include Cornus (already recognized by Brown 1962), Davidia, Amersinia/Beringiaphyllum (previously treated as Viburnum), and Browniea (previously treated as Eucommia). At some sites one or more of the latter three genera are dominants of the community. Pollen of Nyssapollenites thompsonianus THIERGART ex POTONIE and Cornus sp. are known from Almont, North Dakota (Zetter et al. 2011).

\section{Cornus swingii MANCHESTER, XIANG, KODRUL et AKHMETIEV}

Brown (1962) recognized two species of dogwoods: Cornus hyperborea HeER, and C. nebrascensis SCHIMPER. However, the holotype of $C$. nebrascensis SCHIMPER (=C. acuminata NEWBERRY and $C$. newberryi HOLLICK) has marginal teeth (Brown 1962; Johnson 2002), unlike any extant Cornus, lacks the distinctive double-armed trichome impressions expected for Cornus (Manchester et al. 2009), and now serves as the basis for a new extinct genus, Mciveraephyllum, established here on p. 178. Additionally, the lectotype of Cornus hyperborea HEER, from the Paleocene of Greenland, might be Cornus, but other affinities, e.g., to Lauraceae, cannot be ruled out because it lacks impressions of the diagnostic compass-needle like trichomes. In order to accommodate leaves from the Paleocene of Wyoming, Montana and North Dakota that could be placed with confidence in Cornus, due to the preservation of their distinctive trichomes, Manchester et al. (2009) established a new binomial, Cornus swingii. The fruits produced by Cornus swingii remain unknown, but anatomically preserved fruits of Cornus subgenus Cornus have been described from the Paleocene of North Dakota (Manchester et al. 2010) as Cornus piggae.

\section{Davidia antiqua (NEWBERRY) MANCHESTER}

Davidia, the dove tree, was particularly common in the Paleocene of Wyoming, Montana, and North Dakota (Manchester 2002). Although the laminae are similar in general form to some extant species of Viburnum and were called Viburnum antiquum (NEwBERry) Hollick sensu Brown (leaves), and the associated detached fruits were called Viburnum tilioides WARD (Brown 1962), the leaves can be distinguished from most Viburnum by their long petioles, and the fruits by the presence of germination valves, five or more radially arranged single-seeded locules and lack of a well-defined axial vascular bundle (Manchester 2002).
Fruits of Davidia antiqua were borne singly on an elliptical inflorescence head, subtended by scars that bore large bracts like those of modern Davidia involucrata of China.

\section{Beringiaphyllum cupanioides (NEWBERRY) MANCHESTER, Crane et Golovneva}

In addition to the modern genera mentioned above, Cornales were well represented by extinct genera. One of these was Amersinia MAnchester, Crane et Golovneva, the fruits of which are known from China and Far Eastern Russia, as well as Wyoming, Montana, North Dakota, and Alberta. Amersinia bore elliptical infructescence heads on long peduncles, bearing numerous trilocular fruits with apical germination valves. The morphology and anatomy of these fruits, preserved in silicified specimens, confirms their position within Nyssaceae having characters shared with extant Davidia and Camptotheca. Consistently associated with Amersinia fruiting material, both in North America and eastern Asia, are leaves of Beringiaphyllum cupanioides Manchester, Crane et Golovneva, which Brown had called Viburnum cupanioides (Manchester et al. 1999; Feng et al. 2002). The Beringiaphyllum-Amersinia plant appears to have been common near sites of lacustrine deposition during the Paleocene.

\section{Browniea serrata (NEWBERRY) MANCHESTER et HICKEY}

Browniea serrata (NEWBERRY) MANCHESTER et HickeY (2007) is a species of an extinct genus related to extant Camptotheca (Nyssaceae) that was common in the Paleocene of Colorado, Wyoming, Montana, and North Dakota. The leaves, formerly called Eucommia serrata (NEWBERRY) BROWN (1962), have pinnate venation with semicraspedodromous secondaries, and regularly serrate margins, and they bear microscopic impressions of probable calcium oxylate idioblasts like the leaves of modern Camptotheca. At many localities, these leaves co-occur with globose multi-fruited infructescences resembling those of Camptotheca. The spindle-shaped fruits, which Brown referred to as "Probably fruits with remnants of calyces" (1962, pl. 67, figs 11, 12, 17) are similar to those of Camptotheca in shape and epigynous calyx, but the calyx is much better developed in the fossil taxon. Flowers with attached stamens yield pollen of Caprifoliipites paleocenicus Pocknall et Nichols (Manchester and Hickey 2007). A specimen illustrated by Brown as "calyx of a flower (pl. 67, fig. 46), matches that of Browniea. Additional specimens were illustrated as Amelanchites similis (NEWBERRY) MCIVER et BAsinger (1993, pl. 29, figs 1-5; pl. 30, fig. 3) from Ravenscrag Butte, Saskatchewan, Canada; Early Paleocene, although the type of that species actually belongs to Celtis aspera (NEWBERRY) MANCHESTER, AKHMETIEV et KODRUL.

\section{Icacinaceae}

Unequivocal fruits of Icacinaceae occur in the North American Paleocene, but corresponding foliage has not yet been identified. The specimen illustrated as "impression of a seed showing pits arranged in longitudinal rows" (Brown 1962, pl. 67, fig. 26), and specimens from other Paleocene localities in Wyoming and Montana, have been assigned to 
the extinct genus Palaeophytocrene, as Palaeophytocrene piggae Stull, and clearly belong to the tribe Phytocreneae (Stull et al. 2012) which is now restricted to the Old World tropics.

Reticulately ridged fruits formerly placed in Prunus corrugis R. W. BROWN were transferred to Icacinicaryites corruga (R. W. Brown) Pigg, MAnchester et DeVore (large fruit-3.8 cm long), and Icacinicaryites linchensis PigG, Manchester et DeVore (smaller fruits-1.5-2.7 cm long). Along with anatomically preserved silicified specimens given different taxonomic assignments these fruits conform to those of the icacinaceous tribe Iodeae (Pigg et al. 2008).

\section{Bignoniaceae}

Seeds of Bignoniaceae. Brown (1962 pl. 68, figs 17-22) illustrated several biwinged seeds from a single locality in SE Montana. These small seeds have a triangular central body, with two elongate strap-like wings arising at $90^{\circ}$ to the vertical seed axis. The wings are membranous, and without veins, and conform well with the pattern of seeds in the Bignoniaceae.

\section{Elaeocarpaceae}

\section{Sloanea ungeri (HEER) MANCHESTER et Z. KVAČEK}

Sloanea ungeri (HeER) MANCHESTER et Z. KVAČEK is based on spiny capsular fruits with long peduncle and hypogynous disk that conform well with the morphology of extant Sloanea (Manchester and Kvaček 2009). It is disconcerting, however, that no obvious leaves of Sloanea have been found in co-occurrence. Leaves of extant Sloanea have prominent thickening and a twist at the junction of lamina with petiole that has not been observed among the leaves associated with these fossil fruits. One of the specimens was referred to as "elliptic fruit with a fringe of hairs or filaments" (Brown 1962, pl. 67, fig. 35).

\section{Polygonaceae}

\section{Paranymphaea crassifolia (NEWBERRY) BERRY}

Leaves of Paranymphaea crassifolia (NEWBERRY) BERRY were studied in detail by McIver and Basinger (1993) who demonstrated that the leaf architecture is very distinct from that of Nymphaea and other Nymphaeaceae and appears instead to be diagnostic of Polygonaceae, e.g., Polygonum and Rheum. This is distinctive leaf type is mostly confined to the lower Paleocene of the Rocky Mountain region.

\section{Polygonocarpum curtisii MANCHESTER et O'LEARY}

A winged fruit of Polygonocarpum curtisii fruit was figured as Ulmus rhamnifolia WARD by Brown (1962, pl. 24, fig. 17) this fruit type was compared informally with Wimmeria by Crane et al. (1990). The fruits are are pedicellate, wide-elliptical with an emarginate base and apex, 9-10 $\mathrm{mm}$ high and $12-14 \mathrm{~mm}$ wide, with three radially arranged longitudinal wings diverging from a central fusiform, single-seeded endocarp. Several longitudinal veins run the full length of the fruit body. The wings are chartaceous, with a dense anastomosing network of fine venation but lacking marginal veins (Manchester and O’Leary 2010).

\section{Podopterus antiqua MANCHESTER et O'LEARY}

A fruit of Podopterus antiqua was previously figured as Ulmus rhamnifolia WARD by Brown (1962, pl. 24, fig. 18). The fruits are obovate, composed of three longitudinal chartaceous wings with an emarginate apex and cuneate base, an elliptical, single-seeded endocarp, and narrow pedicel. The wings have a dense anastomosing network of fine venation but lack a distinct marginal vein. All of these features conform well to those seen in the modern genus Podopterus (Manchester and O’Leary 2010).

\section{Extinct taxa of uncertain affinities}

\section{Averrhoites affinis (NEWBERRY) HICKEY}

Averrhoites affinis was established by Hickey (1977) for the pinnately compound leaves that Brown (1962) called Sapindus affinis (NewBERry) Brown. The leaves bear as many as 11 leaflets that are asymmetrical, ovate to elliptic, and entire-margined with 8 to 13 pairs of secondary veins. Although the familial affinities remain uncertain, it is noteworthy that this foliage type very often co-occurs with flowers of Calycites polysepala NEWBERRY. Scott Wing (pers. comm.) has obtained Pistilipollentites pollen from stamens of these flowers, indicating that they are equivalent to (and have nomenclatural priority) over the genus, Pistillipollianthus that was established on flowers from the Eocene of Horsefly, British Colombia (Stockey and Manchester 1988).

\section{Quereuxia angulata (NEWBERRY) KRYSHTOFOVICH}

A distinctive floating aquatic plant known as Quereuxia angulata (NEWBERry) KRYSHTOFOVICH ranged from the upper Cretaceous through Paleocene of North America and Asia (Stockey and Rothwell 1997; as Trapago angulata). The plant was called Trapa angulata (NEWBERRY) R. W. BROWN (1962) but represents an extinct genus. It was named Trapago by McIver and Basinger (1993) but this is a junior synonym of Quereuxia (see Hickey 2001 for nomenclatural review). The laterally compressed rhizome with attached leaves and roots illustrated as Trapa paulula (BELL) R. W. BROWN (1962) also appears to represent this genus.

\section{Dicotylophyllum silberlingii \\ (R. W. Brown) J. Wolfe et TANAI}

Acer silberlingii R. W. Brown (1962, p. 76. pl. 46, fig. 7) was transferred to Dicotylophyllum silberlingii by Wolfe and Tanai (1987). According to those authors, "The single specimen of "Acer" silberlingii has intercostal venation comprised of many admedially oriented tertiary veins, some camptodromous secondary veins, narrowly arcuate dental sinuses, and veins that enter teeth have strong lateral bracing veins. The specimen is clearly not Acer, but we are unable to suggest a valid familial assignment." (Wolfe and Tanai 1987, p. 211-212). From another upper Paleocene locality, 
however, Scott Wing (pers. comm., 2014), has observed this leaf species in close association with schizocarpic fruits that do indeed represent Acer-leading to the suggestion that the possible affinity of these leaves to Acer needs to be reconsidered.

\section{Porosia verrucosa (LESQUERUEX) HICKEY emend. MANCHESTER et KODRUL}

1878 Carpites verrucosus LESQUEREUX p. 305, Pl. 10, fig. 9 (basionym)

1962 Hydromystria expansa (HEER) HANTKE in Brown 1962 (part); p. 52, Pl. 16, figs 1, 3, 10, only

1977 Porosia verrucosa (LESQUereux) Hickey 1977, p. 114, pl. 54, figs 1, 3, 4 (not 2).

2014 Porosia verrucosa (Lesquereux) Hickey emend MANChester et KodRul 2014 p. 82-83, Pl. 1-5.

Porosia verrucosa is a distinctive fruit type that existed from the Campanian to the Eocene; it was particularly common in the Paleocene of western North America and Far Eastern Russia (Hickey 1977; Manchester and Kodrul 2014). The fruits were borne in schizocarpic pairs on stout pedicels with hypgynous perianth scar and bore numerous prominent circular cavities within the wall of each endocarp. The affinities are still uncertain although general similarities with Rutaceae have been noted (Manchester and Kodrul 2014). Brown (1962) included these remains, along with leaves now treated separately as Limnobiophyllum, in his concept of Hydromystria expansa (HEER) HANTKE. Although considered at that time to be float leaves of an aquatic plant, the internal structure revealed in permineralized specimens, confirms that Porosia were unilocular, single-seeded fruits (Manchester and Kodrul 2014).

\section{Deviacer wolfei MANCHESTER}

Brown (1962, pl. 67, fig. 67, 7) illustrated this fruit type as "maplelike samaras, but probably of sapindaceous affinity." The fruits are not Acer because they are borne singly on the pedicel, lacking the schizocarpic condition and possess a small rudder like protuberance arising from the thickened edge of the wing near the distal edge of the seed body which is not present in Acer. A similar rudder like protuberance occurs in superficially similar fruits of extant Securidaca (MacGinitie 1974; Pigg et al. 2008) but the basal perianth scar seen in dispersed fruits of modern Securidaca has not been observed in any of the fossil specimens. Brown's "maplelike samaras" correspond to the extinct taxon Deviacer wolfei MANCHESTER (1994), known from the Paleogene of western North America, China, and Denmark (pers. obs.). The familial affinities are uncertain to me.

\section{“Koelreuteria” annosa R. W. BROWN}

This name was established by Brown (1956) for an elliptical fin-winged fruit from the vicinity of Jim Bridger coal mine, east of Rock Springs, Wyoming. Later, he included a leaflet, from a different site in Montana, under the same name (Brown 1962). More specimens of the winged fruit have been recovered from sites near the type locality, but detailed study shows that they are not Koelreuteria. The pedicel is extremely thin compared to that of Koelreuteria, and the fruit has bilateral, rather than trifold, symmetry. The specimens also lack the globose seeds typically found in Koelreuteria fruits, and have a fusiform locular area that is narrower than that of Koelreuteria. Despite a survey of fin-winged fruits in more than 140 extant genera in 45 angiosperm families (Manchester and O'Leary 2010), it has not been possible to find a close match for these fruits. "Koelreuteria" annosa is similar to fruits of extant Rutaceae in being indehiscent, and nonschizocarpic, with hypogynous perianth scar, but the venation is not as reticulate as in extant Ptelea, Balfourodendron, and Spathelia (Manchester and O'Leary 2010). The association of this species with the foliage illustrated by Brown (1962) is tenuous, and the identification of that specimen requires reexamination.

\section{Leepierceia preartocarpoides}

(R. W. BROWN) K. JOHNSON

Leepiercea $\mathrm{K}$. JOHNSON is an extinct genus of possible hamamelidalean affinity, known mostly from the Late Cretaceous. One of the Paleocene specimens attributed to Ficus arctocarpoides by Brown (1962, pl. 24, fig. 4) was reassigned to this species by Johnson (1996).

\section{Mciveraephyllum gen. nov.}

D i a $g$ n o s i s . Leaves simple, with elliptical to obovate lamina, apex acute, base acute to cordate. Petiole slender and at least $1 / 4$ as long as the lamina. Lamina entire-margined to (more commonly) serrate, especially in the apical half. Teeth prominent, acute, but not spinose, apparently nonglandular with rounded sinuses. Venation pinnate, eucamptodromous to craspedodromous with 7-9 pairs of uniformaly spaced secondary veins arising at acute angles from the midvein. Intersecondary veins absent. Tertiary veins percurrent, weakly impressed.

Type species. Mciveraephyllum nebrascense (SCHIMPER) comb. nov.

Etymology. Named in memory of paleobotanist, Elisabeth E. McIver (1942 to 2001).

\section{Mciveraephyllum nebrascense (SCHIMPER) comb. nov.}

\section{Text-fig. 11}

1868 Cornus acuminata NewBERRY, Lyceum Nat. Hist. New York Ann., 9, p. 71. [non Webber 1852].

1874 Cornus nebrascensis SCHIMPER, Traité de paléontologie végétale 3 , p. 54 [basionym].

1898 Cornus newberryi Hollick in NewBerry, p. 124, pl. 37, figs 2-4.

1962 Ficus artocarpoides Lesquereux auct non. Brown [part], pl. 28, fig. 1-3, 5-7, not 4.

1993 Cornophyllum newberryi (HoLlick) MCIVER et BASINGER p. 45, pl. 35, figs 2-5, Pl. 36, figs 1-3.

L e c t o t y p e (designated here): USNM 8937 (Text-fig. 11.1; pl. 37, fig. 4 of Newberry 1898).

Emended Diagnos is provided by McIver and Basinger (1993, "Cornophyllum newberryi"

As summarized by Peppe (2009), the diagnostic features of this species are the highly ascending, evenly spaced, 
eucamptodromous secondary veins that turn sharply up near the margin and become increasingly decurrent in their attachment to the mid-vein towards the base, and the tendancy for prominent marginal teeth. This species was initially called Cornus acuminata NEwBERRY (1868) (subsequently renamed twice because the binomial was a junior homonym of Cornus acuminata WeBBER: Cornus nebracensis SCHIMPER 1874 and Cornus newberryi HOLLICK in NEWBERRY 1898) was founded on three syntypes from "Yellowstone River, Montana" [probably in the vicinity of present-day Miles City] ranging from entire-margined to, in the case of the lectotype, having prominent teeth in the upper half of the lamina (text-fig. 11; Brown 1962, Manchester et al. 2009).

Although extant Cornus can have a minutely erose margin (Hickey 1977), no species of this genus have prominent teeth, so the original assignment of this species to Cornus is not supported. One of the diagnostic features of Cornus leaves is the presence of abundant calcified double-armed acicular trichomes. This feature also does not occur in Newberry's species, although the trichomes are preseved and visible as impressions under high magnification in many genuine Cornus leaves from various sites of the Fort Union Formation (Cornus swingii Manchester, Xiang, Kodrul et Akhmetiev 2009). The lectotype, and other architecturally similar specimens, do not show any such trichomes. Although it is clear that Newberry's species does not belong to Cornus, the true systematic affinities remain uncertain. I therefore propose a new genus, Mciveraephyllum, accommodating Mciveraephyllum nebrascense (SCHIMPER) comb. nov. McIver and Basinger (1993) also concluded that this species cannot be Cornus, and reassigned it to the genus Cornophyllum Newberry. However, Cornophyllum was diagnosed on the basis of entire-margined leaves from the Cretaceous Raritan of New Jersey (Newberry 1895), and therefore is not appropriate for this leaf type which commonly is toothed. Because the original binomial, Cornus acuminata, was illegitimate, the epithet with priority is nebrascensis, as explained by Peppe (2009).

Most of the leaves placed by Brown (1962) in Ficus artocarpoides LESQUEREUX belong to Mciveraephyllum nebrascensis [except for one of the figured specimens (Brown 1962, pl. 24, fig. 4) that subsequently transferred to Leepierceia preartocarpoides (R. W. BROWN) K. Johnson (Johnson 1996)]. M. nebrascensis leaves vary from entire margined to dentate, with sharp, widely spaced teeth and rounded sinuses and have moderately long petioles. Leepierceia has laminae with similar teeth, but the base is usually cordate, and the tertiaries and higher order veins are much more prominent (Johnson 1996).

\section{Wardiaphyllum daturaefolium (WARD) HICKEY.}

Brown (1962) attributed this distinctively toothed, long-petiolate leaf type to Credneria? daturaefolia WARD. These leaves are also common in the Paleocene Gao mine flora of Alberta (Stockey et al. 2013). No association with fruits or flowers has been detected.

\section{Remaining species whose generic and familial assignments remain unproven}

Other species included in Brown's monograph that have not been subjected to more detailed study include: Apocynophyllum lesquereuxii Ettingshausen (fragmentary leaves of uncertain affinity), "Asimina” vesperalis R. W. Brown, Calycites hexaphylla LESQUEREUX, "Cercocarpus" ravenscragensis BERRY, Dillenites garfieldensis R. W. Brown, Dombeyopsis magnifica Knowlton, "Fraxinus" eocenica LesquereuX, Hydrangea antica R. W. Brown, Phyllites demoresi R. W. Brown, Phyllites disturbans R. W. Brown, Phyllites pagosensis KnOwLton, Ilex artocarpidioides (LesquereuX) R. W. Brown, Paliurus? sp., Zyzyphoides mackayi BELL, "Staphylea" minutidens (KnOwlton) R. W. Brown, "Salix” aquilina R. W. Brown ("These fragmentary leaves are referred to Salix with some hesitation." Brown 1962, p. 55).

"Ficus" affinis (LeSQuereuX) R. W. Brown. This entiremargined ovate leaf, "hesitatingly assigned to Ficus" by Brown (1962, p. 61) has three primary veins and 3-5 pairs of secondary veins arising from the upper half of the midvein. Particularly strong outer secondary veins arise somewhat above the base of both lateral primaries. The base of the lamina is decurrent on the petiole. Brown expanded the concept of this species to include narrow elliptical leaves based on co-occurrence with the broader ovate specimens on which the species was founded. Identification to the genus Ficus was not justified on the basis of morphological characters. Lesquereux's original assignment to Cinnamomum, or at least the familial attribution to Lauraceae, appears more likely to be correct. However, unique characters to identify this leaf with certainty have not been noted.

"Ficus" minutidens KNOWLTON has a broad ovate serrate lamina. Brown (1962 p. 62) stated that the acceptance of these leaves as Ficus "is made with reservations because they also resemble somewhat the leaves of Hydrangea, Morus, Populus, Tilia, and some Vitis."

"Ficus" planicostata LesquereuX. These leaves are wide-ovate to elliptical with basally acrodromous venation consisting of a midvein and two strongly ascending lateral primaries. Agrophic veins are common in the lower half of the lamina, and well-marked percurrent tertiary veins are common. The petiole is stout, suggesting an evergreen leaf. Leaves of this species resemble those of some Lauraceae.

"Ficus" subtruncata LESQUEREUX has entire-margined elliptical leaves. "The assignment of these leaves to Ficus is unsatisfactory, but I have no better suggestion" (Brown 1962, p. 63).

"Ficus" uncata Lesquereux. "These leaves resemble some species of Combretum and Magnolia, and their present allocation is dubious." (Brown 1962, p. 64).

"Morus" montanensis R. W. BROwN. This is an ovate leaf with a cordate base, attenuate apex and numerous small crenations. The crenations cover the lower and middle part of the lamina, but are missing from the apical area. Brown noted he had not found any lobed leaves like those from the living species of Morus.

"Nyssa" alata (WARD) R. W. BROWN. Brown provided a synoymy for this species including 17 previously recorded occurrences. These are elliptical entire-margined leaves with 


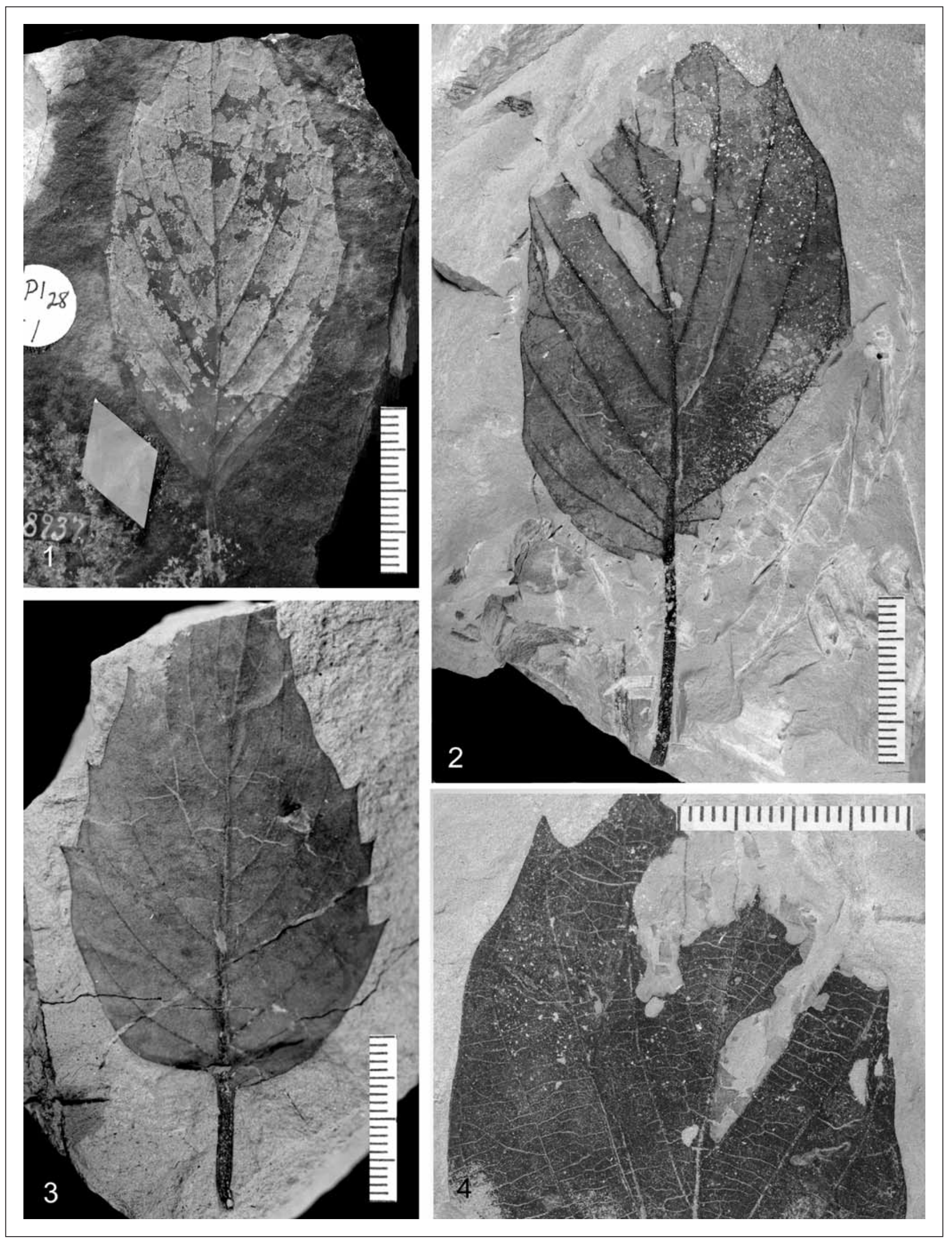

Text-fig. 11. Indet. family. Mciveraephyllum nebrascense (SCHIMPER) comb. nov. 1. Lectotype of Cornus acuminata NEWBERRY 1868 [non Webber 1852] = Cornus nebrascensis SCHIMPER 1874, p. 54, originally pl. 37, fig. 4 in Newberry 1898. Yellowstone River, Montana, USNM 8937. 2. Specimen from Black Buttes pit 3, Wyoming showing moderately long petiole and rounded tooth sinus. UF 15886-14308. 3. Specimen with more abundant teeth, Ludlow Formation, locality DMNH 563, Slope County, North Dakota, Collection of K. Johnson, DMNH 2206. 4. Detail of tertiary venation, counterpart specimen of that figured in 2 . Scale bar $=2 \mathrm{~cm}$. 
pinnate secondary veins - a common leaf architectural pattern not confined to Nyssa. As Brown stated then, "The assignment of these leaves to Nyssa is unconfirmed by any authentic seeds suggestive of the genus." (Brown 1962, p. 85).

"Nyssa" borealis R. W. BROWN. This entire-margined leaf type, with secondaries arising at obtuse angles from the midvein, was named as a new species by Brown (1962). The base and apex are not preserved in the specimen figured.

"Nyssa?" obovata KnOwLTON. "No further light on the identity of this specimen has appeared" Brown (1962, p. 85).

"Rhamnus" geowandrewsii WATT. Rhamnus hirsuta R. W. BROWN is a junior homomym of an extant species, so Watt, (1975) provided a new name, Rhamnus geowandrewsii WATT, for the species. Brown (1962, p. 77) stated "there is some doubt that these leaves represent Rhamnus". Among those that he figured, all from the Shirley Canal site, Montana, there appears to be more than one taxon. Watt (1975) designated, fig. 3, of Brown (1962, pl. 39) as the lectotype which shows a lanceolate, entire-margined lamina with prominent percurrent tertiary veins. Some of the other figures appear to represent the same taxon showing development of scattered teeth. But figs 9, 10 of Brown (1962, pl. 39) with sharp prominent teeth, seem to represent two other unrelated taxa. No justification was been given for placing these leaves in Rhamnaceae. When present, teeth of Rhamnaceae should be blunt and glandular. The familial and generic affinity of "Rhamnus" geowandrewsii remains unknown.

\section{Miscellaneous fruits/seeds}

Although Brown's chief emphasis was on fossil leaves, he collected and analyzed reproductive structures as well. He provisionally retained several species of palms from earlier literature: Palmocarpon commune LesQuereux, Palmocarpon compositum LESQUEREUX, Palmocarpon lineatum LeSQuereuX, Palmocarpon subcylindricum LesquereuX, and Palmocarpon truncatum LESQUEREUX as components of the Paleocene flora but expressed some doubt as to whether they really represent palms (Brown 1962). I have not reexamined the specimens. Brown (1962) also devoted two plates near the end of his monograph to images of various reproductive structures, mostly unidentified, and labeled with some characteristic features, such as "flattened, carbonized fruit with scars," "spike or catkin of seeds," "oval fruit with several locules" etc. The affinities of some of these are now known as indicated in Table 2 (numbers 169-192).

\section{Acknowledgments}

I appreciate encouragement for this work provided by Peter Crane, Kathleen Pigg, Peter Wilf, Scott Wing, and Kirk Johnson. Scott Wing and Jon Wingerath provided access to specimens stored at the Smithsonian Natural History Museum, Hongshan Wang facilitated curation of the specimens studied at UF, James Basinger provided access to collections at University of Saskatchewan, Ruth Stockey to collections at the University of Alberta, and Kirk Johnson and Ian Miller to collections of the Denver Museum of Nature and Science. Elinor Crane and Terry Lott assisted with compilation of species lists for each locality. Terry Lott painstakingly researched and compiled locality coordinates. Zlatko Kvaček, Josef Bogner and Zdeněk Pouzar kindly helped with Latin etymology. I thank Peter Crane, Lena Golovneva, Kirk Johnson, Terry Lott, Jiří Kvaček, Daniel Peppe, Kathleen Pigg, Vasilis Teodoridis, and Scott Wing for advice and helpful edits to the manuscript. This work was supported in part by grants from the National Science Foundation: EAR 9220079, 1338285; INT 74295; BSR 0743474.

\section{References}

APG III (2009): An update of the Angiosperm Phylogeny Group classification for the orders and families of flowering plants. - Bot J. Linnean Soc. 161(2), 105-121. http://dx.doi.org/10.1111/j.1095-8339.2009.00996.x

Arnold, C. A., Lowther, J. S. (1955): A new Cretaceous conifer from northern Alaska. - Am. J. Bot., 42: 522-528. http://dx.doi.org/10.2307/2438688

Ball, M. W., Stebinger, E. (1910): The eastern part of the Little Snake River Coal Field, Wyoming. - U. S. Geol. Surv. Bull., 471: 186-213.

Belt, E. S., Hartman, J. H., Diemer, J. A., Kroeger, T. J., Tibert, N. E., \& Curran, H. A. (2004): Unconformities and age relationships, Tongue River and older members of the Fort Union Formation (Paleocene), western Williston Basin, USA. - Rocky Mountain Geol., 39(2): 113-140. http://dx.doi.org/10.2113/39.2.113

Barclay, R. S., Johnson, K. R., Betterton, W. J., Dilcher, D. L. (2003): Stratigraphy and megaflora of a K-T boundary section in the eastern Denver Basin, Colorado. - Rocky Mt. Geol., 38(1): 45-71. http://dx.doi.org/10.2113/gsrocky.38.1.45

Barnett, V. H. (1914): The Douglas oil and gas field, Converse County, Wyoming. - U. S. Geol. Surv. Bull., 541: 49-88.

Barthel, M. (1976): Eozäne Floren des Geiseltales: Farne und Cycadeen. Abhandlungen des Zentralen Geologischen Institutes. - Paläontol. Abhand., 26: 439-498.

Bauer, C. M., Herald, F. A. (1921): Lignite in the western part of the Fort Berthold Indian Reservation south of Missouri River, North Dakota. - U. S. Geol. Surv. Bull., 726: 109-172.

Beekly, A. L. (1915): Geology and coal resources of North Park, Colorado. - U. S. Geol. Surv. Bull., 596: 1-121.

Benedict, J. C., Pigg, K. B., DeVore, M. L. (2008): Hamawilsonia boglei gen. et sp. nov. (Hamamelidaceae) from the late Paleocene Almont flora of central North Dakota. - Int. J. Plant Sci., 169(5): 687-700. http://dx.doi.org/10.1086/533607

Berry, E. W. (1930): Fossil plants from the Cypress Hills of Alberta and Saskatchewan. - Bull. Nat. Mus. Canada. 63: $15-28$.

Bowen, C. F. (1912): The Baker lignite field, Custer County, Montana. - U. S. Geol. Surv. Bull., 340: 202-226.

Bowen, C. F. (1914): The Big Sandy Coal Field, Chouteau County, Montana. - U. S. Geol. Surv. Bull., 541: 356-378.

Brant, R. A. (1953): Lignite resources of North Dakota. USGS Circular, 226: 1-78.

Brown, R. W. (1939a): Some American fossil plants belonging to the Isoetales. - J. Washington Acad. Sci., 29: 261-269. 
Brown, R. W. (1939b): Fossil leaves, fruits, and seeds of Cercidiphyllum. - J. Paleont., 13(5): 485-499.

Brown, R. W. (1962): Paleocene flora of the Rocky Mountains and Great Plains. - U. S. Geol. Surv. Prof. Pap., 375: 1-119.

Bryson, R. P. (1952): The Coalwood Coal Field Powder River County, Montana. - U. S. Geol. Surv. Bull., 973-B: 23-106.

Budantsev, L. Y., Golovneva, L. B. (2009): Fossil Flora of Arctic II - Palaeogene Flora of Spitsbergen. Russian Academy of Sciences, Komarov Botanical Institute. Marafon, Saint Petersburg, 400 pp.

Catlett, S. R. (2007): Farmlands, Forts, and Country Life. The Story of Southwest Denver. Big Earth Publishing, Boulder, $240 \mathrm{pp}$.

Chaney, W. W., Sanborn, E. I. 1933. The Goshen flora of west Central Oregon. - Carnegie Inst Wash Pub. 439: 1-1-3

Chen, I., Manchester, S. R. (2007): Seed morphology of modern and fossil Ampelocissus (Vitaceae) and implications for phytogeography. - Am. J. Bot., 94: 1534-1553. http://dx.doi.org/10.3732/ajb.94.9.1534

Collier, A. J. (1919): Geology of Northeastern Montana. In: White, D. (ed.), Shorter Contributions to General Geology. - U. S. Geol. Surv. Prof. Paper, 120: 17-39.

Collier, A. J. (1925): The Scobey Lignite Field, Valley, Daniels, and Sheridan Counties, Montana. - U. S. Geol. Surv. Bull., 751: 157-230.

Collier, A. J., Smith, C. D. (1908): The Miles City Coal Field, Montana. - U. S. Geol. Surv. Bull., 341: 36-61.

Collier, A. J., Knechtel, M. M. (1939): The coal resources of McCone County, Montana. - U. S. Geol. Surv. Bull., 905: $1-77$.

Collinson, M. E. (2001): Cainozoic ferns and their distribution. - Brittonia, 53(2): 173-235. http://dx.doi.org/10.1007/BF02812700

Crane, P. R. (1984): A re-evaluation of Cercidiphyllum-like plant fossils from the British early Tertiary. - Bot. J. Linn. Soc., 89: 199-230. http://dx.doi.org/10.1111/j.1095-8339.1984.tb02196.x

Crane, P. R. (1989): Early fossil history and evolution of the Betulaceae. - in Crane, P.R. and Blackmore, S. [eds.], Evolution, Systematics, and fossil history of the Hamamelidae, Volume 2: 'Higher' Hamamelidae, Syst. Assoc. Spec. Vol. 40B: 87-116, Clarendon Press, Oxford, England.

Crane, P. R., Manchester, S. R., Dilcher, D. L. (1988): Morphology and Phylogenetic significance of the angiosperm Platanites hebridicus from the Palaeocene of Scotland. - Palaeontology, 31: 503-517.

Crane, P. R., Stockey, R. A. (1985): Growth and reproductive biology of Joffrea speirsii gen. et. sp. nov., a Cercidiphyllum-like plant from the Late Paleocene of Alberta, Canada. - Canad. J. Bot., 63: 340-364. http://dx.doi.org/10.1139/b85-041

Crane, P. R., Manchester, S. R., Dilcher, D. L. (1990): A preliminary survey of fossil leaves and well-preserved reproductive structures from the Sentinel Butte Formation (Paleocene) near Almont, North Dakota. - Fieldiana Geol., 1418: 1-63.

Crane, P. R., Manchester, S. R., Dilcher, D. L. (1991): Reproductive and vegetative structure of Nordenskioldia
(Trochodendraceae), a vesselless dicotyledon from the Early Tertiary of the Northern Hemisphere. - Am. J. Bot., 78: 1311-1334.

http://dx.doi.org/10.2307/2445271

Crane, P. R., and Stockey, R. A. (1986): Morphology and development of pistillate inflorescences in extant and fossil Cercidiphyllaceae. - Ann. Missouri Bot. Gard., 73: 382-393.

http://dx.doi.org/10.2307/2399118

Crane P. R., Stockey, R. A. (1987): Betula leaves and reproductive structures from the Middle Eocene of British Columbia. - Can. J. Bot., 65: 2490-2500. http://dx.doi.org/10.1139/b87-338

Davis, J. A. (1912): The Little Powder River Coal Field, Campbell County, Wyoming. - U. S. Geol. Surv. Bull., 796: 1-64.

Denk, T. Dillhoff, R.M. (2005): Ulmus leaves and fruits from the Early-Middle Eocene of northwestern North America: Systematics and implications for character evolution within Ulmaceae. - Can. J. Bot., 83: 1663-1681.

Dobbin, C. E. (1930): The Forsyth Coal Field, Rosebud, Treasure, and Big Horn Counties, Montana. - U. S. Geol. Surv. Bull., 812: 1-55.

Dobbins, C. E., Barnett, V. H. (1928): The Gillette Coal Field, Northeastern Wyoming. - U. S. Geol. Surv. Bull. 796A: $1-50$.

Douglas, E. (1908-1909a): Vertebrate fossils from the Fort Union Formation. - Ann. Carnegie Mus., 5: 11-26.

Douglas, E. (1908-1909b). A Geological Reconnaissance in North Dakota, Montana, and Idaho, with Notes on Mesozoic and Cenozoic. - Ann. Carnegie Mus., 5: 211-288.

Earthpoint, accessed 2014. http://www.earthpoint.us/TownshipsSearchByDescriptio n.aspx

Eldridge, G. H. (1896): Economic Coal. Geology of the Denver Basin in Colorado. - U. S. Geol. Surv. Monogr., 27: $317-465$.

Ellis, B., Johnson, K. R., Dunn, R. E. (2003): Evidence for an in situ early Paleocene rainforest from Castle Rock, Colorado. - Rocky Mt. Geol., 38(1): 73-100. http://dx.doi.org/10.2113/gsrocky.38.1.173

Emmons, S. F., Cross, W., Eldridge, G. H. (1896): Geology of the Denver Basin in Colorado. - U. S. Geol. Surv. Monogr., 27: 1-278.

Endo, S. (1968): The flora from the Eocene Woodwardia Formation, Ishikari Coalfield, Hokkaido, Japan. - Bull. Natl. Sci. Mus. Tokyo, 11: 411-449.

Erdei, B, Manchester, S. R., Kvaček, Z. (2012): Dioonopsis HorIUCHI et KIMURA leaves from the Eocene of western North America: a cycad shared with the Paleogene of Japan. - Int. J. Plant Sci., 173(1): 81-95. http://dx.doi.org/10.1086/662654

Fedotov, V. V. (1970): New species of aspidiaceous and polypodiaceous ferns with sporangia from the Paleogene of the Zeya-Bureya depression. - Palaeontol. J., 4: 539-546.

Feng, G. P., Ablaev, A. G., Wang, Y. F., Li, C. S. (2002): Paleocene Wuyun flora in northeast China: Amersinia and Beringiaphyllum of Cornaceae. - Acta Bot. Sinica, 44(4): 481-487. 
Feng, G. P., Ablaev, A. G., Wang, Y. F., Li, C. S. (2003): Paleocene Wuyun flora in Northeast China: Ulmus furcinervis of Ulmaceae. - Acta Bot. Sinica, 45(2): 146151.

Feng, G. P., Li, C. S., Zhilin, S.G., Wang, Y. F., Gabrielyan, I. (2000): Nyssidium jiayinense sp. nov. (Cercidiphyllaceae) of the Early Tertiary flora from north-east China. - Bot. J. Linn. Soc. 134: 17I-181. http://dx.doi.org/10.1111/j.1095-8339.2000.tb00544.x

Freeman, W. B., Mathers, J. G. (1911): Surface water supply of the United States. 1910. Part VII. Lower Mississippi Basin. - U. S. Geol. Surv. Water-Supply Paper, 287: $1-264$

Gardner, J. H. (1909): The coal field between Durango, Colorado, and Monero, New Mexico. - U. S. Geol. Surv. Bull., 341: 352-36.

Gemmill, C. E. C., Johnson, K. R. (1997): Paleoecology of a late Paleocene (Tiffanian) megaflora from the northern Great Divide Basin, Wyoming. - Palaios, 12: 439-448. http://dx.doi.org/10.2307/3515382

GEOLocate. Accessed 2014. Tulane University. www.museum.tulane.edu/geolocate

Gingerich, P. D., Rose, K. D., Krause, D. W. (2006): Early Cenozoic Mammalian Faunas of the Clark's Fork Basin-Polecat Bench Area, Northwestern Wyoming. Pap. Paleont., 24: 51-68.

Goldman, M. I. (1910): The Colorado Springs Coal Field, Colorado. Contributions to Economic Geology 1908, Part II,-Mineral fuels. - U. S. Geol. Surv. Bull., 381: 317-340.

Golovneva, L. B. (1988): A new genus Micoconium (Cupressaceae) from the Late Cretaceous deposits of the north-east of the USSR. - Bot. Zhurn., 73: 1179-1183 (in Russian).

Golovneva, L. B. (1997): Morphology, Systematics and distribution of the genus Haemanthophyllum in the Paleogene floras of the Northern Hemisphere. - Paleont. J., 31(2): 197-207. (Orig. Paleont. Zhurn., 31(2): 77-87.)

Golovneva, L. B. (2000): Early Palaeogene floras of Spitsbergen and North Atlantic floristic exchange. - Acta Univ. Carol. Geol., 44(1): 39-50.

Golovneva, L. B. (2002): Palaeocarpinus (Betulaceae) from the Paleogene of Spitsbergen and Transatlantic floristic migrations. - Paleont. J., 36(4): 422-428. (Orig. Paleont. Zhurn., 31(4): 97-103.)

Golovneva, L. B. (2010): Variation in Epidermal Characters of Ginkgo tzagajanica Samylina (Ginkgoales) from the Paleocene of the Tsagayan Formation (Amur Region) and the taxonomy of Tertiary species of Ginkgo. - Paleont. J. 44 (5): 584-594.

http://dx.doi.org/10.1134/S003103011005014X

GoogleEarth. Accessed 2014. www.google.com/earth

Guo, S.X., Sun, Z., Li, H., Dou, Y. (1984): Palaeocene flora from Altai in Xinjiang, Northwest China. - Bull. Nanjing Inst. Geol. Palaeont., Academia Sinica, 8: 119-146 (in Chinese with English summary).

Guo, S.-X., Kvaček, Z., Manchester, S. R., Zhou, Z.-K. (2012): Ditaxocladus (extinct Cupressaceae, Cupressoideae) from the Upper Cretaceous and Paleocene of the Northern Hemisphere. - Palaeontogr., Abt. B: Palaeobot. Palaeophytol. 288(5-6): 135-159.
Hail, W.J., Leopold E.B. (1960): Paleocene and Eocene age of the Coalmont Formation, North Park, Colorado. US Geol. Surv. Prof. Pap. 400: 260-261.

Hantke, R. (1954): Die fossile Flora der obermiozänen Oehninger-Fundstelle Schrotzburg (Schienerberg, SüdBaden). - Denkschr. Schweiz. Naturforsch. Gesellsch., 80(3): 1-118.

Hares, C. J. (1928): Geology and lignite resources of the Marmarth Field, southwestern North Dakota. - U. S. Geol. Surv. Bull., 775: 1-110.

Hayden, F. V. (1869): Preliminary field report of the U.S. Geol. Survey of Colorado and New Mexico. - US. Geological Survey, Washington, $35 \mathrm{pp}$.

Hayden, F. V. (1885): Report of Dr. F. V. Hayden. - In: Powell, J.W. (ed), Fufth Annual Report of the United States Geological Survey 1883-84, pp. 28-30, U.S. Geol. Survey, Washington,

Heer, O. (1869): Contributions to the fossil flora of North Greenland, being a description of the plants collected by Mr. Edward Whymper during the summer of 1867. - Phil. Trans. Royal Soc. London 159: 445-488. http://dx.doi.org/10.1098/rstl.1869.0016

Heer, O. (1871): Die miocene Flora und Fauna Spitzbergens. - Flora Fossilis Arctica, Band 2, Heft 3: Kgl. Svenska vetenskapsakad. handlingar, 8 (7): 1-98.

Herald, F. A. (1912): The Terry Lignite Field, Custer County, Montana. - U. S. Geol. Surv. Bull., 471: 227-270.

Herald, F. A. (1913): The Williston Lignite Field, Williams County, North Dakota. - U. S. Geol. Surv. Bull., 531-E: 91-157.

Herendeen, P. S., Les, D. H., Dilcher, D. L. (1990): Ceratophyllum (Ceratophyllaceae) from the Tertiary of North America. - Am. J. Bot. 77: 7-16.

Herrera, F., Manchester, S. R., Hoot, S. B., Wefferling, K. M., Carvalho, M. R., Jaramillo, C. (2011): Phytogeographic implications of fossil endocarps of Menispermaceae from the Paleocene of Colombia. - Am. J. Bot., 98(12): 1-14. http://dx.doi.org/10.3732/ajb.1000461

Hettinger, R. D., Honey, J. G., Ellis, M. S., Barclay C. S. V., East, J. A. (2008): Geologic map of Upper Cretaceous and Tertiary strata and coal stratigraphy of the Paleocene Fort Union Formation, Rawlins-Little Snake River area, South-Central Wyoming. U. S. Geol. Surv., Denver.

Hewett, D. F. (1914): The Shoshone River section, Wyoming. - U. S. Geol. Surv. Bull., 541: 89-113.

Hewett, D. F. (1926): Geology and oil and coal resources of the Oregon Basin, Meeteetse, and Grass Creek Basin quadrangles. - U. S. Geol. Surv. Prof. Paper, 145: 1-10.

Hewett, D. F., Lupton, C. T. (1917): Anticlines in the southern part of the Big Horn Basin. - U. S. Geol. Surv. Bull., 656: 1-192.

Hickey, L. J. (1973): Classification of the architecture of dicotyledonous leaves. Am. - J. Bot., 60(1): 17-33.

Hickey, L. J. (1977): Stratigraphy and paleobotany of the Golden Valley Formation (Early Tertiary) of western North Dakota. - Geol. Soc. Am. Memoir., 150: 1-183.

Hickey, L. J. (1980): Paleocene stratigraphy and flora of the Clark's Fork Basin. Early Cenozoic paleontology and stratigraphy of the Bighorn basin, Wyoming. - Univ. Michigan Papers Paleont., 24: 33-49. 
Hickey, L. J. (2001): On the nomenclatural status of the morphogenera, Quereuxia and Trapago. - Taxon, 50: 1119-1124. http://dx.doi.org/10.2307/1224729

Hickey, L. J, Peterson, T. R. K. (1978): Zingiberopsis, a fossil genus of the ginger family from Late Cretaceous to early Eocene sediments of Western Interior North America. Can. J. Bot., 56: 1136-1152. http://dx.doi.org/10.1139/b78-128

Hicks, J. E., Johnson K. R., Obradovich, J. D., Miggins, D. P. (2003): Magnetostratigraphy of Upper Cretaceous (Maastrichtian) to lower Eocene strata of the Denver Basin, Colorado. - Rocky Mountain Geol. 38 (1): 1-27. http://dx.doi.org/10.2113/gsrocky.38.1.1

Historic MapWorks. Accessed 2014. www.historicmapworks.com

Hoffman, G. L., Stockey, R. A. (1999): Geological setting and paleobotany of the Joffre Bridge Roadcut fossil locality (Late Paleocene), Red Deer Valley, Alberta. Can. J. Earth Sci., 36(12): 2073-2084.

Jähnichen, H. (1990): New records of the conifer Amentotaxus gladifolia (Ludgwig) Ferguson, Jähnichen and Alvin, 1978, from the Plish and Czechoslovakian Tertiary and its recognition in Canada, North America and Europe. - Tertiary Res., 12: 69-80.

Johnson, K. (1996): Description of seven common fossil leaf species from the Hell Creek Formation. - Proc. Denver Mus. Nat. Hist. Series 3, 12: 1-47.

Johnson, K. (2002): Megaflora of the Hell Creek and lower Fort Union Formations in the western Dakotas: Vegetational response to climate change, the CretaceousTertiary boundary event, and rapid marine transgression. In: Hartman, J, Johnson, K., Nichols, D. (eds.): The Hell Creek Formation and the Cretaceous-Tertiary boundary in the northern Great Plains: An integrated continental record of the end of the Cretaceous. - Geol. Soc. Am. Spec. Pap., 361: 329-391.

Johnson, K., Reynolds, M. L., Werth, K. W., and Thomasson, J. R. (2003): Overview of the Late Cretaceous, early Paleocene, and early Eocene megafloras of the Denver Basin, Colorado.

Johnson, R. B. (1958): Geology and coal resources of the Walsenburg area, Huerfano County, Colorado. - U. S. Geol. Surv. Bull., 1042-O: 557-583.

Johnson, R. B., Stephens, J. G. (1955): Geologic map of the Walsenburg Area, Huerfano County, Colorado. U. S. Geol. Surv. Oil and Gas Investigations Map OM-161.

Kauffman, E. G., Upchurch Jr, G. R., Nichols, D. J. (1990): The Cretaceous-Tertiary boundary interval at South Table mountain, near Golden, Colorado. - In: anonym (ed): Extinction events in earth history, Lecture notes 30: 365-392.

Knowlton, F. H. (1896): Paleontology. Section I. The fossil plants of the Denver Basin. - US Geol. Surv. Monogr., 27: 466-473.

Knowlton, F. H. (1902): Report on a small collection of fossil plants from the vicinity of Porcupine Butte, Montana. Bull. Torrey Bot. Club, 29(12): 705-709. http://dx.doi.org/10.2307/2478699

Knowlton, F. H. (1907): Field Notes \#6, unpublished (FK-06-June13, 1907-Aug. 28, 1907.pdf).
Knowlton, F. H. (1908): Field Notes \#8, unpublished (FK-08-July10, 1908 to Aug. 25, 1908.pdf).

Knowlton, F. H. (1910): Descriptions of fossil plants from the Mesozoic and Cenozoic of North America. Smithsonian Misc. Coll. 52, 4: 489-496.

Knowlton, F. H. (1917): Fossil floras of the Vermejo and Raton formations of Colorado and New Mexico. - U. S. Geol. Surv. Prof. Paper, 101: 223-435.

Knowlton, F.H. (1919): A catalogue of the Mesozoic and Cenozoic plants of North America. - U. S. Geol. Surv. Bull., 696: 1-815.

Knowlton, F. H. (1922): The Laramie flora of the Denver Basin; with a review of the Laramie problem. - U. S. Geol. Surv. Prof. Paper, 130: 1-175.

Knowlton, F. H. (1924): Flora of the Animas Formation: U. S. Geol. Surv. Prof. Paper, 134: 71-117.

Knowlton, F. H. (1930): The flora of the Denver and associated formations of Colorado: - U. S. Geol. Surv. Prof. Paper, 155: 1-142.

Krassilov, V. (1973): Cuticular structure of Cretaceous angiosperms from the Far East of the USSR. Palaeontographica, B, 142: 105-116.

Krassilov, V. (1976): Tsagayanskaya flora Amurskoy oblasti. Nauka, Moskva (in Russian).

Kvaček, Z., Manchester, S.R. (1999): Eostangeria Barthel (extinct Cycadales) from the Paleogene of western North America and Europe. - Int. J. Plant Sci., 160: 621-629. http://dx.doi.org/10.1086/314152

Kvaček, Z., Manum, S.B. (1993): Ferns in the Spitsbergen Palaeogene. - Palaeontographica Abt. B 230: 169-181.

Kvaček, Z., Manchester, S. R., Guo, S.-X. (2001): Trifoliolate leaves of Platanus bella (Heer) comb. n. from the Paleocene of North America, Greenland, and Asia and their relationships among extinct and extant Platanaceae. Int. J. Plant Sci., 162: 441-458. http://dx.doi.org/10.1086/319574

Kvaček, Z., Manum, S.B., Boulter, M.C. 1994. Angiosperms from the Palaeogene of Spitsbergen, including an unfinished work by A.G. Nathorst. Palaeontographica, B, 232: 103-128.

LeConte, J. L. (1868): Notes on the geology of the survey for the extension of the Union Pacific railway from Smoky Hill, Kansas, to the Rio Grande, Philadelphia. 76 pp.

Lee, W. T. (1917): Geology of the Raton Mesa and other regions in Colorado and New Mexico. - U. S. Geol. Surv. Prof. Paper, 101: 9-221.

LePage, B. A. (2007): The taxonomy and biogeographic history of Glyptostrobus Endlicher (Cupressaceae). Bull. Peabody Mus. Nat. Hist., 48(2): 359-426.

Leonard, A. G. (1906): Field Notes. Courtesy of Curt Hanson, Chester Fritz Library, University of North Dakota, January 2014.

Leonard, A. G. (1908): The geology of southwestern North Dakota with special reference to coal. State Geological Survey of North Dakota Fifth Biennial Report, pp. 27-114.

Lesquereux, L. (1872): Sixth Annual Report of the U.S. Geol. Survey of the Territories. 329 pgs.

Lesquereux, L. (1878): Contributions to the flora of the Western Territories II. The Tertiary flora. - Rept. U. S. Geol. Surv. Terr., 7: 1-366. 
Lesquereux, L. (1883): Contributions to the flora of the Western Territories III. The Cretaceous and Tertiary floras. - Rept. U. S. Geol. Surv. Terr., 8: 1-283.

Lloyd, E. R. (1914): The Cannonball River Lignite Field, Morton, Adams, and Hettinger Counties, North Dakota. - U. S. Geol. Surv. Bull., 541: 243-291.

Lord, N. W. (1913): Analyses of coals in the United States with descriptions of mine and field samples collected between July 1, 1904 and June 30, 1910. - Dep. Interior, Bur. Mines Bull., 22: 1-1200.

Lupton, C. T. (1909): The eastern part of the Bull Mountain Coal Field, Montana. - U. S. Geol. Surv. Bull., 481: 163-189.

MacGinitie, H. D. (1974): An early Middle Eocene flora from the Yellowstone-Absaroka Volcanic Province, northwestern Wind River Basin, Wyoming. - Univ. Calif. Pub. Geol. Sci., 108: 1-103.

Manchester, S.R. (1981): Fossil plants of the Eocene Clarno Nut Beds. - Oregon Geol., 43: 75-81.

Manchester, S. R. (1986): Vegetative and reproductive morphology of an extinct plane tree (Platanaceae) from the Eocene of western North America. - Bot. Gaz., 147: 200-226.

Manchester, S. R. (1987): The fossil history of the Juglandaceae. - Missouri Bot. Gard. Monogr., 21: 1-137.

Manchester, S. R. (1989): Systematics and fossil history of the Ulmaceae - In Crane, P. R., Blackmore, S. (eds), Evolution, Systematics, and fossil history of the Hamamelidae, Volume 2: 'Higher' Hamamelidae, Systematics Association Special Volume no. 40B, pp. 221-252, Clarendon Press, Oxford.

Manchester, S. R. (1994): Fruits and seeds of the Middle Eocene Nut Beds flora, Clarno Formation, north central Oregon. Palaeontogr. - Am., 58: 1-205.

Manchester, S. R. (1999): Biogeographical relationships of North American Tertiary floras. - Annals Missouri Bot. Gard., 86: 472-522. http://dx.doi.org/10.2307/2666183

Manchester, S. R. (2001): Leaves and fruits of Aesculus (Sapindales) from the Paleocene of North America. - Int. J. Plant Sci., 162(4): 985-998. http://dx.doi.org/10.1086/320783

Manchester, S. R. (2002): Leaves and fruits of Davidia (Cornales) from the Paleocene of North America. - Syst. Bot., 27(2): 368-382.

Manchester, S. R., Chen, Z.-D. (1996): Palaeocarpinus aspinosa sp. nov. (Betulaceae) from the Paleocene of Wyoming, USA. - Int. J. Plant Sci., 157: 644-655. http://dx.doi.org/10.1086/297386

Manchester, S. R., Chen, Z.-D. (1998): A new genus of Coryloideae (Betulaceae) from the Paleocene of North America. - Int. J. Plant Sci., 159: 522-532. http://dx.doi.org/10.1086/297569

Manchester, S. R., Dilcher, D. L. (1982): Pterocaryoid fruits (Juglandaceae) in the Paleogene of North America and their evolutionary and biogeographic significance. - Am. J. Bot., 69: 275-286. http://dx.doi.org/10.2307/2443015

Manchester, S. R., Dilcher, D. L. (1997): Reproductive and vegetative morphology of Polyptera (Juglandaceae) from the Paleocene of Wyoming and Montana. - Am. J. Bot., 84: 649-663. http://dx.doi.org/10.2307/2445902 PMid:21708618
Manchester, S. R., Guo, S.-X. (1996): Palaeocarpinus (extinct Betulaceae) from northwestern China: New evidence for Paleocene floristic continuity between Asia, North America and Europe. - Int. J. Plant Sci. - 157: 240-246. http://dx.doi.org/10.1086/297343

Manchester, S. R., Hickey, L. J. (2007): Reproductive and vegetative organs of Browniea gen. $n$. (Nyssaceae) from the Paleocene of North America. - Int. J. Plant Sci., 168(2): 229-249.

Manchester, S. R., Kodrul, T. M. (2014): Morphology, affinities and phytogeographic history of Porosia Hickey in the Cretaceous and Paleocene of North America and Asia. - Acta Palaeobot. 54(1): 77-99. http://dx.doi.org/10.2478/acpa-2014-0002

Manchester, S. R., Kress W. J. (1993): Fossil bananas (Musaceae): Ensete oregonense sp. nov. from the Eocene of western North America and its phytogeographic significance. - Am. J. Bot., 80: 1264-1272. http://dx.doi.org/10.2307/2445709

Manchester, S. R., Kvaček, Z. (2009): Fruits of Sloanea (Elaeocarpaceae) in the Paleogene of North America and Greenland. - Int. J. Plant Sci., 170(7): 941-950. http://dx.doi.org/10.1086/600148

Manchester, S. R. O'Leary, E. (2010): Distribution and identification of fin-winged fruits. - Bot. Rev., 76: 1-82. http://dx.doi.org/10.1007/s12229-010-9041-0

Manchester, S. R., Akhmetiev, M. A., Kodrul, T. (2002): Leaves and fruits of Celtis aspera (Newberry) comb. nov. (Celtidaceae) from the Paleocene of North America and eastern Asia. - Int. J. Plant Sci., 163: 725-736. http://dx.doi.org/10.1086/341513

Manchester, S. R., P. R. Crane, and D.L. Dilcher. (1991): Nordenskioldia and Trochodendron (Trochodendraceae) from the Miocene of northwestern North America. Bot. Gaz. 152: 357-368. http://dx.doi.org/10.1086/337898

Manchester, S. R., Crane, P. R., Golovneva, L. (1999): An extinct genus with affinities to extant Davidia and Camptotheca (Cornales) from the Paleocene of North America and Eastern Asia. - Int. J. Plant Sci., 160: 188-207. http://dx.doi.org/10.1086/314114

Manchester S. R., Pigg, K. B., Crane, P. R. (2004): Palaeocarpinus dakotensis sp. n. (Betulaceae: Coryloideae) and associated staminate catkins, pollen and leaves from the Paleocene of North Dakota. - Int. J. Plant Sci., 165: 1135-1148.

http://dx.doi.org/10.1086/423870

Manchester, S. R., Xiang, Q.-Y. (J.), Kodrul, T. M., Akhmetiev, M. A. (2009): Leaves of Cornus (Cornaceae) from the Paleocene of North America and Asia confirmed by trichome characters. - Int. J. Plant Sci., 170(1): 132-142. http://dx.doi.org/10.1086/593040

Manchester, S. R., Xiang, X.-P., Xiang, Q.-Y. (2010): Fruits of Cornelian Cherries (Cornaceae: Cornus Subg. Cornus) in the Paleocene and Eocene of the Northern Hemisphere. - Int. J. Plant Sci., 171(8): 882-891.

Manum, S. (1966): Ginkgo spitsbergensis n. sp. from the Paleocene of Spitsbergen and a siscussion of certain Tertiary species of Ginkgo from Europe and North America. - Norsk Polarinst. Årb. 1965, 49-58. 
Map-It. Accessed 2014. http://woodshole.er.usgs.gov/mapit/.

Maslova, N. P. (2002): A new plant of the family Platanaceae from the early Paleogene, reconstructed on the basis of leaves and inflorescences. - Paleontol. Zh., 2:, 89-101 [Paleontol. J. 36(2): 207-218].

Maslova. N. P. (2008): Association of vegetative and reproductive organs of platanoids (Angiospermae): Significance for systematics and phylogeny. - Paleontol. J., 42 (12): 1393-1404. http://dx.doi.org/10.1134/S0031030108120034

McIver, E. E., Basinger, J. F. (1987): Mesocyparis borealis gen et sp. nov.: fossil Cupressaceae from the early Tertiary of Saskatchewan, Canada. - Can. J. Bot., 65: 2338-2351.

http://dx.doi.org/10.1139/b87-318

McIver, E. E., Basinger, J. F. (1989): The morphology and relationships of Thuja polaris sp. nov. (Cupressaceae) from the early Tertiary, Ellesmere Island, Arctic Canada. - Can. J. Bot., 67: 1903-1915.

http://dx.doi.org/10.1139/b89-242

McIver, E. E., Basinger, J. F. (1990): Fossil seed cones of Fokienia (Cupressaceae) from the Paleocene Ravenscrag Formation of Saskatchewan, Canada. - Can. J. Bot., 68: 1609-1618. http://dx.doi.org/10.1139/b90-207

McIver, E. E., Basinger, J. F. (1993): Flora of the Ravenscrag Formation (Paleocene), southwestern Saskatchewan, Canada. - Palaeontogr. Can., 10: 1-167.

McNeill, J., Barrie, F. R., Buck, W. R., Demoulin, V., Greuter, W., Hawksworth, D. L., Herendeen, P. S., Knapp, S., Marhold, K., Prado, J., Prud'homme van Reine, W. F., Smith, G. F., Wiersema, J. H., Turland, N. J. (2012). International code of nomenclature for Algae, Fungi, and Plants (Melbourne Code). Regnum Vegetabile 154. Koeltz Scientific Books. 208 pp.

Moiseeva, M. G. (2008): New Angiosperms from the Maastrichtian of the Amaam Lagoon Area (Northeastern Russia). - Paleont. J., 42 (3): 313-327. (orig in Russian: Paleont. Zhurn., 2008(3): 92-105.)

Melchoir, R. C., Hall, J. W. (1983): Some megaspores and other small fossils from the Wannagan Creek site (Paleocene), North Dakota. - Palynology, 7: 1, 133-145. http://dx.doi.org/10.1080/01916122.1983.9989255

National Geologic Map Database. Accessed 2014. http://ngmdb.usgs.gov/ngmdb/ngmdb_home.html

Newberry, J. S. (1868): Notes on the later extinct floras of North America, with descriptions of some new species of fossil plants from the Cretaceous and tertiary strata. Lyceum Nat. Hist. New York Ann., 9: 1-76. http://dx.doi.org/10.1111/j.1749-6632.1870.tb00175.x

Newberry, J. S. (1878): Illustrations of Cretaceous and Tertiary plants of the western Territories of the United States. [publisher not indicated; see A. Hollick's explanation, p. $\mathrm{xV}$ in the editor's preface to Newberry (1898)].

Newberry, J. S. (1895): The flora of the Amboy clays. - U. S. Geol. Survey Mon. 26, p. 1-137, 58 pls.

Newberry, J. S. (1898): The later extinct floras of North America. - U. S. Geol. Surv. Monogr., 35: 1-295, 68 pls.

Nichols, D. J., Ott, H. L. (1978): Biostratigraphy and evolution of the Momipites-Caryapollenites lineage in the early Tertiary in the Wind River Basin, Wyoming. Palynology, 2: 93-112.
Nichols, D. J., Ott, H. L. (2006): Neotypes for Paleocene species in the Momipites-Caryapollenites pollen lineage. Palynology, 30(2006): 33-41.

http://dx.doi.org/10.1080/01916122.2006.9989617

http://dx.doi.org/10.2113/gspalynol.30.1.33

Paleobiology Database. Accessed 2014. Fossilworks. http://fossilworks.org.

Peppe, D. J. (2009): A high resolution chronostratigraphic study of the early Paleocene floral record in the northern Great Plains. - PhD dissertation, Yale University, New Haven, Connecticut. 590 pp.

Peppe, D. J. (2010): Megafloral change in the early and middle Paleocene in the Williston Basin, North Dakota, USA. - Palaeogeogr., Palaeoclimatol., Palaeoecol., 298(3-4): 224-234. http://dx.doi.org/10.1016/j.palaeo.2010.09.027

Peppe, D. J., Hickey, L. J. (2014): Fort Union Formation fossil leaves (Paleocene, Williston Basin, North Dakota, USA) indicate evolutionary relationships between Paleocene and Eocene plant species. - Bull. Peabody Mus. Nat. His. 55(2): 171-189. http://dx.doi.org/10.3374/014.055.0209

Peppe, D. J., Evans, D. A. D., \& Smirnov, A. V. (2009): Magnetostratigraphy of the Ludlow Member of the Fort Union Formation (Lower Paleocene) in the Williston Basin, North Dakota. Geol. Soc. Amer. Bull., 121(1-2): $65-79$.

Pepperberg, L. J. (1910): The Milk River Coal Field, Montana. - U. S. Geol. Surv. Bull., 381: 82-107.

Pepperberg, L. J. (1912): The southern extension of the Milk River Coal Bed, Chouteau County, Montana. - U. S. Geol. Surv. Bull., 471: 359-383.

Pigg, K. B., DeVore, M. L. (2010): Floristic composition and variation in late Paleocene to early Eocene floras in North America. - Bull. Geos., 85(1): 135-154. http://dx.doi.org/10.3140/bull.geosci.1136

Pigg K. B., DeVore, M. L., Wojciechowski, M. F. (2008): Paleosecuridaca curtisii gen. et sp. nov., Securidaca-like samaras (Polygalaceae) from the Late Paleocene of North Dakota, USA and their significance to the divergence of families within the Fabales. - Int. J. Plant Sci., 169: 1304-1313. http://dx.doi.org/10.1086/591981

Pigg, K. B., Stockey, R. A. (1991): Platanaceous plants from the Paleocene of Alberta, Canada. - Rev. Palaeobot. Palynol., 70: 125-146. http://dx.doi.org/10.1016/0034-6667(91)90082-E

Pigg, K.B., Manchester, S.R. and DeVore, M.L. (2008): Fruits of Icacinaceae (Tribe Iodeae) from the Late Paleocene of western North America. - Am. J. Bot., 95: 824-833. http://dx.doi.org/10.3732/ajb.2007340

Pishel, M. (1912): Lignite in the Fort Berthold Indian Reservation North Dakota, north of the Missouri River. - U. S. Geol. Surv. Bull., 471: 170-186.

Raven, P. H., Axelrod, D. I. (1974): Angiosperm biogeography and past continental movements. - Ann. Missouri Bot. Gard. 61: 539-673.

Read, R. W., Hickey, L. J. (1972): A revised classification of fossil palm and palm-like leaves. - Taxon, 21: 129-137. http://dx.doi.org/10.2307/1219237

Reeside, J. B. Jr. (1924): Upper Cretaceous and Tertiary Formations of the western part of the San Juan Basin of 
Colorado and New Mexico. - U. S. Geol. Surv. Prof. Paper, 134: 1-70.

Richardson, G. B. (1910): The Trinidad Coal Fields, Colorado. - U. S. Geol. Surv. Bull., 381: 379-446.

Richardson, G. B. (1911): The Monument Creek Group. Geol. Soc. Am. Bull., 23: 267-276.

Richardson, G. B. (1915): Description of the Castle Rock quadrangle, Colorado. - U. S. Geol. Surv. Geological Atlas, Castle Rock foilio 198.

Richardson, G. B. (1917): Note on the age of the Scranton Coal, Denver Basin, Colorado. - Am. J. Sci., 43: 243-244. http://dx.doi.org/10.2475/ajs.s4-43.255.243

Rothwell, G. W., Stockey, R. A. (1991): Onoclea sensibilis in the Paleocene of North America, a dramatic example of structural and ecological stasis. - Rev. Palaeobot. Palynol., 70(1-2): 113-124. http://dx.doi.org/10.1016/0034-6667(91)90081-D

Saporta, G. (1865): Études sur la végétation du sud-est de la France à l'époque tertiaire. - Ann. sci. nat., Bot., $5^{\text {th }}$ ser., 4: 5-264, pls. 1-13.

Saporta, G. (1868): Prodrome d'une flore fossile des travertine anciens de Sézanne. - Soc. géol. France Mém., 2d ser., 8: 289-436, pls. 1-15.

Schimper WP 1874 Traité de paléontologie végétale ou la flore du monde primitif dans ses rapports avec les Formations Géologiques et la Flora du Monde Actuel. Vol 3. JB Bailliére, Paris.

Schultz, A. R. (1910): The southern part of the Rock Springs Coal Field, Sweetwater County, Wyoming. - U. S. Geol. Surv. Bull., 381: 214-281.

Schweitzer, H.-J. (1974): Die Tertiären Koniferen Spitzbergens. - Palaeontogr. Abt. B Palaeophytol., 149: $1-89$.

Secord, R., Gingerich, P. D., Smith, M. E., Clyde, W. C., Wilf, P., \& Singer, B. S. (2006): Geochronology and mammalian biostratigraphy of middle and upper Paleocene continental strata, Bighorn Basin, Wyoming. - Amer. J. Sci., 306(4): 211-245. http://dx.doi.org/10.2475/ajs.306.4.211

Smith, C. D. (1910): The Fort Peck Indian Reservation lignite field, Montana. - U. S. Geol. Surv. Bull., 381: 40-59.

Sprain, C. J., Renne, P. R., Wilson, G. P., \& Clemens, W. A. (2014): High-resolution chronostratigraphy of the terrestrial Cretaceous-Paleogene transition and recovery interval in the Hell Creek region, Montana. - Geol. Soc. Amer. Bull., 126 (in press).

Stiehler, A. W. (1857): Beiträge zur Kenntniss der vorweltlichen Flora des Kreidegebirges im Harze. II. Die Flora des Langeberges bei Quedlinburg. - Palaeontographica, 5: 71-80.

Stockey, R. A., Manchester, S. R. (1988): A fossil flower with in situ Pistillipollenites from the Eocene of British Columbia. - Can. J. Bot., 66: 313-318. http://dx.doi.org/10.1139/b88-051

Stockey, R. A., Rothwell, G. W. (1997): The aquatic angiosperm Trapago angulata from the upper Cretaceous (Maastrichtian) St. Mary River Formation of southern Alberta. - Int. J. Plant Sci., 158(1): 83-94. http://dx.doi.org/10.1086/297417

Stockey, R. A., Hoffman, G. L., Rothwell, G. W. (1997): The fossil monocot Limnobiophyllum scutatum: Resolving the phylogeny of Lemnaceae. - Am. J. Bot., 84: 355-368. http://dx.doi.org/10.2307/2446009

PMid:21708589

Stockey, R. A., Hoffman, G. L., Rothwell, G. W. (2013): Paleobotany and paleoecology of Gao Mine, a late Paleocene fossil locality near Red Deer, Alberta, Canada. - Can. J. Earth Sci., 50: 235-248.

http://dx.doi.org/10.1139/cjes-2012-0073

Stockey, R.A, Hoffman, G.L., Vavrek, M. J. (2014): Paleobotany and Palynology of the Munce's Hill fossil locality near Red Deer, Alberta, Canada. Ch. 13, pp. 367-388 in W.D. Stevens, O. M Montiel and P.H. Raven, eds. Paleobotany and biogeography. Missouri Botanical Garden Press, St. Louis, 404 pp.

Stockey, R. A., Lantz, T. C., Rothwell, G. W. (2006): Speirseopteris orbiculata gen. et sp. nov. (Thelypteridaceae), A derived fossil filicalean from the Paleocene of western North America. - Int. J. Plant Sci. 167(3): 729-736. http://dx.doi.org/10.1086/501233

Stockey, R. A., Rothwell, G. W., Falder, A. B. (2001): Diversity among taxodioid conifers: Metasequoia foxii sp. nov. from the Paleocene of central Alberta, Canada. Int. J. Plant Sci., 162(1): 221-234. http://dx.doi.org/10.1086/317914

Stone, R. W., Calvert, W. R. (1910): Stratigraphic relations of the Livingston Formation of Montana. Econ. Geol., 5: 551-557.

http://dx.doi.org/10.2113/gsecongeo.5.7.652 http://dx.doi.org/10.2113/gsecongeo.5.8.741 http://dx.doi.org/10.2113/gsecongeo.5.6.551

Stone, R. W., Lupton, C. T. (1910): The Powder River Coal Field, Wyoming, adjacent to the Burlington Railroad. U. S. Geol. Surv. Bull., 381: 115-136.

Stull, G. W., Herrera, F., Manchester, S. R., Jaramillo, C., Tiffney, B. H. (2012): Fruits of an "Old World" tribe (Phytocreneae; Icacinaceae) from the Paleogene of North and South America. - Syst. Bot., 37 (3): 784-794. http://dx.doi.org/10.1600/036364412X648724

Sun, F., Stockey, R. A. (1992): A new species of Palaeocarpinus (Betulaceae) based on infructescences, fruits, and associated staminate inflorescences and leaves from the Paleocene of Alberta, Canada. - Int. J. Plant Sci., 153: 136-146. http://dx.doi.org/10.1086/297015

Tanai, T. (1979): Late Cretaceous floras from the Kuji district, northeastern Honshu, Japan. - Jour. Fac. Sci. Hokkaido Univ. Ser. 4, 19(1-2): 75-136.

Tidwell, W. D., Parker, L. R. (1987): Aurealcaulis crossii gen. et sp. nov., An arborescent, osmundaceous trunk from the Fort Union Formation (Paleocene), Wyoming. - Am. J. Bot., 74 (6): 803-812. http://dx.doi.org/10.2307/2443861

Topographic maps. Accessed 2014. U. S. Dept. Int., U. S. Geol. Surv. http:/geonames.usgs.gov/pls/topomaps/

Turland, N. (2013): The code decoded. A user's guide to the International Code of Nomenclature for algae, fungi, and plants. Regnum Vegetabile, 155: 1-169.

Unger, F. (1850): Die Gattung Glyptostrobus in der TertiärFormation. - Sitzungsberichte Kaiserl. Akad. Wissensch. Wein, Math.-Naturwiss., Classe 5: 434-435.

Upchurch, G. R., Jr., Dilcher, D. L. (1990): Cenomanian angiosperm leaf megafossils, Dakota Formation, Rose 
Creek Locality, Jefferson County, Southeastern Nebraska. - U.S. Geol. Surv. Bull., 1915: 1-55.

Upchurch, G. R., Jr., Wolfe, J. A. (1987): Extinction patterns in Laurales at the Cretaceous-Tertiary boundary. - Am. J. Bot., 74: 692-693. Abstr.

Veatch, A. C. (1907): Geography and geology of a portion of southwestern Wyoming. - U.S. Geol. Surv. Prof. Paper, 316: 1-178.

Wang, Q. (2012): Nomenclatural notes on Leguminosites and several taxonomically relevant names (fossil Leguminosae). - Taxon, 61(4): 871-877.

Wang Yan-Hui, Ferguson D. K., Feng, G.-P., Wang, Y.-F., Zhilin, S.G., Li, C.-S., Popova-Tselenkova, S., Yang, J., Ablaev, A. G. (2009): The Phytogeography of the extinct angiosperm Nordenskioeldia (Trochodendraceae) and its response to climate changes. - Palaeogeogr. Palaeoclimat. Palaeoecol., 280: 183-192. http://dx.doi.org/10.1016/j.palaeo.2009.05.019

Ward, L. F. (1885a): Report of Mr. Lester F. Ward. - In: Powell, J.W. et al. (eds), Fifth Annual Report of the United States Geological Survey 1883-84, pp. U.S. Geol. Survey, Washington.

Ward, L. F. (1885b): Synopsis of the flora of the Laramie group. - U. S. Geol. Surv. Ann. Rep., 6: 400-570.

Ward, L. F. (1887): Types of the Laramie flora. - U. S. Geol. Surv. Bull., 37: 1-117.

Washburne, C. W. (1910): The South Park Coal Field, Colorado. - U. S. Geol. Surv. Bull., 381: 307-316.

Watt, A. D. (1971): Validation of names of species of fossil plants described by RW Brown in 1962. - Taxon, 20(4): 639-640. http://dx.doi.org/10.2307/1218282

Watt, A. D. (1975): A new name for Rhamnus hirsuta Brown ex Watt. - Taxon, 24(4): 488. http://dx.doi.org/10.2307/1219502

Weber O 1852 Die Tertiärerflora der Niederrheinischen Braunkohlenformation. Palaeontographica 2:115-236, pls 18-25.

Weed, W. H. (1898): Description of the Little Belt Moutains Quadrangle, Montana. - U. S. Geol. Surv. Atlas, Folio 56, 11 p., 4 maps.

Wegemann, C. H. (1912): The Sussex Coal Field, Johnson, Natrona, and Converse Counties, Wyoming. - U. S. Geol. Surv. Bull., 471: 441-471.

Wilf, P. (2002): Late Paleocene-early Eocene climate changes in southwestern Wyoming: Paleobotanical analysis. Geol. Soc. Am. Bull., 112(2): 292-307.

Wilf, P., Beard, K. C., Davies-Vollum, K. S., Norejko, J. W. (1998). Portrait of a late Paleocene (early Clarkforkian) terrestrial ecosystem; Big Multi Quarry and associated strata, Washakie Basin, southwestern Wyoming. Palaios, 13(6), 514-532.

http://dx.doi.org/10.2307/3515344

Winchester, D. E. (1912): The Lost Springs Coal Field, Converse County, Wyoming. - U. S. Geol. Surv. Bull., 471: 472-515.
Winchester, D. E., Haies, C. J., Lloyd, E. R., Parks, E. M. (1916): The lignite field of northwestern South Dakota. U. S. Geol. Surv. Bull., 627: 1-178.

Wing, S. L. (1998): Late Paleocene-early Eocene floral and climatic change in the Bighorn Basin, Wyoming. Late Paleocene-Early Eocene climatic and biotic events in the marine and terrestrial records. In: Aubry, M., Lucas S., Berggren W. (eds.): Late Paleocene-Early Eocene Biotic and Climatic Events. pp. 371-391, Columbia University Press, New York.

Wing, S. L, Alroy, J., Hickey, L. J. (1995): Plant and mammal diversity in the Paleocene to early Eocene of the Bighorn Basin. - Palaeogeogr. Palaeoclimat. Palaeoecol., 115: 117-155. http://dx.doi.org/10.1016/0031-0182(94)00109-L

Wing, S. L., Currano, E. D. (2013): Plant response to a global greenhouse event 56 million years ago. - Amer. J. Bot., 100(7): 1234-1254. http://dx.doi.org/10.3732/ajb.1200554

Wolfe, J. A. (1966): Tertiary plants from the Cook Inlet region, Alaska. - U. S. Geol. Surv. Prof. Paper, 398-B: $1-32$.

Wolfe, J. A. (1977): Paleogene floras from the Gulf of Alaska region. - Geol. Surv. Prof. Paper, 997: 1-108.

Wolfe, J. A.; Tanai, T. (1987): Systematics, phylogeny, and distribution of Acer (maples) in the Cenozoic of western North America. - J. Fac. Sci. Hokkaido Univ. Ser. 4, 22(1): 1-246.

Wolfe, J. A., Wehr, W. C . (1987): Middle Eocene dicotyledonous plants from Republic, Northeastern Washington. U. S. Geol. Surv. Bull., 1597: 1-25.

Woodruff, E. G. (1909): The Red Lodge Coal Field, Montana. - U. S. Geol. Surv. Bull., 341: 92-107.

Woolsey, L. H., Richards, R. W., Lupton, C. T. (1917): The Bull Mountain Coal Field, Musselshell and Yellowstone Counties, Montana. U.S. Government Printing Office, $218 \mathrm{p}$.

Yen, T.-G. (1952): Molluscan Fauna of the Morrison Formation. - U. S. Geol. Surv. Prof. Paper, 233-B: 1-51.

Zetter, R., Farabee, M. J., Pigg, K. B., Manchester, S. R., DeVore, M. L., Nowak, M, D. (2011): Palynoflora of the late Paleocene silicified shale at Almont, North Dakota, USA. - Palynology, 35: 1-33. http://dx.doi.org/10.1080/01916122.2010.501164

Zhou, Z., Quan, C., Liu Y.-S. C. (2012): Tertiary Ginkgo ovulate organs with associated leaves from North Dakota, USA, and their evolutionary significance. - Int. J. Plant Sci., 173: 67-80. http://dx.doi.org/10.1086/662651 
Table 1. Current taxonomic assignments compared with the designations of Brown 1962.

\begin{tabular}{|c|c|c|}
\hline Phylogenetic position & Current assignment $^{1}$ & Old name from Brown (1962) \\
\hline Marchantiaceae & "Marchantia" lignitica (WARD) R. W. BROWN & Marchantia lignitica (WARD) R. W. BROWN \\
\hline Marchantiaceae & "Marchantia" pealei KNOWLTON & Marchantia pealei KNOWLTON \\
\hline Marchantiaceae & Preissites wardii KNOWLTON & Preissites wardii KNOWLTON \\
\hline Moss & "Hypnum" coloradense R. W. BROWN & Hypnum coloradense R. W. BROWN \\
\hline Moss & "Mnium" montanense R. W. Brown & Mnium montanense $\mathrm{R} . \mathrm{W}$. BROWN \\
\hline Isoetaceae & $\begin{array}{l}\text { Isoetites horridus (DAWSON) R. W. BROWN } \\
\text { and Minerosporites dissimilis }\end{array}$ & Isoetites horridus (DAWSON) R. W. BROWN \\
\hline Selaginellaceae & Selaginella berthoudii LESQUEREUX & Selaginella berthoudii LESQUEREUX \\
\hline Selaginellaceae & Selaginella collieri KNOWLTON & Selaginella collieri KNOWLTON \\
\hline Selaginellaceae & Selaginella monstrosa (HOLLICK) R. W. BROWN & Selaginella monstrosa (HOLLICK) R. W. BROWN \\
\hline Sphenophyte & Equisetum spp. & Equisetum spp \\
\hline Schizaeaceae & "Anemia" elongata (NEWBERRY) KNOWLTON & Anemia elongata (NEWBERRY) KNOWLTON \\
\hline Schizaeaceae & Lygodium coloradense KNOWLTON & Lygodium coloradense KNOWLTON \\
\hline Osmundaceae & Osmunda greenlandica (HEER) R. W. BROWN & Osmunda greenlandica (HEER) R. W. BROWN \\
\hline Osmundaceae & Osmunda macrophylla PeNHALLOW & Osmunda macrophylla PeNHALLOW \\
\hline Onocleaceae & Onoclea hesperia R. W. BROWN & Onoclea hesperia $\mathrm{R} . \mathrm{W} . \mathrm{BROWN}$ \\
\hline Dennstaedtiaceae & Dennastra sorimarginata MCIVER et BASINGER & Saccoloma gardneri (LESQUEREUX) KNOWLTON \\
\hline Dennstaedtiaceae & "Dennstaedtia" americana KNOWLTON (possibly Coniopteris) & Dennstaedtia americana KNOWLTON \\
\hline Blechnaceae & Woodwardia arctica (HEER) R. W. BROWN & Woodwardia arctica (HEER) R. W. BROWN \\
\hline Fern & Allantodiopsis erosa (Lesquereux) KNOWLTON et MAXON & Allantodiopsis erosa (LESQUEREUX) KNOWLTON et MAXON \\
\hline Fern & "Blechnum" anceps (LESQUEREUX) R. W. BROWN & Blechnum anceps (LESQUEREUX) R. W. BROWN \\
\hline Fern & "Hymenophyllum" confusum LESQUEREUX & Hymenophyllum confusum LESQUEREUX \\
\hline Fern & "Dryopteris" lakesii (LESQUEREUX) KNOWLTON & Dryopteris lakesii (LESQUEREUX) KNOWLTON \\
\hline Fern & "Dryopteris" meeteetseana R. W. BRowN & Dryopteris meeteetseana $\mathrm{R} . \mathrm{W}$. BROWN \\
\hline Fern & "Dryopteris" serrata R. W. BROWN & Dryopteris serrata $\mathrm{R} . \mathrm{W}$. BROWN \\
\hline Fern & "Lastrea" goldiana (LESQUEREUX) LESQUEREUX & Lastrea goldiana (LESQUEREUX) LESQUEREUX \\
\hline Fern & “Gleichenia" hesperia R. W. Brown ex WATT & Gleichenia hesperia $\mathrm{R}$. W. BROWN ex WATT \\
\hline cycad & "Zamia" coloradensis (KNOWLTON) R. W. BROWN & Zamia coloradensis (KNOWLTON) R. W. BROWN \\
\hline cycad & "Zamia" wyomingensis R. W. BROWN & Zamia wyomingensis R. W. BROWN \\
\hline cycad & Eostangeria pseudopteris KVAČEK et MANCHESTER & $n a$ \\
\hline Ginkgoaceae & Ginkgo cranei ZHOU, QUAN et LIU & Ginkgo adiantoides (UNGER) HEER \\
\hline Amentotaxaceae & Amentotaxus gladifolia (LUDWIG) FERGUSON, JäHNICHEN et ALVIN & Amentotaxus campbellii (GARDNER) FLORIN \\
\hline ?Araucariaceae & "Araucaria" longifolia (LESQUEREUX) R. W. BROWN & Araucaria longifolia (LESQUEREUX) R. W. BROWN \\
\hline Cupressaceae & Glyptostrobus europaeus (BRONGNIART) UNGER & Glyptostrobus nordenskioldii (HEER) R. W. BROWN \\
\hline Cupressaceae & $\begin{array}{l}\text { Metasequoia occidentalis (NEWBERRY) CHANEY; } \\
\text { Metasequoia foxii STOCKEY, ROTHWELL et FALDER }\end{array}$ & Metasequoia occidentalis (NEWBERRY) CHANEY \\
\hline Cupressaceae & "Taxodium" olrikii (HEER) R. W. BROWN & Taxodium olrikii (HEER) R. W. BROWN \\
\hline Cupressaceae & $\begin{array}{l}\text { Ditaxocladus catenulatus (W.A. BELL) S.X. GUO, Z. KVAŽEK, } \\
\text { MANCHESTER et Z.K. ZHOU }\end{array}$ & Fokienia catenulata $(\mathrm{BELL}) \mathrm{R}$. W. BROWN \\
\hline Cupressaceae & Mesocyparis borealis MCIVER et BASINGER & Thuja interrupta NEWBERRY \\
\hline Nymphaeaceae & Nymphaea pulchella (KNOWLTON) R. W. BROWN & Nymphaea pulchella (KNOWLTON) R. W. BROWN \\
\hline Nymphaeaceae & Paleonuphar hesperium R. W. BROWN & Paleonuphar hesperium R. W. BROWN \\
\hline ?Nymphaeaceae & "Nymphaea" leei (KNOWLTON) R. W. BROWN & Nymphaea leei (KNOWLTON) R. W. BROWN \\
\hline Magnoliaceae & cf. Liriodendron. "Bauhinia" wyomingana R. W. BROWN & Bauhinia wyomingana $\mathrm{R}$. W. BRowN \\
\hline Lauraceae & “Cinnamomum” sezannense WATELET & Cinnamomum sezannense WATELET \\
\hline Lauraceae & "Laurus" socialis LESQUEREUX & Laurus socialis LESQUEREUX \\
\hline Lauraceae & "Lindera" obtusata (WARD) R. W. BROWN & Lindera obtusata (WARD) R. W. BROWN \\
\hline Lauraceae & "Persea" brossiana LESQUEREUX & Persea brossiana LESQUEREUX \\
\hline Lauraceae & "Sassafras" thermale (LESQUEREUX) R. W. BROWN & Sassafras thermale (LESQUEREUX) R. W. BROWN \\
\hline Lauraceae & Laurophyllum caudatum (KNOWLTON) R. W. BROWN & Laurophyllum caudatum (KNOWLTON) R. W. BROWN \\
\hline Lauraceae & Laurophyllum perseanum R. W. BROWN ex WATT & Laurophyllum perseanum R. W. BROWN ex WATT \\
\hline Lauraceae & "Melastomites" montanensis R. W. Brown ex WATT & Melastomites montanensis R. W. Brown ex WATT \\
\hline Lauraceae & "Artocarpus" lessigiana (LESQUEREUX) KNOWLTON & Artocarpus lessigiana (LESQUEREUX) KNOWLTON \\
\hline Chloranthaceae & cf. Crassidenticulum UPCHURCH et DILCHER (1991) & Myrtophyllum torreyi (LESQUEREUX) DORF \\
\hline ?Gramineae & "Grasslike monocotyledons" & Grasslike monocotyledons \\
\hline ? Alismataceae & Haemanthophyllum sp. 3 (Golovneva 1997) & Alismaphyllites grandifolius (PENHALLOW) R. W. BROWN \\
\hline Zingiberales & Canna? magnifolia KNOWLTON & Canna? magnifolia KNOWLTON \\
\hline Zingiberales & Zingiberites dubius LESQUEREUX & Zingiberites dubius LESQUEREUX \\
\hline Zingiberales & Ensete goldianum (LESQUEREUX) comb. nov. (seeds) & Viburnum goldianum LESQUEREUX seeds \\
\hline Araceae & Limnobiophyllum scutatum (DAWSON) KRASSILOV & Hydromystria expansa (HEER) HANTKE \\
\hline Palmae & "Chamaedorea" danae (LESQUEREUX) BERRY & Chamaedorea danae (LESQUEREUX) BERRY \\
\hline Palmae & Palmacites dorfi (R. W. BROWN) READ et HICKEY & Thrinax dorfii R. W. BROWN \\
\hline
\end{tabular}

${ }^{1}$ Binomials apply to leaves unless otherwise indicated. 


\begin{tabular}{|c|c|c|}
\hline Phylogenetic position & Current assignment & Old name from Brown (1962) \\
\hline Palmae & Paloreodoxites plicatus (LESQUEREUX) KNOWLTON & Paloreodoxites plicatus (LESQUEREUX) KNOWLTON \\
\hline Palmae & Sabal imperialis DAWSON & Sabal imperialis DAWSON \\
\hline Palmae & Sabalites grayana (LESQUEREUX) KNOWLTON & Sabal grayana LESQUEREUX \\
\hline Palmae & Sabalites powellii (NEWBERRY) E.W. BERRY & Sabal powellii NEWBERRY \\
\hline ?Palmae & "Palmocarpon" commune LESQUEREUX (fruit) & Palmocarpon commune LESQUEREUX \\
\hline ?Palmae & "Palmocarpon" compositum LESQUEREUX (fruit) & Palmocarpon compositum LESQUEREUX \\
\hline ?Palmae & "Palmocarpon" lineatum LESQUEREUX (fruit) & Palmocarpon lineatum LESQUEREUX \\
\hline ?Palmae & "Palmocarpon" subcylindricum LESQUEREUX & Palmocarpon subcylindricum LESQUEREUX \\
\hline ?Palmae & "Palmocarpon" truncatum LESQUEREUX & Palmocarpon truncatum LESQUEREUX \\
\hline Sabiaceae & $\begin{array}{l}\text { Meliosma rostellata (LESQUEREUX) CRANE, MANCHESTER } \\
\text { et DILCHER (fruit) }\end{array}$ & Carpites rostellatus LESQUEREUX \\
\hline Nelumbonaceae & $\begin{array}{l}\text { Nelumbago montanum (R. W. BROWN ex WATT) MCIVER } \\
\text { et BASINGER (leaf and fruit) }\end{array}$ & $\begin{array}{l}\text { Nelumbium montanum R. W. BROWN ex WATT leaf and } \\
\text { associated fruit }\end{array}$ \\
\hline Nelumbonaceae & Nelumbium tenuifolium LESQUEREUX & Nelumbium tenuifolium LESQUEREUX \\
\hline Nelumbonaceae & Paleonelumbo macroloba KNOWLTON & Paleonelumbo macroloba KNOWLTON \\
\hline Platanaceae & Macginitiea gracilis (LESQUEREUX) J. WOLFE et WEHR & $\begin{array}{l}\text { Platanus nobilis LESQUEREUX (5-lobed laminae) sensu } \\
\text { Brown } 1962\end{array}$ \\
\hline Platanaceae & Macginitiea nobilis (NEWBERRY) comb. nov. & $\begin{array}{l}\text { Platanus nobilis NEWBERRY (3-lobed laminae) sensu } \\
\text { Brown } 1962\end{array}$ \\
\hline Platanaceae & Macginitistemon mikanoides (MACGINITIE) MANCHESTER (stamens) & "Calyx of a flower" (Brown 1962, pl. 68, figs 27-29) \\
\hline Platanaceae & Macginicarpa sp. (infructescences) & Sparganium antiquum (NEWBERRY) BERRY \\
\hline Platanaceae & Platanites raynoldsii (NEWBERRY) comb. nov. & Platanus raynoldsii NEWBERRY \\
\hline Platanaceae & Platanites marginata (LESQUEREUX) K. JOHNSON & Cissus marginata (LESQUEREUX) R. W. BROWN \\
\hline ?Platanaceae & Dyrana flexuosa (NEWBERRY) GOLOVNEVA & Quercus sullyi NEWBERRY \\
\hline Trochodendraceae & $\begin{array}{l}\text { Nordenskioeldia borealis HEER (fruit) and Ziziphoides } \\
\text { flabellum (NEWBERrY) CRANE, MANCHESTER et DILCHER }\end{array}$ & $\begin{array}{l}\text { Nordenskioldia borealis HEER (R. W. BROWN 1962, } \\
\text { pl. 67, figs 13, 45), and "seeds with papillose inner } \\
\text { surface" (Pl. 67, figs 9, 10, 14-16, 20, 22, 23) }\end{array}$ \\
\hline Cercidiphyllaceae & $\begin{array}{l}\text { Trochodendroides genetrix (NEWBERRY) comb. nov. + Nyssidium } \\
\text { arcticum (HEER) ILJNSKAYA. Brown's concept also included leaves } \\
\text { of Zizyphoides flabellum }\end{array}$ & Cercidiphyllum arcticum (HEER) R. W. BROWN (part). \\
\hline Cercidiphyllaceae & Archeampelos acerifolia (NEWBERRY) MclvER et BASINGER (1993) & Ampelopsis acerifolia (NEWBERRY) R. W. BROWN \\
\hline Cercidiphyllaceae & winged seed probably from a Nyssidum fruit & Liquidambar dakotense R. W. BROWN ex WATT \\
\hline ?Hamamelidaceae & Hamamelites inaequalis (NEWBERRY) R. W. BROWN & Hamamelites inaequalis (NEWBERRY) R. W. BROWN \\
\hline Hamamelidaceae & Hamamelidaceae fruiting raceme & $\begin{array}{l}\text { Longitudinal hollow studded with bilobed projections } \\
\text { (pl. } 65 \text {, fig. 44) }\end{array}$ \\
\hline Cucurbitaceae & Cucurbitaciphyllum lobatum (KNOWLTON) comb. nov. & Vitis lobata (KNOWLTON) R. W. BROWN \\
\hline Fagaceae & "Castanea" intermedia LESQUEREUX & Castanea intermedia LESQUEREUX \\
\hline ?Fagaceae & Fagopsiphyllum groenlandicum (HEER) MANCHESTER & Quercus greenlandica HEER \\
\hline ?Fagaceae & "Quercus" asymmetrica TRELEASE & Quercus asymmetrica TRELEASE \\
\hline ?Fagaceae & "Quercus macneilii" R. W. BROWN & Quercus macneilii R. W. BROWN \\
\hline ?Fagaceae & "Quercus" yulensis R. W. BROWN & Quercus yulensis R. W. BROWN \\
\hline ?Betulaceae & "Betula" stevensonii LESQUEREUX & Betula stevensonii LESQUEREUX \\
\hline Betulaceae & Palaeocarpinus joffrense SUN et STOCKEY (infructescence and fruit) & Burlike objects \\
\hline Betulaceae & Cranea wyomingensis MANCHESTER et CHEN (seeds) & unknown \\
\hline Juglandaceae & $\begin{array}{l}\text { Cyclocarya brownii MANCHESTER et DILCHER (fruits), } \\
\text { Cyclocarya hispida (R. W. BROWN) comb. nov. }\end{array}$ & Pterocarya hispida $\mathrm{R}$. W. BROWN ex Watt \\
\hline Juglandaceae & Juglandicarya simplicarpa MANCHESTER (fruit) & Juglandicarya spp. \\
\hline Juglandaceae & $\begin{array}{l}\text { Polyptera manningii MANCHESTER et DILCHER (fruit), } \\
\text { Juglandiphyllites glabra (R. W. BROWN ex WATT) MANCHESTER } \\
\text { et DILCHER }\end{array}$ & Pterocarya glabra $\mathrm{R}$. W. BROWN ex WATT \\
\hline Juglandaceae & "Carya" antiquorum NEWBERRY & Carya antiquorum NEWBERRY \\
\hline Rhamnaceae & Rhamnites cleburnii (LESQUEREUX) MCIVER et BASINGER & $\begin{array}{l}\text { Rhamnus cleburnii LESQUEREUX, and "Magnolia" regalis } \\
\text { HEER sensu Brown }\end{array}$ \\
\hline Rhamnaceae & "Rhamnus" goldiana LESQUEREUX & Rhamnus goldiana LESQUEREUX \\
\hline Rhamnaceae & Zizyphus fibrillosus (LESQUEREUX) LESQUEREUX & Zizyphus fibrillosus (LESQUEREUX) LESQUEREUX \\
\hline Rhamnaceae & cf. "Rhamnus" goldiana LESQUEREUX & Magnolia regalis HEER \\
\hline ?Rhamnaceae & Paliurus? sp. & Paliurus? fruit of Berry (1930) \\
\hline Malvaceae & Penosphyllum cordatum (WARD) HICKEY & Pterospermites cordatus WARD \\
\hline Rutaceae? & $\begin{array}{l}\text { Porosia verrucosa (LESQUERUEX) HICKEY emend. } \\
\text { MANCHESTER ET KODRUL (fruit) }\end{array}$ & Hydromystria expansa (HEER) HANTKE (part) \\
\hline Sapindaceae & Acer sp. fruit & Acer spp. \\
\hline Sapindaceae & Aesculus hickeyi MANCHESTER (leaf, leaflets and fruit) & $\begin{array}{l}\text { Carya antiquorum NEWBERRY (most of the leaflets figured } \\
\text { by Brown, but not the type specimens of Newberry) }\end{array}$ \\
\hline ?Sapindaceae & Deviacer wolfei MANCHESTER (fruit) & $\begin{array}{l}\text { "Maplelike samaras, but probably of sapindaceous } \\
\text { affinity" (Brown 1962, pl. 67, figs 6, 7) }\end{array}$ \\
\hline
\end{tabular}




\begin{tabular}{|c|c|c|}
\hline Phylogenetic position & Current assignment & Old name from Brown (1962) \\
\hline Leguminosae & Indet Leguminosae pods & Robinia wardii (KNOWLTON) R. W. BROWN \\
\hline Leguminosae & Pod of Leguminosae or Bignoniaceae or other plant & Leguminosites coloradensis KNOWLTON \\
\hline Cannabaceae & $\begin{array}{l}\text { Celtis asperum (Newberry) MANCHESTER, AKHM. } \\
\text { et KODRUL (leaf and fruit) }\end{array}$ & Viburnum asperum (NEWBERRY) R. W. BROWN \\
\hline Ulmaceae & Ulmites microphylla (NEWBERRY) comb. nov. & $\begin{array}{l}\text { Planera microphylla NEWBERRY; Zelkova planeroides } \\
\text { (WARD) R. W. Brown }\end{array}$ \\
\hline ?Rosaceae & Prunites mclearnii (Berry) MCIVER et BASINGER & Prunus mclearnii BERRY \\
\hline ?Rosaceae & "Persea" brossiana LESQUEREUX & Persea brossiana LESQUEREUX \\
\hline ?Rosaceae & "Prunus" careyhurstia R. W. Brown ex WATT & Prunus careyhurstia $\mathrm{R}$. W. BROWN ex WATT \\
\hline ?Rosaceae & "Prunus" coloradensis KNOWLTON & Prunus coloradensis KNOWLTON \\
\hline Vitaceae & Vitis or Ampelocissus sp. (seed) & Vitis sp. seed \\
\hline Polygonaceae & Paranymphaea crassifolia (NEWBERRY) BERRY & Paranymphaea crassifolia (NEWBERRY) BERRY \\
\hline Polygonaceae & Podopterus antiqua MANCHESTER et O'LEARY (winged fruit) & $\begin{array}{l}\text { Ulmus rhamnifolia WARD (Brown 1962, pl. 24, fig. 18, } \\
\text { as winged fruit) }\end{array}$ \\
\hline Polygonaceae & Polygonocarpum curtisii MANCHESTER et O'LEARY (winged fruit) & $\begin{array}{l}\text { Ulmus rhamnifolia Ward in Brown 1962, pl. 24, fig. } 17 \\
\text { (winged fruit) }\end{array}$ \\
\hline Ericaceae & "Kalmia" elliptica R. W. BROWN & Kalmia elliptica R. W. BROWN \\
\hline Cornaceae & Cornus swingii MANCHESTER, XIANG, KodRUl et AKHMETIEV & $\begin{array}{l}\text { Cornus hyperborea HEER (part) and C. nebrascensis } \\
\text { SCHIMPER (part, non type) }\end{array}$ \\
\hline Nyssaceae & $\begin{array}{l}\text { Beringiaphyllum cupanioides (NEWBERRY) MANCHESTER, } \\
\text { CRANE et GOLOVNEVA }\end{array}$ & Viburnum cupanioides (NEWBERRY) R. W. BROWN \\
\hline Nyssaceae & $\begin{array}{l}\text { Browniea serrata (NEWBERRY) MANCHESTER et HICKEY } \\
\text { (leaf, infructescence, fruit, and flowers) }\end{array}$ & $\begin{array}{l}\text { Eucommia serrata (NEWBERRY) R. W. BROWN } \\
\text { leaves and "Probably fruits with remnants of calyces" } \\
\text { (Brown 1962, pl. 67, figs 11, 12, 17); "Calyx of a flower" } \\
\text { (pl. 67, fig. 46) }\end{array}$ \\
\hline Nyssaceae & Davidia antiqua (NEWBERRY) MANCHESTER (leaf and fruit) & $\begin{array}{l}\text { Viburnum antiquum (NEWBERRY) HOLLICK (leaves) and } \\
\text { Viburnum tilioides WARD (fruits) }\end{array}$ \\
\hline Icacinaceae & $\begin{array}{l}\text { Icacinicaryites linchensis PIGG, MANCHESTER et DEVORE } 2008 \\
\text { (fruit) }\end{array}$ & Prunus corrugis R. W. BROWN ex WATT (smaller fruits) \\
\hline Icacinaceae & $\begin{array}{l}\text { Icacinicaryites corruga (R. W. BROWN) PIGG, MANCHESTER } \\
\text { et DEVore (fruit) }\end{array}$ & Prunus corrugis R. W. BROWN ex WATT (large fruit) \\
\hline Icacinaceae & Palaeophytocrene piggae STULL (fruit) & $\begin{array}{l}\text { Impression of a seed showing pits arranged in longitudinal } \\
\text { rows (Brown 1962, pl. 67, fig. 26) }\end{array}$ \\
\hline Bignoniaceae & Bignoniaceae (seed) & Two-winged seeds (Brown 1962, pl. 68, figs 17-22 \\
\hline Elaeocarpaceae & Sloanea ungeri (HEER) MANCHESTER et Z. KVAČEK (fruit) & $\begin{array}{l}\text { Carpolithes spinosus Newberry, "Elliptic fruit with } \\
\text { a fringe of hairs or filaments" Brown 1962, pl. 67, fig. 35) }\end{array}$ \\
\hline Incertae Sedis & $\begin{array}{l}\text { Dicotylophyllum silberlingi (R. W. BROWN) } \\
\text { J. WOLFE et TANAI } 1987\end{array}$ & Acer silberlingii $\mathrm{R}$. W. BROWN \\
\hline Incertae Sedis & Dicotylophyllum triloba (NEWBERRY) J. WOLFE et TANAI & Acer newberryi R. W. BROWN \\
\hline Incertae Sedis & Dicotylophyllum hansonium PEPPE et HICKEY & Vitis olrikii HEER sensu R.W. BROWN \\
\hline Incertae Sedis & Averrhoites affinis (NEWBERRY) HICKEY & Sapindus affinis (NEWBERRY) R. W. BROWN \\
\hline Incertae Sedis & Quereuxia angulata (NEWBERRY) Kryshtofovich & $\begin{array}{l}\text { Trapa angulata (NEWBERRY) R. W. BROWN, and Trapa } \\
\text { paulula (BELL) R. W. BROWN, and Cabomba inermis } \\
\text { (NEWBERRY) HOLLICK }\end{array}$ \\
\hline Incertae Sedis & "Koelreuteria" annosa R. W. BROWN (fruit) & Koelreuteria annosa R. W. BROWN \\
\hline Incertae Sedis & Leepierceia preartocarpoides (R. W. BROWN) K. JoHNSON & $\begin{array}{l}\text { Ficus artocarpoides (LESQUEREUX) R. W. BROWN (just one } \\
\text { of Brown's illustrated specimens reassigned (1962, pl. 28, } \\
\text { fig. 4) by Johnson (1996) }\end{array}$ \\
\hline Incertae Sedis & Mciveraephyllum nebrascense (SCHIMPER) comb. nov. & $\begin{array}{l}\text { Ficus artocarpoides LESQUEREUX sensu BROWN (except } \\
\text { one of Brown's figured specimens, pl. 24, fig. } 4 \\
=\text { Leepierceia preartocarpoides (R. W. BROWN) } \\
\text { K. JOHNSON) }\end{array}$ \\
\hline Incertae Sedis & Wardiaphyllum daturaefolium (WARD) HICKEY & Credneria? daturaefolia $\mathrm{WARD}$ \\
\hline Incertae Sedis & Cissites panduratus KNOWLTON (according to Wolfe and Tanai 1987) & Acer fragilis KNOWLTON \\
\hline Incertae Sedis & Calycites polysepala NEWBERRY & Calycites polysepala NEWBERRY \\
\hline Incertae sedis & "Juglans" berryana (KNOWLTON) R. W. BROWN & Juglans berryana (KNOWLTON) R. W. BROWN \\
\hline Incertae Sedis & “Juglans" taurina R. W. BROWN ex WATT & Juglans taurina R. W. BROWN ex WATT \\
\hline Incertae Sedis & "Salix" aquilina R. W. BROWN ex WATT & Salix aquilina R. W. BROWN ex WATT \\
\hline Incertae Sedis & "Ficus" minutidens KNOWLTON & Ficus minutidens KNOWLTON \\
\hline Incertae Sedis & "Ficus" planicostata LESQUEREUX & Ficus planicostata LESQUEREUX \\
\hline Incertae Sedis & "Ficus" subtruncata LESQUEREUX & Ficus subtruncata LESQUEREUX \\
\hline Incertae Sedis & "Ficus" uncata LESQUEREUX & Ficus uncata LESQUEREUX \\
\hline Incertae Sedis & "Morus" montanensis R. W. BROWN & Morus montanensis R. W. BROWN \\
\hline Incertae Sedis & "Asimina" vesperalis $\mathrm{R}$. W. BROWN & Asimina vesperalis $\mathrm{R}$. W. BROWN \\
\hline Incertae Sedis & "Celtis" newberryi KNOWLTON et COCKERELL & Celtis newberryi KNOWLTON et COCKERELL \\
\hline
\end{tabular}




\begin{tabular}{|c|c|c|}
\hline Phylogenetic position & Current assignment & Old name from Brown (1962) \\
\hline Incertae Sedis & "Celtis" peracuminata $\mathrm{R}$. W. BRowN & Celtis peracuminata $\mathrm{R}$. W. BROWN \\
\hline Incertae Sedis & "Ficus" affinis (LESQUEREUX) R. W. BROWN & Ficus affinis (LESQUEREUX) R. W. BROWN \\
\hline Incertae Sedis & "Hydrangea" antica R. W. BROWN ex WATT & Hydrangea antica R. W. BROWN ex WATT \\
\hline Incertae Sedis & "Magnolia" borealis R. W. BROWN & Magnolia borealis R. W. BROWN \\
\hline Incertae Sedis & "Magnolia" berryi (KNOWLTON) R. W. BROWN & Magnolia berryi (KNOWLTON) R. W. BROWN \\
\hline Incertae Sedis & "Magnolia" magnifolia KNOWLTON & Magnolia magnifolia KNOWLTON \\
\hline Incertae Sedis & "Magnolia" rotundifolia NEWBERRY & Magnolia rotundifolia Newberry \\
\hline Incertae Sedis & "Rhamnus" geowandrewsii WATT (1975) & $\begin{array}{l}\text { Rhammus hirsuta R. W. BROWN ex WATT. (Non Rhammus } \\
\text { hirsuta WIGHT and ARNOTT 1834) }\end{array}$ \\
\hline Incertae Sedis & "Nyssa" alata (WARD) R. W. BROWN & Nyssa alata (WARD) R. W. BROWN \\
\hline Incertae Sedis & "Nyssa" borealis R. W. BROWN & Nyssa borealis R. W. BROWN \\
\hline Incertae Sedis & "Nyssa?" obovata KNOWLTON & Nyssa? obovata KNOWLTON \\
\hline Incertae Sedis & "Apocynophyllum” lesquereuxi ETTINGSHAUSEN & Apocynophyllum lesquereuxii ETTINGSHAUSEN \\
\hline Incertae Sedis & "Cercocarpus" ravenscragensis BERRY & Cercocarpus ravenscragensis BERRY \\
\hline Incertae Sedis & "Fraxinus" eocenica LESQUEREUX & Fraxinus eocenica LESQUEREUX \\
\hline Incertae Sedis & "Magnolia" berryi (KNOWLTON) R. W. BROWN & Magnolia berryi (KNOWLTON) R. W. BROWN \\
\hline Incertae Sedis & "Ilex" artocarpidioides (LESQUEREUX) R. W. BROWN ex WATT & Ilex artocarpidioides (LESQUEREUX) R. W. BROWN ex WATT \\
\hline Incertae Sedis & "Viburnum" solitarium LESQUEREUX & $\begin{array}{l}\text { Viburnum solitarium LESQUEREUX (Brown 1962, pl. 67, } \\
\text { figs } 33,34 \text { ) }\end{array}$ \\
\hline Incertae Sedis & "Staphylea" minutidens (KNOWLTON) R. W. BROWN & Staphylea minutidens (KNOwLTON) R. W. BROWN \\
\hline Incertae Sedis & Cissites rocklandensis $\mathrm{R}$. W. BROWN & Cissites rocklandensis $\mathrm{R}$. W. BROWN \\
\hline Incertae Sedis & "Dillenites" garfieldensis R. W. BROWN ex WATT & Dillenites garfieldensis R. W. BROWN ex WATT \\
\hline Incertae Sedis & "Parthenocissus" ursina R. W. BROWN ex WATT & Parthenocissus ursina R. W. BROWN ex WATT \\
\hline Incertae Sedis & "Dombeyopsis" magnifica KNOWLTON & Dombeyopsis magnifica KNOWLTON \\
\hline
\end{tabular}

Table 2. Taxonomic determinations Brown 1962, in sequence as he presented them, followed by current name and comments. Numbers in left column indicate the species listed by locality in column 5 of Appendix Table 1. "Pl.", and "fig." refer to specific plates and figures of Brown (1962).

\begin{tabular}{|c|c|c|}
\hline & Name applied by Brown (1962) & Current name, comments \\
\hline 1 & Marchantia lignitica (WARD) R. W. BROWN & accepted; thallus with similar areolation to extant genus \\
\hline 2 & Marchantia pealei KNOWLTON & uncontested; thallus lacks areolation. [liverwort] \\
\hline 3 & Preissites wardii KNOWLTON & uncontested \\
\hline 4 & Hypnum coloradense R. W. BROWN & questionable genus [moss] \\
\hline 5 & Mnium montanense R. W. BRowN & questionable genus [moss] \\
\hline 6 & Hymenophyllum confusum LESQUEREUX & questionable; poorly preserved [fern] \\
\hline 7 & Allantodiopsis erosa (LESQUEREUX) KNOWLTON et MAXON & $\begin{array}{l}\text { uncontested, but some specimens may represent the cycad, } \\
\text { Eostangeria pseudopteris }\end{array}$ \\
\hline 8 & Blechnum anceps (LEQSUEREUX) R. W. BROWN & questionable; no fertile material available [fern] \\
\hline 9 & Dennstaedtia americana KNOWLTON & $\begin{array}{l}\text { Kvaček and Manum (1993: 173, tab. 3) suggested should be transferred } \\
\text { to the extinct genus Coniopteris of the Dicksoniaceae [fern] }\end{array}$ \\
\hline 10 & Dryopteris lakesii (LESQUEREUX) KNOWLTON & questionable generic assignment (Collinson 1991) [fern] \\
\hline 11 & Dryopteris meeteetseana R. W. BROWN & questionable \\
\hline 12 & Dryopteris serrata $\mathrm{R} . \mathrm{W}$. BROWN & questionable “ \\
\hline 13 & Lastrea goldiana (LESQUEREUX) LESQUEREUX & questionable \\
\hline 14 & Onoclea hesperia $\mathrm{R}$. W. BROWN & $\begin{array}{l}\text { see argument for placement in extant species, O. sensibilis } \\
\text { (Rothwell and Stockey 1991) [Onocleaceae] }\end{array}$ \\
\hline 15 & Saccoloma gardneri (LESQUEREUX) KNOWLTON & $\begin{array}{l}\text { Dennastra sorimarginata MCIVER et BASINGER. } \\
\text { [Probably Dennstaedtiaceae (Collinson 2001)]. }\end{array}$ \\
\hline 16 & Woodwardia arctica (HEER) R. W. BROWN & $\begin{array}{l}\text { Woodwardia gravida HICKEY. Another species, W. maxoni KNOWLTON, } \\
\text { was included in synonymy by Brown (1962), but considered distinct } \\
\text { by McIver and Basinger; (1993); (Collinson 2001) [Blechnaceae] }\end{array}$ \\
\hline 17 & Gleichenia hesperia R. W. BROWN ex WATT & Questionable generic placement (Brown 1962) [fern] \\
\hline 18 & Anemia elongata (NEWBERRY) KNOWLTON & Anemia-like sterile foliage (Collinson 2001) [Schizaeaceae] \\
\hline 19 & Lygodium coloradense KNOWLTON & OK [Schizaeaceae] \\
\hline 20 & Osmunda greenlandica $\cdot($ HeER) R. W. BROWN & $\begin{array}{l}\text { Tidwell and Parker (1987) described permineralized osmundaceous stem } \\
\text { remains associated with pinnules of } O \text {. greenlandica. [Osmundaceae] }\end{array}$ \\
\hline 21 & Osmunda macrophylla PENHALLOW & OK [Osmundaceae] \\
\hline 22 & Equisetum spp. & OK [Equisetaceae] \\
\hline 23 & Isoetites horridus (DAWSON) R. W. BROWN & $\begin{array}{l}\text { OK Hickey (1977) recovered in situ megaspores similar to the } \\
\text { dispersed spores of Minerosporites dissimilis [Isoetaceae] }\end{array}$ \\
\hline 24 & Selaginella berthoudii LESQUEREUX & uncontested [Sellaginellaceae] \\
\hline 25 & Selaginella collieri KNOWLTON & uncontested [Sellaginellaceae] \\
\hline 26 & Selaginella monstrosa (HOLLICK) R. W. BROWN & uncontested [Sellaginellaceae] \\
\hline
\end{tabular}




\begin{tabular}{|c|c|c|}
\hline & Name applied by Brown (1962) & Current name, comments \\
\hline 27 & Zamia coloradensis (KNOWLTON) R. W. BROWN & $\begin{array}{l}\text { lacks well preserved cuticle so it cannot be confirmed whether } \\
\text { it represents Zamia, or another, perhaps extinct genus [cycad] }\end{array}$ \\
\hline 28 & Zamia wyomingensis $\mathrm{R}$. W. BROWN & $\begin{array}{l}\text { lacks well preserved cuticle so it cannot be confirmed whether } \\
\text { it represents Zamia, or another, perhaps extinct, genus [cycad] }\end{array}$ \\
\hline 29 & Ginkgo adiantoides (UNGER) HEER & $\begin{array}{l}\text { reassigned to Ginkgo cranei ZHOU, QUAN ET LIU based on associated } \\
\text { reproductive structures [Ginkgoaceae] }\end{array}$ \\
\hline 30 & Amentotaxus campbellii (GARDNER) FLORIN & $\begin{array}{l}\text { Amentotaxus gladifolia (LUDWIG) FERGUSON, JÄHNICHEN et ALVIN } \\
\text { (Jähnichen 1990) [Amentotaxaceae] }\end{array}$ \\
\hline 31 & Araucaria longifolia (LESQUEREUX) R. W. BROWN & unchallenged, but in need of closer investigation \\
\hline 32 & Glyptostrobus nordenskioldii (HEER) R. W. BROWN & $\begin{array}{l}\text { Glyptostrobus europaeus (BRONGNIART) HEER according to Hickey } \\
\text { (1977); authority corrected as G. europaeus (BRONGNIART) UNGER } \\
\text { (LePage 2007) [Cupressaceae] }\end{array}$ \\
\hline 33 & Metasequoia occidentalis (NEWBERRY) CHANEY & $\begin{array}{l}\text { partially overlapping with Paleocene Metasequoia foxii STOCKEY, } \\
\text { RoTHWELL et FALDER [Cupressaceae] }\end{array}$ \\
\hline 34 & Taxodium olrikii (HEER) R. W. BROWN & $\begin{array}{l}\text { genus unconfirmed due to lack of convincing reproductive material } \\
\text { [Cupressaceae] }\end{array}$ \\
\hline 35 & Fokienia catenulata (BELL) R. W. BROWN & $\begin{array}{l}\text { Ditaxocladus catenulatus (W.A. BELL) S.X. GuO, Z. KVAČEK, } \\
\text { MANCHESTER et Z.K. ZHOU [Cupressaceae] }\end{array}$ \\
\hline 36 & Thuja interrupta NEWBERRY & $\begin{array}{l}\text { Mesocyparis borealis McIvER et Basinger (same kind of foliage, } \\
\text { with attached cones) [Cupressaceae] }\end{array}$ \\
\hline 37 & Sparganium antiquum (NEWBERRY) BERRY & $\begin{array}{l}\text { Not Sparganium, rather it is an infructescence of Macginicarpa } \\
\text { [Platanaceae] }\end{array}$ \\
\hline 38 & Alismaphyllites grandifolius (PENHALLOW) R. W. BROWN & $\begin{array}{l}\text { illustrated specimens of Brown (1962) were reassigned to } \\
\text { Haemanthophyllum sp. } 3 \text { (Golovneva 1997) }\end{array}$ \\
\hline 39 & Sagittaria megasperma R. W. BROWN ex WATT & $\begin{array}{l}\text { rejected; well preserved globose infructescence containing winged } \\
\text { fruits of uncertain affinities. Reillustrated here, text-fig. } 3.1-3.3\end{array}$ \\
\hline 40 & Hydromystria expansa (HEER) HANTKE & $\begin{array}{l}\text { leaves of Limnobiophyllum scutatum (DAWSON) KRASSILOV (1973) } \\
\text { [Araceae] + unrelated fruits of LESQUERUEX) HICKEY emend. } \\
\text { MANCHESTER et KODRUL [40a in Appendix Table 1] }\end{array}$ \\
\hline 41 & Grasslike monocotyledons & uncertain [monocot] \\
\hline 42 & Chamaedorea danae (LESQUEREUX) BERRY & affinity to Chamaedorea unconfirmed. [palm] \\
\hline 43 & Paloreodoxites plicatus (LESQUEREUX) KNOWLTON & accepted by Read and Hickey (1972) [palm] \\
\hline 44 & Thrinax dorfii $\mathrm{R}$. W. BROWN & Palmacites dorfii (R.W. BROWN) READ et HICKEY [palm] \\
\hline 45 & Sabal grayana LESQUEREUX & Sabalites grayana (LESQUEREUX) KNOWLTON [palm] \\
\hline 46 & Sabal imperialis DAWSON & uncontested [palm] \\
\hline 47 & Sabal powellii NEWBERRY & $\begin{array}{l}\text { Sabalites powellii (NEWBERRY) BERRY sensu Read and Hickey. } \\
\text { (holotype is from Eocene Green River Fm) [palm] }\end{array}$ \\
\hline 48 & Canna? magnifolia KNOWLTON & $\begin{array}{l}\text { Specimen figured by Brown (pl. 15, fig. 2) was transferred to } \\
\text { Zingiberopsis isonervosa HICKEY by Hickey and Petersen (1978) } \\
\text { [Zingiberales] }\end{array}$ \\
\hline 49 & Zingiberites dubius LESQUEREUX & uncontested [Zingiberales] \\
\hline 50 & Salix aquilina $\mathrm{R}$. W. BROWN ex WATT & "referred to Salix with some hesitation" (Brown 1962) [dicot] \\
\hline 51 & Carya antiquorum NEWBERRY & $\begin{array}{l}\text { original leaflets of Newberry remain as C. antiquorum [Juglandaceae], } \\
\text { but most leaflets figured by Brown (1962) are Aesculus hickeyi } \\
\text { MANCHESTER [Sapindaceae] }\end{array}$ \\
\hline 52 & Juglandicarya spp. & Juglandicarya simplicarpa MANCHESTER \\
\hline 53 & Juglans berryana (KNOWLTON) R. W. BROWN & questionable generic assignment \\
\hline 54 & Juglans taurina $\mathrm{R}$. W. BROWN ex WATT & questionable generic assignment \\
\hline 55 & Pterocarya glabra R. W. BROWN ex WATT & $\begin{array}{l}\text { Polyptera manningii MANCHESTER et DILCHER (fruits), Juglandiphyllites } \\
\text { glabra (R. W. BROWN ex WATT) MANCHESTER et DILCHER (leaves) }\end{array}$ \\
\hline 56 & Pterocarya hispida $\mathrm{R}$. W. BROWn ex WATT & $\begin{array}{l}\text { Cyclocarya brownii MANCHESTER et DILCHER (fruits), Cyclocarya } \\
\text { hispida (R. W. BROWN) comb. nov. (leaves) }\end{array}$ \\
\hline 57 & Betula stevensonii LESQUEREUX & perhaps Betulaceae, but probably not Betula \\
\hline 58 & Corylus insignis HEER & Craspedodromophyllum malmgrenii (HEER) GOLOVNEVA [Betulaceae] \\
\hline 59 & Castanea intermedia LESQUEREUX & $\begin{array}{l}\text { uncontested, although no reproductive structures of this genus have } \\
\text { been recovered }\end{array}$ \\
\hline 60 & Quercus asymmetrica TRELEASE & $\begin{array}{l}\text { uncontested, although no reproductive structures of this genus have } \\
\text { been recovered }\end{array}$ \\
\hline 61 & Quercus greenlandica HEER & Fagopsiphyllum groenlandicum (HEER) MANCHESTER 1999 [Fagaceae?] \\
\hline 62 & Quercus macneilii R. W. BROWN & no reproductive structures of this genus have been recovered \\
\hline 63 & Quercus sullyi NEWBERRY & $\begin{array}{l}\text { Most specimens that Brown illustrated appear to be Dyrana flexuosa } \\
\text { (NEWBERRY) GolovNEVA }\end{array}$ \\
\hline 64 & Quercus yulensis R. W. BROWN & possibly corresponding to Fagopsiphyllum \\
\hline 65 & Celtis newberryi KNOWLTON et COCKERELL & genus unconfirmed [dicot] \\
\hline 66 & Celtis peracuminata $\mathrm{R}$. W. BROWN & genus unconfirmed [dicot] \\
\hline
\end{tabular}




\begin{tabular}{|c|c|c|}
\hline & Name applied by Brown (1962) & Current name, comments \\
\hline 67 & Planera microphylla NEWBERRY & Ulmites microphylla (NEWBERRY) comb n. [Ulmaceae] \\
\hline 68 & Ulmus rhamnifolia WARD & $\begin{array}{l}\text { Fruits attributed to this species by Brown were later identified as } \\
\text { Polygonocarpum curtisii MANCHESTER et O'LEARY (Brown 1962, pl. 24, } \\
\text { fig. 17) and Podopterus antiqua MANCHESTER et O'LEARY (Brown 1962, } \\
\text { pl. 24, fig. 18) [Polygonaceae]. Leaves are Ulmites microphylla } \\
\text { (NEWBERRY) comb. nov. [Ulmaceae] }\end{array}$ \\
\hline 69 & Zelkova planeroides (WARD) R. W. BROWN & Ulmites microphylla (NEWBERRY) comb. nov. [Ulmaceae] \\
\hline 70 & "Artocarpus" lessigiana (LESQUEREUX) KNOWLTON & $\begin{array}{l}\text { extinct genus of probable lauraceous affinity (Kirk Johnson pers. } \\
\text { comm.) }\end{array}$ \\
\hline 71 & Ficus affinis (LESQUEREUX) R. W. BROWN & generic and familial assignment rejected \\
\hline 72 & Ficus artocarpoides LESQUEREUX & $\begin{array}{l}\text { genus rejected; not likely Moraceae; among specimens figured by } \\
\text { Brown most are Mciveraephyllum nebrascense (SCHIMPER) comb. } \\
\text { nov., but one (pl. 24, fig. 4) is Leepierceia preartocarpoides } \\
\text { (R. W. BROWN) K. JOHNSON }\end{array}$ \\
\hline 73 & Ficus minutidens KNOWLTON & generic and familial assignment rejected \\
\hline 74 & Ficus planicostata LESQUEREUX & generic and familial assignment rejected \\
\hline 75 & Ficus subtruncata LESQUEREUX & generic and familial assignment rejected \\
\hline 76 & Ficus uncata LESQUEREUX & generic and familial assignment rejected \\
\hline 77 & Morus montanensis R. W. BROWN & generic assignment rejected; lacks occasional lobation of Morus \\
\hline 78 & Platanus nobilis NEWBERRY & $\begin{array}{l}\text { Macginitiea nobilis (NEWBERRY) comb. nov. (3-lobed laminae) } \\
\text { + Macginitiea gracilis (LESQUEREUX) J. WOLFE et WEHR } \\
\text { (5-lobed laminae) [Platanaceae] }\end{array}$ \\
\hline 79 & Platanus raynoldsii NEWBERRY & Platanites raynoldsii (NEWBERRY) comb. nov. [Platanaceae] \\
\hline 80 & Credneria? daturaefolia WARD & Wardiaphyllum daturaefolium (WARD) HICKEY [Family unknown] \\
\hline 81 & Cinnamomum sezannense WATELET & familial assignment $\mathrm{OK}$, generic assignment questionable \\
\hline 82 & Laurophyllum caudatum (KNOWLTON) R. W. BROWN & OK \\
\hline 83 & Laurophyllum perseanum $\mathrm{R}$. W. BROWN ex WATT & OK \\
\hline 84 & Laurus socialis LESQUEREUX & "Laurus" socialis LESQUEREUX \\
\hline 85 & Lindera obtusata (WARD) R. W. BROWN & "Lindera" obtusata (WARD) R. W. BROWN \\
\hline 86 & Persea brossiana LESQUEREUX & "Persea" brossiana LESQUEREUX \\
\hline 87 & Sassafras thermale (LESQUEREUX) R. W. BROWN & $\begin{array}{l}\text { "Sassafras" thermale (LESQUEREUX) R. W. BROWN; illustrated } \\
\text { specimens of Brown are not lobed. Suprabasal acrodromy is OK } \\
\text { for Lauraceae. No cuticle. }\end{array}$ \\
\hline 88 & Cabomba inermis (NEWBERRY) HOLLICK & cf. roots of Quereuxia. \\
\hline 89 & Nelumbium montanum R. W. BROWN & $\begin{array}{l}\text { Nelumbago montanum (R. W. BROWN ex WATT) MCIVER et BASINGER } \\
\text { peltate leaves and fruit similar to Nelumbo [Nelumbonaceae] }\end{array}$ \\
\hline 90 & Nelumbium tenuifolium LESQUEREUX & uncontested \\
\hline 91 & Nymphaea leei (KNOWLTON) R. W. BROWN & uncontested \\
\hline 92 & Nymphaea pulchella (KNOWLTON) R. W. BROWN & accepted [Nymphaeaceae] \\
\hline 93 & Paleonelumbo macroloba KNOWLTON & accepted [Nelumbonaceae] \\
\hline 94 & Paleonuphar.hesperium R. W. BROWN & resembles extant Nuphar [Nymphaeaceae] \\
\hline 95 & Paranymphaea crassifolia (NEWBERRY) BERRY & Polygonaceae according to McIver and Basinger (1993) \\
\hline 96 & Cercidiphyllum arcticum (HEER) R. W. BROWN & $\begin{array}{l}\text { Heterogeneous taxon: leaves of Trochodendroides genetrix } \\
\text { (NEWBERRY) comb. nov. and Zizyphoides flabellum (NEWBERRY) } \\
\text { CRANE, MANCHESTER et DILCHER; plus fruits of Nyssidium, } \\
\text { and Nordenskioeldia }\end{array}$ \\
\hline 97 & Magnolia berryi (KNOWLTON) R. W. BROWN & "Magnolia" berryi (KNOWLTON) R. W. BROWN \\
\hline 98 & Magnolia borealis R. W. BROWN & "Magnolia" borealis R. W. BROWN \\
\hline 99 & Magnolia magnifolia KNOWLTON & "Magnolia" magnifolia KNOWLTON \\
\hline 100 & Magnolia regalis HEER & "Magnolia" regalis HEER \\
\hline 101 & Magnolia rotundifolia NEWBERRY & "Magnolia" rotundifolia NEWBERRY \\
\hline 102 & Hamamelites inaequalis (NEWBERRY) R. W. BROWN & possibly Hamamelidaceae \\
\hline 103 & Liquidambar dakotense R. W. BROWN ex WATT & $\begin{array}{l}\text { Not Liquidambar; probably the winged seed of Nyssidium arcticum } \\
\text { (HEER) ILJINSKAYA }\end{array}$ \\
\hline 104 & Eucommia serrata (NEWBERRY) R. W. BROWN & Browniea serrata (NEWBERRY) MANCHESTER et HICKEY [Nyssaceae] \\
\hline 105 & Hydrangea antica R. W. BROWN ex WATT & "Hydrangea" antica R. W. BROWN ex Watt \\
\hline 106 & Asimina vesperalis $\mathrm{R}$. W. BROWN & "Asimina" vesperalis R. W. BROWN \\
\hline 107 & Cercocarpus ravenscragensis BERRY & "Cercocarpus" ravenscragensis BERRY \\
\hline 108 & Prunus careyhurstia R. W. BROWN ex WaTT & "Prunus" careyhurstia R. W. BROWN ex WaTT \\
\hline 109 & Prunus coloradensis KNOWLTON & "Prunus" coloradensis KNOWLTON \\
\hline 110 & Prunus corrugis $\mathrm{R}$. W. BROWN ex WATT & $\begin{array}{l}\text { Icacinicaryites corruga (R. W. BROWN) PIGG, MANCHESTER et DEVORE } \\
\text { (large fruit) and Icacinicaryites linchensis PIGG, MANCHESTER } \\
\text { et DEVORE (smaller fruits) }\end{array}$ \\
\hline 111 & "Prunus" mclearni BERRY & Prunites maclearnii (BERRY) MCIVER et BASINGER \\
\hline 112 & Prunus perita R. W. BROWN ex WATT & "Prunus" perita R. W. BROWN ex WATT \\
\hline
\end{tabular}




\begin{tabular}{|c|c|c|}
\hline & Name applied by Brown (1962) & Current name, comments \\
\hline 113 & Bauhinia wyomingana R. W. BROWN & $\begin{array}{l}\text { "Bauhinia" wyomingana R. W. BROwn Not Bauhinia. Magnoliaceae, } \\
\text { cf. Liriodendron. }\end{array}$ \\
\hline 114 & Leguminosites coloradensis KNOWLTON & $\begin{array}{l}\text { Brown (1962) was not sure if this represents Leguminosae or another } \\
\text { family such as Bignoniaceae. }\end{array}$ \\
\hline 115 & Mimosites coloradensis KNOWLTON [Coalmont Fm] & not restudied. \\
\hline 116 & Robinia wardii (KNOWLTON) R. W. BROWN & $\begin{array}{l}\text { Leguminosae. These pods differ from the type material of Robinia } \\
\text { wardii,and therefore require a different specific epithet. Clearly } \\
\text { Leguminosae but not Robinia (Herendeen pers. comm. 2013) }\end{array}$ \\
\hline 117 & Staphylea minutidens (KNOWLTON) R. W. BROWN & "Staphylea" minutidens (KNOWLTON) BRown \\
\hline 118 & Acer fragilis KNOWLTON & Cissites panduratus KNOWLTON (according to Wolfe and Tanai 1987) \\
\hline 119 & Acer newberryi R. W. BROWN & Dicotylophyllum triloba (NEWBERRY) J. WOLFE et TANAI 1987 \\
\hline 120 & Acer silberlingii R. W. BROWN & Dicotylophyllum silberlingi (R. W. BROWN) J. WOLFE et TANAI 1987 \\
\hline 121 & Acer spp. & $\begin{array}{l}\text { some of the fruits represent typical schizocarpic samaras of Acer; } \\
\text { others are nonschizocarpic, representing the extinct genus Deviacer } \\
\text { MANCHESTER }\end{array}$ \\
\hline 122 & Sapindus affinis (NEWBERRY) R. W. BROWN & Averrhoites affinis (NEWBERRY) HICKEY \\
\hline 123 & Koelreuteria annosa $\mathrm{R}$. W. BROWN & Not Koelreuteria. [?Rutaceae ] \\
\hline 124 & Ilex artocarpidioides (LESQUEREUX) R. W. BROWN ex WATT & "Ilex" artocarpidioides (LESQUEREUX) R. W. BROWN ex WATT \\
\hline 125 & Paliurus? sp. & Not rexamined. Published figure is a line drawing. \\
\hline 126 & Rhamnus cleburnii LESQUEREUX & Rhamnites cleburnii (LESQUEREUX) McIVER et BASINGER \\
\hline 127 & Rhatmus goldiana LESQUEREUX & Rhamnus goldiana LESQUEREUX \\
\hline 128 & $\begin{array}{l}\text { Rhammus hirsuta R. W. BRown ex WATT. (Non Rhamnus hirsuta } \\
\text { Wight et ARNOTt 1834) }\end{array}$ & $\begin{array}{l}\text { "Rhamnus" geowandrewsii WATT (1975) [probably not Rhamnus } \\
\text { or Rhamnaceae, however] }\end{array}$ \\
\hline 129 & Zizyphus fibrillosus (LESQUEREUX) LESQUEREUX & "Zizyphus" fibrillosus (LESQUEREUX) LESQUEREUX \\
\hline 130 & Zyzyphoides mackayi BELL & not restudied \\
\hline 131 & Ampelopsis acerifolia (NEWBERRY) R. W. BROWN & $\begin{array}{l}\text { Archeampelos acerifolia (NEWBERRY) MCLVER et BASINGER (1993). } \\
\text { [Cercidiphyllaceae?] }\end{array}$ \\
\hline 132 & Cissus marginata (LESQUEREUX) R. W. BROWN & Platanites marginata (LESQUEREUX) K. JOHNSON [Platanaceae] \\
\hline 133 & Cissites rocklandensis $\mathrm{R}$. W. BROWN & uncertain familial affinity \\
\hline 134 & Parthenocissus ursina $\mathrm{R}$. W. BROWN ex WATT & "Parthenocissus" ursina R. W. BROWN ex WATT [uncertain family] \\
\hline 135 & Vitis lobata (KNOWLTON) R. W. BROWN & Cucurbitaciphyllum lobatum (KNOWLTON) comb. nov. [Cucurbitaceae] \\
\hline 136 & Vitis olrikii HEER & Dicotylophyllum hansonium PEPPE et HICKEY (2014) [uncertain family] \\
\hline 137 & Vitis sp. & $\begin{array}{l}\text { seed characteristic of Vitaceae. It likely belongs either to Vitis } \\
\text { or Ampelocissus. }\end{array}$ \\
\hline 138 & Dombeyopsis magnifica KNOWLTON & Dombeyopsis magnifica KNOWLTON \\
\hline 139 & Pterospermites cordatus WARD & Penosphyllum cordatum (WARD) HICKEY 1977 [Malvaceae sl.] \\
\hline 140 & Dillenites garfieldensis R. W. BROWN ex WATT & Dillenites garfieldensis R. W. BROWN ex WATT [uncertain family] \\
\hline 141 & Myrtophyllum torreyi (LESQUEREUX) DORF & $\begin{array}{l}\text { rejected from Myrtaceae because the leaves are serrate; probably } \\
\text { Chloranthaceae (Upchurch and Dilcher 1990) }\end{array}$ \\
\hline 142 & Trapa angulata (NEWBERRY) R. W. BROWN & $\begin{array}{l}\text { Quereuxia angulata (NEWBERRY) KRYSHTOFOVICH (see Hickey } 2001 \\
\text { for nomenclature review). [uncertain family] }\end{array}$ \\
\hline 143 & Trapa paulula (BELL) R. W. BROWN & Quereuxia angulata (NEWBERRY) KRYSHTOFOVICH [uncertain family] \\
\hline 144 & Melastomites montanensis R. W. BROWN ex WATT & Likely to be leaves of Lauraceae. \\
\hline 145 & Cornus hyperborea HEER & $\begin{array}{l}\text { Possibly Cornus swingii MANCHESTER, XIANG, KODRUL et AKHMETIEV } \\
\text { but lacking the diagnostic trichomes [Cornaceae?] }\end{array}$ \\
\hline 146 & $\begin{array}{l}\text { Cornus nebrascensis SCHIMPER (nontype specimens figured } \\
\text { under this name by Brown) }\end{array}$ & Cornus swingii MANCHESTER, XIANG, KodRUL et AKHMETIEV \\
\hline 147 & Nyssa alata (WARD) R. W. BROWN & "Nyssa" alata (WARD) R. W. BROWN \\
\hline 148 & Nyssa borealis R. W. BRown & "Nyssa" borealis R. W. BROWN \\
\hline 149 & Nyssa? obovata KNOWLTON & "Nyssa"? obovata KNOWLTON \\
\hline 150 & Kalmia elliptica R. W. BROWN & $\begin{array}{l}\text { "Kalmia" elliptica R. W. BROWN (entire-margined leaves; family } \\
\text { and genus uncertain in my opinion) }\end{array}$ \\
\hline 151 & Fraxinus eocenica LESQUEREUX & "Fraxinus" eocenica LESQUEREUX \\
\hline 152 & Apocynophyllum lesquereuxii ETTINGSHAUSEN & Apocynophyllum lesquereuxii ETTINGSHAUSEN [uncertain family] \\
\hline 153 & Viburnum asperum (NEWBERRY) R. W. BROWN & $\begin{array}{l}\text { Celtis asperum (NEWBERRY) MANCHESTER, AKHMETIEV et KODRUL } \\
\text { [Cannabaceae] }\end{array}$ \\
\hline 154 & Viburnum cupanioides (NEWBERRY) R. W. BROWN & $\begin{array}{l}\text { Beringiaphyllum cupanioides (NEWBERRY) MANCHESTER, CRANE } \\
\text { et GOLOVNEVA [Nyssaceae] }\end{array}$ \\
\hline 155 & Viburnum tilioides WARD & Davidia antiqua (NEWBERRY) MANCHESTER (fruits) [Nyssaceae] \\
\hline 156 & Viburnum antiquum (NEWBERRY) HOLLICK & Davidia antiqua (NEWBERRY) MANCHESTER (leaves) [Nyssaceae] \\
\hline 157 & Phyllites demoresi $\mathrm{R}$. W. BROWN & Phyllites demoresii $\mathrm{R}$. W. BROWN \\
\hline 158 & Phyllites disturbans R. W. BROWN & Phyllites disturbans $\mathrm{R}$. W. BROWN \\
\hline 159 & Phyllites pagosensis R. W. BROWN & Phyllites pagosensis R. W. BROWN \\
\hline 160 & "Leaf with minute teeth" & not restudied \\
\hline 161 & Calycites hexaphylla LESQUEREUX & Calycites hexaphylla LESQUEREUX \\
\hline
\end{tabular}




\begin{tabular}{|c|c|c|}
\hline & Name applied by Brown (1962) & Current name, comments \\
\hline 162 & Calycites polysepala NEWBERRY & Calycites polysepala NEWBERRY \\
\hline 163 & Carpolithes spinosus NEWBERRY & Sloanea ungeri (HEER) MANCHESTER et Z. KVAČEK [Elaeocarpaceae] \\
\hline 164 & Nordenskioldia borealis HEER & $\begin{array}{l}\text { Nordenskioeldia borealis HEER [note corrected spelling] } \\
\text { [Trochodendraceae] }\end{array}$ \\
\hline 165 & Palmocarpon commune LESQUEREUX & Not restudied \\
\hline 166 & Palmocarpon compositum LESQUEREUX & Not restudied \\
\hline 167 & Palmocarpon lineatum LESQUEREUX & Not restudied \\
\hline 168 & Palmocarpon subcylindricum LESQUEREUX & Not restudied \\
\hline 169 & Palmocarpon truncatum LESQUEREUX & Not restudied \\
\hline 170 & Viburnum goldianum LESQUEREUX & $\begin{array}{l}\text { Seeds of Zingiberales. Ensete goldianum (LESQUEREUX) comb. nov. } \\
\text { Reillustrated here, text-fig. 3.4, 3.5. }\end{array}$ \\
\hline 171 & Viburnum solitarum LESQUEREUX & "Viburnum" solitarum LESQUEREUX \\
\hline 172 & Carpites rostellatus LESQUEREUX & $\begin{array}{l}\text { Meliosma rostellata (LESQUEREUX) CRANE, MANCHESTER et DILCHER } \\
\text { [Sabiaceae] }\end{array}$ \\
\hline 173 & "Five-loculed fruit" (pl. 67, fig. 5) & Incertae sedis \\
\hline 174 & $\begin{array}{l}\text { "Maplelike samaras, but probably of sapindaceous affinity" } \\
\text { (pl. } 67 \text {, fig. } 6,7)\end{array}$ & Deviacer wolfei MANCHESTER [uncertain family] \\
\hline 175 & $\begin{array}{l}\text { "Seeds with papillose inner surface" } \\
\text { (pl. } 67 \text {, figs } 9,10,14-16,20,22,23 \text { ) }\end{array}$ & Nordenskioeldia borealis dispersed seeds. [Trochodendraceae] \\
\hline 176 & "Flattened, carbonized fruit with scars" (pl. 67, fig. 10) & Incertae sedis. \\
\hline 177 & "Probably fruits with remnants of calyces" (pl. 67, fig. 11, 12, 17): & $\begin{array}{l}\text { Fruit of Browniea serrata (NEWBERRY) MANCHESTER et HICKEY } \\
\text { [Nyssaceae] }\end{array}$ \\
\hline 178 & Nordenskioeldia borealis HEER (pl. 67, fig. 13, 45) & Nordenskioeldia borealis HEER [Trochodendraceae; Crane et al. 1991] \\
\hline 179 & "Spike or catkin of seeds" (pl. 67, fig. 21) & Interesting, well preserved, in need of detailed study \\
\hline 180 & $\begin{array}{l}\text { Impression of a seed showing pits arranged in longitudinal rows } \\
\text { (pl. 67, fig. 26) }\end{array}$ & Palaeophytocrene piggae STULL (Stull et al. 2012) \\
\hline 181 & Seeds with ridges and scattered glands (pl. 67, fig. 28,29 ) & Indet. \\
\hline 182 & Heart-shaped fruits or seeds (pl. 67, fig. 32) & Indet. \\
\hline 183 & Viburnum solitarium LESQUEREUX (pl. 67, fig. 33, 34) & Indet. \\
\hline 184 & "Elliptic fruit with a fringe of hairs or filaments" pl. 67, fig. 35) & Sloanea ungeri (HEER) MANCHESTER et Z. KVAČEK \\
\hline 185 & Oval fruit with several locules (pl. 67, fig. 36) & Indet. \\
\hline 186 & $\begin{array}{l}\text { Oval seeds like figs } 33 \text { and } 34 \text { but rounded at the top, not squarish } \\
\text { (pl. 67, fig. 38) }\end{array}$ & Indet. \\
\hline 187 & Burlike objects (pl. 67, fig. 39-42, 47) & Palaeocarpinus joffrense Sun et STOCKEY fruits [Betulaceae] \\
\hline 188 & Probably the fertile cone of an Equisetum (pl. 67, fig. 43) & Equisetum strobilus \\
\hline 189 & Longitudinal hollow studded with bilobed projections (pl. 67, fig.44) & Hamamelidaceae raceme \\
\hline 190 & Calyx of a flower (pl. 67, fig. 46) & Perianth of a Browniea fruit [Nyssaceae] \\
\hline 191 & Roots with rootlets (pl. 68, figs $2,7-11$ ) & Indet. \\
\hline 192 & "Two-winged seeds" (pl. 68, fig. 17-22) & Seeds of Bignoniaceae \\
\hline 193 & "Probably a stone fruit" (pl. 68, fig. 25) & globose fruit, uncertain affinities \\
\hline 194 & "Probably the glume of a grass" (pl. 68, fig. 26) & Indet. \\
\hline 195 & "Calyx of a flower" (pl. 68, fig. 27-29) & Macginitistemon mikanoides (MACGINITIE) MANCHESTER [Platanaceae] \\
\hline 196 & Spiny fruits, not cited & $\begin{array}{l}\text { Ceratophyllum furcatispinum HERENDEEN, LES et DILCHER } \\
\text { [Ceratophyllaceae] }\end{array}$ \\
\hline
\end{tabular}

Appendix Table 1. USGS localities providing the basis for Brown's (1962) synthesis. Taxon list numbers correspond to those in Table 2 and are based mainly on data provided by Brown (1962).

\begin{tabular}{|c|c|c|c|c|c|}
\hline $\begin{array}{l}\text { Locality } \\
\text { number }\end{array}$ & Brief Description & $\begin{array}{c}\text { Latitude, Longitude } \\
\text { [and original coordinates] }\end{array}$ & Collectors, Date & Taxon list & Reference \\
\hline 317 & $\begin{array}{l}\text { South Table Mountain, } \\
\text { Golden, CO }\end{array}$ & $39.745933^{\circ},-105.199616^{\circ}$ & $\begin{array}{l}\text { A. Lakes, June 1890, } \\
\text { H.C. Beckwith }\end{array}$ & $\begin{array}{l}6,7,10,13,20,24,32,43,45,49,67 \\
70,71,74,75,79,82,90,96,99,100 \\
124,126,127,129,131,132,138,139 \\
147,149,150,151,159,165,167,168 \\
169,170,171,175\end{array}$ & $\begin{array}{l}9,21,22,29,38 \\
41,49,57,81\end{array}$ \\
\hline 318 & $\begin{array}{l}\text { NW side of Green Mountain, } \\
\text { Golden, } \mathrm{CO}\end{array}$ & $39.705858^{\circ},-105.185932^{\circ}$ & A. Lakes, 1890 & $7,16,124$ & $9,22,41,57$ \\
\hline 320 & $\begin{array}{l}\text { South Table Mountain, } \\
\text { Golden, CO }\end{array}$ & $39.749116^{\circ},-105.163397^{\circ}$ & $\begin{array}{l}\text { A. Lakes, June 1890, } \\
\text { H.C. Beckwith }\end{array}$ & Missing Data & $\begin{array}{l}9,21,22,29,38 \\
41,49,57,81\end{array}$ \\
\hline 321 & $\begin{array}{l}\text { South Table Mountain, } \\
\text { Golden, CO }\end{array}$ & $39.738672^{\circ},-105.206820^{\circ}$ & $\begin{array}{l}\text { A. Lakes, June 1890, } \\
\text { H.C. Beckwith }\end{array}$ & Missing Data & $\begin{array}{l}9,21,22,29,38 \\
41,49,57\end{array}$ \\
\hline 322 & $\begin{array}{l}\mathrm{N} \text { face of South Table Mt., } \\
\text { Golden, } \mathrm{CO}\end{array}$ & $39.761023^{\circ},-105.197532^{\circ}$ & A. Lakes, 1890 & 8 & $9,22,57$ \\
\hline 324 & $\begin{array}{l}\text { South Table Mountain, } \\
\text { Golden, CO }\end{array}$ & $39.746576^{\circ},-105.194418^{\circ}$ & $\begin{array}{l}\text { A. Lakes, June 1890, } \\
\text { H.C. Beckwith }\end{array}$ & Missing Data & $\begin{array}{l}9,21,22,29,38 \\
41,49,57,81\end{array}$ \\
\hline 325 & $\begin{array}{l}\text { 3,000 ft E of Douglas (Lehigh) } \\
\text { coal mine, } 3 \text { mi W of } \\
\text { Sedalia, CO }\end{array}$ & $39.437321^{\circ},-105.016653^{\circ}$ & A. Lakes, 18 June, 1890 & $7,9,13,15,71,74,138,139,147,169$ & $9,41,49,57,64$ \\
\hline
\end{tabular}




\begin{tabular}{|c|c|c|c|c|c|}
\hline $\begin{array}{l}\text { Locality } \\
\text { number }\end{array}$ & Brief Description & $\begin{array}{c}\text { Latitude, Longitude } \\
\text { [and original coordinates] }\end{array}$ & Collectors, Date & Taxon list & Reference \\
\hline 326 & $\begin{array}{l}\text { Sandstone at coal seam in } \\
\text { Laramie at Morrison, } \\
\text { CO (Cretaceous) }\end{array}$ & $39.648848^{\circ},-105.135235^{\circ}$ & A. Lakes, June 1890 & 6 & $9,22,41,57$ \\
\hline 331 & $\begin{array}{l}1,900 \mathrm{ft} \mathrm{E} \text { of Douglas (Lehigh) } \\
\text { coal mine, Sedalia, CO }\end{array}$ & $39.437124^{\circ},-105.020211^{\circ}$ & A. Lakes, June 1890 & $131,132,136$ & $9,22,41,57$ \\
\hline \begin{tabular}{|l|}
333,334 \\
335,8788 \\
\end{tabular} & $\begin{array}{l}\text { N side of Potato Hill Gap, } 2 \text { mi } \\
\text { E of Hot Sulphur Springs, CO }\end{array}$ & $40.085064^{\circ},-106.076361^{\circ}$ & G.L. Cannon, summer, 1889 & $13,16,18,22,27,96,131$ & 9,57 \\
\hline 336 & $\begin{array}{l}\text { Near Sheriff's coal shaft on } \\
\text { Sheriff Cr., E of Hot Sulphur } \\
\text { Springs, CO }\end{array}$ & $40.088724^{\circ},-106.069460^{\circ}$ & G.L. Cannon, summer, 1889 & $8,87,114$ & $9,49,57$ \\
\hline $\begin{array}{c}337,338 \\
8787\end{array}$ & $\begin{array}{l}\text { Mount Bross, Hot Sulphur } \\
\text { Springs, CO }\end{array}$ & $40.079311^{\circ},-106.112206^{\circ}$ & G. L. Cannon, summer, 1889 & $\begin{array}{l}18,32,72,78,86,87,96,105,114 \\
131,136,145,146,151,191\end{array}$ & 9,57 \\
\hline 436 & Red Lodge, MT & $45.183631^{\circ},-109.241900^{\circ *}$ & W.H. Weed, 1891 & 40,63 & $9,57,78$ \\
\hline 541 & $\begin{array}{l}\text { Head of Buck Cr., Niobrara } \\
\text { Co., WY }\end{array}$ & $43.173673^{\circ},-104.528630^{\circ} *$ & J.B. Hatcher, $1892 ?$ & $51,59,110$ & $9,25,56,57$ \\
\hline 607 & $\begin{array}{l}\text { Sweetgrass Cr., W of Porcupine } \\
\text { Butte, MT }\end{array}$ & $46.148061^{\circ},-110.175994^{\circ}$ & W.H. Weed, July 5, 1892 & 14,153 & $9,42,57,74$ \\
\hline 1468 & $\begin{array}{l}\text { Lightning Cr., } 2 \text { mi above } \\
\text { mouth of Walker Cr., } \\
\text { Lance Cr., WY }\end{array}$ & $43.151833^{\circ},-104.869980^{\circ}$ & $\begin{array}{l}\text { F.H. Knowlton \& T.W. Stanton, } \\
\text { July } 15,1896\end{array}$ & 96 & 9,57 \\
\hline 1471 & Almy, WY, Mine no. 6 & $41.341111^{\circ},-111.000000^{\circ}$ & $\begin{array}{l}\text { T.W. Stanton \& F.H. Knowlton, } \\
\text { Aug. } 14,1896\end{array}$ & 161 & $9,57,70$ \\
\hline 1474 & Almy, WY, Mine No. 5 & $41.331905^{\circ},-110.989131^{\circ}$ & $\begin{array}{l}\text { Stanton \& F.H. Knowlton, } \\
\text { Aug. 14, } 1896\end{array}$ & 72 & $9,57,70$ \\
\hline 1502 & $\begin{array}{l}2^{1 / 2} \text { miles SE of Black Buttes, } \\
\text { WY }\end{array}$ & $41.518253^{\circ},-108.657314^{\circ}$ & F.H. Knowlton, Aug. 4-5, 1896 & $18,87,122$ & $9,57,66$ \\
\hline 2414 & $\begin{array}{l}\text { Clear Cr., } 6 \mathrm{mi} \text { N of Yellow- } \\
\text { stone R., } 15 \mathrm{mi} \text { above } \\
\text { Glendive, MT }\end{array}$ & $46.984775^{\circ},-104.901808^{\circ}$ & L.F. Ward, Aug. 1883 & $\begin{array}{l}22,58,63,68,69,78,79,136 \\
155,156\end{array}$ & $9,57,79$ \\
\hline $\begin{array}{l}2416 \\
2426 \\
8196\end{array}$ & $\begin{array}{l}6 \mathrm{mi} \text { above mouth Sevenmile } \\
\text { Cr., } 10 \mathrm{mi} \text { NE of Glendive, MT }\end{array}$ & $47.257583^{\circ},-104.716747^{\circ}$ & L.F. Ward, Aug. 9-12, 1883 & $\begin{array}{l}18,29,32,34,37,40 \mathrm{a}, 45,58,69,72 \\
78,80,83,85,96,102,104,122,139 \\
147,156,157\end{array}$ & $\begin{array}{l}9,43,57,71 \\
72,79\end{array}$ \\
\hline $\begin{array}{l}2417 \\
2418 \\
2427 \\
\end{array}$ & $\begin{array}{l}\text { Crackerbox Cr., } 18 \mathrm{mi} \text { NW of } \\
\text { Glendive, MT }\end{array}$ & $46.954150^{\circ},-104.975531^{\circ}$ & C.A. White, July 28, 1882. & $6,22,41,153,187$ & 9,78 \\
\hline 2420 & Burns, Montana & $447.372667^{\circ},-104.399397^{\circ}$ & C.A. White, Aug. 17, 1882 & $\begin{array}{l}1,3,23,25,33,34,40,79,85,96 \\
98,104,119,131,142,154,178\end{array}$ & $9,57,79$ \\
\hline 2421 & $\begin{array}{l}\text { Iron Bluff, } 12 \text { mi SW of } \\
\text { Glendive, MT } \\
\end{array}$ & $46.956147^{\circ},-104.795483^{\circ}$ & C.A. White, Aug 3, 1882 & $18,40,104,142$ & $9,43,57,78$ \\
\hline 2422 & $\begin{array}{l}2 \text { mi E of Gladstone, N side } \\
\text { of Heart R., ND }\end{array}$ & $46.847440^{\circ},-102.528021^{\circ}$ & A.C. Peale, Sept. 21, 1883 & $104,122,153$ & $9,38,57$ \\
\hline $\begin{array}{l}2423 \\
4984\end{array}$ & $\begin{array}{l}\text { Bull Mountains, } 40 \mathrm{mi} \mathrm{N} \text { of } \\
\text { Billings, MT }\end{array}$ & $46.240131^{\circ},-108.342221^{\circ}$ & $\begin{array}{l}\text { F.V. Hayden \& A.C. Peale, } \\
\text { Aug. } 17,1883\end{array}$ & $33,34,54,57,72,78,104,110$ & $9,30,57,79$ \\
\hline 2424 & near Medora, ND & $46.921803^{\circ},-103.540719^{\circ}$ & F.V. Hayden \& A.C. Peale, 1883 & \begin{tabular}{|l|l|}
79,155 \\
\end{tabular} & 9,57 \\
\hline 2432 & $\begin{array}{l}\text { Iron Bluff, } 12 \text { mi SW of } \\
\text { Glendive, MT }\end{array}$ & $46.956147^{\circ},-104.795483^{\circ}$ & L.F. Ward, 15-17 July, 1883 & $23,51,95,131$ & $8,9,43,57$ \\
\hline 3563 & $1 \mathrm{mi}$ N-NE Nugget, WY & $41.837286^{\circ},-110.816953^{\circ}$ & Missing Data & 33 & 9 \\
\hline $\begin{array}{l}3653 \\
5538 \\
5542\end{array}$ & $\begin{array}{l}\text { Evanston, WY, RR cut, } 1 \mathrm{mi} \mathrm{E} \\
\text { of RR station }\end{array}$ & $41.268069^{\circ},-110.946592^{\circ}$ & A.C. Veatch, June 23, 1905 & $72,87,96,131,136$ & 9,57 \\
\hline $\begin{array}{l}3658 \\
5539\end{array}$ & Almy, WY, Mine No. 7 & $41.346311^{\circ},-111.000046^{\circ}$ & A.C. Veatch, 1905 & $57,78,82,84,96,131,151$ & $9,57,70$ \\
\hline 3661 & Almy, WY & $41.345406^{\circ},-110.998336^{\circ}$ & A.C. Veatch, 6 July, 1905 & $57,83,84,96$ & 9,57 \\
\hline 3667 & Near Evanston, WY & $41.318369^{\circ},-110.962281^{\circ}$ & A.C. Veatch, 6 July, 1905 & 15 & 9,57 \\
\hline 3728 & $\begin{array}{l}\text { Mouth of Cedar Coulee, } 4 \mathrm{mi} \\
\text { SE of Williston, ND }\end{array}$ & $48.111058^{\circ},-103.547936^{\circ}$ & M.R. Campbell, 13 July, 1905 & 122 & $9,32,57$ \\
\hline 3852 & $\begin{array}{l}\text { Meeyero Cr., } 8 \text { mi SW } \\
\text { of Winchester P.O., WY }\end{array}$ & $43.777977^{\circ},-108.278140^{\circ *}$ & C.A. Fisher, 1905 & $87,96,99,114,132$ & 9,57 \\
\hline 3963 & $\sim 7.3 \mathrm{mi} \mathrm{W}$ of Hanna, WY & \begin{tabular}{|l|}
$41.858864^{\circ},-106.698117^{\circ}$ \\
1 [SE sec. 24, T. $22 \mathrm{~N}$, R. $83 \mathrm{~W}]$ \\
\end{tabular} & Missing Data & 191 & 9 , \\
\hline $\begin{array}{l}3979 \\
4325\end{array}$ & $\begin{array}{l}\text { Signal Butte, } 5 \text { mi SE of } \\
\text { Miles City, MT }\end{array}$ & $46.390350^{\circ},-105.757889^{\circ}$ & $\begin{array}{l}\text { Leonard, Holgate \& Clark, } \\
\text { Aug. } 28 \text { and Sept. 1, } 1906\end{array}$ & $58,69,83,84$ & $9,15,51,52,57$ \\
\hline 3980 & $\begin{array}{l}\text { Left bank Yellowstone R. } \\
\text { across from Miles City, MT }\end{array}$ & $46.422247^{\circ},-105.860586^{\circ}$ & $\begin{array}{l}\text { A.G. Leonard, W.R. Holgate, } \\
\text { W.H. Clark, Sept. 3, } 1906\end{array}$ & $89,142,146$ & 9,57 \\
\hline 4005 & $12 \mathrm{mi}$ SW of Glendive, MT & $46.956283^{\circ},-104.795492^{\circ}$ & $\begin{array}{l}\text { Campbell, Leonard, Holgate } \\
\text { \& Clark, July 31, } 1906\end{array}$ & 104 & 9,57 \\
\hline 4010 & $4 \mathrm{mi}$ SW of Winchester P.O., WY & $43.817897^{\circ},-108.217008^{\circ *}$ & C.A. Fisher, Sept. 19, 1906 & 61 & 9,57 \\
\hline 4028 & $\begin{array}{l}\text { Turner ranch, } 20 \mathrm{mi} \mathrm{NW} \text { of } \\
\text { Jordan, MT }\end{array}$ & $47.508258^{\circ},-107.170894^{\circ *}$ & $\begin{array}{l}\text { A.G. Leonard, W.R. Holgate } \\
\text { \& W.H. Clark, Sept. 25, } 1906\end{array}$ & 18,36 & 9,51 \\
\hline 4029 & $13 \mathrm{mi} \mathrm{N}$ of Jordan, MT & $47.498817^{\circ},-106.935753^{\circ *}$ & $\begin{array}{l}\text { A.G. Leonard, W.R. Holgate } \\
\text { \& W.H. Clark, Sept. 21, } 1906\end{array}$ & 15,14 & $9,51,57$ \\
\hline 4031 & $\begin{array}{l}\text { Kern ranch, } 24 \mathrm{mi} \mathrm{NW} \text { of } \\
\text { Jordan, MT }\end{array}$ & $47.583886^{\circ},-107.255092^{\circ *}$ & $\begin{array}{l}\text { A.G. Leonard, W.R. Holgate } \\
\text { \& W.H. Clark, Sept. 25, } 1906\end{array}$ & $26,40,175$ & $9,51,57$ \\
\hline 4032 & $\begin{array}{l}\text { Alkali Cr., } 27 \mathrm{mi} \text { NW of } \\
\text { Miles City, MT }\end{array}$ & $?$ & Missing Data & $77,79,96$ & 9 \\
\hline 4035 & $\begin{array}{l}3 \text { mi S of Griers Ranch, near } \\
\text { Miles City, MT }\end{array}$ & $\sim$ T. 14 N, R. $42 \mathrm{~S}$ & $\begin{array}{l}\text { A.G. Leonard \& W.R. Holgate, } \\
\text { Sept. 11, } 1906\end{array}$ & 69,79 & 9,57 \\
\hline
\end{tabular}




\begin{tabular}{|c|c|c|c|c|c|}
\hline $\begin{array}{l}\text { Locality } \\
\text { number }\end{array}$ & Brief Description & \begin{tabular}{|c|} 
Latitude, Longitude \\
[and original coordinates]
\end{tabular} & Collectors, Date & Taxon list & Reference \\
\hline 4050 & $\begin{array}{l}\text { 3/4 mi E of Florida R. crossing, } \\
\text { E of Durango, CO }\end{array}$ & $37.274783^{\circ},-107.781053^{\circ}$ & C.D. Smith for J.A. Taff 1906 & 110 & $9,25,57$ \\
\hline 4256 & $1 \frac{1}{2} \mathrm{mi}$ NW of Coleharbor, ND & $47.556258^{\circ},-101.250153^{\circ}$ & $\begin{array}{l}\text { F.H. Knowlton \& A.C. Peale, } \\
\text { June } 29,1907\end{array}$ & 96 & $9,37,57$ \\
\hline $\begin{array}{l}4262 \\
4264\end{array}$ & $\begin{array}{l}\text { W side of Little Missouri R., } \\
2 \text { mi S of Medora, ND }\end{array}$ & $46.905426^{\circ},-103.552291^{\circ}$ & F.H. Knowlton, July 8, 1907 & $33,51,54,67,96,156,157,158,180$ & $9,43,57$ \\
\hline 4268 & $\begin{array}{l}\text { Face of Picket Butte, near } \\
\text { Custer Trail Ranch, } 4 \text { mi S of } \\
\text { Medora, ND }\end{array}$ & $46.859119^{\circ},-103.532078^{\circ}$ & $\begin{array}{l}\text { F.H. Knowlton \& A.C. Peale, } \\
\text { July } 11,1908\end{array}$ & 39 & $9,25,57$ \\
\hline 4272 & $\begin{array}{l}\text { Custer Trail Ranch } 1 / 4 \mathrm{mi} \mathrm{SE} \\
\text { of mouth of Davis Cr., S of } \\
\text { Medora, ND }\end{array}$ & $46.877470^{\circ},-103.531483^{\circ}$ & $\begin{array}{l}\text { F.H. Knowlton \& A.C. Peale, } \\
\text { July } 12,1907\end{array}$ & 6,88 & $9,43,57$ \\
\hline 4273 & $\begin{array}{l}\text { Custer Trail Ranch, } 1 / 4 \mathrm{mi} \mathrm{SE} \\
\text { of mouth of Davis Cr., S of } \\
\text { Medora, ND }\end{array}$ & $46.866350^{\circ},-103.527175^{\circ}$ & $\begin{array}{l}\text { F.H. Knowlton \& A.C. Peale, } \\
\text { July } 12,1907\end{array}$ & 9,96 & $9,43,47,57$ \\
\hline 4280 & $\begin{array}{l}\text { S side of Yellowstone R., } \\
\text { opposite Harpster's Ranch, } \\
\sim 10 \mathrm{mi} \text { NE of Glendive, MT }\end{array}$ & $47.219964^{\circ},-104.625142^{\circ}$ & $\begin{array}{l}\text { F.H. Knowlton \& A.C. Peale } \\
\text { July } 22,1907\end{array}$ & 132 & $9,43,57$ \\
\hline 4289 & $\begin{array}{l}\text { Hedges Coal Mine, N side of } \\
\text { Yellowstone R. opposite Miles } \\
\text { City, MT }\end{array}$ & $46.431919^{\circ},-105.839714^{\circ}$ & $\begin{array}{l}\text { F.H. Knowlton, A.C. Peale \& } \\
\text { A.J. Collier, Aug. 3, } 1907\end{array}$ & 63 & 9,43 \\
\hline 4293 & $\begin{array}{l}\text { Hedges coal mine, } \mathrm{N} \text { side of } \\
\text { Yellowstone R., } 1 \mathrm{mi} \mathrm{N} \text { of } \\
\text { Miles City, MT }\end{array}$ & $46.431919^{\circ},-105.839714^{\circ}$ & $\begin{array}{l}\text { A.C. Peale, A.J. Collier \& F.H. } \\
\text { Knowlton, Aug. 3, } 1907\end{array}$ & 2 & $9,14,57$ \\
\hline 4310 & $\begin{array}{l}3 \text { mi N of Clyde Park, E side } \\
\text { of Shields R., MT }\end{array}$ & $45.925758^{\circ},-110.613458^{\circ}$ & $\begin{array}{l}\text { F.H. Knowlton, A.C. Peale \& } \\
\text { D. White, Sept 4, } 1907\end{array}$ & 58 & 9,57 \\
\hline 4311 & $\begin{array}{l}2 \text { mi N of Clyde Park, opposite } \\
\text { of crossing of rd to Myersburg, } \\
\text { E side of Shields R., MT }\end{array}$ & $45.906169^{\circ},-110.605553^{\circ}$ & $\begin{array}{l}\text { F.H. Knowlton, A.C. Peale \& } \\
\text { D. White, Sept 4, } 1907\end{array}$ & 72,131 & 9,57 \\
\hline 4315 & $\begin{array}{l}\text { Collier Camp, Klonder Ranch, } \\
\text { bluff E of camp, } 18 \mathrm{mi} \text { E } \\
\text { of Miles City, MT }\end{array}$ & $46.439706^{\circ},-105.533648^{\circ}$ & F.H. Knowlton, July 27, 1907 & 89,122 & $9,14,43,57$ \\
\hline 4323 & 7 mi from Miles City, MT & $46.437692^{\circ},-105.747016^{\circ}$ & $\begin{array}{l}\text { A.J. Collier \& R.W. Howell, } \\
\text { July } 17,1907\end{array}$ & 85 & $9,14,43,57$ \\
\hline 4334 & Sentinel Butte, ND & $46.877178^{\circ},-103.848203^{\circ}$ & $\begin{array}{l}\text { F.H. Knowlton \& A.C. Peale, } \\
\text { July } 15,1907\end{array}$ & 9 & 9,57 \\
\hline 4368 & $\begin{array}{l}1 \mathrm{mi} \mathrm{N} \text { of Emerson ranch, } \\
6 \mathrm{mi} \mathrm{N} \text { of Lay, CO }\end{array}$ & $40.607870^{\circ},-107.852624^{\circ}$ & Missing Data & Missing Data & 9 \\
\hline 4369 & N side of Separation Cr., WY & $41.649275^{\circ},-107.557042^{\circ}$ & T.W. Stanton, July 16, 1907 & $18,72,79,104,132$ & 9,57 \\
\hline $\begin{array}{l}4370 \\
4457 \\
8774\end{array}$ & $\begin{array}{l}\text { S side of Cr. in Rifle Gap, } \\
6 \text { mi N of Rifle, CO }\end{array}$ & $39.616740^{\circ},-107.765226^{\circ}$ & $\begin{array}{l}\text { T.W. Stanton, Gale 1907; } \\
\text { R.W. Brown, T.D. Lamar, } \\
\text { Sept. 11, 1937; R.W. Brown } \\
\text { and C.E.S. June 25, } 1940\end{array}$ & $\begin{array}{l}20,22,36,59,72,74,79,96,106, \\
131,132,139,140,151,154, \\
155,156,160,190\end{array}$ & 9,57 \\
\hline 4395 & 20 mi SW of Rawlins, WY & $41.584000^{\circ},-107.513494^{\circ}$ & T.W. Stanton, July 16, 1907 & 36 & 9,57 \\
\hline 4404 & $8 \mathrm{mi}$ NW of Douglas, WY & $42.802097^{\circ},-105.485672^{\circ}$ & Branson, Aug 22, 1907 & 79 & $2,9,57$ \\
\hline $\begin{array}{l}4421 \\
4882 \\
8666 \\
\end{array}$ & $\begin{array}{l}\text { Inez Mine, SW of Inez, } 3 \mathrm{mi} \mathrm{E} \\
\text { of Careyhurst, } 13 \mathrm{mi} \mathrm{W} \text { of } \\
\text { Douglas, WY }\end{array}$ & $42.834075^{\circ},-105.618106^{\circ}$ & $\begin{array}{l}\text { R.W. Brown, C.W. Mumm, } \\
\text { June 24, } 1938\end{array}$ & $8,16,74,85,99,108,141$ & 2,10 \\
\hline 4474 & $\sim 19$ mi E SE of Cody, WY & $\begin{array}{l}44.375194^{\circ},-108.709689^{\circ} \\
{[\text { SW } 1 / 4 \text { Sec. } 24, \text { T. } 51 \text { N, R. } 99 \text { W] }}\end{array}$ & H.P. Little, Aug. 5, 1907 & 22 & 9,57 \\
\hline 4514 & $6 \mathrm{mi} \mathrm{S}$ of Lennep, MT & $46.352333^{\circ},-110.481333^{\circ}$ & $\begin{array}{l}\text { F.H. Knowlton \& A.C. Peale, } \\
\text { Sept. } 13,1907\end{array}$ & 154 & 9,57 \\
\hline 4515 & $\begin{array}{l}\text { Ridge crossing near mouth of } \\
\text { Shields R. below Livingston, } \\
\text { MT }\end{array}$ & $45.727319^{\circ},-110.461351^{\circ}$ & Missing Data & Missing Data & 9 \\
\hline 4565 & $\begin{array}{l}\text { Musselshell, MT, } 600 \mathrm{ft} \text { E of } \\
\text { P.O. }\end{array}$ & $46.51826^{\circ},-108.088240^{\circ}$ & Bancroft, 1907 & 104 & 9 \\
\hline 4570 & $\begin{array}{l}3 \text { mi from head of Razor Cr., } \\
\text { MT }\end{array}$ & $46.163667^{\circ},-108.450458^{\circ}$ & L.H. Woolsey, 1907 & $72,78,96$ & $9,57,79$ \\
\hline 4571 & $\begin{array}{l}\text { SE of Roundup, E fork of } \\
\text { Razor Cr., } 3.5 \mathrm{mi} \text { NE of } \\
\text { Buckey, MT }\end{array}$ & $46.231930^{\circ},-108.421845^{\circ}$ & L.H. Woolsey, 1907 & $32,79,81,84,96,122$ & $9,57,79$ \\
\hline 4582 & 6 mi NE of Buckey, MT & $46.227961^{\circ},-108.332031^{\circ}$ & $\begin{array}{l}\text { R.W Richards, Sept. 21, 1907, } \\
\text { L.H. Woolsey }\end{array}$ & $33,63,74,86$ & $9,57,79$ \\
\hline 4617 & 6 mi SE of Lennep, MT & $46.352333^{\circ},-110.481333^{\circ}$ & $\begin{array}{l}\text { R.W. Stone, T.W. Stanton \& } \\
\text { C.A. Fisher, Aug. 27, } 1907\end{array}$ & 104 & 9,57 \\
\hline 4618 & Lebo Cr., MT & {$[\mathrm{T} 6 \mathrm{~N}, \mathrm{R} 13 \mathrm{E}]$} & $\begin{array}{l}\text { T.W. Stanton \& C.A. Fisher, } \\
\text { Sept. } 15,1907\end{array}$ & 180 & $9,57,68$ \\
\hline 4620 & Lebo Cr., MT & {$[\mathrm{T} 6 \mathrm{~N}, \mathrm{R} 13 \mathrm{E}]$} & $\begin{array}{l}\text { T.W. Stanton \& C.A. Fisher, } \\
\text { Sept. } 15,1907\end{array}$ & 68,69 & $9,57,68$ \\
\hline 4625 & $9 \mathrm{mi}$ W of Miles City, MT & $46.389689^{\circ},-106.036583^{\circ *}$ & C.D. Smith \& R.W. Howell, 1907 & $\begin{array}{l}32,71,72,79,95,96,104,131 \\
139,154\end{array}$ & 9,57 \\
\hline 4626 & Miles City, MT & $\begin{array}{l}46.431844^{\circ},-105.841208^{\circ} \\
{\left[\mathrm{SW}^{1 / 4} / \mathrm{Sec} .22, \text { T. } 8 \mathrm{~N}, \mathrm{R} .47 \mathrm{E}\right]}\end{array}$ & C. Smith, 1907 & $104,146,151,155,177$ & 9,57 \\
\hline $\begin{array}{l}4661 \\
6666\end{array}$ & near Ilo PO, WY & $\begin{array}{l}43.892819^{\circ},-108.524697^{\circ} \\
{\left[\mathrm{SW}^{1} / 4 \text { Sec. } 5, \text { T. } 45 \text { N, R. } 97 \mathrm{~W}\right]}\end{array}$ & E.G. Woodruff, 1907 & $\begin{array}{l}13,16,29,33,34-37,57,79,83,86 \\
96,104,105,150,151,164\end{array}$ & $9,35,47,57$ \\
\hline 4665 & $2 \mathrm{mi} \mathrm{N}$ of Ilo $\mathrm{PO}, \mathrm{WY}$ & $43.940575^{\circ},-108.536772^{\circ}$ & E.G. Woodruff, Sept. 2, 1907 & $32,74,78,87,99,127,153,155$ & $9,35,47,57$ \\
\hline 4674 & On Shoshone R., Cody, WY & $44.561028^{\circ},-108.996919^{\circ}$ & $\begin{array}{l}\text { Willard, F.H. Knowlton, } \\
\text { E.G. Woodruff, } 1907\end{array}$ & 96 & $9,34,57$ \\
\hline
\end{tabular}




\begin{tabular}{|c|c|c|c|c|c|}
\hline $\begin{array}{l}\text { Locality } \\
\text { number }\end{array}$ & Brief Description & \begin{tabular}{|c|} 
Latitude, Longitude \\
[and original coordinates]
\end{tabular} & Collectors, Date & Taxon list & Reference \\
\hline 4676 & $\begin{array}{l}\text { E side of divide between Red } \\
\text { Lodge and Bear Cr., MT }\end{array}$ & $45.183046^{\circ},-109.206218^{\circ *}$ & $\begin{array}{l}\text { T.W. Stanton, C.A. Fisher, } \\
\text { \& Schranun } 1907\end{array}$ & 72 & 9,57 \\
\hline 4688 & Shoshone R., below Cody, WY & $?$ & F.H. Knowlton et al. & 51 & 9 \\
\hline 4694 & $\begin{array}{l}\text { Roof of Black Diamond Mine, } \\
3 \text { mi N of Meeteetse, WY } \\
\end{array}$ & $44.197581^{\circ},-108.895569^{\circ}$ & E.G. Woodruff, Aug. 18, 1907 & $11,32,99$ & 9,57 \\
\hline 4696 & $9 \mathrm{mi}$ SW of Bridger, MT & $45.203774^{\circ},-109.041110^{\circ *}$ & F.H. Knowlton, 1907 & 30,84 & 9,57 \\
\hline 4699 & $\begin{array}{l}\text { SE corner of Ft Keogh Military } \\
\text { Res. on Tongue R., } \\
\text { Miles City, MT } \\
\end{array}$ & $46.299142^{\circ},-105.776853^{\circ *}$ & C.D. Smith, 1907 & 104,131 & $9,14,57$ \\
\hline 4725 & near Rock Springs, WY & $\begin{array}{l}41.591250^{\circ},-108.628692^{\circ} \\
{[\text { S ctr. Sec. } 25, \text { T. } 19 \text { N, R. } 100 \text { W] }}\end{array}$ & Missing Data & 81 & 9,57 \\
\hline 4843 & $\begin{array}{l}\sim 19 \text { m due N of Rock } \\
\text { Springs, WY } \\
\end{array}$ & \begin{tabular}{|l|}
$41.865475^{\circ},-109.160047^{\circ *}$ \\
{$[S W 1 / 4$, sec. 23, T. $22 \mathrm{~N}$, R. $104 \mathrm{~W}]$} \\
\end{tabular} & Missing Data & Missing Data & 9 \\
\hline 4860 & $3 / 4$ mi NW of Beckton, WY & $\begin{array}{l}44.765181^{\circ},-107.141467^{\circ} \\
{[\text { Sec. 2, T. } 57 \text { N, R. } 85 \text { W] }} \\
\end{array}$ & \begin{tabular}{|l|} 
T.E. Willard \& A.W. \\
Thompson, July 17, 1907 \\
\end{tabular} & 72 & 9,57 \\
\hline 4870 & E of Stater Cr., WY & $44.928000^{\circ},-107.066072^{\circ}$ & T.E. Willard July 27,1907 & 164 & 9,57 \\
\hline 4871 & $\sim 4.2 \mathrm{mi}$ NE of Ranchester, WY & $44.942236^{\circ},-107.085014^{\circ}$ & Missing Data & $119,145,153$ & 9,57 \\
\hline 4874 & $\sim 51 / 2 \mathrm{mi}$ E of Ranchester, WY & $44.913814^{\circ},-107.070178^{\circ}$ & T.E. Williard, July 27, 1907 & 87 & 9,57 \\
\hline 4875 & $1 / 2 \mathrm{mi} \mathrm{W}$ of 4874 & $44.915925^{\circ},-107.082058^{\circ}$ & Missing Data & Missing Data & 9 \\
\hline 4876 & $3 \mathrm{mi}$ NW of Monarch, WY & $44.923447^{\circ},-107.097142^{\circ}$ & T.E. Willard, July 30, 1907 & $52,72,74,87$ & 9,57 \\
\hline 4877 & $2 \frac{1}{4} \mathrm{mi}$ NW of Monarch, WY & $44.912061^{\circ},-107.086300^{\circ}$ & T.E. Willard, July 30, 1907 & $84,94,131$ & 9,57 \\
\hline 4878 & near Monarch, WY & \begin{tabular}{|l|}
$44.897861^{\circ},-107.035358^{\circ}$ \\
{$[$ Sec. 19, T. 57 N, R. $84 \mathrm{~W}]$} \\
\end{tabular} & Missing Data & 61 & 9 \\
\hline 4879 & Upper Fort Union Formation & $?$ & Missing Data & 157,159 & 9 \\
\hline 4881 & $1 \frac{1}{2} 2 \mathrm{mi}$ SE of Monarch, WY & $44.896050^{\circ},-107.024042^{\circ}$ & T.E. Willard, Aug. 2, 1907 & 96 & 9,57 \\
\hline 4892 & $\begin{array}{l}2 \text { mi SE of Carneyville, } \\
\text { Big Goose Cr., WY } \\
\end{array}$ & $44.884259^{\circ},-106.984403^{\circ}$ & T.E. Willard, Aug. 10, 1907 & $96,157,159,164$ & 9,57 \\
\hline 4896 & $1 \mathrm{mi}$ SE of Dietz, WY & $44.864558^{\circ},-106.966586^{\circ}$ & T.E. Willard, Aug. 12, 1907 & 143,175 & 9,57 \\
\hline 4897 & W side of Tongue R., WY & $44.939467^{\circ},-106.963150^{\circ}$ & T.E. Willard, Aug. 13, 1907 & 40a, 79,155 & 9,57 \\
\hline 4898 & $3 \mathrm{mi}$ E of Carneyville, WY & $44.908406^{\circ},-106.944469^{\circ}$ & T.E. Willard, Aug. 20, 1907 & $40 a, 51,67$ & 9,57 \\
\hline 4901 & Fort Union Formation & $?$ & Missing Data & 168,175 & 9 \\
\hline 4908 & $1 / 2$ mi E of Prairie Dog Cr., WY & $44.911525^{\circ},-106.847075^{\circ}$ & T.E. Willard, Aug. 19, 1907 & 96,104 & 9,57 \\
\hline 4909 & $3 / 4$ mi E of Prairie Dog Cr., WY & $44.911556^{\circ},-106.844525^{\circ}$ & T.E. Willard, Aug. 19, 1907 & \begin{tabular}{|l|}
96 \\
\end{tabular} & 9,57 \\
\hline 4910 & Near Decker, MT & $45.012633^{\circ},-106.858046^{\circ *}$ & \begin{tabular}{|l|} 
J.A. Taff \& T.E. Willard, \\
Aug. 24,1907 \\
\end{tabular} & 79 & 9,57 \\
\hline $\begin{array}{l}4974, \\
4976 \\
8563 \\
\end{array}$ & $\begin{array}{l}2 \mathrm{mi} \text { E of Widdecombe } \\
\text { Brothers Ranch, } \sim 14 \mathrm{mi} \mathrm{NE} \\
\text { of Melville, MT }\end{array}$ & $46.224506^{\circ},-109.721117^{\circ}$ & \begin{tabular}{|l} 
A.C. Silberling, 1908; R.W. \\
Brown, F.S. MacNeil, A.C. \\
Silberling, Aug. 271926 \\
\end{tabular} & $40 \mathrm{a}, 58,79,84,96,131,132,156,158$ & $9,19,20,68,57$ \\
\hline $\begin{array}{l}4975 \\
8567\end{array}$ & $\begin{array}{l}\text { NW of John Widdecombe } \\
\text { Ranch, NE of Melville, MT }\end{array}$ & $46.235831^{\circ},-109.742778^{\circ}$ & $\begin{array}{l}\text { A.C. Silberling, May 14, 1908; } \\
\text { R.W. Brown, F.S. MacNeil, \& } \\
\text { A.C. Silberling, Aug. 27, } 1936 \\
\end{array}$ & $38,78,80,96,131,146,154$ & $9,19,46,57$ \\
\hline 4977 & $8 \mathrm{mi}$ E NE of Melville, MT & \begin{tabular}{|l|}
$46.152656^{\circ},-109.783606^{\circ *}$ \\
{$[$ Sec. 25, T. 5 N, R. $15 \mathrm{E}]$} \\
\end{tabular} & A.C. Silberling, June 16, 1908 & 102,184 & 9,57 \\
\hline 4979 & Lower Fort Union Formation & $?$ & Missing Data & 79 & 9 \\
\hline $\begin{array}{l}4985 \\
8568\end{array}$ & $\begin{array}{l}2.5 \text { mi SE of Buckey P.O., } \\
\text { Hwy } 87, \text { MT }\end{array}$ & $46.166600^{\circ},-108.439203^{\circ}$ & $\begin{array}{l}\text { T.W. Stanton, R.W. Richards, } \\
\text { July 5, 1908; R.W. Brown \& F.S. } \\
\text { MacNeill, Aug. 25, } 1936\end{array}$ & $36,37,57,72,78,104,110$ & $9,57,79$ \\
\hline $\begin{array}{l}5025 \\
5582 \\
\end{array}$ & $\begin{array}{l}2 \mathrm{mi} \text { E of Black Buttes, } 1 / 3 \mathrm{mi} \\
\text { from R.R. track, WY }\end{array}$ & $41.509552^{\circ},-108.622821^{\circ}$ & F.H. Knowlton, July 29, 1908 & 63 & 9,44 \\
\hline 5029 & $\begin{array}{l}35 \text { mi SW of Black Buttes, SE } \\
\text { of Mud Springs, along Brown } \\
\text { Park Stage Rd, WY } \\
\end{array}$ & $41.228937^{\circ},-108.834700^{\circ}$ & $\begin{array}{l}\text { F.H. Knowlton, A.C. Veatch, } \\
\text { C.A. Fisher, A.R. Schultz \& } \\
\text { T.W. Stanton, July 25, } 1908 \\
\end{array}$ & 10 & $9,44,57,66$ \\
\hline 5030 & $\begin{array}{l}35 \text { mi SW of Black Buttes, SE } \\
\text { of Mud Springs, along Brown } \\
\text { Park Stage Rd, WY }\end{array}$ & $41.239654^{\circ},-108.862300^{\circ}$ & $\begin{array}{l}\text { T.W. Stanton \& C.A. Fisher, } \\
\text { July } 25,1908\end{array}$ & $15,16,36$ & $9,57,66$ \\
\hline 5032 & $\begin{array}{l}\text { Head of Vermillion Cr. on } \\
\text { Brown Park Stage Rd, } \sim 47 \mathrm{mi} \\
\text { SE of Rock Springs, WY } \\
\end{array}$ & $41.236944^{\circ},-108.824969^{\circ}$ & $\begin{array}{l}\text { A.C. Veatch \& A.R. Schultz, } \\
\text { July } 26,1908\end{array}$ & 17 & 9,44 \\
\hline 5043 & Black Buttes, WY & $\begin{array}{l}41.584331^{\circ},-108.707217^{\circ} \\
{[1 / 4 \mathrm{mi} \mathrm{N} \text { of ctr., sec. } 32,} \\
\text { T. } 19 \mathrm{~N}, \text { R. } 100 \mathrm{~W}] \\
\end{array}$ & Missing Data & Missing Data & 9 \\
\hline $\begin{array}{l}5046 \\
5122\end{array}$ & $\begin{array}{l}\text { Gonzales Poison Canyon, } 5 \mathrm{mi} \\
\text { above Aguilar on Gonzales } \\
\text { Cr., CO } \\
\end{array}$ & $37.412650^{\circ},-104.738628^{\circ}$ & $\begin{array}{l}\text { G.C. Broadhead, G.B. Richardson, } \\
\text { J.H. Gardner, Sept. 4, } 1908\end{array}$ & $74,82,99,126,127,129,132,166$ & $9,45,50,57$ \\
\hline 5063 & $\begin{array}{l}\text { Bud Kimball mine on Bud } \\
\text { Kimball Draw, WY } \\
\end{array}$ & $43.905594^{\circ},-107.540433^{\circ}$ & \begin{tabular}{|l|} 
E.G. Woodruff, \\
July 19-21, 1908 \\
\end{tabular} & $32,33,96,131$ & $9,53,57$ \\
\hline $\begin{array}{l}5094 \\
5102 \\
\end{array}$ & $\begin{array}{l}3 \mathrm{mi} \mathrm{N} \text { of Trinidad, Bowen } \\
\text { Mine, near Bowen, } \mathrm{CO}\end{array}$ & $37.211881^{\circ},-104.514369^{\circ}$ & G.B. Richardson, July 17, 1908 & $30,45,46,74,99$ & $9,45,50,57$ \\
\hline 5095 & $\begin{array}{l}\text { Bear Canyon, SW of } \\
\text { Berwind, CO } \\
\end{array}$ & $37.278853^{\circ},-104.643850^{\circ}$ & Missing Data & 99 & 45,50 \\
\hline 5099 & $\begin{array}{l}\text { N slope of Raton Mesa, } 3 \mathrm{mi} \\
\text { SE of Trinidad, } 1 \frac{1}{2} \mathrm{mi} \mathrm{SW} \text { of } \\
\text { Engle, floor of Fishers Peak } \\
\text { Mine (no. 8), CO } \\
\end{array}$ & $37.132042^{\circ},-104.481539^{\circ}$ & J.H. Gardner, July 11, 1908 & $8,38,75,90,118$ & $9,57,45,50,62$ \\
\hline 5100 & $3 \mathrm{mi}$ further NW of $5697, \mathrm{CO}$ & $37.205344^{\circ},-104.605206^{\circ}$ & Missing Data & 51 & 45,50 \\
\hline 5101 & $\sim 1 \mathrm{mi} \mathrm{N}$ of Bowen, $\mathrm{CO}$ & $37.249153^{\circ},-104.523475^{\circ}$ & Missing Data & \begin{tabular}{|l|l|}
74,99 \\
\end{tabular} & 45,50 \\
\hline $\begin{array}{l}5103- \\
5105\end{array}$ & $\begin{array}{l}\text { Riley Canyon, } 2 \text { mi above } \\
\text { Cokedale, CO }\end{array}$ & $37.169931^{\circ},-104.638256^{\circ}$ & Missing Data & $18,45,70,99$ & 45,50 \\
\hline
\end{tabular}




\begin{tabular}{|c|c|c|c|c|c|}
\hline $\begin{array}{l}\text { Locality } \\
\text { number }\end{array}$ & Brief Description & $\begin{array}{c}\text { Latitude, Longitude } \\
\text { [and original coordinates] }\end{array}$ & Collectors, Date & Taxon list & Reference \\
\hline $\begin{array}{l}5106 \\
5114\end{array}$ & $\begin{array}{l}\text { E of Stonewall Gap, } 1 / 2 \mathrm{mi} \mathrm{N} \\
\text { of North Fork Purgatoire R., } \\
\text { between Virgil's and Wood's } \\
\text { ranches, CO }\end{array}$ & $37.191500^{\circ},-104.877397^{\circ}$ & Missing Data & 45,99 & 45,50 \\
\hline 5107 & $1 \frac{1}{2} \mathrm{mi} \mathrm{SW}$ of Berwind, $\mathrm{CO}$ & $37.292947^{\circ},-104.643606^{\circ}$ & Missing Data & 79,132 & 45,50 \\
\hline $\begin{array}{l}5111 \\
5112 \\
5695\end{array}$ & $\begin{array}{l}\text { Powell Arroyo, } 5 \mathrm{mi} \mathrm{NW} \text { of } \\
\text { Trinidad, or } 3 \mathrm{mi} \mathrm{W} \text { of } \\
\text { Bowen, CO }\end{array}$ & $37.238431^{\circ},-104.560117^{\circ}$ & W.T. Lee, 1910 & $45,99,141,152,159$ & $9,45,50$ \\
\hline 5113 & 2 mi SE of Dean, Colorado Bowen & $37.264144^{\circ},-105.036256^{\circ}$ & Missing Data & 74,132 & 45,50 \\
\hline 5118 & $\begin{array}{l}\text { SW of } 5684,3 \mathrm{mi} \text { above } \\
\text { Aguilar, CO }\end{array}$ & $37.414070^{\circ},-104.696584^{\circ}$ & Missing Data & 86 & 45,50 \\
\hline 5120 & $\begin{array}{l}\text { Mine \# 37, } 4 \mathrm{mi} \mathrm{SW} \text { of } \\
\text { Berwind, CO }\end{array}$ & $37.282931^{\circ},-104.671114^{\circ}$ & Missing Data & 71 & 45,50 \\
\hline 5121 & $\begin{array}{l}\text { Poison Canyon, S of Apishap } \\
\text { R., } 7 \text { mi SW of Berwind, CO }\end{array}$ & $37.270897^{\circ},-104.743078^{\circ}$ & J.H. Gardner, Aug. 30, 1908 & 74,96 & $9,45,50,57$ \\
\hline 5123 & $4 \mathrm{mi}$ above Aguilar, $\mathrm{CO}$ & $37.413750^{\circ},-104.724364^{\circ}$ & Missing Data & 79 & 45,50 \\
\hline 5124 & $1 \frac{1}{2}$ miles NW of $5687, \mathrm{CO}$ & $37.365883^{\circ},-104.762119^{\circ}$ & Missing Data & 74 & 45,50 \\
\hline 5132 & $\begin{array}{l}\text { Normans Ranch, } \sim 1 \text { mi NE of } \\
\text { Yankee, } 12 \text { mi E of Raton, S } \\
\text { extremity of Barilla Mesa, NM }\end{array}$ & $36.978242^{\circ},-104.302767^{\circ}$ & W.T. Lee, 1908 & $74,79,99,152$ & $9,45,50,57$ \\
\hline 5133 & $\begin{array}{l}\text { Roof of Raynolds coal mine, } \\
\text { NM }\end{array}$ & $36.978944^{\circ},-104.321078^{\circ}$ & W.T. Lee, 1908 & 45,99 & $9,45,50,57$ \\
\hline 5134 & $\begin{array}{l}\text { E wall of gulch near Yankee } \\
\text { Mine } \# 5 \text {, highest rocks exposed } \\
\text { at } 5139, \text { near Raton, NM }\end{array}$ & $36.891789^{\circ},-104.322046^{\circ}$ & W.T. Lee, 1908 & $78,79,84,127$ & $9,45,50,57$ \\
\hline 5135 & $\begin{array}{l}\text { E wall of gulch near Yankee } \\
\text { Mine \#5, } 50 \mathrm{ft} \text { higher of } 5137 \text {, } \\
\text { near Raton, NM }\end{array}$ & $36.891789^{\circ},-104.322046^{\circ}$ & Missing Data & 74 & $9,45,50,57$ \\
\hline 5137 & $\begin{array}{l}\text { E wall of gulch near Yankee } \\
\text { Mine \#5, } 50 \mathrm{ft} \text { higher of } 5138 \text {, } \\
\text { near Raton, NM }\end{array}$ & $36.891789^{\circ},-104.322046^{\circ}$ & W.T. Lee, 1908 & $74,96,99$ & $9,45,50,57$ \\
\hline 5138 & $\begin{array}{l}\text { E wall of gulch E of Yankee } \\
\text { Mine \#5. at } 5139, \text { near } \\
\text { Raton, NM }\end{array}$ & $36.891789^{\circ},-104.322046^{\circ}$ & Missing Data & 79 & $9,45,50,57$ \\
\hline 5139 & $\begin{array}{l}\text { E wall of gulch, near Yankee } \\
\text { Mine \#5, NM }\end{array}$ & $36.891789^{\circ},-104.322046^{\circ}$ & W.T. Lee, 1908 & 45 & $9,45,50,57$ \\
\hline 5140 & $\begin{array}{l}\text { near Yankee, NM, old } \\
\text { Honeyfield Mine }\end{array}$ & $36.900311^{\circ},-104.334674^{\circ}$ & W.T. Lee, 1908 & $18,82,84,96,99,104,139$ & $9,45,50,57$ \\
\hline 5141 & $\begin{array}{l}\text { near Yankee, NM, old } \\
\text { Honeyfield Mine, } 125-200 \mathrm{ft} \\
\text { above } 5140\end{array}$ & $36.944017^{\circ},-104.351883^{\circ}$ & W.T. Lee, 1908 & 79 & $9,45,50,57$ \\
\hline 5142 & $\begin{array}{l}\text { Gulch mi SE of Raynolds } \\
\text { coal mine, near Yankee, NM }\end{array}$ & $36.977611^{\circ},-104.311206^{\circ}$ & W.T. Lee, 1908 & $45,47,53,74,76,82,99,129,147,151$ & $9,45,50,57$ \\
\hline 5143 & $\begin{array}{l}\text { Sugarite Mine (Old Wagon } \\
\text { Mine), } 1 / 2 \mathrm{mi} \text { W of site } 83,4 \mathrm{mi} \\
\mathrm{NE} \text { of Raton, NM }\end{array}$ & $36.947344^{\circ},-104.378609^{\circ}$ & Missing Data & 45,118 & 45,50 \\
\hline 5144 & $\begin{array}{l}\text { Above highest coal in Tin Pan } \\
\text { Canyon, NW of Raton, NM }\end{array}$ & $36.946818^{\circ},-104.548826^{\circ}$ & W.T. Lee, 1908 & 23 & $9,45,50,57$ \\
\hline $\begin{array}{l}5146 \\
5151\end{array}$ & $\begin{array}{l}\text { Hillside just } \mathrm{W} \text { of } \mathrm{S} \text { end of } \\
\text { Raton Tunnel, N of Raton, NM }\end{array}$ & $36.983147^{\circ},-104.491975^{\circ}$ & F.H. Knowlton & $\begin{array}{l}45,46,51,74,79,86,99,104, \\
126,132\end{array}$ & $9,45,50$ \\
\hline 5147 & $\begin{array}{l}\text { W side of Dillon Canyon, } \\
1 \text { mi N of mouth of Coal } \\
\text { Canyon, near Blossburg, NM }\end{array}$ & $36.933133^{\circ},-104.509331^{\circ}$ & W.T. Lee, 1908 & $46,74,99$ & $9,45,50,57$ \\
\hline $\begin{array}{l}5148 \\
5149\end{array}$ & $\begin{array}{l}\text { N wall of Dillon Canyon, NM, } \\
\text { opposite sites } 5150 \text { and } 5147\end{array}$ & $36.935031^{\circ},-104.507133^{\circ}$ & Missing Data & $45,99,129$ & 45,50 \\
\hline 5150 & $\begin{array}{l}1 / 2 \text { mi NW of mouth of Coal } \\
\text { Canyon, Dillon Canyon, near } \\
\text { Blossburg, NM }\end{array}$ & $36.930583^{\circ},-104.499303^{\circ}$ & Missing Data & 45 & 45,50 \\
\hline 5152 & Bartlett Mesa, N of Raton, NM & $36.938144^{\circ},-104.442006^{\circ}$ & Missing Data & $74,132,136$ & 45,50 \\
\hline 5154 & $\begin{array}{l}\text { Small tributary system, } 1 / 2 \\
\text { mile N of Brilliant, NM }\end{array}$ & $36.956574^{\circ},-104.523966^{\circ}$ & Missing Data & $53,99,132$ & $9,45,50$ \\
\hline 5194 & Arid R. Basin, MT & $46.240711^{\circ},-111.522319^{\circ}$ & E.G. Woodriff, Sept. 10, 1908 & $32,71,153,190$ & 9,57 \\
\hline $\begin{array}{l}5235 \\
6533\end{array}$ & $\begin{array}{l}\text { Canadian Canyon, near mouth } \\
\text { of Jones Canyon, NM }\end{array}$ & $36.915447^{\circ},-104.610650^{\circ}$ & Missing Data & 46 & 45,50 \\
\hline 5236 & $\begin{array}{l}\text { NW extremity of Vermejo Park, } \\
\text { S wall of Spring Canyon, NM }\end{array}$ & $36.957192^{\circ},-105.038986^{\circ}$ & W.T. Lee, 1908 & $71,74,83,86,126$ & $9,45,50,57$ \\
\hline 5239 & E of Vermejo Gap, NM & $36.969676^{\circ},-105.126332^{\circ} *$ & W.T. Lee, 1908 & 79,132 & 45,50 \\
\hline 5241 & $\begin{array}{l}\text { Mouth of York Canyon in } \\
\text { Vermejo Valley, NM }\end{array}$ & $36.831619^{\circ},-104.902875^{\circ}$ & Blair, 1908 & $74,79,84,132$ & 45,50 \\
\hline 5255 & 23 mi SE of Rock Springs, WY & $\begin{array}{l}41.382067^{\circ},-108.843439^{\circ} * \\
\text { [On TP line of } 46 \text { A.P.N. from } \\
\text { corner of sects. } 12 \& 13, \text { T. } 16 \mathrm{~N}, \\
\text { R. } 102 \mathrm{~W} \text { ] }\end{array}$ & G.E.Burton, Aug. 14, 1908 & 23 & 9,57 \\
\hline 5259 & 23 mi SE of Rock Springs, WY & $\begin{array}{l}41.343411^{\circ},-108.873303^{\circ} \\
{[\mathrm{NE} 1 / 4 \mathrm{NE} 1 / 4, \text { Sec. } 27, \text { T. } 16 \mathrm{~N},} \\
\text { R. } 102 \mathrm{~W}]\end{array}$ & G.E. Burton, Aug. 17, 1908 & 51 & 9,57 \\
\hline 5291 & $\begin{array}{l}\text { Canadian (Red) Canyon, } 1 \mathrm{mi} \\
\text { E of Jones Canyon, NM }\end{array}$ & $36.903661^{\circ},-104.594675^{\circ}$ & W.T. Lee, 1908 & $79,99,127,132$ & $9,23,45,50,57$ \\
\hline
\end{tabular}




\begin{tabular}{|c|c|c|c|c|c|}
\hline $\begin{array}{l}\text { Locality } \\
\text { number }\end{array}$ & Brief Description & \begin{tabular}{|c|} 
Latitude, Longitude \\
[and original coordinates]
\end{tabular} & Collectors, Date & Taxon list & Reference \\
\hline 5300 & $\begin{array}{l}\text { Near head of Cow Gulch, } \sim 7 \mathrm{mi} \\
\text { SE of Fattig P.O., MT }\end{array}$ & $46.285242^{\circ},-108.226811^{\circ}$ & R.W. Richards, Aug. 24, 1908 & 67 & $9,57,79$ \\
\hline 5321 & $\begin{array}{l}\text { E side of Little Bitter Cr. Rd, } \\
\text { S of Rock Springs, WY }\end{array}$ & $\begin{array}{l}41.367536^{\circ},-109.254386^{\circ} \\
\text { [On section line Sec. } 16, \text { T. } 16 \mathrm{~N}, \\
\text { R. } 105 \mathrm{~W} \text { ] }\end{array}$ & A.R. Schultz, Sept. 7, 1908 & $40 \mathrm{a}$ & 9,57 \\
\hline 5322 & $\begin{array}{l}\mathrm{N} \text { of rd across Cr. at big bend } \\
\text { in rd, S of Rock Springs, WY }\end{array}$ & $\begin{array}{l}41.495984^{\circ},-109.228018^{\circ} \\
{[\text { Sec. } 35, \text { T. } 18 \text { N, R. } 105 \mathrm{~W}]}\end{array}$ & Bartholomew, 1908 & 14 & 9,57 \\
\hline 5324 & $\sim 19$ mi S of Rock Springs, WY & $\begin{array}{l}41.311492^{\circ},-109.219458^{\circ} \\
{[\text { Sec. } 3, \text { T. } 15 \text { N, R. } 105 \mathrm{~W}]}\end{array}$ & J.L. Rich, Sept. 12, 1908 & 154 & 9 \\
\hline 5332 & 4 mi E of Parkman, WY & $44.957236^{\circ},-107.249179^{\circ}$ & Missing Data & Missing Data & 9 \\
\hline 5333 & $\sim 5$ mi E of Parkman, WY & $44.958004^{\circ},-107.224324^{\circ}$ & $\begin{array}{l}\text { Pepperburg, V.H. Barnett, } \\
6 \text { Oct. } 1908\end{array}$ & 131 & 9 \\
\hline 5374 & $\begin{array}{l}\text { E bank of Jimmy Camp Cr., } \\
\text { opposite Richfield Spring, CO }\end{array}$ & $38.847772^{\circ},-104.663041^{\circ}$ & $\begin{array}{l}\text { M.Goldman \& A.C. A.C. Peale, } \\
\text { Sept. } 19,1908\end{array}$ & 71 & 9,57 \\
\hline 5385 & $\begin{array}{l}\text { Fort Peck Indian Res., right } \\
\text { bank of Missouri R., SE of } \\
\text { Brockton, MT }\end{array}$ & $48.110558^{\circ},-104.737747^{\circ}$ & E.A. Davis, Sept. 9, 1908 & 67 & $9,57,67$ \\
\hline 5387 & $\begin{array}{l}\text { Fort Peck Indian Res., near } \\
\text { mouth of Smoke Cr., MT }\end{array}$ & $48.302197^{\circ},-104.682400^{\circ}$ & C.D. Smith, Sept. 9, 1908 & 67 & 9,57 \\
\hline 5388 & $\begin{array}{l}\text { Fort Peck Indian Res., } 2 \text { mi E of } \\
\text { Ralston Ranch, SE of } \\
\text { Brockton, MT }\end{array}$ & $?$ & C.D. Smith, 1908 & 104,147 & 9,57 \\
\hline 5389 & $\begin{array}{l}\text { Fort Peck Indian Res., Balls } \\
\text { Bluff, right bank of Missouri } \\
\text { R., SE of Brockton, MT }\end{array}$ & $48.115511^{\circ},-104.832783^{\circ}$ & C.D. Smith, 1908 & 104,146 & $9,66,67$ \\
\hline $\begin{array}{l}5437 \\
5438\end{array}$ & $\begin{array}{l}\text { McCord coal bank, N side of } \\
\text { S Fork Cannon Ball R. (Cedar } \\
\text { Cr.), ND }\end{array}$ & $46.028525^{\circ},-101.719650^{\circ}$ & A.L. Beekly, April 26, 1909 & $23,96,131,141,142,175$ & $9,38,52,57$ \\
\hline 5455 & $5.7 \mathrm{mi}$ NE of Bayfield, $\mathrm{CO}$ & \begin{tabular}{|l|}
$37.288000^{\circ},-107.529686^{\circ}$ \\
{$[$ E side of Sec. 31, T. 35 N, R. $6 \mathrm{~W}]$} \\
\end{tabular} & J.H. Gardner, Aug., 7, 1909 & $53,79,85,97,99,127,132$ & $9,49,57$ \\
\hline 5456 & $\sim 7.3 \mathrm{mi}$ NE of Bayfield, $\mathrm{CO}$ & $\begin{array}{l}37.295267^{\circ},-107.506514^{\circ} \\
{[\text { SE Corner Sec. } 15, \text { T. } 35 \mathrm{~N},} \\
\text { R. } 6 \mathrm{~W}]\end{array}$ & J.H. Gardner, Aug., 1909 & 74 & $9,49,57$ \\
\hline 5460 & $\sim 5.5 \mathrm{mi} \mathrm{E}$ of Durango, $\mathrm{CO}$ & $\begin{array}{l}37.285300^{\circ},-107.783208^{\circ} \\
{[\mathrm{SE} \text { from ctr. of Sec. } 19, \text { T. } 35 \mathrm{~N},} \\
\text { R. } 8 \mathrm{~W}]\end{array}$ & $\begin{array}{l}\text { J.H. Gardner \& Heald, } \\
\text { July } 10,1909\end{array}$ & 110 & 9,57 \\
\hline 5461 & $\begin{array}{l}110 \mathrm{ft} \text { below 5460, near } \\
\text { Durango, CO }\end{array}$ & $37.285458^{\circ},-107.783464^{\circ}$ & Missing Data & 191 & 9 \\
\hline 5465 & Raton Fm. & $?$ & Missing Data & 100 & 9 \\
\hline 5467 & Raton Fm. & $?$ & Missing Data & 45,74 & 9 \\
\hline 5469 & $\begin{array}{l}\text { Bowen mine, } 5 \mathrm{mi} \mathrm{N} \text { of } \\
\text { Trinidad, } \mathrm{CO}\end{array}$ & $37.239010^{\circ},-104.508787^{\circ}$ & F.H. Knowlton, June 22, 1909 & 45 & $9,50,57$ \\
\hline 5480 & $\begin{array}{l}\text { Clinker Ballast Quarry, } \\
\text { Minturn, WY }\end{array}$ & $\begin{array}{l}44.261906^{\circ},-105.351169^{\circ} \\
{[N E 1 / 4 \mathrm{NE} 1 / 4, \text { Sec. 2, T. } 49 \mathrm{~N},} \\
\text { R. } 71 \mathrm{~W},] \\
\end{array}$ & $\begin{array}{l}\text { C.A. Fisher, T.W. Stanton, } \\
\text { R.W. Stone \& C. Lupton, } \\
\text { Oct. 7, } 1908 \\
\end{array}$ & 104 & $9,57,69$ \\
\hline 5486 & $1 / 2$ mile SW of Roundup, MT & $\begin{array}{l}46.438071^{\circ},-108.555390^{\circ} \\
{[\mathrm{NE} 1 / 4, \text { Sec. } 23, \text { T. } 8 \text { N, R. } 25 \mathrm{E}]} \\
\end{array}$ & R.W. Richards, July 7, 1908 & $29,33,79,96,156$ & 9,79 \\
\hline 5495 & $\begin{array}{l}\text { just W of crest of divide, } 5 \mathrm{mi} \\
\text { E of Hanna, WY }\end{array}$ & $\begin{array}{l}41.877753^{\circ},-106.454764^{\circ} \\
{[\text { Near middle of Sec. } 18, \text { T. } 22 \mathrm{~N},} \\
\text { R. } 80 \mathrm{~W}]\end{array}$ & T.W. Stanton, July 30, 1909 & 59 & $9,57,70$ \\
\hline 5509 & $8 \mathrm{mi}$ NE of Parkman, WY & $45.034846^{\circ},-107.217497^{\circ *}$ & $\begin{array}{l}\text { T.W. Stanton \& R.W. Stone, } \\
\text { Sept. 4, } 1909\end{array}$ & 155,164 & 9,57 \\
\hline 5512 & 7 mi NE of Parkman, WY & $45.028008^{\circ},-107.231005^{\circ} *$ & $\begin{array}{l}\text { T.W. Stanton \& R.W. Stone, } \\
\text { Sept. 5, } 1909\end{array}$ & $40 \mathrm{a}$ & 9,57 \\
\hline $\begin{array}{l}5526 \\
9112\end{array}$ & E of Ethete, WY & \begin{tabular}{|l|}
$43.049642^{\circ},-108.619900^{\circ}$ \\
{$\left[\mathrm{NE}^{1} / 4 \mathrm{SE} 1 / 4 \mathrm{Sec} .22, \mathrm{~T} .1 \mathrm{~N}, \mathrm{R} .2 \mathrm{E}\right]$} \\
\end{tabular} & E.G. Woodruff, July 21,1909 & $29,32,51,52,61,114$ & 9,57 \\
\hline 5551 & Mine No. 9, Almy, WY & ? & $\begin{array}{l}\text { F.H. Knowlton \& A.C. Peale, } \\
\text { Aug. 8, } 1909\end{array}$ & 61 & 9,57 \\
\hline 5555 & Mine No. 8, Almy, WY & $?$ & $\begin{array}{l}\text { F.H. Knowlton \& A.C. Peale, } \\
\text { Aug. } 8,1909\end{array}$ & 84,96 & 9,57 \\
\hline 5557 & $\begin{array}{l}\text { Ridge above coal mines No. } 1 \\
\text { and 4, Almy, WY }\end{array}$ & $41.320724^{\circ},-110.987438^{\circ}$ & Missing Data & Missing Data & 9 \\
\hline 5578 & $\begin{array}{l}4 \text { mi SE of Black Buttes, on rd } \\
\text { to Bitter Cr., WY }\end{array}$ & $41.508794^{\circ},-108.640194^{\circ}$ & $\begin{array}{l}\text { F.H. Knowlton \& A.C. Peale, } \\
\text { July } 27,1909\end{array}$ & 87,122 & $9,57,66$ \\
\hline 5579 & 1 $1 \frac{1}{2}$ mi E of Black Buttes, WY & $41.548748^{\circ},-108.670830^{\circ}$ & $\begin{array}{l}\text { F.H. Knowlton \& A.C. Peale, } \\
\text { July } 26,1909\end{array}$ & 32,98 & $9,57,66$ \\
\hline $\begin{array}{l}5594 \\
5595 \\
5596\end{array}$ & $\begin{array}{l}\text { SE side of coulee, } 14 \mathrm{mi} \mathrm{S} \text { of } \\
\text { ctr. of Chinook, MT }\end{array}$ & $\begin{array}{l}48.416803^{\circ},-109.280917^{\circ} \\
{[\mathrm{SW} 1 / 4 \mathrm{NW} 1 / 4, \text { Sec. } 28, \text { T. } 31 \mathrm{~N},} \\
\text { R. } 19 \mathrm{E}]\end{array}$ & $\begin{array}{l}\text { L.J. Pepperberg, Sept. 15, 1909; } \\
\text { R.W. Brown \& D.B. Stewart, } \\
\text { Aug. 20, } 1949\end{array}$ & $29,33,37,54,78,87,104,195$ & $9,57,59$ \\
\hline 5609 & $2 \mathrm{mi}$ N of Musselshell, MT & $46.546028^{\circ},-108.093402^{\circ}$ & $\begin{array}{l}\text { R.W. Stone, B. Kennedy, } \\
\text { June 15, } 1909\end{array}$ & $32,37,79,96,139,147,154$ & $9,57,79$ \\
\hline 5611 & $2 \frac{1}{2} 2 \mathrm{mi} \mathrm{N}$ of Musselshell, MT & $46.551441^{\circ},-108.104499^{\circ}$ & R.W. Stone & $79,152,156$ & 9,79 \\
\hline 5612 & $3.5 \mathrm{mi}$ NE of Musselshell, MT & $\begin{array}{l}46.549332^{\circ},-108.027236^{\circ} \\
{\left[\mathrm{NW}^{1 / 4} \mathrm{NW}^{1 / 4} \mathrm{Sec} .13, \text { T. } 9 \mathrm{~N}\right.} \\
\text { R. } 29 \mathrm{E}]\end{array}$ & $\begin{array}{l}\text { R.W. Stone, B. Kennedy, } \\
\text { June 16, } 1909\end{array}$ & $33,79,86,96$ & $9,57,79$ \\
\hline 5613 & Alkali Cr. Rd., MT & \begin{tabular}{|l|}
$46.440439^{\circ},-107.836400^{\circ}$ \\
{$\left[\mathrm{SE}^{1} / 4 \mathrm{SW}^{1} / 4 \mathrm{Sec} .15\right.$, T. 8 N, R. $\left.31 \mathrm{E}\right]$} \\
\end{tabular} & C.F. Lupton, Aug. 10, 1909 & $69,78,96,153,156$ & $9,55,57,79$ \\
\hline 5614 & $10.8 \mathrm{mi}$ N of Pompeys Pillar, MT & $\begin{array}{l}46.144478^{\circ},-107.990864^{\circ} \\
{[\mathrm{NE} 1 / 4, \text { Sec. } 32, \mathrm{~T} .5 \mathrm{~N}, \mathrm{R}] 30 \mathrm{E}}\end{array}$ & C.F. Lupton & 78,191 & 9,79 \\
\hline
\end{tabular}




\begin{tabular}{|c|c|c|c|c|c|}
\hline $\begin{array}{l}\text { Locality } \\
\text { number }\end{array}$ & Brief Description & $\begin{array}{c}\text { Latitude, Longitude } \\
\text { [and original coordinates] }\end{array}$ & Collectors, Date & Taxon list & Reference \\
\hline 5618 & $\begin{array}{l}14 \mathrm{mi} \text { of Gilette, WY, } 1.2 \mathrm{mi} \\
\mathrm{W} \text { of Hwy } 59\end{array}$ & $\begin{array}{l}44.491272^{\circ},-105.494458^{\circ} \\
{[\text { Sec. } 15, \text { T. } 52 \text { N, R. } 72 \mathrm{~W}]}\end{array}$ & H. Hindus, Oct. 13, 1909 & $85,87,164$ & 9,57 \\
\hline 5619 & $\begin{array}{l}\text { At mouth of Elk Cr. on Little } \\
\text { Powder R., MT }\end{array}$ & $44.793531^{\circ},-105.376653^{\circ}$ & $\begin{array}{l}\text { C.J. Lupton \& H. Hindus, } \\
\text { Oct. } 17,1909\end{array}$ & 155 & $9,16,57$ \\
\hline 5667 & Florida R., near Durango, CO & $?$ & J.H. Gardner, Aug., 1909 & $70,96,186$ & $9,49,50$ \\
\hline 5678 & $\begin{array}{l}\text { S side of Cucharas R., } 3 \text { mi SW } \\
\text { of Walsenburg, CO }\end{array}$ & $37.598039^{\circ},-104.824465^{\circ}$ & W.T. Lee, 1910 & 74,99 & $9,41,57$ \\
\hline 5679 & $\begin{array}{l}\text { N bank of Cuchara R., } 1 / 8 \mathrm{mi} \\
\text { NE of Rockland Mine, } 3 \mathrm{mi} \\
\text { SW of Walsenburg, CO }\end{array}$ & $37.601833^{\circ},-104.826338^{\circ}$ & W.T. Lee, 1910 & $\begin{array}{l}42,46,53,70,71,74,79,91,97 \\
99,132,133,136,147,151\end{array}$ & $9,41,45,50,57$ \\
\hline 5682 & near Strong, CO & $\begin{array}{l}37.716950^{\circ},-104.901653^{\circ} \\
{[S W 1 / 4 \mathrm{NW} 1 / 4, \text { Sec. } 9, \text { T. } 27 \mathrm{~S},} \\
\text { R. } 67 \mathrm{~W}]\end{array}$ & Missing Data & 70 & 45,50 \\
\hline 5683 & $\begin{array}{l}\text { Canyon W of Old Rouse, } \\
\sim 4 \text { mi W of Mayne, CO }\end{array}$ & $37.542819^{\circ},-104.789617^{\circ}$ & W.T. Lee, 1910 & $71,79,84,86,132,147$ & $9,45,50,57$ \\
\hline 5684 & $\begin{array}{l}\text { Dump of Green Canyon mines } \\
\text { in Gonzales Canyon, near } \\
\text { Aguilar, CO }\end{array}$ & $37.425669^{\circ},-104.683889^{\circ}$ & W.T. Lee, 1910 & $\begin{array}{l}51,71,74,76,83,86,99,100, \\
101,127,132,136,152\end{array}$ & $9,45,50,57$ \\
\hline 5686 & $\begin{array}{l}\text { Apishapa Canyon, N of } \\
\text { Apishapa R., N of wagon rd, } \\
1 / 2 \text { mi W of Abeton, CO }\end{array}$ & $37.337572^{\circ},-104.726353^{\circ}$ & W.T. Lee, 1910 & $71,74,99,117,151$ & $9,45,50,57$ \\
\hline 5687 & $\begin{array}{l}\sim 1 \mathrm{mi} \text { NW of Trujillo Plaza, } \\
\mathrm{CO}\end{array}$ & $37.352894^{\circ},-104.751281^{\circ}$ & W.T. Lee, 1910 & $70,74,99,101,126$ & $9,45,50,57$ \\
\hline 5688 & $\begin{array}{l}\text { Apishapa Canyon, } 3 \mathrm{mi} \\
\mathrm{NE} \text { of Abeton, CO }\end{array}$ & $\begin{array}{l}37.351906^{\circ},-104.707614^{\circ} \\
{[\sim 1 \mathrm{mi} \mathrm{NE} \text { of } 5686]}\end{array}$ & W.T. Lee, 1910 & 74,129 & $9,45,50,57$ \\
\hline 5689 & $\begin{array}{l}\text { N wall of Apishapa Canyon, } \\
31 \frac{1}{2} \text { mi SW of Aguilar or NE } \\
\text { of Abeton, CO }\end{array}$ & $\begin{array}{l}37.363019^{\circ},-104.700464^{\circ} \\
{[1 \mathrm{mi} \mathrm{NE} \text { of } 5688]}\end{array}$ & W.T. Lee, 1910 & $74,76,99,100$ & $9,45,50,57$ \\
\hline 5690 & $\begin{array}{l}\text { Delagua Mine dump, } \\
\text { W of Hastings, CO }\end{array}$ & $37.360523^{\circ},-104.650159^{\circ}$ & W.T. Lee, 1910 & $70,79,82,84,99,129,132$ & $9,45,50,56,57$ \\
\hline 5693 & Near Suffield Mine, CO & $37.258254^{\circ},-104.516028^{\circ}$ & Missing Data & 74 & 45,50 \\
\hline 5696 & $\begin{array}{l}11 \frac{1}{2} \mathrm{mi} \mathrm{SW} \text { of mine at Rugby, } \\
\sim 5 \mathrm{mi} \mathrm{N} \text { of Aguilar, } \mathrm{CO}\end{array}$ & $37.455457^{\circ},-104.687605^{\circ}$ & Missing Data & 79,132 & 45,50 \\
\hline 5697 & $\begin{array}{l}\text { Colorado Canyon, } \mathrm{W} \text { of } \\
\text { Trinidad, CO }\end{array}$ & $37.183419^{\circ},-104.564589^{\circ}$ & W.T. Lee, 1910 & $18,43,46,53,74,76,99,151$ & $9,45,50,57$ \\
\hline \begin{tabular}{c|}
5699 \\
5702,5703
\end{tabular} & $\begin{array}{l}\text { Riley Canyon, } 1 / 2 \mathrm{mi} \mathrm{N} \text { of } \\
\text { Cokedale, } \mathrm{CO}\end{array}$ & $37.152950^{\circ},-104.622122^{\circ}$ & W.T. Lee, 1910 & $45,71,99$ & $9,45,50,57$ \\
\hline 5700 & $\begin{array}{l}\text { Riley Canyon, near } \\
\text { Cokedale, CO }\end{array}$ & $37.150425^{\circ},-104.625661^{\circ}$ & W.T. Lee, 1910 & 79 & $9,45,50,57$ \\
\hline 5701 & $\begin{array}{l}\text { Riley Canyon, near } \\
\text { Cokedale, CO }\end{array}$ & $37.155767^{\circ},-104.629564^{\circ}$ & W.T. Lee, 1910 & $45,79,132,141,152$ & $9,45,50,57$ \\
\hline $\begin{array}{l}5704 \\
5795\end{array}$ & $\begin{array}{l}\text { W of Long Canyon, S wall of } \\
\text { Purgatoire Canyon, mouth of } \\
\text { Riley Canyon, S of } \\
\text { Cokedale, CO }\end{array}$ & $37.127205^{\circ},-104.607152^{\circ}$ & W.T. Lee, 1910 & $45,86,99,147$ & $9,45,50,57$ \\
\hline 5711 & $\begin{array}{l}\text { RR cut, } 1 / 2 \mathrm{mi} \text { N of Wootton, } \\
\text { CO }\end{array}$ & $37.007314^{\circ},-104.489303^{\circ}$ & W.T. Lee, 1910 & $\begin{array}{l}51,53,70,72-74,79,84,127, \\
132,151\end{array}$ & $9,25,45,50,57$ \\
\hline 5712 & $\begin{array}{l}\text { Hillside } \mathrm{W} \text { of Wootton, between } \\
\text { town and } \mathrm{N} \text { end of Raton } \\
\text { Tunnel, CO }\end{array}$ & $36.997231^{\circ},-104.490958^{\circ}$ & W.T. Lee, 1910 & $\begin{array}{l}45,51,53,59,70,74,79,82,86 \\
99,104,129,132,147,151\end{array}$ & $9,45,50,57$ \\
\hline 5713 & $\begin{array}{l}\text { RR cut, } 165 \mathrm{ft} \mathrm{N} \text { of } 5711, \mathrm{~N} \\
\text { of Wootton, } \mathrm{CO}\end{array}$ & $37.008356^{\circ},-104.488633^{\circ}$ & W.T. Lee, 1910 & 79 & $9,45,50,57$ \\
\hline 5714 & $\begin{array}{l}\text { Turner Mine dump, } 1 \frac{1}{2} \mathrm{mi} \mathrm{N} \text { of } \\
\text { Wooten, CO }\end{array}$ & $37.026603^{\circ},-104.480669^{\circ}$ & W.T. Lee, 1910 & $53,76,82,99,109,117,126,132,151$ & $9,45,50,57$ \\
\hline 5715 & RR cut, $1 \mathrm{mi} \mathrm{S}$ of Morley, CO & $37.019765^{\circ},-104.496606^{\circ}$ & W.T. Lee, 1910 & 79 & $9,45,50,57$ \\
\hline 5716 & $\begin{array}{l}14 \mathrm{mi} \text { E of Douglas, } 2 \mathrm{mi} \mathrm{N} \\
\text { of jct of western and middle } \\
\text { forks of Shawnee Cr., WY }\end{array}$ & $42.677685^{\circ},-105.142530^{\circ}$ & D.E. Winchester, July 29, 1910 & $33,35,96,144$ & $9,57,76$ \\
\hline 5718 & $\begin{array}{l}\text { Roof of prospect } \sim 2 \mathrm{mi} \mathrm{W} \\
\text { of Douglas, WY }\end{array}$ & $42.766592^{\circ},-105.415125^{\circ *}$ & D.E. Winchester, 21 July 1910 & 131 & 9,57 \\
\hline 5720 & $\begin{array}{l}\sim 1 \mathrm{mi} \text { NW of Sunset Mine, } \\
\sim 9.5 \text { miles N NW of Lost } \\
\text { Springs, WY }\end{array}$ & $42.892106^{\circ},-104.999436^{\circ}$ & D.E. Winchester, Aug. 20, 1910 & $85,87,146$ & $9,57,76$ \\
\hline 5721 & $\begin{array}{l}40 \mathrm{ft} \text { above coal, at Sunset } \\
\text { Mine, WY }\end{array}$ & $42.883756^{\circ},-104.982317^{\circ}$ & F.H. Knowlton, Aug. 20, 1910 & $29,32,79,122$ & $9,57,76$ \\
\hline $\begin{array}{l}5738 \\
8656\end{array}$ & $\begin{array}{l}\text { Top of a conical hill, } 3 / 4 \mathrm{mi} \mathrm{S} \\
\text { of a dry hole, } 6 \mathrm{mi} \mathrm{NW} \\
\text { of Ramah, } \mathrm{CO}\end{array}$ & $39.218014^{\circ},-104.222611^{\circ}$ & C.W. Cook, Sept. 7, 1910 & $4,14,15,18,19,83,109,132,141$ & 9,57 \\
\hline 5760 & $\begin{array}{l}1 \frac{1}{2} \text { mi E of Old Washakie } \\
\text { Station, N side of Muddy Cr., } \\
\text { WY }\end{array}$ & $41.480217^{\circ},-107.664147^{\circ}$ & A.C. Peale, Aug. 5,1910 & $72,104,151$ & $1,9,57$ \\
\hline 5783 & Near Rockville and Coal Cr, CO & $\begin{array}{l}38.3631833^{\circ},-105.1577333^{\circ} * \\
\text { [vicinity of secs. } 24,25,36, \text { T. } 19 \mathrm{~S} \text {, } \\
\text { R. } 70 \mathrm{~W} \text {, and secs. } 19,30,31, \\
\text { T. } 19 \text { S, R. } 69 \text { W] }\end{array}$ & W.T. Lee, 1910 & 132 & $9,57,73$ \\
\hline $\begin{array}{l}5796 \\
5797\end{array}$ & $\begin{array}{l}\text { RR cut, } 1 \frac{1}{2} \text { mi S of Starkville, } \\
\text { CO }\end{array}$ & $37.099264^{\circ},-104.524708^{\circ}$ & W.T. Lee, 1910 & 71 & $9,45,50,57$ \\
\hline 5798 & Rock dump, Primero Mine, CO & $37.142424^{\circ},-104.741093^{\circ}$ & W.T. Lee, 1910 & $10,53,79,82,99,122,152$ & $9,45,50,57$ \\
\hline
\end{tabular}




\begin{tabular}{|c|c|c|c|c|c|}
\hline $\begin{array}{l}\text { Locality } \\
\text { number }\end{array}$ & Brief Description & \begin{tabular}{|c|} 
Latitude, Longitude \\
[and original coordinates]
\end{tabular} & Collectors, Date & Taxon list & Reference \\
\hline $\begin{array}{l}5799 \\
5825\end{array}$ & $\begin{array}{l}\text { Wet Canyon, } \sim 4-5 \mathrm{mi} \mathrm{NW} \text { of } \\
\text { Weston, CO }\end{array}$ & $37.191406^{\circ},-104.883288^{\circ}$ & W.T. Lee, 1910 & $\begin{array}{l}70,74,83,86,97,99,100,109 \\
117,126\end{array}$ & $9,45,50,57$ \\
\hline 5801 & $\begin{array}{l}\text { N of North Fork of } \\
\text { Purgatoire R., CO }\end{array}$ & $37.212814^{\circ},-105.004225^{\circ}$ & Missing Data & 99 & 45,50 \\
\hline 5802 & $\begin{array}{l}400 \mathrm{ft} \text { above } 5803, \\
\text { near Terclo, CO }\end{array}$ & $37.066547^{\circ},-104.984419^{\circ}$ & W.T. Lee, 1910 & $53,79,132,151$ & $9,45,50,57$ \\
\hline 5803 & near Terclo, $\mathrm{CO}$ & $37.065397^{\circ},-104.983967^{\circ}$ & W.T. Lee, 1910 & \begin{tabular}{|l|}
$13,43,86,99$ \\
\end{tabular} & $9,45,50,57$ \\
\hline 5826 & $\begin{array}{l}\text { Vermejo Cr., Vermejo Canyon, } \\
5 \text { mi above Stout Canyon, } \\
\text { near Salyers Cr., NM }\end{array}$ & $36.771915^{\circ},-104.844568^{\circ}$ & W.T. Lee, 1910 & $\begin{array}{l}7,8,45,46,71,74,78,79,82-84 \\
86,96,97,99,126,129,132\end{array}$ & $9,45,50,57$ \\
\hline 5827 & $\begin{array}{l}\text { Vermejo Cr. Canyon, 3-4 mi } \\
\text { NW of Dawson, near } \\
\text { Stout Canyon, NM }\end{array}$ & $36.711403^{\circ},-104.800531^{\circ}$ & W.T. Lee, 1910 & 45,71 & $9,45,50,57,59$ \\
\hline 5830 & $\begin{array}{l}\text { NW of Ute Park, in canyon } \\
\text { on wagon rd from Ute Park } \\
\text { to Ponil Cr., NM }\end{array}$ & $36.606889^{\circ},-105.127267^{\circ}$ & W.T. Lee, 1910 & $45,74,82$ & $9,50,57$ \\
\hline 5831 & $\begin{array}{l}\text { E bank of Jimmy Camp Cr., } \\
\text { 6/10 mi N of Richfield Springs } \\
\text { Ranch, } 9 \text { mi E of Colorado } \\
\text { Springs, CO }\end{array}$ & $38.853028^{\circ},-104.659820^{\circ}$ & $\begin{array}{l}\text { F.H. Knowlton \& W.T. Lee, } \\
\text { July } 11,1910\end{array}$ & $\begin{array}{l}15,71,74,81,92,127 ?, 132 ?, \\
138,165\end{array}$ & $9,27,57,64$ \\
\hline 5835 & $\begin{array}{l}1 \text { mi E of Richfield Springs } \\
\text { Ranch on E bank of Jimmy } \\
\text { Camp Cr., } 9 \text { mi E of Colorado } \\
\text { Springs, CO }\end{array}$ & $38.855193^{\circ},-104.653664^{\circ}$ & F.H. Knowlton, July 11,1910 & $79,81,132$ & $9,27,57,64$ \\
\hline $\begin{array}{l}5836 \\
8655\end{array}$ & $\begin{array}{l}\text { RR cut } 3 / 4 \text { mi SW of Falcon, } \\
10 \text { mi } \mathrm{SW} \text { of Eastonville, } \mathrm{CO}\end{array}$ & $38.927467^{\circ},-104.618306^{\circ}$ & $\begin{array}{l}\text { F.H. Knowlton \& G.B. } \\
\text { Richardson, July 22, } 1910\end{array}$ & $12,18,32,51,59,109,132$ & $9,27,57,63,64$ \\
\hline 5837 & $\begin{array}{l}\text { Gulch just S of Rice's clay } \\
\text { bank, } 1 \text { mi SW of Calhan, CO }\end{array}$ & $39.023518^{\circ},-104.305727^{\circ}$ & $\begin{array}{l}\text { F.H. Knowlton, Wood \& C.W. } \\
\text { Cooke, July 26, } 1910\end{array}$ & $\begin{array}{l}74,99,127,131,132,136 \\
147,165\end{array}$ & $9,27,57,63,64$ \\
\hline 5838 & $\begin{array}{l}\text { Dump of Mosby coal mine, } \\
\text { Mosby, CO }\end{array}$ & $38.917983^{\circ},-104.377647^{\circ}$ & Missing Data & $6,22,109,126,132,147$ & 9,65 \\
\hline 5839 & $1 / 4 \mathrm{mi}$ E of Purdons Mine, CO & $39.064878^{\circ},-104.208040^{\circ}$ & $\begin{array}{l}\text { G.B. Richardson, C.W. Cooke, } \\
\text { \& Wood, Aug. } 1910\end{array}$ & $59,72,100,122,132,138$ & $9,47,53,57$ \\
\hline 5840 & Red Hill, 4 mi S of Ramah, CO & $39.068939^{\circ},-104.165939^{\circ}$ & Missing Data & $19,43,46,74,96,131,136,141$ & $9,47,49$ \\
\hline 5842 & $16 \mathrm{mi} \mathrm{SW}$ of Baker, MT & $46.222706^{\circ},-104.417981^{\circ}$ & M.A. Peale, Aug. 12, 1910 & 14 & $9,5,57$ \\
\hline 5863 & Near Belle Fourche R, WY & $44.066133^{\circ},-105.272408^{\circ}$ & J.J. Galloway, July 15,1910 & 126 & 9,57 \\
\hline 5882 & O'Fallon Cr., E of Terry, MT & $46.753128^{\circ},-105.123100^{\circ}$ & \begin{tabular}{|l|} 
J.R. Newby, L.E. Trout, F.A. \\
Herald, July 29, 1910 \\
\end{tabular} & 153 & $9,31,57$ \\
\hline 5885 & near Terry, MT & $\begin{array}{l}46.624678^{\circ},-104.377811^{\circ} \\
{[\mathrm{NE} 1 / 4, \text { Sec. } 14, \text { T. } 10 \text { N, R. } 58 \text { E] }} \\
\end{array}$ & J.R. Newby, Aug. 26, 1910 & $67,104,154$ & $9,31,57$ \\
\hline 5886 & $0.8 \mathrm{mi}$ S of Cap Rock Road, MT & $\begin{array}{l}46.622975^{\circ},-104.318008^{\circ} \\
{\left[\mathrm{NE}^{1 / 4} \text { Sec. } 17, \text { T. } 10 \text { N, R. } 59 \mathrm{E}\right]} \\
\end{array}$ & $\begin{array}{l}\text { F.A. Herald, J.R.H. \& J.R. } \\
\text { Newby, Sept. 2, } 1910\end{array}$ & 31,46 & $9,31,57$ \\
\hline 5889 & near Terry, MT & $\begin{array}{l}46.669511^{\circ},-104.322814^{\circ} \\
{[N W 1 / 4 \mathrm{NE} 1 / 4, \text { Sec. } 32, \text { T. } 11 \mathrm{~N},} \\
\text { R. } 59 \mathrm{~W}]\end{array}$ & $\begin{array}{l}\text { J.R. Newby, J.R.H., } \\
\text { Sept. 5, } 1910\end{array}$ & 104,154 & $9,31,57$ \\
\hline 5905 & $2.3 \mathrm{mi}$ S SW of Weston, WY & $\begin{array}{l}44.603212^{\circ},-105.357441^{\circ} \\
{[\text { Sec. 2, T. } 53 \mathrm{~N}, \text { R. } 71 \mathrm{~W}]}\end{array}$ & Missing Data & 51,57 & 9,16 \\
\hline 5911 & $\sim 22 \mathrm{mi} \mathrm{N}$ of Kaycee, $\mathrm{WY}$ & $\begin{array}{l}44.013133^{\circ},-106.613104^{\circ} \\
{[\text { Sec. } 29, \text { T. } 47 \mathrm{~N}, \text { R. } 81 \mathrm{~W}]}\end{array}$ & C.H. Wegemann, July 19, 1910 & 28 & 9,75 \\
\hline $\begin{array}{l}5917, \\
5918\end{array}$ & S of Sussex, WY & {$[$ T. $42 \mathrm{~N}, \mathrm{R} .78 \mathrm{~W}]$} & \begin{tabular}{|l} 
O.B. Hopkins for C.H. \\
Wegemann, Aug. 24, 1910
\end{tabular} & $52,114,164,168$ & 9,75 \\
\hline 5971 & Ferris Formation, southern, WY & $?$ & Missing Data & 147 & 9 \\
\hline 6050 & $\begin{array}{l}6 \text { mi SW of Moorcroft, Belle } \\
\text { Fourche, WY }\end{array}$ & $44.236578^{\circ},-105.080136^{\circ}$ & V.H. Barnett, June 14, 1911 & 154 & $9,18,57$ \\
\hline 6051 & $6 \mathrm{mi} \mathrm{W}$ of Moorcroft, WY & $44.254347^{\circ},-105.066475^{\circ}$ & V.H. Barnett, June 14, 1911 & 45 & $9,18,57$ \\
\hline 6057 & $30 \mathrm{mi}$ SW of Moorcroft, WY & $43.969367^{\circ},-105.207336^{\circ}$ & $\begin{array}{l}\text { A.W.S. \& V.H. Barnett, R.P., } \\
\text { July } 24,1911\end{array}$ & $74,79,85,87$ & 9,57 \\
\hline 6083 & $45 \mathrm{mi} \mathrm{S}$ of Moorcroft, WY & $43.857883^{\circ},-105.168642^{\circ}$ & V.H. Barnett, Aug. 3, 1911 & 87 & $9,18,57$ \\
\hline 6084 & $\begin{array}{l}20 \text { mi above Hampshire, WY, } \\
\text { on Little Thunder Cr. }\end{array}$ & $43.648969^{\circ},-104.889286^{\circ}$ & V.H. Barnett, Sept. 9, 1911 & 9,18 & 9,57 \\
\hline 6113 & Near head of Wolf Draw, SD & $45.418531^{\circ},-102.951194^{\circ}$ & D.E. Winchester, July 8,1911 & 79 & $9,57,77$ \\
\hline 6114 & $3.4 \mathrm{mi} \mathrm{S}$ of Strool, SD & $\begin{array}{l}45.451326^{\circ},-102.819197^{\circ} \\
{[\text { Sec. } 7, \text { T. } 17 \text { N, R. } 11 \mathrm{E}]}\end{array}$ & Missing Data & Missing Data & 9 \\
\hline 6116 & Sexton Mine, SD & $\begin{array}{l}45.437194^{\circ},-102.549275^{\circ} \\
{[\text { Sec. } 17, \text { T. } 17 \mathrm{~N}, \text { R. } 13 \mathrm{E}]}\end{array}$ & Missing Data & $1,15,122$ & 9,77 \\
\hline 6117 & $10.5 \mathrm{mi}$ S of Lemmon, SD & $\begin{array}{l}45.781095^{\circ},-102.160769^{\circ *} \\
{[\text { Sec. } 17, \text { T. } 21 \mathrm{~N}, \text { R. } 16 \mathrm{E},}\end{array}$ & $\begin{array}{l}\text { C.B.A., D.E. Winchester, } \\
\text { Oct. } 9,1911\end{array}$ & $72,96,104$ & $9,57,77$ \\
\hline 6131 & $\begin{array}{l}1 \mathrm{mi} \text { N of R.R. bridge, } \\
\text { near Terry, MT }\end{array}$ & $46.785778^{\circ},-105.455761^{\circ}$ & G.S. Rogers party, July 8,1911 & 96 & 9,57 \\
\hline 6142 & $\begin{array}{l}\sim 2^{1 / 4} \text { miles SE of Monument, } \\
\mathrm{CO}, 2 \mathrm{mi} \text { E of } \mathrm{RR}\end{array}$ & $39.077089^{\circ},-104.825614^{\circ}$ & C.W. Cooke, Sept. 9, 1911 & $8,15,79 ?, 136$ & $9,57,64$ \\
\hline 6145 & $\begin{array}{l}\text { Coal Cr., } 18 \text { mi E of Denver, } \\
\text { Castle Rock Quad., CO }\end{array}$ & $39.693069^{\circ},-104.681247^{\circ *}$ & J.B. Richardson, Oct. 1911 & 126 & 9,57 \\
\hline 6154 & $7.5 \mathrm{mi} \mathrm{SW}$ of Reva, SD & $\begin{array}{l}45.466754^{\circ},-103.201928^{\circ} \\
{[\text { Sec. } 1, \text { T. } 17 \text { N, R. } 7 \text { E] }}\end{array}$ & E.M. Parks \& party, Aug. 23, 1911 & $32,39,69,95,96,131$ & $9,57,77$ \\
\hline 6155 & $\sim 7.9 \mathrm{mi}$ SE of Reva, SD & $\begin{array}{l}45.465906^{\circ},-102.961094^{\circ} \\
\text { [ctr. Sec. 1, T. } 17 \text { N, R. } 9 \text { E] }\end{array}$ & Missing Data & Missing Data & 9 \\
\hline 6156 & $\sim 8.6 \mathrm{mi}$ SW of Reva, SD & $\begin{array}{l}45.449869^{\circ},-103.208381^{\circ} \\
{\left[N E 1 / 4 S^{1} 1 / 4, \text { Sec. } 12, \text { T. } 17 \text { N, }\right.} \\
\text { R. } 7 \text { E] }\end{array}$ & $\begin{array}{l}\text { E.M. Parks \& party, } \\
\text { Aug. } 19,1911\end{array}$ & $32,39,104$ & $9,57,77$ \\
\hline 6161 & $7 \mathrm{mi} \mathrm{NW}$ of Reva, SD & $\begin{array}{l}45.580689^{\circ},-103.214264^{\circ} \\
{[\text { Sec. } 25, \text { T. } 19 \text { N, R. 7E] }}\end{array}$ & $\begin{array}{l}\text { E.M. Parks \& party, } \\
\text { Sept. } 6,1911\end{array}$ & 104 & $9,57,77$ \\
\hline
\end{tabular}




\begin{tabular}{|c|c|c|c|c|c|}
\hline $\begin{array}{l}\text { Locality } \\
\text { number }\end{array}$ & Brief Description & $\begin{array}{c}\text { Latitude, Longitude } \\
\text { [and original coordinates] }\end{array}$ & Collectors, Date & Taxon list & Reference \\
\hline 6171 & $19.5 \mathrm{mi} \mathrm{SE}$ of Cody, WY & $\begin{array}{l}44.295328^{\circ},-108.825358^{\circ} \\
{[N 1 / 2 \text { Sec. } 24, \text { T. } 50 \mathrm{~N},} \\
\text { R. } 100 \text { W.] }\end{array}$ & D.T. Hewett, July 20, 1911 & 61 & $9,35,36,57$ \\
\hline 6173 & $\begin{array}{l}\text { Above stage rd opposite } \\
\text { Sleepers Ranch, WY }\end{array}$ & $44.262561^{\circ},-108.799375^{\circ}$ & D.T. Hewett, Aug. 2, 1911 & $6,32,33,104$ & $9,35,36,57$ \\
\hline 6176 & $23.5 \mathrm{mi}$ SE of Cody, WY & $\begin{array}{l}44.243714^{\circ},-108.797644^{\circ} \\
{[\text { SE } 1 / 4 \text { Sec. } 6, \text { T. } 49 \text { N, R. } 99 \mathrm{~W}]}\end{array}$ & D.T. Hewett, Aug. 91911 & 33 & $9,36,57$ \\
\hline 6215 & $\begin{array}{l}\text { On Little Missouri R. S. of } \\
\text { Yule, ND }\end{array}$ & $46.549411^{\circ},-103.807272^{\circ}$ & $\begin{array}{l}\text { Mr. Bauer for C.J. Hares, } \\
\text { July } 10,1911\end{array}$ & $25,142 ?, 175$ & $9,28,57$ \\
\hline 6219 & $\begin{array}{l}\text { W of Little Missouri R., N } \\
\text { of mouth of Bullion Cr., } \\
14 \text { mi S of Andiru, ND }\end{array}$ & $46.710717^{\circ},-103.599233^{\circ}$ & $\begin{array}{l}\text { Bauer \& Birch for C.J. Hares, } \\
27 \text { July } 1911\end{array}$ & 29,32 & $9,28,38,57$ \\
\hline 6225 & $\begin{array}{l}20 \mathrm{mi} \text { NE of Marmarth, } 8 \mathrm{mi} \mathrm{S} \\
\text { of Dakota National Forest, ND }\end{array}$ & $46.431189^{\circ},-103.546142^{\circ}$ & Price \& Birch, Sept. 9, 1911 & $67,69,122,145$ & $9,28,57$ \\
\hline 6297 & $\sim 3 \mathrm{mi} \mathrm{N}$ of Craig, $\mathrm{CO}$ & $40.549039^{\circ},-107.534306^{\circ *}$ & W.T. Lee, 1912 & 79,132 & 9,57 \\
\hline 6299 & $\begin{array}{l}1 \mathrm{mi} \mathrm{S} \text { of Ducey's ranch, } 7 \mathrm{mi} \\
\text { NW of Craig, CO }\end{array}$ & $40.564119^{\circ},-107.620953^{\circ *}$ & W.T. Lee, 1912 & 51 & 9,57 \\
\hline 6309 & $\begin{array}{l}\text { RR cut } 1 / 2 \text { mi downstream } \\
\text { from station at Pagosa } \\
\text { Junction, } C O\end{array}$ & $37.034225^{\circ},-107.205308^{\circ}$ & W.T. Lee, 1912 & $90,97,129,132,156$ & $9,48,50,57$ \\
\hline $\begin{array}{l}6342 \\
8885\end{array}$ & $\begin{array}{l}\text { Mackton Coal Mine, 6-7 mi } \\
\text { NE of Big Sandy, MT }\end{array}$ & $48.182206^{\circ},-109.985564^{\circ}$ & & 54,158 & $6,9,57,58$ \\
\hline 6344 & $2 \mathrm{mi}$ SW of Inez, WY & $42.819394^{\circ},-105.609370^{\circ}$ & V.H. Barnett, Sept. 24, 1912 & 59,79 & $2,9,57$ \\
\hline 6359 & 13.7 mi SE of Cody, WY & $\begin{array}{l}44.392961^{\circ},-108.846058^{\circ} \\
\text { [Near ctr. Sec. 14, T. } 51 \mathrm{~N}, \\
\text { R. } 100 \mathrm{~W} \text { ] }\end{array}$ & $\begin{array}{l}\text { D.F. Hewett \& T.W. Stanton, } \\
\text { Sept. } 4,1912\end{array}$ & $32,36 ?, 96,131$ & $9,36,57$ \\
\hline 6360 & $19.5 \mathrm{mi}$ SE of Cody, WY & $\begin{array}{l}44.292264^{\circ},-108.830328^{\circ} \\
{[200 \mathrm{ft} \mathrm{NW} \text { of ctr. of Sec. } 24,} \\
\text { T. } 50 \mathrm{~N}, \mathrm{R} .100 \mathrm{~W}]\end{array}$ & $\begin{array}{l}\text { D.F. Hewett \& T.W. Stanton, } \\
\text { Sept. 6, } 1912\end{array}$ & 142 & $9,35,36,57$ \\
\hline 6376 & $10 \mathrm{mi} \mathrm{S}$ of Bentley, ND & $46.206114^{\circ},-102.066700^{\circ}$ & $\begin{array}{l}\text { E.R. Lloyd \& B.W. Clark, } \\
\text { Aug. 24, } 1912\end{array}$ & $40 \mathrm{a}$ & $9,54,57$ \\
\hline 6377 & $1 \mathrm{mi}$ S of Kaiser, ND & $46.364261^{\circ},-101.788257^{\circ}$ & $\begin{array}{l}\text { W.T. Thorn \& L.M. Newman, } \\
\text { Sept., } 1912\end{array}$ & 153 & $9,38,54,57$ \\
\hline 6382 & $3 \mathrm{mi}$ E of Scranton, ND & $46.125413^{\circ},-103.099307^{\circ}$ & $\begin{array}{l}\text { C.J. Hares \& E.G. Woodruff, } \\
\text { July, } 1912\end{array}$ & 176 & 9,57 \\
\hline $\begin{array}{l}6384 \\
9125\end{array}$ & $\begin{array}{l}\text { Opposite Anarchist Butte } \\
\text { on Hwy, SD }\end{array}$ & $45.833081^{\circ},-103.002106^{\circ}$ & $\begin{array}{l}\text { R.W. Brown, N Denson \& } \\
\text { W. Benson, } 8 \text { July } 1950\end{array}$ & $\begin{array}{l}3,29,32,34,37,78,79,96 \\
156,164,174,178,195\end{array}$ & 9,77 \\
\hline 6415 & Ferris Formation, SE WY & $?$ & Missing Data & 96 & 9 \\
\hline 6416 & bank of Big Ditch, WY & $\begin{array}{l}41.948829^{\circ},-106.828454^{\circ} \\
{\left[N W 1 / 4 \mathrm{SW}^{1 / 4}, \operatorname{Sec} .24, \text { T. } 23 \mathrm{~N},\right.} \\
\text { R. } 84 \mathrm{~W}]\end{array}$ & A.L. Buckly, Sept., 1912 & 132 & 9,70 \\
\hline 6417 & N bank of Big Ditch, WY & $\begin{array}{l}41.942305,-106.830966^{\circ} \\
{[\mathrm{SE} 1 / 4 \mathrm{SE} 1 / 4, \operatorname{Sec} .23, \text { T. } 23 \mathrm{~N},} \\
\text { R. } 84 \mathrm{~W}]\end{array}$ & A.L. Buckly, Sept., 1912 & $40 a, 79$ & $9,57,70$ \\
\hline 6419 & bank of Big Ditch, WY & $\begin{array}{l}41.931434^{\circ},-106.844280^{\circ} \\
{\left[N W 1 / 4 \mathrm{SW}^{1 / 4}, \mathrm{Sec} .26, \text { T. } 23 \mathrm{~N},\right.} \\
\text { R. } 84 \mathrm{~W}]\end{array}$ & A.L. Buckly, Sept., 1912 & 14 & $9,57,70$ \\
\hline 6420 & $10.7 \mathrm{mi} \mathrm{W}$ of Hanna, WY & $\begin{array}{l}41.882625^{\circ},-106.767319^{\circ} \\
{[\mathrm{NW} 1 / 4 \mathrm{NW} 1 / 4, \text { Sec. } 16, \text { T. } 22 \mathrm{~N},} \\
\text { R. } 83 \mathrm{~W}]\end{array}$ & A.L. Buckly, Sept., 1912 & $16,36,96,144$ & $9,57,70$ \\
\hline 6428 & $\begin{array}{l}\text { Southern arm of Seminoe } \\
\text { Reservoir, WY }\end{array}$ & $\begin{array}{l}41.973672^{\circ},-106.840467^{\circ} \\
{\left[\mathrm{SE}^{1 / 4} \mathrm{SW} 1 / 4, \mathrm{Sec} .11, \text { T. } 23 \mathrm{~N},\right.} \\
\text { R. } 84 \mathrm{~W}]\end{array}$ & A.L. Buckly, Oct. 14, 1912 & 59 & $9,57,70$ \\
\hline 6431 & N of Platte R., WY & $\begin{array}{l}41.936636^{\circ},-106.855497^{\circ} \\
{[\text { SW 1/4 NE 1/4, Sec. 27, T. } 23 \mathrm{~N},} \\
\text { R. } 84 \mathrm{~W}]\end{array}$ & A.L. Buckly, Oct. 16, 1912 & $87,126,132$ & $9,57,70$ \\
\hline 6443 & 1 mi NE of Pagosa Junction, CO & $37.041306^{\circ},-107.186047^{\circ *}$ & W.T. Lee, 1912 & $45,74,79,85,132$ & $9,24,50,57$ \\
\hline 6444 & $\begin{array}{l}1 \text { mi. NW of Pagosa Junction, } \\
\text { CO }\end{array}$ & $37.042720^{\circ},-107.208311^{\circ *}$ & W.T. Lee, 1912 & $45,74,79,126,90$ & $9,24,50$ \\
\hline 6530 & $\begin{array}{l}\text { At foot of Barilla Mesa, in E } \\
\text { wall of Sugarite Cayon, in roof } \\
\text { of new Sugarite Mine, NM }\end{array}$ & $36.947419^{\circ},-104.380389^{\circ}$ & Missing Data & 99,141 & 50 \\
\hline 6535 & Van Houten, Raton Field, NM & $36.794656^{\circ},-104.563236^{\circ *}$ & W.F. Lee, 1913 & 79,97 & 9,57 \\
\hline 6592 & $21 \mathrm{mi} \mathrm{W} \mathrm{NW}$ of Craig, CO & $\begin{array}{l}40.587342^{\circ},-107.950344^{\circ *} \\
{[\text { Sec. } 4, \text { T. } 7 \text { N, R. } 94 \text { W] }}\end{array}$ & Missing Data & 50 & 9,57 \\
\hline 6594 & $20.4 \mathrm{mi} \mathrm{W}$ NW of Craig, CO & $\begin{array}{l}40.593178^{\circ},-107.916558^{\circ *} \\
{[\mathrm{~N} 1 / 2 \text { Sec. } 2, \text { T. } 7 \text { N, R. } 94 \mathrm{~W}]}\end{array}$ & Missing Data & 55 & 9 \\
\hline 6598 & $\begin{array}{l}\sim 6 \mathrm{mi} \mathrm{S} \text { of St. Gertrude, ND, } \\
1.5 \mathrm{mi} \text { E of hwy } 31\end{array}$ & $\begin{array}{l}46.194639^{\circ},-101.304403^{\circ} \\
{[\mathrm{SW} 1 / 4, \text { Sec. } 3, \text { T. } 131 \text { N, R. } 85 \mathrm{~W}]}\end{array}$ & L.M. Neumann, July 31, 1913 & 75,104 & 9,57 \\
\hline 6602 & $1 \mathrm{mi}$ SE of Leith, ND & $46.337381^{\circ},-101.617622^{\circ}$ & Missing Data & 63 & 9,54 \\
\hline 6625 & $\sim 11.75 \mathrm{mi}$ W NW of Hanna, WY & $\begin{array}{l}41.931628^{\circ},-106.775847^{\circ} \\
{\left[\mathrm{SE}^{1 / 4} \text { Sec. } 29, \text { T. } 23 \text { N, R. } 83 \mathrm{~W}\right]}\end{array}$ & C.F. Bowen, Aug. 15, 1913 & 51,79 & $9,57,70$ \\
\hline 6630 & $\sim 13.65 \mathrm{mi} \mathrm{W}$ NW of Hanna, WY & $\begin{array}{l}41.896833^{\circ},-106.822317^{\circ} \\
{[N E 1 / 4 \mathrm{NW} 1 / 4, \text { Sec. } 12, \text { T. } 22 \mathrm{~N},} \\
\text { R. } 84 \mathrm{~W}]\end{array}$ & Missing Data & 72 & 9,70 \\
\hline 6652 & $3 \mathrm{mi} \mathrm{S}$ of Old Strain, ND & $46.570183^{\circ},-101.033517^{\circ}$ & $\begin{array}{l}\text { Neumann \& Mansfield, } \\
\text { Sept. } 2,1913\end{array}$ & $40 \mathrm{a}$ & 9,57 \\
\hline 6667 & $\mathrm{~N}$ of Ilo PO, WY & $\begin{array}{l}43.925739^{\circ},-108.516606^{\circ} \\
{\left[E^{1} / 2, \text { Sec. } 29, \text { T. } 46 \text { N, R. } 97 \text { W] }\right.}\end{array}$ & D.F. Hewett, Oct. 3, 1913 & $40,89,95$ & $9,35,46,57$ \\
\hline 6668 & $\mathrm{~N}$ of Ilo PO, WY & $\begin{array}{l}43.927644^{\circ},-108.507022^{\circ} \\
{[N W 1 / 4, \text { Sec. } 28, \text { T. } 46 \text { N, R. } 97 \text { W] }}\end{array}$ & D.F. Hewett, Oct. 3, 1913 & 72,156 & 9,35 \\
\hline
\end{tabular}




\begin{tabular}{|c|c|c|c|c|c|}
\hline $\begin{array}{l}\text { Locality } \\
\text { number }\end{array}$ & Brief Description & \begin{tabular}{|c|} 
Latitude, Longitude \\
[and original coordinates]
\end{tabular} & Collectors, Date & Taxon list & Reference \\
\hline 6669 & Near Ilo PO, WY & $\begin{array}{l}43.910731^{\circ},-108.502750^{\circ} \\
{[\mathrm{W} 1 / 2, \text { Sec. } 33, \text { T. } 46 \text { N, R. } 97 \mathrm{~W}]}\end{array}$ & D.F. Hewett, Oct. 3, 1913 & 95 & 9,35 \\
\hline 6738 & $\sim 12$ mi N of Glenrock, WY & $43.017206^{\circ},-105.864278^{\circ}$ & V.H. Barnett, 1913 & $31,51,52$ & 9,57 \\
\hline 6765 & $\begin{array}{l}\text { First cut on RR, } 3 / 4 \mathrm{mi} \mathrm{S} \text { of } \\
\text { Wilsall, near milepost } 22, \mathrm{~N} \text { of } \\
\text { Livingston, MT }\end{array}$ & $45.984250^{\circ},-110.655325^{\circ}$ & $\begin{array}{l}\text { F.H. Knowlton \& E.W. Berry, } \\
\text { 1913; R.W. Brown, C.E.S., } \\
\text { July } 17,1940\end{array}$ & $29,32,58,98,145,191$ & 9,57 \\
\hline 6767 & $\begin{array}{l}\text { Brackett Cr., } 1 / 4 \mathrm{mi} \mathrm{W} \text { of } \\
\text { National Forest Reserve, } \mathrm{N} \text { of } \\
\text { Livingston, } 12 \mathrm{mi} \mathrm{W} \text { of } \\
\text { Clyde Park, MT }\end{array}$ & $45.858525^{\circ},-110.860317^{\circ}$ & $\begin{array}{l}\text { E.W. Berry, T.W. Stanton \& } \\
\text { F.H. Knowlton, } 1913\end{array}$ & $29,32,34,57,86,131$ & 9,57 \\
\hline 6839 & $\begin{array}{l}\text { Conant Cr., about } 35 \mathrm{mi} \text { E of } \\
\text { Lander, WY }\end{array}$ & $42.882833^{\circ},-108.014084^{\circ}$ & J.B. Reeside, Jr., Aug. 28, 1914 & 56 & 9,57 \\
\hline 6845 & $\begin{array}{l}\text { Coal Cr., } 55 \text { mi NW of Rawlins, } \\
\text { WY }\end{array}$ & $42.324342^{\circ},-107.534808^{\circ}$ & C.J. Hares, Oct. 3, 1914 & 15 & 9,57 \\
\hline 6892 & $7.4 \mathrm{mi}$ E of New Salem, ND & $\begin{array}{l}46.851361^{\circ},-101.253922^{\circ} \\
{[S W 1 / 4 \text { Sec. } 14, \text { T. } 139 \mathrm{~N},} \\
\text { R. } 84 \mathrm{~W}]\end{array}$ & $\begin{array}{l}\text { E.J. Hancock \& G. Williams, } \\
\text { Oct. } 9,1914\end{array}$ & 139 & 9,57 \\
\hline 6905 & $6.5 \mathrm{mi} \mathrm{S}$ of New Salem, ND & $\begin{array}{l}46.751186^{\circ},-101.401678^{\circ} \\
{[S W 1 / 4 \text { Sec. } 22, \text { T. } 138 \mathrm{~N}} \\
\text { R. } 85 \text { W] }\end{array}$ & Missing Data & 188 & 9 \\
\hline 6943 & $1 / 2 \mathrm{mi} \mathrm{W}$ of Ramah, CO & $39.121674^{\circ},-104.174611^{\circ}$ & W.F. Lee, 1915 & 71 & 9,57 \\
\hline 6944 & $\begin{array}{l}\text { Coal Gulch, } 2 \text { mi NW of } \\
\text { Ramah, CO }\end{array}$ & $39.143133^{\circ},-104.182056^{\circ}$ & Missing Data & Missing Data & 9 \\
\hline 6971 & $\begin{array}{l}\text { Middle Perc cut, } 5 \text { mi E of } \\
\text { Dana, WY }\end{array}$ & $41.837619^{\circ},-106.631503^{\circ}$ & $\begin{array}{l}\text { T.W. Stanton \& C.F. Bowen, } \\
\text { July } 9,1915\end{array}$ & $32,51,72,79,85,96,104,156$ & $9,57,70$ \\
\hline 6985 & $\sim 9 \mathrm{mi}$ NE of Hanna, WY & \begin{tabular}{|l|}
$41.936883^{\circ},-106.412250^{\circ}$ \\
{$[\mathrm{NE} 1 / 4$ Sec. 28, T. $23 \mathrm{~N}$, R. $80 \mathrm{~W}]$}
\end{tabular} & C.F. Bowen, July 1915 & $40 \mathrm{a}, 63$ & 9 \\
\hline 7004 & $10.4 \mathrm{mi} \mathrm{N} \mathrm{NW}$ of Scobey, MT & $\begin{array}{l}48.924486^{\circ},-105.522031^{\circ} \\
{[\mathrm{NE} 1 / 4 \text { Sec. } 33, \text { T. } 37 \mathrm{~N}, \mathrm{R} .47 \mathrm{E}]}\end{array}$ & W.T. Thom, E.C., Aug. 30, 1915 & $14,25,30,38,104,143$ & 9,57 \\
\hline 7005 & 16.5 mi N NE of Scobey, MT & $49.006492^{\circ},-105.278181^{\circ}$ & A.J. Collier, Sept. 3, 1915 & $16,32,33,144$ & $9,12,57$ \\
\hline 7371 & 3 mi SW of Farmington, NM & $36.700034^{\circ},-108.254058^{\circ *}$ & $\begin{array}{l}\text { H. Bassler, J.B. Reeside, Jr., } \\
\text { July } 16,1917\end{array}$ & $70,74,79,127$ & $9,57,61$ \\
\hline 7452 & $1 \mathrm{mi}$ NW of Bayfield, CO & $37.233345^{\circ},-107.613652^{\circ}$ & J.B. Reeside, Jr., Oct. 271920 & 79 & 24,48 \\
\hline 7463 & $5 \mathrm{mi}$ E of Durango, $\mathrm{CO}$ & $37.275523^{\circ},-107.785853^{\circ}$ & J.B. Reeside, Jr., Oct. 8, 1920 & 79,127, & $9,24,48,57$ \\
\hline 7480 & $\begin{array}{l}600 \mathrm{ft} \text { above base, hill top } \mathrm{W} \text { of } \\
\text { Talian Mine, } 5 \mathrm{mi} \mathrm{N} \text { of Pagosa } \\
\text { Junction, } \mathrm{CO}\end{array}$ & $37.104932^{\circ},-107.186555^{\circ}$ & $\begin{array}{l}\text { Q.D. Singewald, J.B. Reeside, Jr., } \\
\text { May 31, } 1921\end{array}$ & $18,45,71,74,79,98,127$ & $9,24,48,57$ \\
\hline 7481 & $\begin{array}{l}\text { Loose sloop, hill top W of } \\
\text { Talian Mine, } 5 \mathrm{mi} \mathrm{N} \text { of } \\
\text { Pagosa Junction, } \mathrm{CO}\end{array}$ & $37.104932^{\circ},-107.186555^{\circ}$ & $\begin{array}{l}\text { Q.D. Singewald, J.B. Reeside, Jr., } \\
\text { June } 1,1921\end{array}$ & $19,45,71,74,98,99,127$ & $9,24,48,57$ \\
\hline 7482 & $\begin{array}{l}\text { Hill top W of Talian Mine, } \\
5 \mathrm{mi} \text { N of Pagosa Junction, CO }\end{array}$ & $37.104932^{\circ},-107.186555^{\circ}$ & $\begin{array}{l}\text { Q.D. Singewald \& J.B. Reeside, Jr., } \\
\text { June } 1921\end{array}$ & 79 & $9,24,48,57$ \\
\hline 7483 & $\begin{array}{l}1000 \mathrm{ft} \mathrm{S} \text { of Talian Mine, } 4 \frac{1}{2} \\
\mathrm{mi} \text { N of Pagosa Junction, CO }\end{array}$ & $37.102441^{\circ},-107.185056^{\circ}$ & $\begin{array}{l}\text { Q.D. Singewald \& J.B. Reeside, Jr., } \\
\text { June } 1,1921\end{array}$ & $71,75,135,141$ & $9,24,48,57$ \\
\hline 7484 & \begin{tabular}{|l|} 
On rd $1 / 2$ mi S of Talian Mine, \\
$4 \frac{1}{2}$ mi N of Pagosa Junction, CO
\end{tabular} & $37.098917^{\circ},-107.186600^{\circ}$ & $\begin{array}{l}\text { Q.D. Singewald \& J.B. Reeside, Jr., } \\
\text { June 2, } 1921\end{array}$ & 13 & $9,24,48,57$ \\
\hline 7485 & $\begin{array}{l}\text { On rd } 1 / 2 \text { mi S of Talian Mine, } \\
4 \frac{1}{2} \text { mi N of Pagosa Junction, CO }\end{array}$ & $37.101278^{\circ},-107.188883^{\circ}$ & $\begin{array}{l}\text { Q.D. Singewald \& J.B. Reeside, Jr., } \\
\text { June 2, } 1921\end{array}$ & $53,59,74,79,99,126,132$ & $9,24,48,57$ \\
\hline 7495 & $1 \mathrm{mi}$ NW of Ojo Alamo, NM & $36.337839^{\circ},-108.050356^{\circ}$ & $\begin{array}{l}\text { Wells, Q.D.Singewald \& } \\
\text { J.B. Reeside, Jr., June 24, } 1921\end{array}$ & 74,132 & 9,57 \\
\hline 7496 & $1 / 2$ mi W of Pagosa Junction, $\mathrm{CO}$ & $37.038044^{\circ},-107.207448^{\circ}$ & $\begin{array}{l}\text { Q.D. Singewald, Knickenbacker } \\
\text { \& J.B. Reeside, Jr., June 4, } 1921\end{array}$ & $\begin{array}{l}8,53,70,73,84,86,97,99,109,127, \\
129,155,157\end{array}$ & $9,24,48,57$ \\
\hline 7498 & $\begin{array}{l}\text { On Cat Cr., } \sim 1 \mathrm{mi} \mathrm{N} \text { of Pagosa } \\
\text { Junction, } \mathrm{CO}\end{array}$ & $37.049781^{\circ},-107.198219^{\circ}$ & $\begin{array}{l}\text { Q.D. Singewald, J.B. Reeside, Jr., } \\
\text { June 5, } 1921\end{array}$ & 132 & $9,48,57$ \\
\hline 7538 & $\begin{array}{l}2.3 \text { mi N NW of Sand Springs } \\
\text { School, MT }\end{array}$ & $\begin{array}{l}47.129386^{\circ},-107.510631^{\circ} \\
{[\mathrm{SE} 1 / 4 \text { Sec. } 22, \text { T. } 16 \mathrm{~N}, \mathrm{R} .33 \mathrm{E}]} \\
\end{array}$ & $\begin{array}{l}\text { W.T. Thom, Jr., \& C.E. Dobbin, } \\
\text { May } 27,1921\end{array}$ & $6,10,15,18,79,94,187$ & 9,57 \\
\hline 7547 & $14 \mathrm{mi}$ NE of Big Timber, MT & $45.992861^{\circ},-109.720544^{\circ}$ & H.H. Graff, 1922 & 96 & 9,57 \\
\hline 7548 & $\sim 11 \mathrm{mi}$ NE of Big Timber, MT & $45.957631^{\circ},-109.742431^{\circ}$ & H.H. Graff, 1922 & $34,35,78$ & 9,57 \\
\hline $\begin{array}{l}7552, \\
8540\end{array}$ & $\begin{array}{l}\text { Clay pit, } 1 \text { mi S of Dickinson, } \\
\text { ND }\end{array}$ & $46.860969^{\circ},-102.813448^{\circ}$ & D. White, Sept. 1907 & 80,96 & $9,37,57$ \\
\hline 7623 & $\begin{array}{l}\text { At Pugh's place, NE of Craig, } \\
\text { CO }\end{array}$ & $40.689194^{\circ},-107.347112^{\circ *}$ & Missing Data & Missing Data & 9 \\
\hline 7659 & $10 \mathrm{mi} \mathrm{W}$ of Colstrip, MT & $45.850558^{\circ},-106.805240^{\circ}$ & C.E. Dobbin, 1923 & 131,158 & $9,17,57$ \\
\hline 7662 & $14 \mathrm{mi}$ NNW of Lame Deer, MT & $\begin{array}{l}45.790883^{\circ},-106.822185^{\circ} \\
{[\mathrm{SE} 1 / 4 \text { Sec. } 36, \text { T. } 1 \text { N, R. } 39 \mathrm{E}]}\end{array}$ & C.E. Dobbin, 1923 & 69,144 & $9,17,57$ \\
\hline 7663 & $4 \mathrm{mi} \mathrm{W}$ of Camp Crook, SD & $45.552417^{\circ},-104.042506^{\circ}$ & C.E. Dobbin, 1923 & 8 & 9,57 \\
\hline 7685 & $\begin{array}{l}\text { Hanging Woman Divide, SE } \\
\text { of Birney, MT }\end{array}$ & $\begin{array}{l}45.272128^{\circ},-106.427672^{\circ} \\
{[N E 1 / 4 \text { Sec. } 35, \text { T. } 6 \text { S, R. } 43 \text { E] }}\end{array}$ & Bass, Aug. 24, 1923 & 104 & 9,57 \\
\hline 7688 & $\begin{array}{l}\text { Valley of Hungry Woman Cr., } \\
\text { MT }\end{array}$ & $45.300453^{\circ},-106.480795^{\circ *}$ & J.B. Stone, Sept. 131923 & 66 & 9 \\
\hline 7695 & $\begin{array}{l}\text { Valley of Hanging } \\
\text { Woman Cr., MT }\end{array}$ & $45.300121^{\circ},-106.483405^{\circ *}$ & J.B. Stone, Sept. 13, 1923 & 78 & 9,57 \\
\hline $\begin{array}{l}7776, \\
8652\end{array}$ & $\begin{array}{l}2 \text { mi SE of coal mine at Black } \\
\text { Buttes, WY }\end{array}$ & $41.537376^{\circ},-108.666702^{\circ}$ & $\begin{array}{l}\text { T.W. Stanton \& J.B. Reeside, Jr., } \\
\text { Aug. } 3,1924\end{array}$ & $16,81,139$ & $9,57,66$ \\
\hline $\begin{array}{l}7839 \\
8249\end{array}$ & $\begin{array}{l}\text { On little knoll, } 2 \text { mi SW of } \\
\text { Edwards, MT }\end{array}$ & $47.117158^{\circ},-107.350972^{\circ}$ & $\begin{array}{l}\text { R.W. Brown \& J. Murata, } \\
\text { Sept., } 17,1931\end{array}$ & $26,32,36,104$ & 9,57 \\
\hline 7989 & Station N 50, Weldon, MT & $47.616008^{\circ},-105.891536^{\circ *}$ & A.J. Collier, June 22, 1929 & 36 & $9,14,25,57$ \\
\hline 8163 & Sweeny Cr., MT & $\begin{array}{l}46.198964^{\circ},-106.294394^{\circ} \\
{[\mathrm{SW} 1 / 4 \text { Sec. } 12, \text { T. } 5 \text { N, R. } 43 \text { E] }}\end{array}$ & R.W. Brown, 1929 & 69,131 & 9,57 \\
\hline 8164 & $\sim 8.4 \mathrm{mi} \mathrm{W}$ SW of Garland, MT & $\begin{array}{l}45.998056^{\circ},-106.098818^{\circ} \\
{[\text { Sec. 23, T. } 3 \text { N, R. } 45 \mathrm{E}]}\end{array}$ & R.W. Brown, Sept. 16, 1929 & $6,22,80$ & 9,57 \\
\hline
\end{tabular}




\begin{tabular}{|c|c|c|c|c|c|}
\hline $\begin{array}{l}\text { Locality } \\
\text { number }\end{array}$ & Brief Description & $\begin{array}{c}\text { Latitude, Longitude } \\
\text { [and original coordinates] }\end{array}$ & Collectors, Date & Taxon list & Reference \\
\hline 8165 & $\begin{array}{l}\text { Below top of hill at Last Flag, } \\
\sim 10 \text { mi NE of Garland, MT }\end{array}$ & $46.184052^{\circ},-105.833706^{\circ}$ & R.W. Brown, Sept. 25, 1929 & 36,151 & 9,57 \\
\hline 8166 & SE of Colstrip, MT & $45.860036^{\circ},-106.594856^{\circ *}$ & R.W. Brown, July 9, 1929 & $67,153,156$ & 9,57 \\
\hline 8167 & $27 \mathrm{mi} \mathrm{N}$ of Ashland, MT & $\begin{array}{l}45.964781^{\circ},-106.231061^{\circ} \\
{[S W \text { corner Sec. } 35, \text { T. } 3 \mathrm{~N},} \\
\text { R. } 44 \mathrm{E}]\end{array}$ & R.W. Brown, July 1, 1929 & $96,164,185$ & 9,57 \\
\hline 8187 & $3.5 \mathrm{mi} \mathrm{S}$ of Ramah, CO & $\begin{array}{l}39.068364^{\circ},-104.158881^{\circ} \\
{[\mathrm{NW} 1 / 4 \text { Sec. } 30, \text { T. } 11 \text { S, R. } 60 \mathrm{~W}]}\end{array}$ & $\begin{array}{l}\text { C.H. Dane \& party (Pierce), } \\
\text { Aug. } 24,1931\end{array}$ & 132 & 9,57 \\
\hline 8188 & S of Ramah, CO & $\begin{array}{l}39.068939^{\circ},-104.165939^{\circ} \\
{[\mathrm{NE} 1 / 4 \text { Sec. } 25, \text { T. } 11 \text { S, R. } 61 \mathrm{~W}]}\end{array}$ & $\begin{array}{l}\text { C.H. Dane \& party (Pierce), } \\
\text { Aug. 26, } 1931\end{array}$ & $18,43,46,74,96,122,131,141$ & 9,57 \\
\hline 8190 & $\begin{array}{l}\text { Left bank of Yellowstone R., } \\
1 \mathrm{mi} \text { N of Intake, MT }\end{array}$ & $47.306122^{\circ},-104.525469^{\circ}$ & $\begin{array}{l}\text { R.W. Brown \& K.J. Murata, } \\
\text { Aug. } 21,1931\end{array}$ & $104,139,154$ & 9,57 \\
\hline 8191 & $\begin{array}{l}\text { Cliffs along left bank of } \\
\text { Yellowstone R., } 0.5 \text { to } 2 \mathrm{mi} \\
\mathrm{N} \text { of Burns Ranch, MT }\end{array}$ & $47.384561^{\circ},-104.405642^{\circ}$ & $\begin{array}{l}\text { R.W. Brown \& K.J. Murata, } \\
\text { Aug. 20, } 1931\end{array}$ & 40 & 9,57 \\
\hline 8192 & $\begin{array}{l}\text { Right bank of Yellowstone R, } \\
\text { E of Sidney, MT }\end{array}$ & $47.708036^{\circ},-104.085789^{\circ}$ & J. Murata, Aug. 18, 1931 & 153 & 9,57 \\
\hline 8193 & $\begin{array}{l}\text { Right bank of Yellowstone R., } \\
\text { E of Sidney, MT }\end{array}$ & $47.711175^{\circ},-104.084872^{\circ}$ & $\begin{array}{l}\text { R.W. Brown \& J. Murata, } \\
\text { Aug. 18, } 1931\end{array}$ & 32 & 9,57 \\
\hline 8195 & $\begin{array}{l}\text { Right bank of Yellowstone R., } \\
\text { E of Sidney, MT }\end{array}$ & $47.710833^{\circ},-104.084853^{\circ}$ & $\begin{array}{l}\text { R.W. Brown \& J. Murata, } \\
\text { Aug. 18, } 1931\end{array}$ & $40 \mathrm{a}, 51,146$ & 9,57 \\
\hline 8199 & $\begin{array}{l}4 \text { mi up Seven Mile Cr. from } \\
\text { Stipek, MT }\end{array}$ & $47.258232^{\circ},-104.717874^{\circ}$ & $\begin{array}{l}\text { R.W. Brown \& J. Murata, } \\
\text { Aug. 22, } 1931\end{array}$ & 79,196 & 9,57 \\
\hline 8200 & $\begin{array}{l}3 \text { mi up Clear Cr., Left bank, } \\
\text { W of Glendive, MT }\end{array}$ & $46.981206^{\circ},-104.863672^{\circ}$ & L.F. Ward, Aug. 1883 & $22,67,78,155,156$ & 9,72 \\
\hline 8202 & $\begin{array}{l}\text { On rd toward Hofflund along } \\
\text { left bank of Missouri R., } 10 \mathrm{mi} \\
\mathrm{N} \text { of Sanish, ND }\end{array}$ & $48.079957^{\circ},-102.657186^{\circ}$ & $\begin{array}{l}\text { R.W. Brown, T.W. Stanton \& } \\
\text { J. Murata, July 24, } 1931\end{array}$ & 2 & 9,57 \\
\hline 8203 & $\begin{array}{l}\text { 5-6 mi on rd NW of Sanish, } \\
\text { toward Hofflund on E side of } \\
\text { Missouri R., ND }\end{array}$ & $48.043565^{\circ},-102.601066^{\circ}$ & R.W. Brown, July 24, 1931 & 32 & 9,57 \\
\hline 8204 & $30 \mathrm{ft}$ above 8203 & $48.043565^{\circ},-102.601066^{\circ}$ & R.W. Brown, July 24, 1931 & 6,22 & 9,57 \\
\hline 8205 & $\begin{array}{l}18.4 \mathrm{mi} \text { along river rd from } \\
\text { Sanish to Hofflund, ND }\end{array}$ & $48.130729^{\circ},-102.759216^{\circ}$ & R.W. Brown, July 24, 1931 & 80 & 9,57 \\
\hline 8206 & $\begin{array}{l}6 \text { mi N of Armstrong } \\
\text { (underwater), E of trail leading } \\
\text { down to river, on rd Sanish to } \\
\text { Hoflund, ND }\end{array}$ & $47.582402^{\circ},-102.007616^{\circ}$ & $\begin{array}{l}\text { T.W. Stanton, R.W. Brown \& } \\
\text { J. Murata, July 22, } 1931\end{array}$ & $30,32,38,51,67,69,104,122$ & $9,57,60$ \\
\hline 8212 & $\begin{array}{l}4 \mathrm{mi} \mathrm{N} \text { of mouth of Rising } \\
\text { Water Cr., N of Elbowoods, ND }\end{array}$ & $47.724465^{\circ},-102.172428^{\circ}$ & $\begin{array}{l}\text { R. W. Brown, T.W. Stanton \& } \\
\text { J. Murata, July 23, } 1931\end{array}$ & $14,32,36,40 \mathrm{a}$ & $9,57,60$ \\
\hline 8213 & $5 \mathrm{mi}$ SE of Elbowoods, ND & $47.524998^{\circ},-102.089970^{\circ}$ & R.W. Brown, July 22, 1931 & 153 & $9,38,57,60$ \\
\hline 8215 & $\begin{array}{l}9 \text { mi N of Sixmile Cr., } \\
\text { Armstrong, ND }\end{array}$ & $47.605435^{\circ},-102.062961^{\circ}$ & Missing Data & Missing Data & 9,60 \\
\hline 8220 & $\begin{array}{l}\text { Hoffman Mine, W of Sanish, } \\
\text { W bluff of Missouri R., ND }\end{array}$ & $47.975256^{\circ},-102.593410^{\circ *}$ & R.W. Brown, June 25, 1931 & 21 & $3,9,57$ \\
\hline 8222 & $\begin{array}{l}\text { At first of Blue Buttes, S of } \\
\text { Keene, ND }\end{array}$ & $47.880278^{\circ},-102.850556^{\circ}$ & $\begin{array}{l}\text { R.W. Brown \& J. Murata, } \\
\text { June 25, } 1931\end{array}$ & $9,36,51,153$ & $9,56,57$ \\
\hline 8224 & $\begin{array}{l}\text { At Brittian Mine, } 6 \text { mi SE of } \\
\text { Mott, ND }\end{array}$ & $46.314546^{\circ}-102.259102^{\circ}$ & $\begin{array}{l}\text { R.W. Brown \& J. Murata, } \\
\text { July } 6,1931\end{array}$ & $32,40,51,58,104,147,156$ & $7,9,56,57$ \\
\hline 8225 & $\begin{array}{l}\text { At Hoffman mine, Right bank of } \\
\text { Missouri R., W bluff, across from } \\
\text { Sanish, ND }\end{array}$ & $47.975256^{\circ},-102.593410^{\circ} *$ & $\begin{array}{l}\text { R.W. Brown \& J. Murata, } \\
25 \text { June } 1931\end{array}$ & 131,155 & $3,9,57$ \\
\hline 8227 & $\begin{array}{l}\text { Erz Mine stripping, } 3 \mathrm{mi} \mathrm{N} \text { of } \\
\text { Watauga, SD }\end{array}$ & $45.965996^{\circ},-101.540862^{\circ}$ & $\begin{array}{l}\text { R.W. Brown \& J. Murata, } \\
\text { July } 10,1931 \\
\end{array}$ & $30,38,75,89,96,104,131$ & $9,56,57$ \\
\hline 8229 & $\begin{array}{l}\text { Phelan's Ranch on Little } \\
\text { Missouri R., ND }\end{array}$ & $46.512745^{\circ},-103.840967^{\circ}$ & $\begin{array}{l}\text { R.W. Brown \& J. Murata, } \\
\text { Aug. 10, } 1931\end{array}$ & 142 & 9 \\
\hline $\begin{array}{l}8230 \\
8234\end{array}$ & $\begin{array}{l}\mathrm{N} \text { of rd; } ~ 5 \text { mi W of Grassy } \\
\text { Butte, ND }\end{array}$ & $47.414883^{\circ},-103.328622^{\circ *}$ & $\begin{array}{l}\text { R.W. Brown, T.W. Stanton \& } \\
\text { J. Murata, June } 28,1931\end{array}$ & $29,51,96,151,156,164$ & 9,57 \\
\hline $\begin{array}{l}8231 \\
8232 \\
8233 \\
\end{array}$ & $\begin{array}{l}\text { W of Grassy Butte, near } \\
\text { Bicycle P.O., ND }\end{array}$ & $47.417545^{\circ},-103.373365^{\circ *}$ & R.W. Brown, July 28, 1931 & 10,58 & $7,9,57$ \\
\hline 8236 & $\begin{array}{l}\text { On route } 85 \text { just } \mathrm{S} \text { of Little } \\
\text { Missouri R. crossing, } \sim 17 \mathrm{mi} \mathrm{S} \\
\text { of Watford City, ND }\end{array}$ & $47.583991^{\circ},-103.248770^{\circ}$ & J. Murata, July 27, 1931 & 164 & 9 \\
\hline 8238 & $\begin{array}{l}\text { Near top of Sentinel Butte, ND } \\
\text { J. Murata, July 29, } 1931\end{array}$ & $46.877394^{\circ},-103.848789^{\circ}$ & $\begin{array}{l}\text { R.W. Brown, T.W. Stanton \& } \\
\text { Leonard, Aug. 10, } 1908\end{array}$ & 36 & 9,57 \\
\hline 8239 & $\begin{array}{l}\text { Steven's Ranch, left bank of } \\
\text { Little Missouri R., } 3 / 4 \mathrm{mi} \\
\text { S of Yule, ND }\end{array}$ & $46.548083^{\circ},-103.801547^{\circ}$ & $\begin{array}{l}\text { Stanton, R.W. Brown \& } \\
\text { J. Murata, July 29, } 1931\end{array}$ & $36,62-64,104$ & $9,28,57$ \\
\hline 8240 & $\begin{array}{l}\text { Bluffs on Little Missouri R., } \\
3 \text { mi S of Yule, ND }\end{array}$ & $46.527512^{\circ},-103.845407^{\circ}$ & $\begin{array}{l}\text { T.W. Stanton, R.W. Brown \& } \\
\text { J. Murata, July } 30,1931\end{array}$ & $33,104,131,164$ & $9,28,57$ \\
\hline 8245 & $\begin{array}{l}0.5 \mathrm{mi} \mathrm{N} \text { of Ekalaka, MT } \\
\text { on left side of rd toward } \\
\text { Baker, MT }\end{array}$ & $45.897130^{\circ},-104.544803^{\circ}$ & $\begin{array}{l}\text { R.W. Brown \& J. Murata, } \\
\text { Aug. 13, } 1931\end{array}$ & 35 & 9,57 \\
\hline 8246 & $\begin{array}{l}50 \mathrm{ft} \text { above river, right bank of } \\
\text { Yellowstone R. opposite } \\
\text { Terry, MT }\end{array}$ & $46.803838^{\circ},-105.294710^{\circ *}$ & $\begin{array}{l}\text { R.W. Brown \& J. Murata, } \\
\text { Aug. 24, } 1931\end{array}$ & 72,74 & $9,31,57$ \\
\hline 8247 & $\begin{array}{l}\text { Halfway up cliff, left bank of } \\
\text { Yellowstone R., opposite of } \\
\text { Terry, MT }\end{array}$ & $46.810110^{\circ},-105.298413^{\circ *}$ & $\begin{array}{l}\text { R.W. Brown \& J. Murata, } \\
\text { Aug. 24, } 1931\end{array}$ & 173 & $9,31,57$ \\
\hline
\end{tabular}




\begin{tabular}{|c|c|c|c|c|c|}
\hline $\begin{array}{l}\text { Locality } \\
\text { number }\end{array}$ & Brief Description & \begin{tabular}{|c|} 
Latitude, Longitude \\
[and original coordinates]
\end{tabular} & Collectors, Date & Taxon list & Reference \\
\hline 8248 & $\begin{array}{l}\text { Frank Roberts coal Mine, } 3 \mathrm{mi} \text {. } \\
\text { W of Amidon, ND }\end{array}$ & $46.485647^{\circ},-103.390955^{\circ}$ & $\begin{array}{l}\text { R.W. Brown \& J. Murata, } \\
\text { Aug. } 121931\end{array}$ & 21 & 9 \\
\hline 8250 & $\begin{array}{l}\text { N face of Signal Butte, S of } \\
\text { Miles City, MT }\end{array}$ & $46.388953^{\circ},-105.756754^{\circ}$ & $\begin{array}{l}\text { R.W. Brown \& J. Murata, } \\
\text { Sept. 5, } 1931\end{array}$ & 147 & 9 \\
\hline 8252 & $\begin{array}{l}\text { W of Forsyth, MT, } 8 \text { mi S of } \\
\text { mouth of Armell Cr., E of Cr }\end{array}$ & $46.167147^{\circ},-106.803265^{\circ}$ & $\begin{array}{l}\text { R.W. Brown \& J. Murata, } \\
\text { Sept. 15, } 1931\end{array}$ & 3 & 9,57 \\
\hline 8253 & $\begin{array}{l}2 \text { mi E of Powder R. bridge, } \\
\text { Mizpah, on rd to Ekalaka } \\
\text { and Ismay, MT }\end{array}$ & $46.239439^{\circ},-105.226092^{\circ}$ & J. Murata, Sept. 4, 1931 & 63,104 & $9,15,57$ \\
\hline 8255 & Colstrip, MT & $45.879211^{\circ},-106.612783^{\circ}$ & $\begin{array}{l}\text { R.W. Brown \& J. Murata, } \\
\text { Sept. 10, } 1931 \\
\end{array}$ & $58,67,69,96,131,155,156$ & 9,57 \\
\hline 8256 & $\begin{array}{l}8 \text { mi S of mouth of Armell Cr., } \\
\text { E of Cr, W of Forsyth, MT }\end{array}$ & $46.167352^{\circ},-106.802973^{\circ}$ & $\begin{array}{l}\text { R.W. Brown \& J. Murata, } \\
\text { Sept. 15, } 1931\end{array}$ & $29,32,35,44$ & 9,57 \\
\hline 8257 & $\begin{array}{l}\text { Up Harris Cr., } \sim 5 \mathrm{mi} \mathrm{NE} \text { of } \\
\text { Kinsey, MT }\end{array}$ & $46.619993^{\circ},-105.632020^{\circ}$ & $\begin{array}{l}\text { R.W. Brown \& J. Murata, } \\
\text { Sept. 12, } 1931\end{array}$ & $63,79,147$ & 9,57 \\
\hline 8258 & $\begin{array}{l}1 \text { mi E of Hathaway, MT. } \\
\text { Right side of rd toward Miles } \\
\text { City, at base of bluffs }\end{array}$ & $46.278262^{\circ},-106.170334^{\circ}$ & R.W. Brown, Sept. 11, 1931 & $2,13,32,36,39,104$ & 9,57 \\
\hline 8259 & $\begin{array}{l}1 \mathrm{mi} \text { E of Hathaway, MT. } \\
\text { Right side of rd toward Miles } \\
\text { City, } 50 \mathrm{ft} \text { from top of bluffs }\end{array}$ & $46.277204^{\circ},-106.169493^{\circ}$ & R.W. Brown, Sept. 11, 1931 & Missing Data & 9,57 \\
\hline 8261 & $\begin{array}{l}2 \mathrm{mi} \text { W of Cap Rock, on rd } \\
\text { Kinsey to Cap Rock, } 18 \mathrm{mi} \\
\text { NE of Miles City, MT } \\
\end{array}$ & $46.582305^{\circ},-105.743230^{\circ}$ & $\begin{array}{l}\text { R.W. Brown \& J. Murata, } \\
\text { Sept. 12, } 1931\end{array}$ & 72 & \begin{tabular}{|l|}
9,57 \\
\end{tabular} \\
\hline 8262 & $\begin{array}{l}\text { At Cap Rock, N side of } \\
\text { Yellowstone R., } 20 \mathrm{mi} \text { E of } \\
\text { Miles City, MT }\end{array}$ & $46.594333^{\circ},-105.714221^{\circ}$ & $\begin{array}{l}\text { R.W. Brown \& J. Murata, } \\
\text { Sept. 12, } 1931\end{array}$ & 89 & 9,57 \\
\hline $8307^{1}$ & SE of Calhan, CO & $\begin{array}{l}39.017943^{\circ},-104.269035^{\circ} \\
{\left[N W^{1} / 4 \text { Sec. } 7, \text { T. } 12 \text { S, R. } 61 \mathrm{~W}\right]}\end{array}$ & C. Dane \& White, Sept. 15, 1931 & $51,84,132$ & 9,57 \\
\hline 8426 & $\begin{array}{l}6 \text { mi S and a little E of Como, } \\
\text { South Park, CO } \\
\end{array}$ & $39.234679^{\circ}-105.865260^{\circ}$ & J. Harlan Johnson & 81 & $9,57,73$ \\
\hline 8447 & $6 \mathrm{mi} \mathrm{S}$ of Como, $\mathrm{CO}$ & $39.240071^{\circ},-105.886943^{\circ}$ & J. Harlan Johnson & $8,17,131,136$ & 9,57 \\
\hline $\begin{array}{l}\text { UGS } \\
8493\end{array}$ & $\begin{array}{l}12 \mathrm{ft} \text { above } 8447,6 \mathrm{mi} \mathrm{S} \text { of } \\
\text { Como, CO }\end{array}$ & $39.240071^{\circ},-105.886943^{\circ}$ & J. Harlan Johnson 1934 & 32 & 9,57 \\
\hline 8516 & $\begin{array}{l}1 \mathrm{mi} \text { E of filling station near } \\
\text { Dana, on Lincoln Hw y } 30, \mathrm{WY}\end{array}$ & $41.793485^{\circ},-106.754687^{\circ}$ & $\begin{array}{l}\text { R.W. Brown \& F.S. MacNeill, } \\
10 \text { Sept. } 1936\end{array}$ & $72,74,75,82,85,132,148$ & $9,57,70$ \\
\hline 8517 & $\begin{array}{l}\mathrm{N} \text { of U.S. Hwy 10, right bank of } \\
\text { Moon Cr., } 10.5 \mathrm{mi} \mathrm{W} \text { of } \\
\text { Miles City, MT }\end{array}$ & $46.321091^{\circ},-106.004627^{\circ}$ & $\begin{array}{l}\text { R.W. Brown, F. S. MacNeill, } \\
\text { Aug. 21, } 1936\end{array}$ & $2,23,95,96,122,131,136$ & 9,57 \\
\hline 8519 & $\begin{array}{l}\text { S and } 50 \mathrm{ft} \text { above level of U.S. } \\
\text { Hwy, } 4.5 \mathrm{mi} \text { E of Shirley and } \\
25 \text { miles E of Miles City, MT }\end{array}$ & $46.642219^{\circ},-105.520181^{\circ}$ & $\begin{array}{l}\text { R.W. Brown, F.S. MacNeill, } \\
\text { Aug.14, } 1936\end{array}$ & $\begin{array}{l}5,12,16,20,21,21,31,40,41 \\
47,58,95,96,122,128,135,144, \\
153-155,175,179,182\end{array}$ & 9,57 \\
\hline 8520 & $\begin{array}{l}\text { Foley Brothers Pit no.1, } \\
\text { Colstrip, MT }\end{array}$ & $45.879211^{\circ},-106.612783^{\circ}$ & $\begin{array}{l}\text { R.W. Brown, F.S. MacNeil, } \\
\text { Aug. 20, } 1936\end{array}$ & 153 & 9,57 \\
\hline 8521 & $\begin{array}{l}\text { N of George Newlin Ranch, } \\
\text { Ashland, MT }\end{array}$ & $45.643339^{\circ},-106.264819^{\circ}$ & R.W. Brown, Aug. 141939 & $32,36,59,69,131,154$ & 9,57 \\
\hline 8522 & $\begin{array}{l}\text { S side of Dry Cr., S of jct } \\
\text { of roads } 310 \text { and } 20,5 \mathrm{mi} \mathrm{W} \\
\text { of Greybull, WY }\end{array}$ & $44.499513^{\circ},-108.128939^{\circ}$ & $\begin{array}{l}\text { R.W. Brown \& F. S. MacNeill, } \\
\text { Sept. 2, } 1936\end{array}$ & $29,32,34,57,163,182$ & 9,57 \\
\hline 8523 & Sweetgrass Cr., MT & $\begin{array}{l}46.170931^{\circ},-110.152794^{\circ} \\
{[\text { Sec. } 19, \text { T. } 5 \text { N, R. } 13 \mathrm{E}]}\end{array}$ & $\begin{array}{l}\text { R.W. Brown, F.S. MacNeill, } \\
\text { A.C. Silberling \& W. Hende- } \\
\text { koper, Aug. } 281936\end{array}$ & $51,67,98,122,131,156$ & 9,57 \\
\hline 8526 & $\begin{array}{l}\text { near Jepsen mammal quarry on } \\
\text { Polecat Bench, W of Frannie, } \\
\text { WY }\end{array}$ & \begin{tabular}{|l|}
$44.893075,-108.752486$ \\
\end{tabular} & $\begin{array}{l}\text { R.W. Brown \& F.S. MacNeill, } \\
\text { Sept. } 1,1936\end{array}$ & 45 & $9,26,57$ \\
\hline 8528 & $\begin{array}{l}3 / 4 \text { mi E of Dana filling station } \\
\text { on Hwy } 30, W Y\end{array}$ & $41.791070^{\circ},-106.757906^{\circ}$ & $\begin{array}{l}\text { R.W. Brown \& F.S. MacNeill, } \\
\text { Sept. 2, } 1936\end{array}$ & 132 & $9,57,70$ \\
\hline 8529 & $\begin{array}{l}\text { N side of old rd to Musselshell, } \\
10 \mathrm{mi} \text { E of Roundup, MT }\end{array}$ & \begin{tabular}{|l|}
$46.48075,-108.342306$ \\
\end{tabular} & R.W. Brown, Aug. 26, 1936 & 32 & 9,57 \\
\hline 8530 & $\begin{array}{l}\text { Tusler, MT, S of rd at curve and } \\
\text { cutbank on Hwy } 10,15 \mathrm{mi} \\
\text { E of Miles City }\end{array}$ & $46.558653^{\circ},-105.615498^{\circ}$ & $\begin{array}{l}\text { R.W. Brown \& F.S. MacNeill, } \\
\text { Aug. 22, } 1936=\text { UF loc. } 19013\end{array}$ & $95,96,104,177$ & 9,57 \\
\hline 8535 & $\begin{array}{l}\text { Poison Spider Cr., SW of } \\
\text { Casper, WY }\end{array}$ & $42.783875^{\circ},-106.531261^{\circ}$ & $\begin{array}{l}\text { C.E. Dobbin, R.W. Brown \& } \\
\text { F.S. MacNeill, July 13, Sept. 7, } \\
1936 \\
\end{array}$ & 23 & 9,57 \\
\hline 8542 & $\begin{array}{l}1 \text { mi E of Intake, MT on } \\
\text { conical hill near stone quarry } \\
\mathrm{N} \text { of Hwy }\end{array}$ & $47.302999^{\circ},-104.513182^{\circ}$ & $\begin{array}{l}\text { R.W. Brown, F.S. MacNeill, } \\
\text { Aug. 4, } 1936\end{array}$ & 147 & 9,57 \\
\hline 8545 & $\begin{array}{l}\text { E of Hwy from Forsyth to } \\
\text { Colstrip, near station on rr } \\
\text { branch to Colstrip, MT }\end{array}$ & $46.083967^{\circ},-106.721658^{\circ}$ & $\begin{array}{l}\text { R.W. Brown, F.S. MacNeill, } \\
\text { Aug. 20,1936 }\end{array}$ & $45,96,131$ & 9,57 \\
\hline 8547 & $\begin{array}{l}\text { S side of Lebo Cr., at type } \\
\text { section of the Lebo Fm., MT }\end{array}$ & $46.257664^{\circ},-110.085281^{\circ *}$ & F.S. MacNeill, Aug. 29, 1936 & $104,134,177$ & $9,57,68$ \\
\hline 8548 & $\begin{array}{l}\text { On rd } \mathrm{N} \text { from US Hwy } 30 \\
\text { from point about } 2 \mathrm{mi} \mathrm{W} \text { of } \\
\text { Hanna, WY }\end{array}$ & $41.890819^{\circ},-106.625464^{\circ}$ & $\begin{array}{l}\text { R.W. Brown \& F.S. MacNeill, } \\
\text { Sept. } 10,1936\end{array}$ & 23 & 9 \\
\hline 8549 & $\begin{array}{l}1 \text { mi E of Hathaway, halfway } \\
\text { up slope of bluff S of Hwy, MT }\end{array}$ & $46.277161^{\circ},-106.169569^{\circ}$ & $\begin{array}{l}\text { R.W. Brown \& F.S. MacNeill, } \\
\text { Aug. 21, } 1936\end{array}$ & 32,34 & 9,57 \\
\hline $\begin{array}{l}8550 \\
8553\end{array}$ & $\begin{array}{l}\text { On rd to Cap Rock, 18-18.5 } \\
\text { mi NE of Miles City, MT }\end{array}$ & $46.582305^{\circ},-105.743230^{\circ}$ & $\begin{array}{l}\text { R.W. Brown \& F.S. MacNeill, } \\
\text { Aug. } 17,1936\end{array}$ & $36,95,104,142$ & 9,57 \\
\hline
\end{tabular}




\begin{tabular}{|c|c|c|c|c|c|}
\hline $\begin{array}{l}\text { Locality } \\
\text { number }\end{array}$ & Brief Description & $\begin{array}{c}\text { Latitude, Longitude } \\
\text { [and original coordinates] }\end{array}$ & Collectors, Date & Taxon list & Reference \\
\hline 8551 & $\begin{array}{l}\text { MC Mine, } 0.5 \text { mi E of Sand Cr. } \\
\text { Bridge, } \sim 7 \mathrm{mi} \mathrm{N} \text { of Glenrock, WY }\end{array}$ & $42.961450^{\circ},-105.837983^{\circ}$ & $\begin{array}{l}\text { R.W. Brown \& F.S. MacNeill, } \\
\text { Sept. } 5,1936\end{array}$ & $\begin{array}{l}8,27,32,51,57,58,72,75,84,87 \\
96,114,132,141,180\end{array}$ & 9,57 \\
\hline 8552 & $\begin{array}{l}3 \text { mi W of Marsh, near Coulin } \\
\text { Station on RR, W of } \\
\text { Glendive, MT }\end{array}$ & $46.866000^{\circ},-104.991000^{\circ}$ & $\begin{array}{l}\text { R.W. Brown, F.S. MacNeill \& } \\
\text { D. Yri, Aug. 3, } 1936\end{array}$ & $32,58,63,72,104,108,112,131$ & 9,57 \\
\hline 8554 & $\begin{array}{l}\text { On N side of Yellowstone R., } \\
\text { opposite Terry, MT }\end{array}$ & $46.809836^{\circ},-105.307483^{\circ *}$ & $\begin{array}{l}\text { R.W. Brown \& F.S. MacNeill, } \\
\text { Aug. } 12,1936\end{array}$ & 155 & $9,31,57$ \\
\hline 8556 & $\begin{array}{l}10 \text { mi N of Terry on rd to Crow } \\
\text { Rock, } \sim 2 \text { mile } \mathrm{W} \text { of bridge in } \\
\text { a cut bank of Cherry Cr., MT }\end{array}$ & $46.873578^{\circ},-105.432589^{\circ}$ & $\begin{array}{l}\text { R.W. Brown \& F.S. MacNeill, } \\
\text { Aug. } 13,1936\end{array}$ & $29,37,40,79,96$ & 9,57 \\
\hline 8558 & $\begin{array}{l}\text { On Lebo Cr., Wallis Hende- } \\
\text { koper Ranch, } 1 \frac{1}{2} \mathrm{mi} \text { S of } \\
\text { Buckley, MT }\end{array}$ & $46.256550^{\circ},-110.100872^{\circ}$ & $\begin{array}{l}\text { R.W. Brown \& F.S. MacNeill, } \\
\text { July } 21,1936\end{array}$ & 153 & 9,57 \\
\hline 8566 & $\begin{array}{l}\text { Wyodak Coal Mine, } 4 \frac{1}{2} 2 \mathrm{mi} \mathrm{E} \text { of } \\
\text { Gillette, WY }\end{array}$ & $44.288336^{\circ},-105.399311^{\circ}$ & $\begin{array}{l}\text { R.W. Brown \& F.S. MacNeill, } \\
\text { Sept. 4, } 1936\end{array}$ & 51,177 & 9,57 \\
\hline 8654 & $\begin{array}{l}300 \mathrm{ft} \mathrm{S} \text { of Hwy } 30,71 \frac{1}{2} \mathrm{mi} \text { E of } \\
\text { Point of Rocks, WY }\end{array}$ & $41.645577^{\circ},-108.665141^{\circ}$ & $\begin{array}{l}\text { R.W. Brown \& C.W. Mumm, } \\
\text { July } 8,1938\end{array}$ & $122,153,164$ & 9,57 \\
\hline 8660 & $\begin{array}{l}1 \mathrm{mi} \text { NE of US Hwy } 30 \text { at } \\
\text { Hadsell, } 10 \mathrm{mi} \mathrm{W} \text { of Rawlins, } \\
\text { WY }\end{array}$ & $41.789362^{\circ},-107.360664^{\circ}$ & $\begin{array}{l}\text { R.W. Brown \& C.W. Mumm, } \\
\text { July } 1,1938\end{array}$ & $51,110,132$ & $9,33,57$ \\
\hline 8662 & $\begin{array}{l}\text { Near bridge crossing, in bluff } \\
\text { on N side of Big Ditch, WY }\end{array}$ & $41.923647^{\circ},-106.786100^{\circ}$ & $\begin{array}{l}\text { R.W. Brown \& C.W. Mumm, } \\
\text { July } 28,1938\end{array}$ & 45 & $9,57,70$ \\
\hline 8668 & $\begin{array}{l}10 \mathrm{mi} \text { S of Rozet, E of } \\
\text { Gillette, WY }\end{array}$ & $44.287803^{\circ},-105.007197^{\circ}$ & R.W. Brown, June 15, 1938 & 110,191 & 9,57 \\
\hline 8669 & $\begin{array}{l}\text { Dump from large rd cut, } 4 \mathrm{mi} \\
\text { W of Bayfield, CO }\end{array}$ & $37.224933^{\circ},-107.670778^{\circ}$ & $\begin{array}{l}\text { R.W. Brown \& C.W. Mumm, } \\
\text { Aug. } 311938\end{array}$ & 191 & 9 \\
\hline 8670 & $\begin{array}{l}\text { Slack pile at mine No. 1, Almy, } \\
2.5 \mathrm{mi} \text { NW of Evanston, WY }\end{array}$ & $41.313864^{\circ},-110.996395^{\circ}$ & $\begin{array}{l}\text { R.W. Brown \& C.W. Mumm, } \\
\text { July } 14,1938\end{array}$ & 32 & $9,57,70$ \\
\hline 8672 & $\begin{array}{l}85 \mathrm{ft} \text { below top of hill, in bank } \\
\text { of Second Cr., } 10 \mathrm{mi} \text { E of } \\
\text { Derby, CO }\end{array}$ & $39.828911^{\circ},-104.721764^{\circ}$ & $\begin{array}{l}\text { R.W. Brown \& Dobbin, } \\
\text { May 25, } 1938\end{array}$ & $45,71,92,96,126,132,147$ & 9 \\
\hline 8673 & $\begin{array}{l}\text { In gully S of rd going W from } \\
\text { Conoco Camp, W of Lance Cr., } \\
\text { WY }\end{array}$ & $43.033397^{\circ},-104.773592^{\circ}$ & $\begin{array}{l}\text { R.W. Brown \& C.W. Mumm, } \\
\text { June 7, } 1938\end{array}$ & $47,93,92,96,131,142,153$ & 9,57 \\
\hline 8677 & $\begin{array}{l}\text { Overlooking Thunder Cr. } \\
\text { in distance to } \mathrm{W}, 8 \mathrm{mi} \\
\mathrm{W} \text { of Clareton, WY }\end{array}$ & $43.671419^{\circ},-104.892869^{\circ}$ & $\begin{array}{l}\text { R.W. Brown \& C.W. Mumm, } \\
\text { June 6, } 1938\end{array}$ & $32,82,104,128,141,142$ & 9,57 \\
\hline 8678 & $250 \mathrm{ft}$ lower than 8677 & $43.670692^{\circ},-104.893050^{\circ}$ & $\begin{array}{l}\text { R.W. Brown \& C.W. Mumm, } \\
\text { June } 6,1938\end{array}$ & $\begin{array}{l}8,12,15,18,19,22,31,41,50,95, \\
122,139,142,153,200\end{array}$ & 9,57 \\
\hline 8775 & $\begin{array}{l}1 \mathrm{mi} \text { E of DeBeque, } \mathrm{CO}, \mathrm{N} \\
\text { side of U.S. Hwy } 6 \text { at curve } \\
\text { on hill }\end{array}$ & $39.334133^{\circ},-108.195764^{\circ}$ & $\begin{array}{l}\text { R.W. Brown, T.D. Lamar, \& } \\
\text { B. Patterson, Sept. 14, } 1939\end{array}$ & 18,182 & 9,57 \\
\hline 8776 & $\begin{array}{l}1 \frac{1}{2} \mathrm{mi} \text { W of Walsenburg, CO, } \\
20 \mathrm{ft} \text { above Cucharas R. }\end{array}$ & $37.612246^{\circ},-104.801667^{\circ}$ & $\begin{array}{l}\text { R.W. Brown \& T.D. Lamar, } \\
\text { July } 31,1939\end{array}$ & 129 & $9,39,40,57$ \\
\hline 8777 & $\begin{array}{l}\text { W side of Platte R., Denver, } \\
\text { CO, near Colfax Pressed Brick } \\
\text { Co. \& } 17^{\text {th }} \text { Ave }\end{array}$ & $39.699628^{\circ},-105.001419^{\circ *}$ & R.W. Brown, June 1, 1939 & $8,70,71,74,81,126$ & $9,11,57$ \\
\hline 8779 & $\begin{array}{l}\text { S side of Jimmy Camp Cr., } \\
3 / 4 \text { mi E of Richfield Springs } \\
\text { Ranch, } 9 \text { mi E of Colorado } \\
\text { Springs, CO }\end{array}$ & $38.854619^{\circ},-104.652958^{\circ}$ & $\begin{array}{l}\text { R.W. Brown \& T.D. Lamar, } \\
\text { Aug. 4, } 1939\end{array}$ & $24,70,71$ & 9,57 \\
\hline 8780 & $\begin{array}{l}\text { S side of Beebe-Powderville Rd, } \\
3.8 \text { mi W of Powderville, MT }\end{array}$ & $45.791842^{\circ},-105.177939^{\circ}$ & R.W. Brown, Aug. 15, 1939 & 95,131 & $9,10,57$ \\
\hline 8781 & $\begin{array}{l}2 \text { mi up Little Powder R. from } \\
\text { jct with Powder R., NE of } \\
\text { Broadus, MT }\end{array}$ & $45.454836^{\circ},-105.328797^{\circ}$ & R.W. Brown, Aug. 10, 1939 & $32,96,146$ & 9,57 \\
\hline 8786 & $\sim 6 \mathrm{mi}$ SW of Broadus, MT & $45.365933^{\circ},-105.540850^{\circ}$ & R.W. Brown, Aug. 9, 1939 & $29,32,36,40 \mathrm{a}, 89$ & 9 \\
\hline 8881 & $1 / 2 \mathrm{mi} \mathrm{W}$ to NW of Ramah, CO & $39.123284^{\circ},-104.173451^{\circ}$ & R.W. Brown, June 13, 1940 & $23,40,104,141$ & 9,57 \\
\hline 8882 & $\begin{array}{l}1 / 2 \mathrm{mi} \text { E of Purdon Mine, } 5 \mathrm{mi} \\
\mathrm{SW} \text { of Ramah, CO }\end{array}$ & $39.064839^{\circ},-104.204025^{\circ}$ & R.W. Brown, June 12, 1940 & 36 & $9,53,57$ \\
\hline 8884 & $\begin{array}{l}2 \text { mi E of Hwy } 87 \text { on county } \\
\text { rd from elevator near Ohlman, } \\
25 \text { mi NW of Sheridan, WY } \\
\end{array}$ & $44.955829^{\circ},-107.290256^{\circ *}$ & $\begin{array}{l}\text { R.W. Brown \& C.E.S. } \\
\text { Sept. } 10,1940\end{array}$ & $8,27,51,96,114,131$ & 9,57 \\
\hline 8885 & $\begin{array}{l}\text { Mackton No. } 2 \text { coal mine, } \\
61 / 2-7 \text { mi NE of Big Sandy, MT } \\
\end{array}$ & $48.182206^{\circ},-109.985564^{\circ}$ & R.W. Brown, Aug. 22, 1940 & $32,36,63,67,69,96,153$ & $6,9,57,58$ \\
\hline 8886 & $\begin{array}{l}\text { W of mouth of Cub Cr., on Otter } \\
\text { Cr., MT, } 50 \mathrm{ft} \text { above wall bed }\end{array}$ & $45.218600^{\circ},-106.185114^{\circ}$ & W. Hass et al., Sept. 6, 1940 & 63 & 9,57 \\
\hline 8887 & Sayle Rd, MT & $\begin{array}{l}45.087182^{\circ},-106.082108^{\circ} \\
{[300 \mathrm{ft} \mathrm{W} \text { of corner between }} \\
\text { sects 33/34, T. } 8 \text { S, R. } 46 \mathrm{E}\end{array}$ & $\begin{array}{l}\text { R.P. Bryson \& R.W. Brown, } \\
\text { Sept. 6, } 1940\end{array}$ & $40 \mathrm{a}, 87,164$ & 9,57 \\
\hline 8888 & $\sim 4.6 \mathrm{mi} \mathrm{NE}$ of Otter, MT & $\begin{array}{l}45.260147^{\circ},-106.141725^{\circ} \\
{[\mathrm{SE} 1 / 4 / \mathrm{NE} 1 / 4 \mathrm{Sec} .6, \text { T. } 7 \mathrm{~S},} \\
\text { R. } 46 \mathrm{E}]\end{array}$ & $\begin{array}{l}\text { R.W. Brown \& R.P. Bryson, } \\
\text { Sept. 6, } 1940\end{array}$ & 79,104 & 9,57 \\
\hline 8893 & $\begin{array}{l}20 \mathrm{mi} \text { N NE of Kaycee, Wy, } \\
3 / 4 \mathrm{mi} \mathrm{S} \text { of bridge over Crazy } \\
\text { Woman Cr., \& } \sim 4 \text { mi E to bluffs }\end{array}$ & $43.975842^{\circ},-106.682025^{\circ *}$ & R.W. Brown, Sept. 17, 1940 & $27,57,96,131$ & 9,57 \\
\hline 8896 & \begin{tabular}{|l} 
Big Timber, MT; Bluff top, \\
N side of Yellowstone R. \\
\end{tabular} & $45.855211^{\circ},-109.959267^{\circ}$ & R.W. Brown, July 19, 1940 & $18,57,79,96$ & 9,57 \\
\hline 8897 & $\begin{array}{l}81 / 2 \text { mi NW of Glendive bridge } \\
\text { over Yellowstone R., MT, } 1 \mathrm{mi} \\
\text { E of Hwy } 18\end{array}$ & $47.125900^{\circ},-104.890200^{\circ}$ & R.W. Brown, Sept. 1, 1940 & $14,15,16,36,58,89,128,144$ & 9,57 \\
\hline
\end{tabular}




\begin{tabular}{|c|c|c|c|c|c|}
\hline $\begin{array}{l}\text { Locality } \\
\text { number }\end{array}$ & Brief Description & \begin{tabular}{|c|} 
Latitude, Longitude \\
[and original coordinates]
\end{tabular} & Collectors, Date & Taxon list & Reference \\
\hline 8899 & $\begin{array}{l}\text { S of Hwy at Gwynn Ranch, } \\
\text { Grass Cr., WY }\end{array}$ & $?$ & R.W. Brown, July 5, 1940 & $10,32,34,71,95,96,131,136,141$ & $9,35,57$ \\
\hline 8901 & $\begin{array}{l}\text { E side of Graveyard Coulee, } \\
\text { S of Glendive, MT }\end{array}$ & $47.101731^{\circ},-104.687421^{\circ}$ & R.W. Brown, Aug. 29, 1940 & 75,126 & 9,57 \\
\hline 8910 & $\begin{array}{l}\text { Bayhorse Cr. (W side), 11/2 mi } \\
\mathrm{N} \text { of Traub Ranch, MT }\end{array}$ & $45.156317^{\circ},-105.691544^{\circ}$ & $\begin{array}{l}\text { R.W. Brown \& M.W. Ellis, } \\
\text { July } 14,1941\end{array}$ & \begin{tabular}{|l|}
$56,52,68,72,96,119,121$, \\
$154,164,175,180,192$
\end{tabular} & 9,57 \\
\hline 8913 & $\begin{array}{l}\text { Sentinel Butte, ND; Small hill } \\
\text { to N of rd leading up to the butte }\end{array}$ & $46.884939^{\circ},-103.849756^{\circ}$ & R.W. Brown, July 28, 1941 & $9,16,40 \mathrm{a}, 63,79,96,178,193,194$ & 9,57 \\
\hline 8917 & $\begin{array}{l}3 \mathrm{mi} \mathrm{E} \text { of Black Buttes, WY; } \\
1 / 4 \mathrm{mi} \mathrm{S} \text { of Hwy, on new rd } \\
\text { from Bitter Cr. to Black Buttes }\end{array}$ & $41.516736^{\circ},-108.654203^{\circ}$ & R.W. Brown, June 18, 1941 & $14,35,57,164,177$ & $9,57,66$ \\
\hline 8920 & $\begin{array}{l}\text { Little Bitter Cr., } 1 / 4 \mathrm{mi} \mathrm{N} \\
\text { of gate on rd, E of rd on hillside, } \\
20 \text { mi S of Rock Springs, WY }\end{array}$ & $41.286367^{\circ},-109.195683^{\circ}$ & R.W. Brown, June 20, 1941 & $40 \mathrm{a}, 56,63,77,80,122,145,154$ & 9,57 \\
\hline 8921 & $\begin{array}{l}\text { Little Bitter Cr., SW } \\
\text { of Antelope Butte, WY }\end{array}$ & $41.372608^{\circ},-109.211536^{\circ}$ & R.W. Brown, June 23, 1941 & \begin{tabular}{|l}
$14,55,58,96,122,136,139,153$ \\
\end{tabular} & $9,57,66$ \\
\hline 8922 & $\begin{array}{l}\text { E side of Bitter Cr., E of Bacon } \\
\text { ranch, S of Rock Springs, WY }\end{array}$ & $41.337985^{\circ},-109.207567^{\circ}$ & $\begin{array}{l}\text { R.W. Brown \& W.H. Bradley, } \\
\text { June 21, } 1941\end{array}$ & $14,30,38,40 a, 72,84,96,131,153$ & 9 \\
\hline 8928 & $\begin{array}{l}\sim 9 \text { mi NW of Craig, CO; bluff } \\
\text { in second gulch NE of Allan } \\
\text { Mckinison Ranch house }\end{array}$ & $40.588308^{\circ},-107.678731^{\circ}$ & R.W. Brown, Sept. 16, 1941 & $8,18,35,59,87,96,129,131$ & 9,57 \\
\hline 8930 & $\begin{array}{l}7 \mathrm{mi} \text { E of Point of Rocks, WY, } \\
1 \mathrm{mi} \mathrm{N} \text { of Hwy } 30\end{array}$ & $41.661797^{\circ},-108.658742^{\circ}$ & R.W. Brown, June 17, 1941 & 55,58 & 9,57 \\
\hline 9056 & $\sim 17 \mathrm{mi}$ SW of Musselshell, MT & $46.300677^{\circ},-108.161213^{\circ *}$ & $\begin{array}{l}\text { R.W. Brown \& H. Hadley, } \\
\text { Sept. 4, } 1944\end{array}$ & 96,153 & 9,57 \\
\hline 9071 & $\begin{array}{l}\sim^{1 / 4} \text { mi E of mouth of Buck Cr., } \\
\text { N side of Fish Cr., WY }\end{array}$ & $43.518719^{\circ},-110.052080^{\circ}$ & \begin{tabular}{|l|} 
Bergquist, \& J.D. Love, \\
July 10,1945 \\
\end{tabular} & 156 & 9,57 \\
\hline 9072 & $1.5 \mathrm{mi}$ SE of Coalwood, MT & $45.707956^{\circ},-105.576319^{\circ}$ & R.P. Bryson, July 3, 1946 & $14,58,88,96$ & 9 \\
\hline 9084 & $17.5 \mathrm{mi} \mathrm{N} \mathrm{NW}$ of Hebron, ND & $\begin{array}{l}47.118339^{\circ},-102.225036^{\circ} \\
{[N W 1 / 4 \text { SW } 1 / 4 \text { Sec. } 16, \text { T. } 142 \mathrm{~N},} \\
\text { R. } 91 \mathrm{~W}] \\
\end{array}$ & $\begin{array}{l}\text { W.E. Benson, R.W. Brown, } \\
\text { July } 9,1947\end{array}$ & 21 & 9 \\
\hline 9085 & $\begin{array}{l}\text { NE side of Young Men's Butte, } \\
\sim 2.5 \text { mi E of Richardton, ND }\end{array}$ & $46.873132^{\circ},-102.240429^{\circ}$ & $\begin{array}{l}\text { W.E. Benson, R.W. Brown, } \\
\text { July } 11,1947\end{array}$ & 21,131 & 9,38 \\
\hline 9104 & $\begin{array}{l}\text { Ranous Coal Mine, Daleview, } \\
\text { MT }\end{array}$ & $48.906783^{\circ},-104.923822^{\circ}$ & $\begin{array}{l}\text { R.W. Brown, R.B. Colton, } \\
\text { Aug. } 29,1949\end{array}$ & $57,58,69,131,136$ & $9,13,57$ \\
\hline 9109 & $\begin{array}{l}12.5 \mathrm{mi} \text { E Riverton, WY, } 3 \mathrm{mi} \mathrm{N} \\
10^{\circ} \mathrm{W} \text { of station on Alkali Butte }\end{array}$ & $\begin{array}{l}42.946569^{\circ},-108.198999^{\circ} \\
{[\mathrm{NW} 1 / 4 \mathrm{SW} 1 / 4 \text { sec. } 29, \text { T. } 1 \mathrm{~S},} \\
\text { R. 6 E] }\end{array}$ & $\begin{array}{l}\text { R.W. Brown, G.N. Piperingos, } \\
\text { K. Yenne, R. Thompson, et al., } \\
\text { July 25-26, } 1949\end{array}$ & $\begin{array}{l}29,37,40,57,65,78,79,96,116 \\
121,139,145,175,187,195\end{array}$ & 9,57 \\
\hline 9111 & $\begin{array}{l}\text { E of Little Dome, Carter Oil } \\
\text { site 2, N of Lander, WY }\end{array}$ & $42.886191^{\circ},-108.734164^{\circ *}$ & missing data & 61,99 & 9 \\
\hline 9129 & Gas Hills, WY & $\begin{array}{l}42.957467^{\circ},-107.680869^{\circ} \\
{[\mathrm{SE} 1 / 4 \mathrm{SE} 1 / 4 \mathrm{Sec} .36, \text { T. } 35 \mathrm{~N},} \\
\text { R. } 91 \mathrm{~W}]\end{array}$ & J.D. Love, K Yenne, Oct., 1950 & $31,40 a, 164$ & 9 \\
\hline 9130 & Gas Hills, WY & $\begin{array}{l}42.872014^{\circ},-107.911092^{\circ} \\
{\left[\mathrm{SW}^{1 / 4} \mathrm{Sec} .31, \text { T. } 34 \text { N, R. } 92 \mathrm{~W}\right]}\end{array}$ & $\begin{array}{l}\text { D. Beardsley, J. Belshe, } \\
\text { K. Yenne, R.W. Brown, } \\
\text { Aug. 1, } 1950\end{array}$ & $27,96,114,131$ & 9 \\
\hline 9132 & SW side of Shotgun Butte, WY & $43.453164^{\circ},-108.727333^{\circ}$ & $\begin{array}{l}\text { R.W. Brown, Troyer, K. Yenne, } \\
\text { W.R. Keefer, Thompson, \& } \\
\text { Burnside, July 26, } 1950\end{array}$ & $61,110,137$ & 9,57 \\
\hline 9134 & Blue Pony coal mine, MT & $\begin{array}{l}48.234982^{\circ},-109.864718^{\circ} \\
{[\mathrm{SW} 1 / 4 \mathrm{SW} 1 / 4 \mathrm{Sec} .25, \text { T. } 29 \mathrm{~N},} \\
\text { R. } 14 \mathrm{E}] \\
\end{array}$ & missing data & 48 & 9 \\
\hline 9180 & $\begin{array}{l}1 \mathrm{mi} \mathrm{W} \text { of RR to Reliance, } \\
\text { along Killpecker Cr., } 3 \mathrm{mi} \mathrm{NW} \\
\text { of Rock Springs, WY } \\
\end{array}$ & $41.619585^{\circ},-109.248113^{\circ}$ & $\begin{array}{l}\text { R.W. Brown \& H.R. Christener, } \\
\text { July } 21,1952\end{array}$ & $36,57,79,122,142$ & 9 \\
\hline 9192 & $\begin{array}{l}\text { N side of Ekalaka-Mizpah Rd, } \\
11 \text { mi E of Powder R., on Grail } \\
\text { (Trail) Cr., MT }\end{array}$ & $46.124858^{\circ},-104.957881^{\circ}{ }^{1}$ & R.W. Brown, Aug. 28, 1946 & 35 & 9,57 \\
\hline 9193 & $\begin{array}{l}\text { Whetstone Falls, on tributary } \\
\text { of Pacific Cr, NE of Moran, WY }\end{array}$ & $43.868742^{\circ},-110.485229^{\circ *}$ & missing data & 33,104 & 9 \\
\hline 9196 & $45 \mathrm{mi} \mathrm{N}$ of Lander, WY & $\begin{array}{l}43.493780^{\circ},-108.778577^{\circ} \\
{[\mathrm{NE} 1 / 4 \mathrm{SE} 1 / 4 \mathrm{sec} .17, \text { T. } 6 \mathrm{~N},} \\
\text { R. 1 E.] }\end{array}$ & missing data & 29,61 & 9 \\
\hline 9198 & $\sim 1$ mi due $\mathrm{S}$ of Riner, $\mathrm{WY}$ & $\begin{array}{l}41.719383^{\circ},-107.550117^{\circ} \\
{\left[\mathrm{SE}^{1 / 4} \mathrm{Sec} .8, \text { T. } 20 \mathrm{~N}, \mathrm{R} .90 \mathrm{~W}\right]} \\
\end{array}$ & R.B. Nace, 15 March 1941 & 52 & 9,57 \\
\hline 9199 & $17 \mathrm{mi} \mathrm{S}$ of Garland, MT & $\begin{array}{l}45.795942^{\circ},-105.888144^{\circ} \\
{[\text { Sec. } 33, \text { T. } 1 \text { N, R. } 47 \mathrm{E}]} \\
\end{array}$ & R.D. Forester, May 3, 1950 & 57 & 9,57 \\
\hline 9200 & $8 \mathrm{mi}$ S of Taylor, ND & $46.776936^{\circ},-102.432233^{\circ}$ & \begin{tabular}{|l|} 
R.L. Coville \\
\end{tabular} & 48 & 9 \\
\hline 9201 & $\begin{array}{l}4 \text { mi E of Mackton Coal Mine, } \\
\text { in Bearpaws, E of Big Sandy, MT }\end{array}$ & $48.166437^{\circ},-109.864908^{\circ}$ & \begin{tabular}{|l|} 
R.W. Brown \& D. Sewart, \\
Sept. 4,1951 \\
\end{tabular} & 174 & 6,9 \\
\hline 9202 & $\begin{array}{l}3 \text { mi E of Fort Stevenson } \\
\text { (submerged), N side of } \\
\text { Missouri R., ND }\end{array}$ & $47.570129^{\circ},-101.414107^{\circ}$ & L.F. Ward, Sept. 17, 1883 & 58 & 9,57 \\
\hline 9203 & $1 \mathrm{mi} \mathrm{S}$ of Como, $\mathrm{CO}$ & $41.891669^{\circ},-106.365225^{\circ}$ & R.W. Brown, June 27, 1938 & 59 & $9,57,70$ \\
\hline 9207 & $\begin{array}{l}\text { W of station on Alkali Butte, } \\
13 \text { mi E of Riverton, WY }\end{array}$ & $42.946164^{\circ},-108.200397^{\circ *}$ & G.N. Pipiringos \& K. Yenne, 1949 & 68 & 9,57 \\
\hline 9208 & $51 \mathrm{mi}$ E of Lander, WY & $\begin{array}{l}42.914273^{\circ} ;-107.728382^{\circ} \\
{[\text { S } 1 / 2 \text { Sec. } 15, \text { T. } 34 \text { N, R. } 91 \mathrm{~W}]}\end{array}$ & missing data & 29,61 & 9 \\
\hline 9209 & $\begin{array}{l}\text { N of Medicine Bow R., S side } \\
\text { of Hwy, directly N of Hanna, } \\
\text { WY }\end{array}$ & $42.017261^{\circ},-106.525482^{\circ *}$ & F.S. MacNeil, Sept. 9, 1936 & 110 & 9 \\
\hline
\end{tabular}




\begin{tabular}{|c|c|c|c|c|c|}
\hline $\begin{array}{l}\text { Locality } \\
\text { number }\end{array}$ & Brief Description & \begin{tabular}{|c|} 
Latitude, Longitude \\
[and original coordinates]
\end{tabular} & Collectors, Date & Taxon list & Reference \\
\hline 9210 & Black Buttes, WY & $\begin{array}{l}41.504053^{\circ},-108.640697^{\circ} \\
{[\mathrm{SE} 1 / 4 \text { Sec. } 26, \text { T. } 18 \mathrm{~N}, \text { R. } 100 \mathrm{~W}]}\end{array}$ & R.L. Nace 1941 & 141 & 9 \\
\hline 9235 & $\begin{array}{l}\text { N side of rd, along LaBarge Cr., } \\
\sim 2 \text { mi E of Viola, WY }\end{array}$ & $42.247417^{\circ},-110.337914^{\circ}$ & R.W. Brown, Sept. 14, 1946 & 110 & 9 \\
\hline 9236 & $\begin{array}{l}\text { Hiawatha Unit well 2, } \\
14 \text { mi E of Diamond Peak, CO }\end{array}$ & $\begin{array}{l}40.990894^{\circ},-108.625644^{\circ} \\
{\left[N W 1 / 4 \mathrm{NW}^{1 / 4,} \text { Sec. } 22, \text { T. } 12 \mathrm{~N},\right.} \\
\text { R. } 100 \mathrm{~W}]\end{array}$ & $\begin{array}{l}\text { Mountain Fuel \& Supply Co., } \\
1952\end{array}$ & 175 & 9 \\
\hline 9237 & $\begin{array}{l}\text { Above white SS of } \\
\text { "Castle Gardens" on Muskrat } \\
\text { Creek, S of Moneta, WY. }\end{array}$ & $43.018119^{\circ},-107.708968^{\circ}$ & missing data & 70 & 9 \\
\hline 9239 & $35 \mathrm{mi}$ SW of Broadus, MT; & $\begin{array}{l}45.067281^{\circ},-105.944092^{\circ} \\
{[\mathrm{NE} 1 / 4 \text { Sec. } 10, \text { T. } 9 \text { S, R. } 47 \text { E] }}\end{array}$ & missing data & 104 & 9 \\
\hline 9248 & $\begin{array}{l}\text { E side of Smoky Butte Cr., } \\
14 \text { mi NW of Jordan, MT }\end{array}$ & $47.399361^{\circ},-107.182475^{\circ *}$ & Barnum Brown, 1906 & 161 & 9,57 \\
\hline 9249 & $\begin{array}{l}\text { SE corner of Sec. } 10, \text { T. } 16 \mathrm{~N}, \\
\text { R. } 38 \mathrm{E}, \mathrm{MT}\end{array}$ & $47.149569^{\circ},-106.890881^{\circ}$ & A.K. Cameron, 1924 & 161 & 9,57 \\
\hline 9252 & $\begin{array}{l}11 \text { mi above mouth of Powder R., } \\
6 \mathrm{mi} \text { SW of Terry, MT }\end{array}$ & $46.735278^{\circ},-105.404033^{\circ}$ & J.B. Clough, 1881 & 132 & 9,31 \\
\hline 9253 & $\begin{array}{l}\text { W side of Little Powder R., } \\
\text { near Biddle, MT }\end{array}$ & $45.090736^{\circ},-105.337442^{\circ *}$ & R.W. Brown, July 15, 1941 & 20,123 & 9 \\
\hline 9322 & $\begin{array}{l}\text { Eagle Coal Mine, } 1 \mathrm{mi} \mathrm{S} \mathrm{og} \\
\text { Bear Cr., MT }\end{array}$ & $45.149825^{\circ},-109.169369^{\circ *}$ & A.M.N.H., May 8, 1905 & $50,78,153,154$ & $9,57,78$ \\
\hline 9334 & $\begin{array}{l}\text { E side of Smoky Butte Cr., } \\
14 \text { mi NW of Jordan, MT }\end{array}$ & $47.399361^{\circ},-107.182475^{\circ}$ & A.M.N.H., May 8, 1905 & $29,33,79,96,131,132$ & 9 \\
\hline 9344 & E of Point of Rocks, WY & $\begin{array}{l}41.748178^{\circ},-108.676511^{\circ} \\
{[\mathrm{NE} 1 / 4 \mathrm{SW} 1 / 4 \mathrm{Sec} .36, \mathrm{~T} .21 \mathrm{~N}} \\
\text { R. } 100 \mathrm{~W}]\end{array}$ & W.P. Revern, 1957 & 123 & 9 \\
\hline 9398 & $18.5 \mathrm{mi} \mathrm{SW}$ of Beulah, ND & \begin{tabular}{|l|}
$47.100098^{\circ},-102.117576^{\circ}$ \\
{$[S W 1 / 4$ Sec. 20, T. 142 N, R. $90 \mathrm{~W}]$} \\
\end{tabular} & & 67 & 9 \\
\hline 9402 & $\sim 5 \mathrm{mi}$ SW of Bridger, MT & $45.216793^{\circ},-108.976741^{\circ}$ & R.W. Brown, Aug. 23, 1944 & 40 & 9 \\
\hline 9403 & $\begin{array}{l}\text { N side of Hwy, } 5 \text { mi NW of } \\
\text { Rock Springs, toward Yellow- } \\
\text { stone Park, WY }\end{array}$ & $41.664233^{\circ},-109.264633^{\circ}$ & R.W. Brown, July 21, 1952 & $40 \mathrm{a}$ & 9 \\
\hline 9404 & $\sim 3 \mathrm{mi} \mathrm{W}$ of Elk Basin, WY & $44.996150^{\circ},-108.923533^{\circ}$ & R.W. Brown, Aug., 22, 1944 & $40 \mathrm{a}$ & 9 \\
\hline 9405 & $\sim 30 \mathrm{Mi} \mathrm{N}$ of Riverton, WY & $\begin{array}{l}43.451817^{\circ},-108.546450^{\circ} \\
\text { [ctr. Sec. 32, T. } 6 \text { N, R. 3 E] }\end{array}$ & $\begin{array}{l}\text { J.D. Love, W.R. Keefer \& } \\
\text { M.C. Troyer, Oct. } 1950\end{array}$ & $40 \mathrm{a}$ & 9 \\
\hline 9445 & $\begin{array}{l}\sim 1 \frac{1}{2} \text { mi NE of Whitely } \\
\text { Peak, CO }\end{array}$ & $40.322675^{\circ},-106.471906^{\circ}$ & $\begin{array}{l}\text { D. Kinney \& W. Hail, } \\
\text { Aug. } 26,1956\end{array}$ & 116 & 9 \\
\hline 9482 & Gas Hills area,WY & $\begin{array}{l}42.931052^{\circ},-107.617897^{\circ} \\
{[\mathrm{NW} 1 / 4 \mathrm{SW} 1 / 4 \mathrm{Sec} .10, \text { T. } 34 \mathrm{~N},} \\
\text { R. } 90 \mathrm{~W}]\end{array}$ & missing data & 61 & 9 \\
\hline 9492 & $\begin{array}{l}\text { W side of Hwy, } 3^{1} / 2 \text { miles } \mathrm{N} \\
\text { of Pagosa Junction, CO }\end{array}$ & $37.081261^{\circ},-107.193786^{\circ}$ & R.W. Brown, 19 June 1940 & 110 & 9 \\
\hline 9501 & $\begin{array}{l}\text { Along highway on left bank } \\
\text { of Colorado R, } 4 \text { mi SW of } \\
\text { DeBeque, } \mathrm{CO}\end{array}$ & $\begin{array}{l}39.277271^{\circ},-108.229821^{\circ} \\
{[\mathrm{NW} 1 / 4 \text { Sec. 16, T. } 9 \text { S., R. } 97 \mathrm{~W}]}\end{array}$ & missing data & $51,74,79$ & 9 \\
\hline 9532 & Sand Draw, WY & $\begin{array}{l}42.800979^{\circ},-108.183040^{\circ} \\
\text { [ctr. SW 1/4 Sec. 26, T. } 33 \mathrm{~N}, \\
\text { R. } 95 \mathrm{~W} \text { ] }\end{array}$ & W.R. Keefer & 35,121 & 9 \\
\hline 9540 & $\begin{array}{l}\text { NE of Muskrat Cr. camp at } \\
\text { cabin, on rd to Riverton, } \\
\text { WY }\end{array}$ & $43.153160^{\circ},-108.174892^{\circ *}$ & R.W. Brown 28, July 1951 & 110 & 9 \\
\hline 9544 & $\begin{array}{l}2 \mathrm{mi} \mathrm{N} \text { of Hwy 94, } 3 \mathrm{mi} \mathrm{E} \\
\text { of bridge over Jimmy Camp Cr., } \\
9 \mathrm{mi} \text { E of Colorado Springs, CO }\end{array}$ & $38.866876^{\circ},-104.605017^{\circ}$ & Missing Data & 71,81 & 9 \\
\hline 9554 & $\begin{array}{l}2 \text { mi N of hwy } 94,3 \text { mi east of } \\
\text { bridge over Jimmy Camp Cr, } 9 \\
\text { mi east of Colorado Springs, CO }\end{array}$ & $38.842058^{\circ},-104.619812^{\circ}$ & missing data & 71,81 & 9 \\
\hline 9558 & $5.5 \mathrm{mi}$ SW of Kemmerer, WY & $\begin{array}{l}41.759835^{\circ},-110.640597^{\circ} \\
\text { [ctr. of NE } 1 / 4 \sec .36, \text { T. } 21 \mathrm{~N}, \\
\text { R. } 117 \mathrm{~W} \text { ] }\end{array}$ & Missing Data & 35 & 9 \\
\hline 9565 & $\begin{array}{l}1 \text { mi above confluence of Los } \\
\text { Pinos \& San Juan Rivers, NM }\end{array}$ & $36.852992^{\circ},-106.253314^{\circ}$ & Missing Data & $45,51,132$ & 9 \\
\hline 9566 & $\begin{array}{l}3 \text { mi W of Douglas, WY, } \\
\text { just N of Hwy } 20\end{array}$ & $42.770076^{\circ},-105.422683^{\circ}$ & Missing Data & 114 & 9 \\
\hline $\begin{array}{c}\text { Woolsey } \\
522\end{array}$ & $5 \mathrm{mi}$ NW of Buckey, MT & $46.234904^{\circ},-108.538548^{\circ}$ & L.H. Woolsey & $19,104,122$ & 79 \\
\hline $\begin{array}{c}\text { Woolsey } \\
523\end{array}$ & $6 \mathrm{mi}$ NE of Buckey, MT & $46.226553,-108.344949$ & L.H. Woolsey & 96,122 & 79 \\
\hline
\end{tabular}

Coordinates marked with asterisk $\left(^{*}\right)$ are rough approximations based on limited original data. References consulted: 1. Ball \& Stebinger (1910); 2. Barnett (1914); 3. Bauer \& Herald (1921); 4. Beekly (1915); 5, 6. Bowen (1912, 1914); 7. Brant (1953); 8, 9. Brown (1939a, 1962); 10. Bryson (1952); 11. Catlett (2007); 12, 13. Collier (1919, 1925); 14. Collier \& Knechtel (1939); 15. Collier \& Smith (1908); 16. Davis (1912); 17. Dobbins (1930); 18. Dobbins \& Barnett (1928); 19, 20. Douglas (1908-1909a, b); 21. Eldridge (1896); 22. Emmons et al. (1896); 23. Freeman \& Mathers (1911); 24 Gardner (1909); 25. GEOlocate (accessed 2014); 26. Gingerich et al. (2006); 27. Goldman (1910); 28. Hares (1928); 29, 30. Hayden (1869, 1885); 31 , 32. Herald (1912, 1913); 33. Hettinger et al. (2008); 34, 35. Hewett (1914, 1926); 36. Hewett \& Lupton (1917); 37. Hickey (1977); 38. Historic MapWorks (accessed 2014); 39. Johnson (1958); 40. Johnson \& Stephens (1955); 41, 42, 43, 44, 45, 46, 47, 48, 49. Knowlton (1896, 1902, 1907, 1908, 1917, 1919, 1922, 1924, 1930); 50. Lee (1917); 51, 52. Leonard (1906, 1908); 53. Lord (1913); 54. Lloyd (1914); 55. Lupton (1909); 56. Nat. Geol. Database (accessed 2014); 57. Pal. Database (accessed 2014); 58, 59. Pepperberg (1910, 1912); 60. Pishel (1912); 61. Reeside (1924); 62, 63, 64, 65. Richardson (1910, 1911, 1915, 1917); 66. Schultz (1910); 67. Smith (1910); 68. Stone \& Calvert (1910); 69. Stone \& Lupton (1910); 70. Veatch (1907). 71, 72. Ward (1885a, b); 73. Washburne (1910); 74. Weed (1898); 75. Wegemann (1912); 76. Winchester (1912); 77. Winchester et al. (1916); 78. Woodruff (1909); 79. Woolsey et al. (1917); 80. Yen (1952). 81. Kaufmann, et al. (1990). Abbreviations: AMNH: America Museum of Natural History, Ave: Avenue, CO: Colorado, Cr.: Creek, Ctr: Center, E: East, ft: feet, Hwy: Highway, Jct: Junction, Mi: Mile(s), MT: Montana, N: North, ND: North Dakota, NE: Northeast, NM: New Mexico, NW: Northwest, PO: Post Office, R: Range, S: South, SD: South Dakota, Sec: Section, SW: Southwest, T: Township, W: West, WY: Wyoming. 